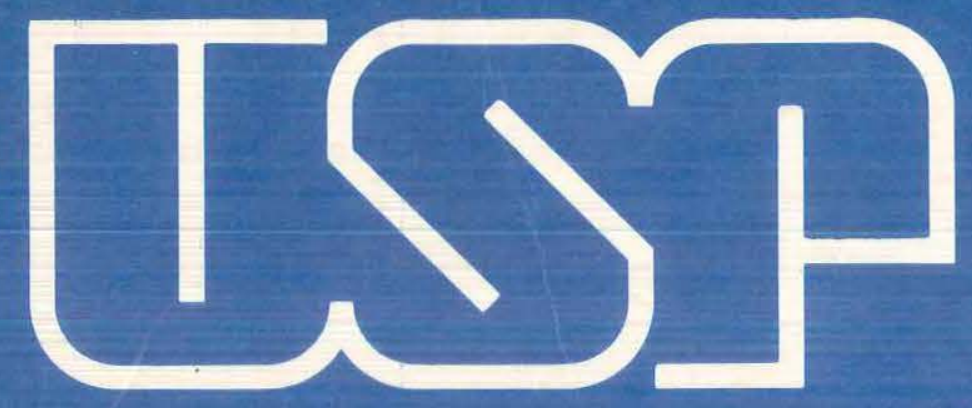

Campus de São Carlos

CARACTERIZAÇÃO DE AGREGADOS BASÁLTICOS ATRAVÉS DA ADSORÇĀO DE AZUL DE METILENO

SANDRA FABIANA RODGHER

ORIENTADOR: PROF. DR. GLAUCO TULIO PESSA FABBRI

UNIVERSIDADE DE SÃO PAULO

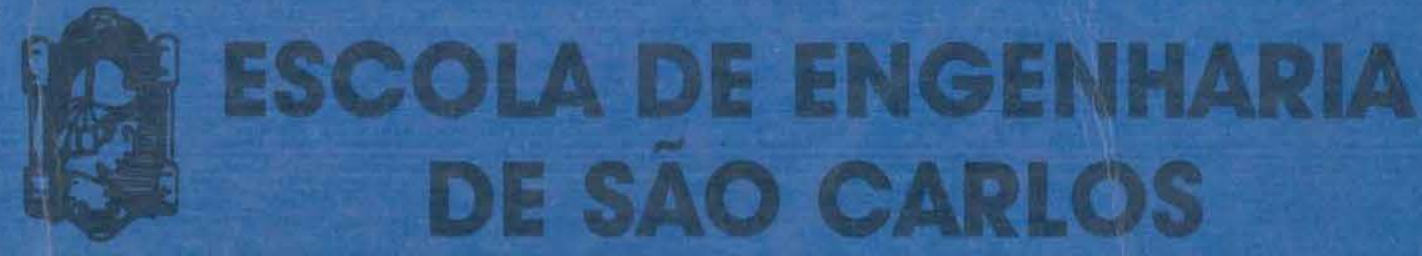




\section{CARACTERIZAÇÃO DE AGREGADOS BASÁLTICOS ATRAVÉS DA ADSORÇÃO DE AZUL DE METHLENO}

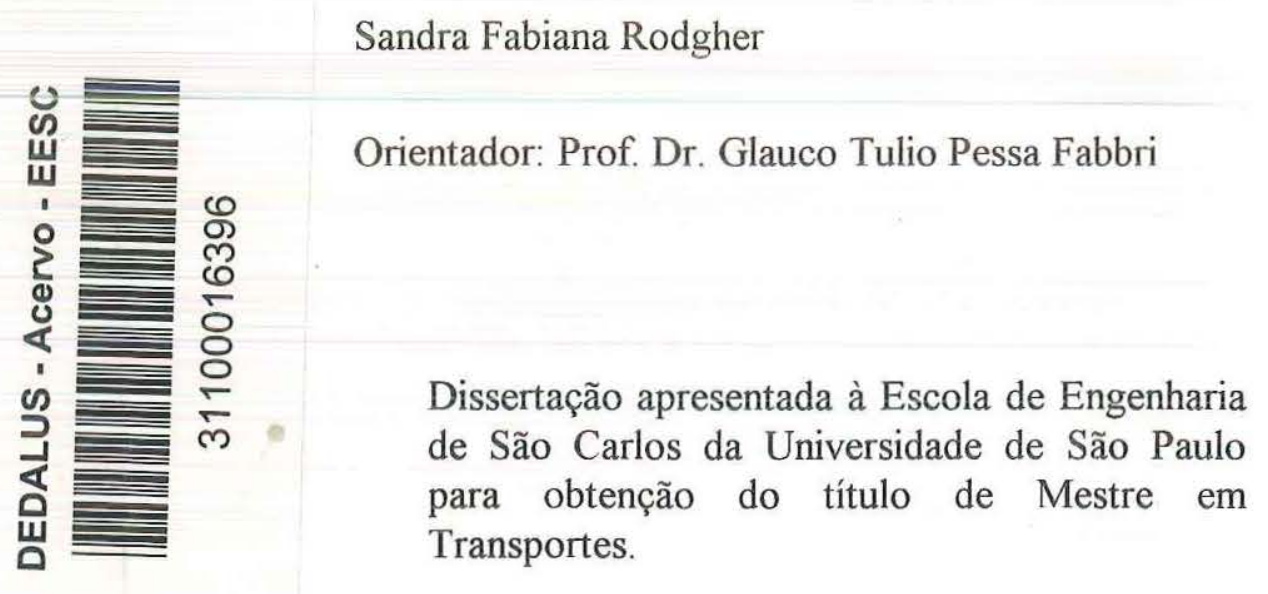

São Carlos, setembro de1996

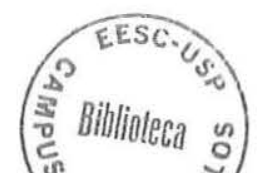


Class.

Cutt. 4884

Tombo $199 / 5$

st 0745731

Ficha catalográfica preparada pela Seção de Tratamento da Informação do Serviço de Biblioteca - EESC-USP

Rodgher, Sandra Eabiana

Caracterização de agregados basálticos através R691c da adsorcão de azul de metileno / Sandra Fabiana Rodgher. São Carlos, 1996.

Dissertacão (Mestrado) - Escola de Engenharia de São Carlos-Universidade de São Paulo, 1996.

Orientador: Prof. Dr. Glauco Tulio Pessa Fabbri

1. Azul de metileno. 2. Adsorção. 3. Agregados. I. Título 
"Os nossos sonhos acabam por se realizar, mas de um modo tal, que já não podemos reconhecê-los". 


\section{DEDICATÓRIA}

À minha família, pelo constante apoio e pela imensa alegria. 


\section{AGRADECIMENTOS}

Ao Prof. Dr. Glauco Tulio Pessa Fabbri, pela orientação efetiva e pela paciência constantes durante o desenvolvimento do trabalho;

A Diógenes Bosquetti, pelo estímulo, pelo carinho e pela compreensão dispensada nos momentos mais dificeis;

Aos professores do Departamento de Transportes da Escola de Engenharia de São Carlos da USP, em especial ao Prof. Dr. José Bernardes Félex e ao Prof. Dr. Alexandre Benetti Parreira, pelas sugestões dadas ao trabalho;

Aos técnicos do Laboratório de Estradas do STT, ao Sr. Antonio Carlos Gigante, Sr. Roberto Antonio Morasco e Sr. Antonio Carlos Oliveira pelos auxílios na coleta das amostras e na realização dos ensaios e, principalmente, pela amizade;

Aos técnicos do Laboratório de Geologia do SGS, pela ajuda prestada na realização dos ensaios;

Ao Prof. Dr. Adail R. L. Gonçalves e ao Prof. Dr. Reinaldo Lorandi da Universidade Federal de São Carlos pelas discussões que contribuíram para o desenvolvimento desta pesquisa;

Ao Prof. Dr. Lázaro Valentin Zuquette, pelo auxílio prestado durante parte do desenvolvimento desta pesquisa

À Sra. Vânia, técnica do Laboratório de Cristalografia do Departamento de Química e Física Molecular do IQSC, pelos ensaios realizados; 
Aos funcionários do Departamento de Transportes da Escola de Engenharia de São Carlos da USP, em especial à Heloisa H. M. Belo, ao Sr. Ângelo Leoni, ao Sr. Vicente Rafael Daló e ao Sr. Carlos Mariano;

Às Pedreiras Bandeirantes, Santo Antonio, Ouro Fino e Multipedras pela gentileza em cederem as amostras de rocha;

Ao Eng. Sebastião Brito Fernandes, da Prefeitura de Araraquara, pelo apoio na coleta de amostras nas pedreiras pertencentes ao município de Araraquara;

Aos meus amigos Sandra Oda, Sandra Aparecida Margarido, Vânia Maria Pessôa Pampolha, Suelly Helena de A. Barroso, Roberto T. Aramaki, Jairo Salim Pinheiro de Lima e Alexandre Cagnani Foretti. 


\section{RESUMO}

Este trabalho apresenta uma avaliação do ensaio de adsorção de azul de metileno pelo método da mancha para qualificar agregados basálticos. Analisa-se, também, outros ensaios, tais como ensaios analíticos, ensaios fisico-mecânicos, ensaios de adesividade e ensaios de alteração, abordando aspectos relacionados à validade e representatividade dos resultados destes na caracterização de agregados basálticos.

Foram estudadas nove amostras de agregados basálticos (quatro sãs e cinco alteradas), originárias de afloramentos existentes em três municípios do interior do estado de São Paulo.

Conclui-se que o ensaio de adsorção de azul de metileno pelo método da mancha é promissor para a deteç̧ão da alteração de agregados basálticos e que alguns dos ensaios rotineiros não são capazes de distinguir materiais sãos dos alterados, fatos estes observados mediante um estudo comparativo entre o ensaio de adsorção de azul de metileno pelo método da mancha e os outros ensaios. 


\section{ABSTRACT}

An estimative of methylene blue adsorption analysis is used to quality basaltic aggregates. It is also analysed others tests like: analytic, physical-mechanics, adhesiveness and alteration tests showing aspects related to the validity and representativeness of the results of these tests for the basaltic aggregation caracterization

In this work it is studied nine samples of basaltic aggregations (four considered good and five changed) extracted from stone-quarries located in three different cities in the state of São Paulo.

It is conclued that the methylene blue adsorption test can be promising in detecting the alterability of basaltic samples and also that some routine tests are not able to distinguish good materials from the changed ones. These facts were observed from a comparative study among methylene blue test and other tests. 


\section{LISTA DE FIGURAS}

Figura 2.1 - Esquema de seqüência de conversões químicas do azul de metileno, segundo SHREVE \& BRINK (1980).

Figura 2.2 - Variação da adsorção de azul de metileno em função do pH da suspensão para quatro caulinitas, segundo FARUQI et alii (1967).

Figura 2.3 - Capacidade de troca catiônica versus superficie especifica, segundo PHELPS \& HARRIS (1970).

Figura 2.4 - Capacidade de troca catiônica versus módulo de ruptura de misturas argilosas, segundo PHELPS \& HARRIS (1970).

Figura 2.5 - Variação do consumo de azul de metileno em função da quantidade e do tipo de argila nas misturas, segundo LAN (1980).

Figura 2.6 - Variação da adsorção de azul de metileno em função da composição granulométrica das argilas, segundo LAUTRIN (1987).

Figura 2.7 - Comparação da capacidade de troca catiônica obtida pelo método do Instituto Agronômico de Campinas e pelo ensaio de ad́sorção de azul de metileno pelo método da mancha, segundo PEJON (1992).

Figura 4.1 - Equipamento utilizado no ensaio de alteração por lixiviação contínua com o extrator "Soxhlet". 
Figura 4.2 - Esquema do equipamento para o ensaio de alteração por lixiviação contínua com extrator "Soxhlet" (Figura sem dimensões).

Figura 4.3 - Fluxograma do ensaio de adsorção de azul de metileno pelo método da mancha.

Figura 5.1 - Valores da densidade real de agregado miúdo.

Figura 5.2 - Valores de Desgaste de agregado por abrasão "Los Angeles" e o valor máximo recomendado, segundo DER-SP (1991).

Figura 5.3 - Valores de do índice de tenacidade Treton e o valor máximo recomendado, segundo FRAZÃO (1987).

Figura 5.4 - Valores das perdas do agregado ao esmagamento e o valor máximo recomendado, segundo MACEDO et alii (1988).

Figura 5.5 - Valores de resistência mecânica de agregado pelo método dos $10 \%$ de finos e o valor máximo recomendado, segundo MACEDO et alii (1988).

Figura 5.6 - Valores de desgaste de agregado por abrasão "Los Angeles" após o ensaio de alteração por lixiviação contínua para 0,10 e 40 ciclos.

Figura 5.7 - Valores dos indices de proporções de metais alcalinos e alcalino-terrosos (I), para 10 e 40 ciclos.

Figura 5.8 - Valores de Avaliação da durabilidade de agregados pelo emprego de soluções de sulfato de sódio e o valor máximo recomendado, segundo DER-SP (1991).

Figura 5.9 - Valores de azul de metileno (Va).

Figura 5.10 - Valor de azul (Va) versus "área" aproximada da "fração fina" da rocha. 
Figura 5.11 - Valores de azul versus valores de desgaste de agregado por abrasão "Los Angeles".

Figura 5.12 - Valores de azul versus valores do índice de tenacidade Treton.

Figura 5.13 - Valores de azul versus valores do perdas de agregado ao esmagamento.

Figura 5.14 - Valores de azul versus valores da carga para a produção de $10 \%$ de finos.

Figura 5.15 - Valores de azul versus valores de avaliação da durabilidade de agregados pelo emprego de soluções de sulfato de sódio.

Figura 5.16 - Valores de desgaste de agregado por abrasão "Los Angeles" versus valores do índice de tenacidade Treton.

Figura 5.17 - Valores de desgaste de agregado por abrasão "Los Angeles" versus valores do ensaio de esmagamento.

Figura 5.18 - Valores de desgaste de agregado por abrasão "Los Angeles" versus valores de avaliação da resistência mecânica de agregado pelo método dos $10 \%$ de finos.

Figura 5.19 - Valores de desgaste de agregado por abrasão "Los Angeles" versus valores de avaliação da durabilidade de agregados pelo emprego de soluções de sulfato de sódio.

Figura 5.20 - Valores do índice de tenacidade Treton versus valores de perda do agregado ao esmagamento.

Figura 5.21 - Valores do índice de tenacidade Treton versus valores de avaliação da resistência mecânica de agregados pelo método dos $10 \%$ de finos.

Figura 5.22 - Valores do índice de tenacidade Treton versus valores de avaliação da durabilidade de agregados pelo emprego de soluções de sulfato de sódio. 
Figura 5.23 - Valores do ensaio de esmagamento versus valores de avaliação da resistência mecânica de agregados pelo método dos $10 \%$ de finos.

Figura 5.24-Valores do ensaio de esmagamento versus valores de avaliação da durabilidade de agregados pelo emprego de soluções de sulfato de sódio.

Figura 5.25 - Valores avaliação da resistência mecânica de agregados pelo método dos $10 \%$ de finos versus valores de avaliação da durabilidade de agregados pelo emprego de soluções de sulfato de sódio. 


\section{LISTA DE QUADROS}

Quadro 2.1 - Valores encontrados para a área da molécula de azul de metileno, segundo KIPLING \& WILSON (1960).

Quadro 2.2 - Capacidade de troca catiônica de vários argilo-minerais, obtidos pela adsorção de azul de metileno e pelo método do acetato de amônio, segundo NEVINS \& WEINTRITT (1967).

Quadro 2.3 - Valores apresentados na literatura para capacidade de troca catiônica, segundo NEVINS \& WEINTRITT (1967).

Quadro 2.4 - Superficie específica de argilo-minerais obtidas pelo ensaio de adsorção de azul de metileno pelo método da mancha, segundo LCPC (1979).

Quadro 2.5 - Superficie Especifica das argilas, segundo DENNIS et alii (1980).

Quadro 2.6 - Adsorção de azul de metileno versus estados de alterações de rochas magmáticas, segundo DENNIS et alii (1980).

Quadro 2.7 - Comparação entre propriedades geotécnicas e valor de azul de certas rochas, segundo DENNIS et alii (1980).

Quadro 2.8 - Composições das frações das argilas utilizadas por LAUTRIN (1987).

Quadro 2.9 - Valores de adsorção de azul de metileno relatados por SAMESHIMA (1990) et alii segundo HIGGS (1988).

Quadro 3.1 - Procedência e localização das amostras coletadas. 
Quadro 3.2 - Relação das faixas granulométricas e quantidades de material utilizadas na fase experimental.

Quadro 3.3 - Identificação das amostras ensaiadas.

Quadro 4.1 - Roteiro para avaliação preliminar do estado de alteração e do grau de coerência de rochas, segundo FRAZÃO \& AUGUSTO (1994).

Quadro 5.1 - Descrição das características macroscópicas e microscópicas e avaliação preliminar do estado de alteração e do grau de coerência de rochas.

Quadro 5.2 - Resultados de densidade real de agregado miúdo (método do picnômetro) e dos ensaios físico-mecânicos.

Quadro 5.3 - Resultados dos ensaios de adesividade de agregado graúdo a ligante betuminoso e estimativa do grau de descolamento da película betuminosa.

Quadro 5.4 - Resultados do ensaio de adesividade de agregado miúdo a ligante betuminoso.

Quadro 5.5 - Resultados dos ensaios de alteração por lixiviação contínua com extrator "Soxhlet" para 10 e 40 ciclos conjugado com desgaste de agregado por abrasão "Los Angeles".

Quadro 5.6-Análise química da água utilizada no ensaio de lixiviação contínua com extrator "Soxhlet".

Quadro 5.7 - Índice de proporções de metais alcalinos e alcalino-terrosos (I).

Quadro 5.8 - Resultados do ensaio de avaliação da durabilidade de agregados pelo emprego de soluções de sulfato de sódio.

Quadro 5.9 - Resultados do ensaio de adsorção de azul de metileno pelo método da mancha. 
Quadro 5.10 - Posições das amostras em relação a cada ensaio.

Quadro 6.1 - Relação entre o consumo de azul de metileno entre os pares de rochas de mesmo local de origem. 


\section{ÍNDICE}

DEDICATÓRIA ii

AGRADECIMENTOS iii

RESUMO V V U V V V V

ABSTRACT vi

LISTA DE FIGURAS vii

LISTA DE QUADROS Xi

CAPÍTULO 1: INTRODUÇÃO 1

CAPÍTULO 2: A UTILIZAÇÃO DO AZUL DE METILENO 4

2.1. Introdução 4

2.2. Utilização do Ensaio de Adsorção de Azul de Metileno pelo Método da $\begin{array}{ll}\text { Mancha na Caracterização de Solos e Rochas } & 6\end{array}$

CAPÍTULO 3: AMOSTRAS ESTUDADAS 27

3.1. Introdução

3.2. Localização e Características Geológicas das Amostras 28

3.3. Coleta e Preparação das Amostras. 29

CAPÍTULO 4: PROGRAMA DE ENSAIOS 32 
4.1. Introdução 32

4.2. Determinações Analíticas 33

4.2.1. Difratometria de Raios X 33

4.2.2. Análise Petrográfica Macroscópica 34

4.2.3. Análise Petrográfica Microscópica 36

4.3. Determinações Complementares 36

4.3.1. Densidade Real de Agregado Miúdo - Método do Picnômetro

4.3.2. Análise Granulométrica por Sedimentação-Método do Densímetro

4.4.1. Desgaste de Agregado por Abrasão "Los Angeles"

4.4.2. Determinação do Índice de Tenacidade de Agregados pelo Aparelho Treton

4.4.3. Ensaio de Esmagamento

4.4.4. Avaliação da Resistência Mecânica de Agregados pelo Método dos $10 \%$ de Finos

4.5. Adesividade de Agregado a Ligante Betuminoso

4.5.1. Adesividade de Agregado Graúdo a Ligante Betuminoso

4.5.2. Adesividade de Agregado Miúdo a Ligante Betuminoso 
4.6.1. Ensaio de Alteração por Lixiviação Contínua com Extrator "Soxhlet" conjugado com Desgaste de Agregado por Abrasão "Los Angeles"

4.6.2. Avaliação da Durabilidade de Agregados pelo Emprego de Soluções de Sulfato de Sódio ou de Magnésio

4.7. Ensaio de Adsorção de Azul de Metileno pelo Método da Mancha

4.7.1. Aparelhagem e Materiais

4.7.3 Execução do Ensaio

4.7.4 Resultados

CAPÍTULO 5: APRESENTAÇ̃̃O E DISCUSSÃO DOS RESULTADOS DA PESQUISA

5.1. Introdução

5.2.1. Difratometria de Raios $X$

5.2.2. Análises Petrográficas Macroscópicas

5.2.3. Análises Petrográficas Microscópicas 
5.3.3. Determinação do Índice de Tenacidade de Agregados pelo Aparelho Treton

5.3.4. Ensaio de Esmagamento

5.3.5. Avaliação da Resistência Mecânica de Agregados pelo Método dos $10 \%$ de Finos

5.4.1. Ensaio de Adesividade de Agregado Graúdo a Ligante Betuminoso

5.4.2. Ensaio de Adesividade de Agregado Miúdo a Ligante Betuminoso

5.5.1. Alteração por Lixiviação Contínua com Extrator "Soxhlet" conjugado com Desgaste de Agregado por Abrasão "Los Angeles"

5.5.2. Avaliação da Durabilidade de Agregados pelo Emprego de Soluções de Sulfato de Sódio

5.7. Discussão dos Resultados do Ensaio de Adsorção de Azul de Metileno pelo Método da Mancha versus Outros Ensaios 
5.8.1. Desgaste de Agregado por Abrasão "Los Angeles" versus Outros Ensaios

5.8.2. Determinação do Índice de Tenacidade de Agregados pelo Aparelho Treton Versus Outros Ensaios

6.2.1. Quanto ao Ensaio de Adsorção de Azul de Metileno pelo Método da Mancha 
ANEXO III: MÉTODO DE CÁlCULO DA "ÁREA" APROXIMADA DAS AMOSTRAS E OS RESULTADOS DOS ENSAIOS DE ANÁLISE GRANULOMÉTRICA POR SEDIMENTAÇ̃̃O

ANEXO IV: FOTOS DOS RESULTADOS DO ENSAIO DE ADESIVIDADE DE AGREGADO GRAÚDO A LIGANTE BETUMINOSO 


\section{CAPÍTULO 1: INTTRODUÇÃO}

Os agregados pétreos, para fins de utilização em engenharia civil, devem apresentar certas características mínimas de qualidade, notadamente para uso em pavimentação. Existem, para fins de caracterização dos materiais pétreos, inúmeros ensaios de laboratório que procuram estabelecer a qualidade dos agregados em função da sua utilização. Na escolha destes ensaios é importante avaliar a sua aplicabilidade e a validade dos índices fornecidos para a previsão do comportamento dos materiais quando em serviço.

É evidente que não é possível estabelecer qual ou quais ensaios seriam considerados adequados para a utilização em pavimentação. O que se pretende é avaliar o comportamento de cada ensaio frente a um mesmo conjunto de amostras.

Neste trabalho é realizada uma avaliação do ensaio de adsorção de azul de metileno pelo método da mancha para a caracterização de agregados basálticos, assim como de outros ensaios mais conhecidos no meio técnico, tais como desgaste de agregado por abrasão "Los Angeles", determinação do índice de tenacidade de agregados pelo aparelho Treton, esmagamento etc. Para isto foram coletadas nove amostras (quatro comercializadas e cinco alteradas) de cinco pedreiras do interior do estado de São Paulo.

O ensaio de adsorção de azul de metileno pelo método da mancha vem sendo utilizado com sucesso na França (Laboratoires des Ponts et Chaussées) por inúmeros pesquisadores, visando a classificação de solos e rochas. Esta dissertação baseou-se nas idéias lançadas por DENNIS et alii (1980) e HIGGS (1988), que o utilizaram para a caracterização de rochas. 
O princípio deste ensaio fundamenta-se no fato de que o azul de metileno é uma molécula polar que, quando em solução aquosa e em contato com materiais pétreos ou solos, é adsorvido à superficie destes materiais devido à atração elétrica. Assim, ele é capaz de avaliar, nos agregados pétreos, a presença de materiais deletérios (argilo-minerais) ou ainda detectar a presença de microfissuramentos, uma vez que a quantidade de corante consumida no ensaio é proporcional à superficie especifica do material analisado.

Neste trabalho foi utilizado o ensaio de adsorção de azul de metileno pelo método da mancha adaptado por FABBRI (1994), que consiste, simplificadamente, na determinação, por titulação, da quantidade de azul de metileno consumida por grama de rocha pulverizada.

Além do ensaio de adsorção de azul de metileno pelo método da mancha, foram utilizados os seguintes ensaios: desgaste de agregado por abrasão "Los Angeles", determinação do índice de tenacidade de agregados pelo aparelho Treton, esmagamento, avaliação da resistência mecânica de agregados pelo método dos $10 \%$ de finos, adesividade de agregado graúdo a ligante betuminoso, adesividade de agregado miúdo a ligante betuminoso, avaliação da durabilidade de agregados pelo emprego de soluções de sulfato de sódio $\left(\mathrm{Na}_{2} \mathrm{SO}_{4}\right)$ ou de magnésio $\left(\mathrm{MgSO}_{4}\right)$ e lixiviação contínua com extrator "Soxhlet" conjugado com desgaste de agregado por abrasão "Los Angeles".

Esta dissertação está organizada em seis Capítulos e quatro Anexos, que têm os seguintes conteúdo:

No Capítulo 2 é realizada uma revisão bibliográfica sobre a utilização da adsorção do azul de metileno $\left(\mathrm{C}_{16} \mathrm{H}_{18} \mathrm{~N}_{3} \mathrm{SCl}\right)$ em diversas áreas do conhecimento humano, desde a medicina, farmacologia e indústria têxtil, até sua contribuição para a caracterização de materiais, tanto para uso em indústrias cerâmicas como para a classificação de solos e rochas. São citados trabalhos de diversos pesquisadores que trabalharam nesta área, 
bem como as principais conclusões e os índices propostos para a classificação de solos e rochas.

O Capítulo 3 é reservado à descrição, à localização e às características geológicas das amostras que foram estudadas. Por fim, descreve-se o processo de coleta e transporte das amostras, bem como os métodos e nomenclatura adotados e utilizados na execução dos ensaios.

No Capítulo 4 são descritos os métodos de ensaios de laboratório utilizados, que forneceram indícios quanto à qualidade dos agregados pétreos estudados. Neste capítulo os ensaios foram agrupados em cinco grupos, a saber: ensaios analíticos, físico-mecânicos, de alteração, de adesividade e de adsorção de azul de metileno pelo método da mancha.

No Capítulo 5 são apresentados e discutidos os resultados da pesquisa, seguindo a ordem de apresentação utilizada no capítulo anterior. Inicialmente faz-se uma discussão individual de cada ensaio, avaliando a correspondência e aplicabilidade dos resultados obtidos com os valores recomendados na literatura. Em seqüência, são efetuados confrontos entre ensaio de adsorção de azul de metileno pelo método da mancha e os outros ensaios e, posteriormente faz-se o confronto dos outros ensaios entre si.

No Capítulo 6 são apresentadas as principais conclusões desta pesquisa, que são divididas quanto ao ensaio de adsorção de azul de metileno pelo método da mancha e quanto aos outros ensaios utilizados.

Os Anexos I, II, III e IV contêm, respectivamente, as fotos dos locais de coleta das amostras, a interpretação dos ensaios de difratometria de raios $\mathrm{X}$, o método de cálculo da "área" aproximada das amostras e os resultados dos ensaios de análise granulométrica por sedimentação e as fotos dos resultados do ensaio de adesividade de agregado graúdo a ligante betuminoso. 


\section{CAPÍTULO 2: A UTILIZAÇÃO DO AZUL DE METILENO}

\subsection{INTRODUÇÃO}

O azul de metileno é um corante orgânico iônico, que origina-se a partir da dimetilanilina, como mostra a Figura 2.1. Atualmente este composto iônico recebe o nome científico de cloreto de tetrametildiaminodifenaztiônio $\left(\mathrm{C}_{16} \mathrm{H}_{18} \mathrm{~N}_{3} \mathrm{SCL}\right)$, possuindo peso molecular 319,9, cor azul Básico nº 9 e a classificação CI 52015, segundo o "Merck Index". Uma vez hidratado, seu peso molecular aumenta para 373,9 , com a inclusão de três moléculas de água $\left(\mathrm{C}_{16} \mathrm{H}_{18} \mathrm{~N}_{3} \mathrm{SCL} .3 \mathrm{H}_{2} \mathrm{O}\right)$.

Caracteriza-se como um corante catiônico, ou seja, em solução aquosa apresenta-se dissociado em ânions cloreto (CL) e cátions azul de metileno $\left(\mathrm{C}_{16} \mathrm{H}_{18} \mathrm{~N}_{3} \mathrm{~S}^{+}\right)$, e colocado em contato com materiais negativamente carregados, suas moléculas são rapidamente adsorvidas mediante um mecanismo de troca iônica irreversível (adsorção).

Segundo CASANOVA (1986), dado o tamanho do cátion azul de metileno, a velocidade de troca ou de adsorção decresce à medida que as posições de troca vão sendo preenchidas. Contudo, ao final do processo a troca é total e cada molécula de azul de metileno ocupa uma área de $132 \AA^{2}$. Sabendo-se isso e mais a quantidade que foi adsorvida pode-se calcular a capacidade de troca cationica (CTC) e a superficie específica (SE) do material analisado. 

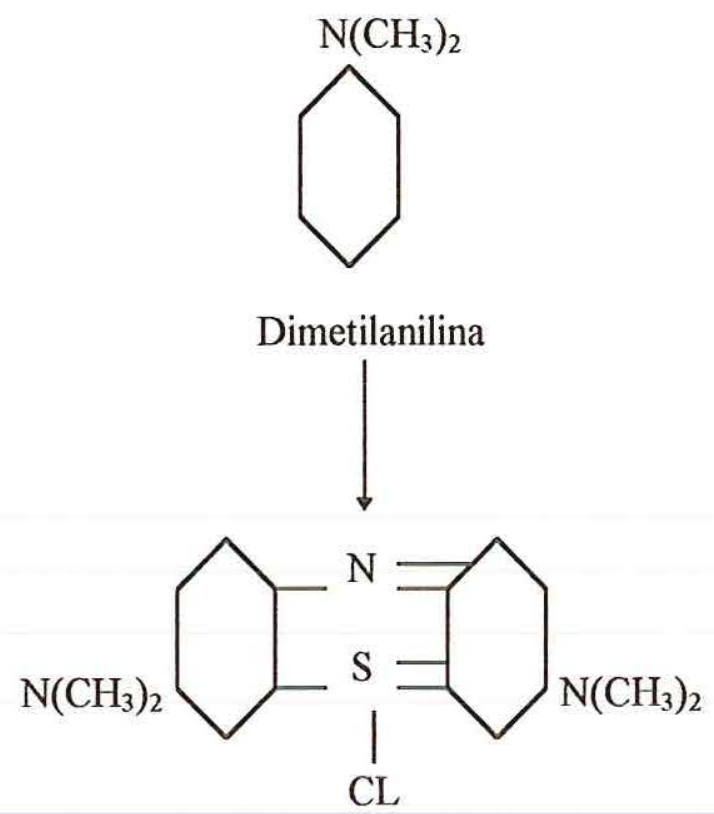

Figura 2.1 - Esquema de seqüência de conversões químicas do azul de metileno, segundo SHREVE \& BRINK (1980).

O azul de metileno, devido ao mecanismo de adsorção que ocorre quando há a incorporação de uma camada de azul de metileno sobre à superfície de outra substância, é amplamente empregado na medicina e veterinária como antisséptico e antídoto para envenenamento por cianeto e nitrato.

Na farmacologia é útil como pigmento biológico (teste no leite para detectar infeção tubercular, tingimento de bacilos de Koch em tecido de mamífero, corar fibras elásticas e tecido conectivo) e para o tratamento de amigdalites ou faringites agudas via oral. Na indústria química é utilizado como indicador nas reações de oxi-redução, com solução aquosa para determinação fotométrica por extração dos elementos: B, $\mathrm{Sb}, \mathrm{Ga}$, In, Pd, Os, Ta. Já na indústria têxtil, para o tingimento de materiais, como juta, linho, seda, lã, couro e papel. 


\subsection{UTILIZAÇÃO DO ENSAIO DE ADSORÇÃO DE AZUL DE METILENO PELO MÉTODO DA MANCHA NA CARACTERIZAÇÃO DE SOLOS E ROCHAS.}

A utilização de corantes para determinação de superficie específica (SE) e capacidade de troca catiônica (CTC) dos solos, segundo CHEN et alii (1974), iniciou-se com PANETH que, em 1924, testou o uso de corantes para a determinação de superfície específica de sais de chumbo, concluindo que havia a formação de uma camada monomolecular quase que completa de moléculas de azul de metileno adsorvidas. sobre as faces dos sais.

MITCHELL et alii (1955) utilizaram o azul de metileno em areias quartzosas, concluindo que as areias recobertas artificialmente com óxidos de ferro $\left(\mathrm{F}_{2} \mathrm{O}_{3}\right)$ ou cromo $\left(\mathrm{Cr}_{2} \mathrm{O}_{3}\right)$ adsorviam menor quantidade do corantes e que o $\mathrm{pH}$ da solução influenciava a quantidade de corante adsorvida.

KIPLING \& WILSON (1960) utilizaram o azul de metileno em esferas de carbono não porosas para determinação da área da molécula do corante e obtiveram os valores apresentados pelo Quadro 2.1. Concluíram que o ensaio de adsorção de azul de metileno pelo método da mancha não fornece resultados precisos para a determinação da superficie específica de materiais compostos de carbono.

NEVINS \& WEINTRITT (1967) discutiram o uso do ensaio de azul de metileno pelo método da mancha para a determinação da capacidade de troca catiônica (CTC) de várias bentonitas e argilas utilizadas em cerâmicas e estes resultados foram comparados com os obtidos do método do acetato de amônio $\left(\mathrm{NH}_{4} \mathrm{C}_{2} \mathrm{H}_{3} \mathrm{O}_{2}\right)$.

Estes autores utilizaram o ensaio de adsorção de azul de metileno pelo método da mancha desenvolvido por JONES (1964), que consiste, basicamente, da titulação de uma suspensão de solo mais água com uma solução de azul de metileno padronizada, em meio intensamente agitado; após a adição de uma certa quantidade de corante, 
retira-se uma gota da solução (corante + água + solo), que é pingada sobre o papel de filtro. Se a mancha formada pela difusão da gota no papel apresentar uma áura azul clara ou esverdeada, significa que há excesso de corante na solução, senão, adicionase mais corante e repete-se o teste da mancha até atingir o ponto onde há excesso de corante, designado como ponto de viragem. $\mathrm{O}$ ensaio de adsorção de azul de metileno pelo método da mancha será descrito com maiores detalhes no Capítulo 4.

Quadro 2.1 - Valores encontrados para a área da molécula de azul de metileno, segundo KIPLING \& WILSON (1960).

\begin{tabular}{|c|c|c|c|}
\hline \multirow{2}{*}{ Amostras } & $\begin{array}{c}\text { Temperatura } \\
\left({ }^{\circ} \mathbf{C}\right)\end{array}$ & $\begin{array}{c}\text { Adsorção máxima } \\
(\mathbf{m g} / \mathbf{g})\end{array}$ & $\begin{array}{c}\text { Área da molécula de azul de } \\
\text { metileno }\left(\mathbf{\AA}^{2}\right)\end{array}$ \\
\hline \multirow{2}{*}{ Spheron 6 } & 20 & 63 & 102 \\
\cline { 2 - 4 } & 80 & 68 & 94 \\
\hline \multirow{2}{*}{ Grafite } & 20 & 59 & 108 \\
\cline { 2 - 4 } & 80 & 64 & 100 \\
\hline
\end{tabular}

No Quadro 2.2 são apresentadas as capacidades de troca catiônica de diversos argilominerais, obtidas por NEVINS \& WEINTRITT (1967), pelos ensaios de adsorção de azul de metileno pelo método da mancha e de acetado de amônio.

Já no Quadro 2.3 são apresentados as capacidades de troca catiônica comumente encontradas na literatura, segundo NEVINS \& WEINTRITT (1967), para alguns argilo-minerais. 
Quadro 2.2 - Capacidade de troca catiônica de vários argilo-minerais, obtidas pela adsorção de azul de metileno e pelo método do acetato de amônio, segundo NEVINS \& WEINTRITT (1967).

\begin{tabular}{|c|c|c|}
\hline Amostras & $\begin{array}{c}\text { Ensaio de adsorcão de azul } \\
\text { de metileno pelo método } \\
\text { da mancha } \\
\text { CTC (meq/100 g) }\end{array}$ & $\begin{array}{c}\text { Ensaio de acetato } \\
\text { de amônio }\end{array}$ \\
\hline CTC (meq/100 g) \\
\hline EG 28 BentonitaWyoming & 76,6 & 77,5 \\
\hline EG 20 BentonitaWyoming & 74,5 & 74,9 \\
\hline MI 19 Bentonita Centrifugada & 77,8 & 81,9 \\
\hline EG 16 Bentonita inferior & 101,0 & 91,9 \\
\hline EG 24 Bentonita inferior & 71,8 & 76,4 \\
\hline EG 21 Bentonita Texas & 69,2 & 73,2 \\
\hline EG 21 Bentonita Texas tratada & 62,2 & 65,5 \\
\hline NE 93 Hectorita Centrifugada & 85,2 & 83,3 \\
\hline BI 52 Atapulgita & 117,0 & 85,5 \\
\hline NE 96 Argila nativa & 25,7 & 22,3 \\
\hline
\end{tabular}

Unidade de capacidade de troca catiônica (CTC) dada em miliequivalente por $100 \mathrm{~g}$ de argila.

Ainda, segundo NEVINS \& WEINTRITT (1967), os resultados apresentados mostraram que o método de adsorção de azul de metileno pelo método da mancha forneceu valores próximos aos determinados pelo método de acetato de amônio, sendo que as diferenças foram comumente menores que 5,0 meq/100 g, indicando ser um método prático, com alto grau de reprodutibilidade, precisão e rapidez. 
Quadro 2.3 - Valores apresentados na literatura para capacidade de troca catiônica, segundo NEVINS \& WEINTRITT (1967).

\begin{tabular}{|c|c|}
\hline Amostras & Limite (meq/100 g) \\
\hline Montmorilonita & $80-150$ \\
\hline Vermiculita & $100-150$ \\
\hline Halosita $-4 \mathrm{H}_{2} \mathrm{O}$ & $10-40$ \\
\hline Ilita & $10-40$ \\
\hline Clorita & $10-40$ \\
\hline Sepiolita - Atapulgita & $20-30$ \\
\hline Halosita - $2 \mathrm{H}_{2} \mathrm{O}$ & $5-10$ \\
\hline Caulinita & $3-15$ \\
\hline
\end{tabular}

FARUQI et alii (1967) estudaram a adsorção do azul de metileno para quatro amostras de caulinita, variando o pH da suspensão água + argila.

Na Figura 2.2 são apresentados os resultados obtidos por estes autores. Em abcissas está representado o pH da suspensão utilizada no ensaio e em ordenadas, a adsorção do corante azul de metileno. Através dessa pesquisa, FARUQI et alii (1967) concluíram que, quanto maior o pH da suspensão água + argila, maior a adsorção de azul de metileno. 


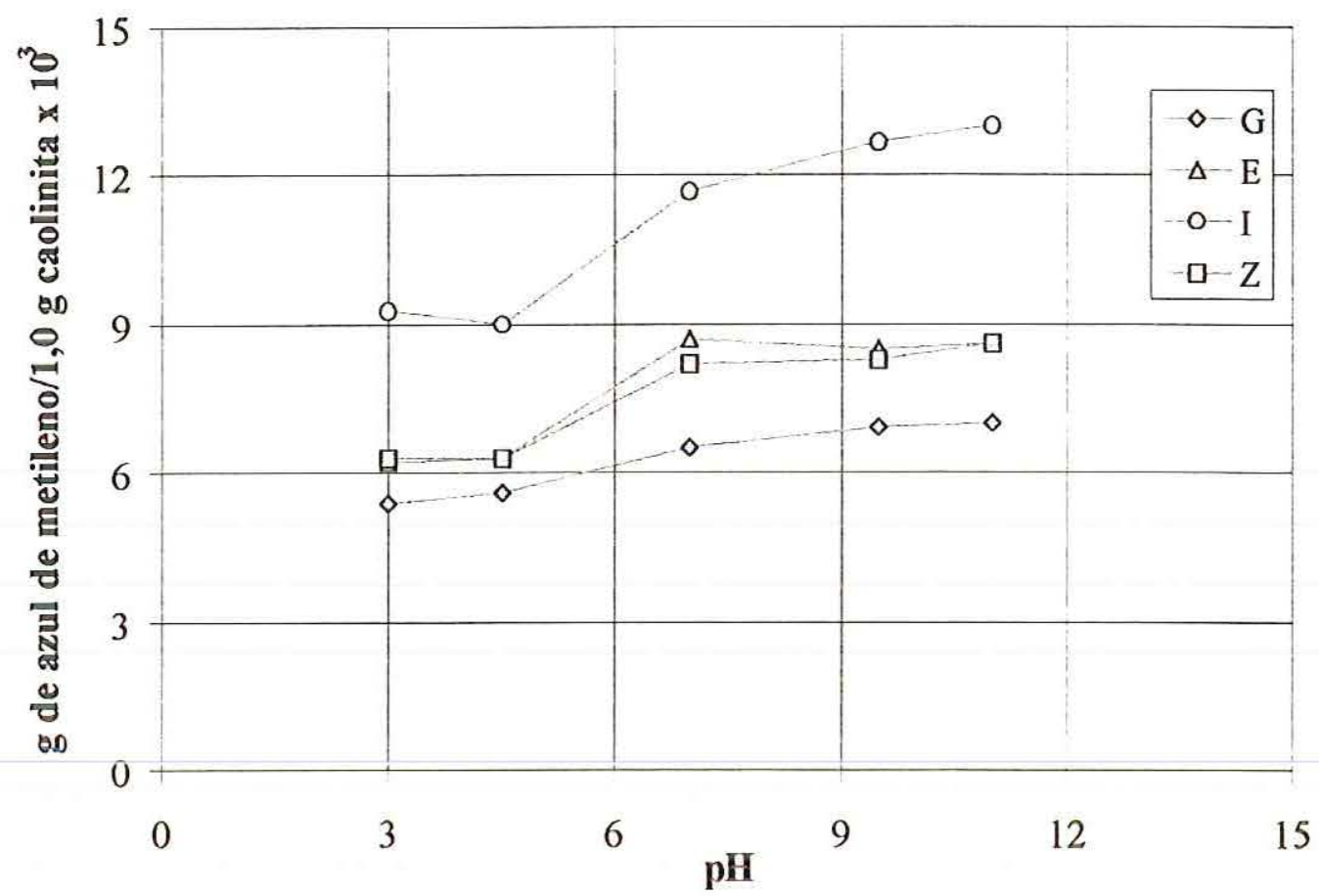

Figura 2.2 - Variação da adsorção de azul de metileno em função do pH da suspensão para quatro caulinitas, segundo FARUQI et alii (1967).

PHELPS \& HARRIS (1968) correlacionaram os resultados da superficie específica (SE), determinada pela adsorção de azul de metileno pelo método da mancha, com a capacidade de troca catiônica (pelo método do acetato de amônio) e da capacidade de troca catiônica, determinada pela adsorção de azul de metileno, com o módulo de ruptura de argilas utilizadas para cerâmica, conforme mostrado nas Figuras 2.3 e 2.4 .

A Figura 2.3 mostra a variação da capacidade de troca catiônica em função da superficie específica, obtida do ensaio de azul de metileno pelo método da mancha, para vinte e nove argilas. A relação é direta e apresenta um coeficiente de correlação de 0,926 . 


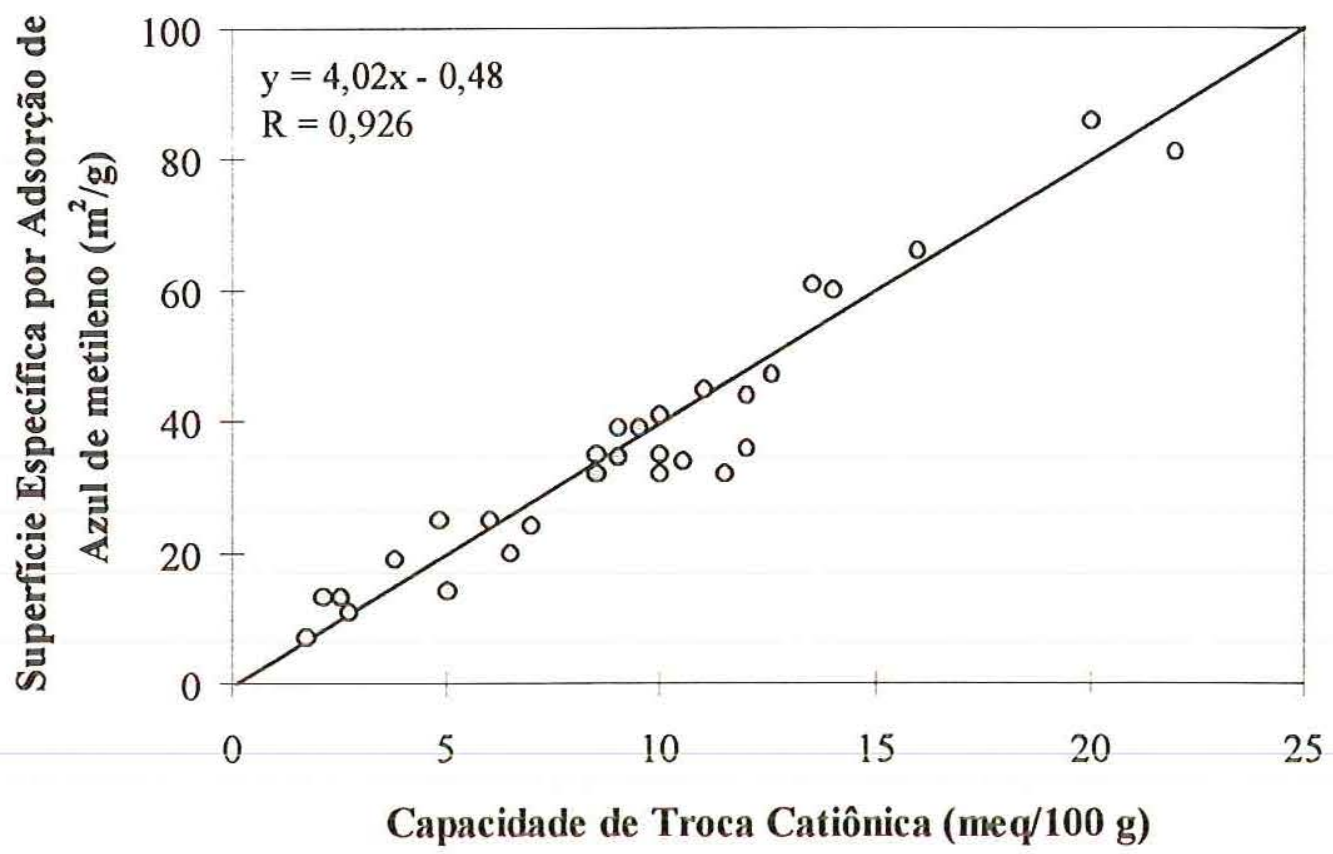

Figura 2.3 - Capacidade de troca cationica versus superfície específica, segundo PHELPS \& HARRIS (1970).

Na Figura 2.4 são apresentados os resultados da capacidade de troca cationica, através do ensaio de azul de metileno pelo método da mancha versus o módulo de ruptura de misturas argilosas. A relação é direta e apresenta um coeficiente de correlação de 0,847 . Os resultados permitiram prever o módulo de ruptura das argilas a partir da capacidade de troca catiônica determinada com o ensaio de azul de metileno pelo método da mancha. 


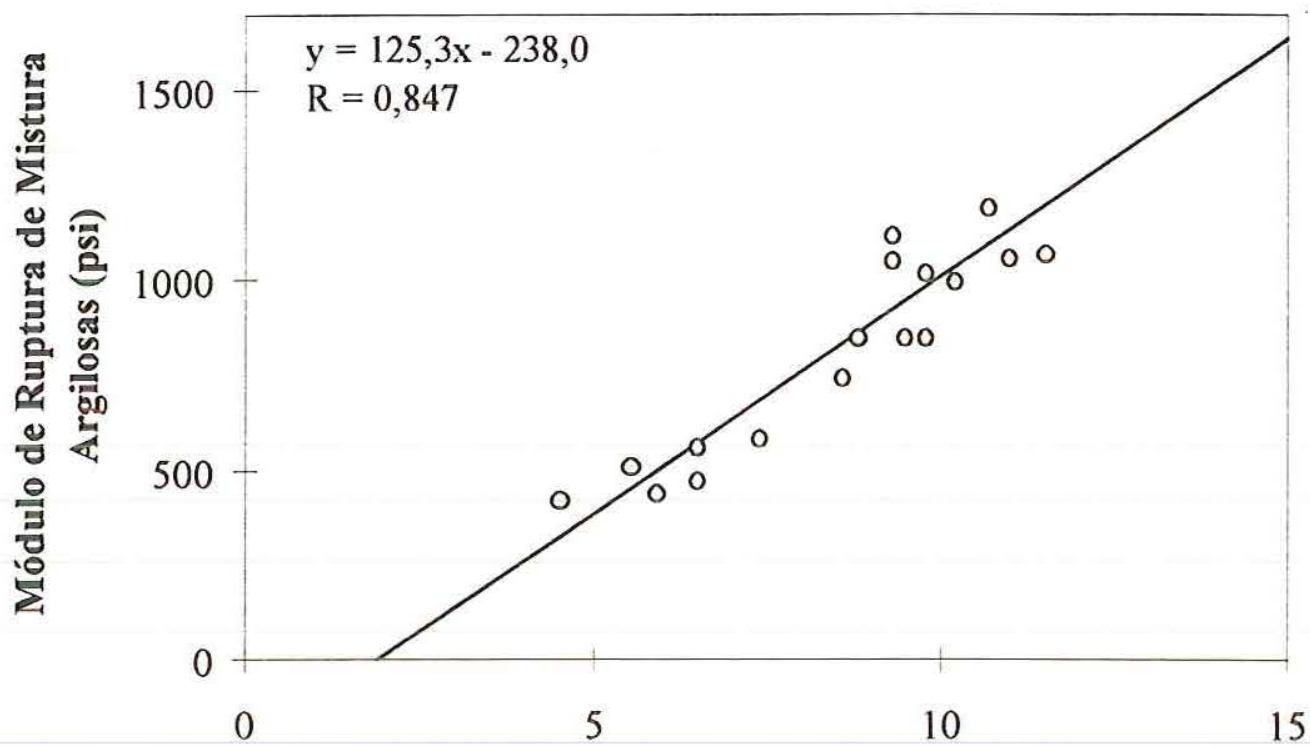

Capacidade de Troca Catiônica (meq/100 g)

Figura 2.4 - Capacidade de troca catiônica versus módulo de ruptura de misturas argilosas, segundo PHELPS \& HARRIS (1970).

HANG \& BRINDLEY (1970) concluíram, por meio de difração de raio X, que a face da molécula de azul de metileno que é adsorvida pelo solo possui uma área entre 130 e $135 \AA^{2}$, sendo um paralelogramo de lados com dimensões aproximadas de 17,0 x 7,6 x 3,25 Å. Ainda segundo os autores, a determinação da superficie específica, SE, (área interna + área externa) é possível quando a superfície dos argilo-minerais fica recoberta por uma camada monomolecular de cátions azul de metileno, permitindo, desta forma, conhecida as dimensões desta molécula, conhecer-se a área total recoberta.

A partir disto, estes autores determinaram a superficie específica (SE) e a capacidade de troca catiônica (CTC) de duas caulinitas, uma ilita e uma montmorilonita utilizando o ensaio de azul de metileno pelo método colorímetro. 
O ensaio de azul de metileno pelo método do colorímetro fundamenta-se no princípio que a intensidade de coloração de uma solução de azul de metileno é proporcional a sua concentração. Desta forma, obtendo-se a curva padrão para o azul de metileno e conhecendo-se a concentração inicial da solução, pode-se, após um intervalo de tempo de contato entre a solução de azul de metileno e uma suspensão aquosa de material argiloso ou de solo, determinar-se, por meio de um colorímetro, a concentração de azul de metileno na solução restante, obtendo-se, por diferença de concentração, a quantidade de azul de metileno adsorvido.

Estes autores discutiram e classificaram o mecanismo de interação do azul de metileno com argilo-minerais em dois tipos: troca catiônica e adsorção.

Na troca catiônica, a molécula do azul de metileno dissocia-se na água e forma cátion de azul de metileno $\left(\mathrm{C}_{16} \mathrm{H}_{18} \mathrm{~N}_{3} \mathrm{~S}^{+}\right)$, que pode permutar com os cátions das argilas. Esta troca é uma reação preferencial que fixa o cátion de azul de metileno na superfície dos argilo-minerais; também, após os cátions das argilas terem sido trocados pelo cátion de azul de metileno, as superficies de argilas transformam-se num estado nãomolhável ou hidrofóbico. A troca catiônica de azul de metileno é considerada uma reação química irreversível. Quando os cátions de azul de metileno na solução foram totalmente trocados, a solução fica límpida e incolor e as argilas assumem a cor azul. Já a adsorção de azul de metileno inclui primeiro o mecanismo de absorção ${ }^{1} \mathrm{e}$, em seguida, o de adsorção ${ }^{2}$; assim, segundo estes autores, a interação da solução aquosa de azul de metileno com argilo-minerais é melhor escrita como uma "ab-adsorção".

CHEN et alii (1974) determinaram a superficie específica (SE) e capacidade de troca catiônica (CTC) de argilas brasileiras com o ensaio de adsorção de azul de metileno pelo método da mancha e fizeram correlações com os resultados das seguintes propriedades tecnológicas: composição química, umidade de prensagem, retração linear, tensão de ruptura, absorção de água, porosidade e perda ao fogo.

\footnotetext{
${ }^{1}$ Absorção: penetração de uma substância nos interstícios do corpo de outra.

${ }^{2}$ Adsorção: incorporação de uma substância à superfície de outra.
} 
Segundo estes autores, o cátion azul de metileno substitui os cátions $\mathrm{Na}^{+}, \mathrm{Ca}^{2+}, \mathrm{K}^{+}$, $\mathrm{Mg}^{2+}$ e $\mathrm{H}_{3} \mathrm{O}^{+}$adsorvidos nos argilo-minerais, ocorrendo um processo de adsorção irreversível, caracterizando-se como uma forma de medida da capacidade de troca de cátions. Concluíram que os resultados permitem prever algumas propriedades tecnológicas utilizadas na indústria cerâmica.

LAN (1977), do LCPC (Laboratoires des Ponts et Chausseés), estudou o ensaio de adsorção de azul de metileno pelo método da mancha para caracterização de solos e correlacionou os resultados com o índice de plasticidade e com o equivalente areia. Com este trabalho, as pesquisas no LCPC evoluíram e em 1979 foi publicado o anteprojeto de padronização do ensaio de adsorção de azul de metileno pelo método da mancha.

Neste anteprojeto no LCPC, foi definido o coeficiente de atividade das frações granulométricas dos solos como sendo a razão entre o "valor de azul" (Vb) do solo multiplicado por 100 e a porcentagem que o solo possui na peneira em análise (por exemplo, para $\%<2 \mu \mathrm{m})$. Dessa forma, o coeficiente de atividade da fração granulométrica menor que $0,002 \mathrm{~mm}$ é calculado segundo a expressão:

$$
\mathrm{CA}_{2}=\frac{\mathrm{Vb} \times 100}{\%<2 \mu \mathrm{m}}
$$

onde:

$\mathrm{CA}_{2}$ : coeficiente de atividade do solo para a fração menor que $0,002 \mathrm{~mm}$; $\mathrm{Vb}$ : valor de azul do solo (g/100 $\mathrm{g}$ de solo); $\%<2 \mu \mathrm{m}$ : porcentagem do solo menor que $0,002 \mathrm{~mm}$.

$\mathrm{O}$ valor de azul ( $\mathrm{Vb})$ foi definido como a quantidade de corante adsorvido por $100 \mathrm{~g}$ de solo. Assim, pode-se avaliar o grau de poluição de areias e de materiais granulares pelas argilas, bem como a argilosidade de solos dentro do domínio da geotecnia, em 
função do consumo de corante ou da superfície específica do material analisado. No Quadro 2.4 estão os valores de superficie específica de argilo-minerais típicos apresentados nesse anteprojeto no LCPC (1979).

Quadro 2.4 - Superfície específica de argilo-minerais obtidas pelo ensaio de adsorção de azul de metileno pelo método da mancha, segundo LCPC (1979).

\begin{tabular}{|c|c|}
\hline Tipo de argila & Superficie Específica $\left(\mathbf{m}^{2} / \mathbf{g}\right)$ \\
\hline montmorilonita & 800 \\
\hline vermiculita & 200 \\
\hline ilita & $40-60$ \\
\hline caulinita & $5-20$ \\
\hline
\end{tabular}

Lan (1980) apresentou dados da variação do consumo de azul de metileno por misturas artificiais de argilas (bentonita + ilita, bentonita + caulinita e ilita + caulinita) com variação de teor de 0 a 100\%. Estes resultados são apresentados na Figura 2.5.

Pode-se observar, através da Figura 2.5, que o consumo de azul de metileno por misturas artificiais de argilas variou linearmente em função da porcentagem de cada tipo de argila. O autor concluiu que a quantidade de azul de metileno adsorvida por uma mistura foi igual à soma ponderada das quantidades de azul de metileno adsorvidas pelos tipos argilosos que estão presentes em sua composição. 


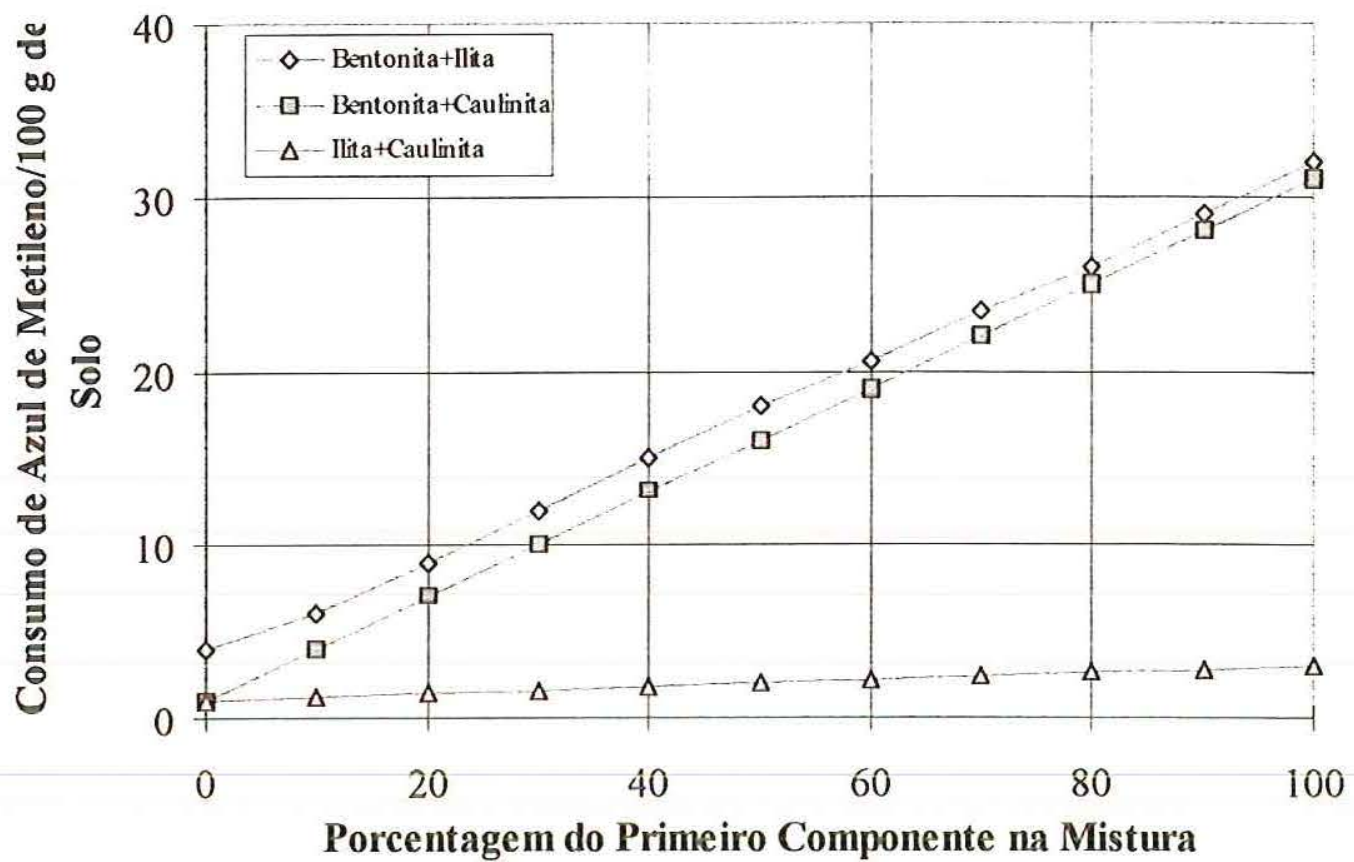

Figura 2.5 - Variação do consumo de azul de metileno em função da quantidade e do tipo de argila nas misturas, segundo LAN (1980).

DENNIS et alii (1980) utilizaram o ensaio de azul de metileno pelo método da mancha para medir a capacidade de absorção de água e expansão de solos e rochas. Segundo estes autores, certas alterações que ocorreram em rochas e solos resultaram no aparecimento de minerais hidrófilos (filosilicatos, argilas, silicatos e óxidos de ferro hidratado) trazendo conseqüências a certas propriedades geotécnicas. O azul de metileno tem a vantagem de não se fixar sobre os minerais inertes (quartzo, calcita) podendo, assim, caracterizar uma certa "atividade" da fase argilosa sem haver a necessidade de se separar essas partículas da rocha ou solo.

O cálculo da superfície específica resulta da adsorção do azul de metileno na face externa e interna da argila, portanto de toda superfície acessivel à água. DENNIS et alii (1980) compararam medidas de superfície específica obtidas pelos método BET e do etileno-glicol com as obtidas pelo de adsorção de azul de metileno pelo método da mancha e os resultados são apresentados no Quadro 2.5. 
Quadro 2.5 - Superficie Específica das argilas, segundo DENNIS et alii (1980)

\begin{tabular}{|c|c|c|c|c|}
\cline { 2 - 4 } \multicolumn{1}{c|}{} & \multicolumn{2}{c|}{ Superfície Específica $\left(\mathrm{m}^{\mathbf{2}} / \mathrm{g}\right)$} & \multicolumn{1}{c}{} \\
\cline { 5 - 5 } Métodos utilizados & Caulinita & Ilita & Montmorilonita & $\begin{array}{c}\text { Tipo de superficie } \\
\text { medida }\end{array}$ \\
\hline BET & 22 & 113 & 82 & externa \\
\hline Etileno-glicol & 45 & 90 & $750-800$ & externa + interna \\
\hline $\begin{array}{c}\text { Adsorção de azul de } \\
\text { metileno pelo } \\
\text { método da mancha }\end{array}$ & 48 & 74 & 860 & externa + interna \\
\hline
\end{tabular}

Foram estudadas ainda, por DENNIS et alii (1980), rochas magmáticas que apresentaram vários estados de alteração. Observando-se os resultados apresentados no Quadro 2.6, nota-se que com o aumento do grau de alteração das rochas há um crescimento do valor de azul de metileno consumido, indicando, possivelmente, a presença de uma quantidade maior de argilo-minerais nestas rochas. Já os resultados apresentados no Quadro 2.7 indicaram que, para o basalto, quanto maior a resistência à compressão da amostra, menor a porcentagem de poros e menor o consumo de azul de metileno, ou seja, o valor de azul de metileno foi relacionado com algumas propriedades das rochas.

LAN (1981) descreveu o ensaio de azul de metileno pelo método da mancha e o coeficiente $\mathrm{Vb}^{3}$ calculado a partir do resultado deste ensaio. Apresentou correlações entre o $\mathrm{Vb}$ e o coeficiente de atividade de Skempton, expondo sua proposta de complementação da classificação de solos RTR (Recommandation pour Terrassements Routiers) com a introdução deste ensaio.

\footnotetext{
${ }^{3}$ Valor de azul do solo (g de azul de metileno/100 $\mathrm{g}$ de solo).
} 
Quadro 2.6 - Adsorção de azul de metileno versus estados de alterações de rochas magmáticas, segundo DENNIS et alii (1980).

\begin{tabular}{|c|c|c|c|c|}
\hline Rochas & \multirow{4}{*}{$\begin{array}{l}\text { Profundidade } \\
\text { de extração } \\
\text { crescente } \uparrow\end{array}$} & Microscópio & Raios X & $\begin{array}{c}\text { Valor de Azul } \\
\text { (g de azul de } \\
\text { metileno } / 100 \mathrm{~g} \\
\text { de material) }\end{array}$ \\
\hline Granito LH 1 & & Ortoclásio & Cloritas + & 0,11 \\
\hline Granito LH 2 & & Quartzo Biotita & Cloritas + & 0,34 \\
\hline Granito LH 3 & & $\begin{array}{c}\text { Alteração crescente } \\
\text { de feldspatos }\end{array}$ & Cloritas ++ & 0,46 \\
\hline Rocha 1 & \multirow{3}{*}{$\begin{array}{c}\text { Alteração } \\
\text { crescente } \downarrow\end{array}$} & $\begin{array}{l}\text { Augita Nefélina } \\
\text { Plagioclásio }\end{array}$ & Montmor + & 0,60 \\
\hline Rocha 2 & & $\begin{array}{l}\text { Augita Nefélina } \\
\text { Plagioclásio }\end{array}$ & $\begin{array}{c}\text { Montmor ++ } \\
\text { Goetita }+\end{array}$ & 2,97 \\
\hline Rocha 3 & & $\begin{array}{c}\text { Plagioclásio: } \\
\text { alteração total de } \\
\text { Augita e } \\
\text { feldspatóides }\end{array}$ & $\begin{array}{c}\text { Montmor } \\
++++ \\
\text { Goetita }++\end{array}$ & 6,60 \\
\hline
\end{tabular}

CASANOVA (1986) analisou trinta e cinco amostras de solos lateríticos brasileiros, abrangendo uma ampla faixa de variação granulométrica, de plasticidade e de composição químico-mineralógica, com o objetivo de caracterização e controle de qualidade aplicados à pavimentação. Foram estudados solos lateríticos com razão sílica-alumina (Ki) entre 0,37 a 1,97 e razão sílica-sesquióxidos $(\mathrm{Kr})$ variando de 0,27 a 1,93. Nesses solos foram determinadas a superficie específica (SE) e a capacidade de troca catiônica (CTC) pelos métodos tradicionais e os resultados foram comparados com os obtidos a partir de ensaios de azul de metileno pelo método da mancha. Os resultados indicaram uma boa correlação entre a CTC obtida pelos métodos tradicionais e a obtida pelo ensaio de adsorção de azul de metileno pelo método da mancha, sendo que, para todos os solos analisados, a CTC pelo ensaio de azul de metileno pelo método da mancha foi sempre menor que a obtida pelo método tradicional. 
Quadro 2.7 - Comparação entre propriedades geotécnicas e valor de azul de certas rochas, segundo DENNIS et alii (1980).

\begin{tabular}{|c|c|c|c|c|c|c|c|}
\hline $\begin{array}{l}\text { Rochas } \\
\text { Naturais }\end{array}$ & Ref. & $\begin{array}{c}\text { Porosidade } \\
(\%)\end{array}$ & $\begin{array}{c}\text { Aumento } \\
\text { de } \\
\text { Volume } \\
10^{-4}\end{array}$ & $\begin{array}{c}\text { Valor } \\
\text { de } \\
\text { Azul (g } \\
\%)\end{array}$ & 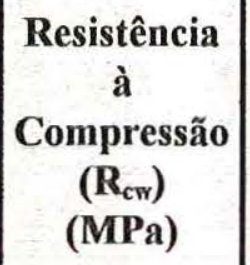 & $\begin{array}{c}(1) \\
\left(\Delta \mathbf{R}_{c}\right) \\
(\%)\end{array}$ & $\begin{array}{c}(2) \\
\Delta \text { Desgaste }\end{array}$ \\
\hline Granito & LH1 & 0,8 & 0,5 & 0,11 & 192 & 19 & 7 \\
\hline Granito & LH4 & 5 & 2,3 & 0,14 & 41 & 37 & 28 \\
\hline Granito & LAl & 1,4 & 1,1 & 0,14 & 153 & 26 & 8 \\
\hline Granito & LA2 & 3,6 & 2,1 & 0,14 & 82 & 27 & 18 \\
\hline Aplito & SC1 & 0,3 & 0,7 & 0,25 & 365 & 19 & 1 \\
\hline Aplito & $\mathrm{SC} 2$ & 0,9 & 1,7 & 0,34 & 249 & 13 & 5 \\
\hline Gabro & NA & 0,2 & 0 & 0,04 & 250 & - & 1 \\
\hline Basalto & RE & 0,4 & 0 & 0,11 & 400 & - & 4 \\
\hline Basalto & RO & 1,2 & 4,8 & 1,25 & 242 & 21 & 26 \\
\hline Rocha A & NO1 & 2 & 1,9 & 0,60 & 170 & 24 & 7 \\
\hline Rocha B & $\mathrm{NO} 2$ & 6,3 & 10 & 2,97 & 132 & 24 & 26 \\
\hline Calcário & MA & 0,5 & 0 & 0,06 & 138 & 0 & 10 \\
\hline Calcário & $\mathrm{BE}$ & 16,5 & 7,6 & 0,97 & 50 & 64 & 70 \\
\hline Calcário & AN & 5 & 0,6 & 0,1 & 166 & 22 & 13 \\
\hline Arenito & $\mathrm{AN}$ & 10,5 & 5 & 0,32 & 71 & 41 & 61 \\
\hline Arenito & LO & 4 & 3 & 0,43 & 182 & 26 & 24 \\
\hline Arenito & CF1 & 0,8 & 0,6 & 0,14 & 247 & 21 & 5 \\
\hline Arenito & CF2 & 5,8 & 8 & 0,18 & 64 & 28 & 50 \\
\hline Arenito & $\mathrm{CH}$ & 0,3 & 0 & 0,07 & 378 & - & 7 \\
\hline Pelito & EAl & 0,4 & 0,5 & 0,64 & 137 & 13 & 11 \\
\hline Pelito & EA2 & 15 & 60 & 2,50 & 20 & 80 & 82 \\
\hline
\end{tabular}

(1) $\mathrm{R}_{\mathrm{cw}}=$ Resistência da rocha saturada.

(2)Aumento de desgaste em presença de água no ensaio Micro Deval.

CASANOVA (1986) citou ainda que não houve uma completa adsorção do azul de metileno pela matéria humificada; que os materiais paracristalinos e amorfos adsorviam pequena quantidade de azul de metileno e que não houve adsorção de azul de metileno pelos óxidos e hidróxidos livres de ferro e alumínio (goetita, gibsita). Tais fatores contribuíram para a aplicação do ensaio de adsorção de azul de metileno pelo método da mancha, pois como a matéria orgânica, os oxi-hidróxidos livres e o material amorfo praticamente não adsorviam azul de metileno, o método media 
essencialmente a capacidade de troca catiônica dos argilo-minerais presentes nas amostras. Este autor concluiu que o ensaio de adsorção de azul de metileno pelo método da mancha deve ser adotado como meio para a caracterização de solos lateríticos, uma vez que propiciou uma maneira rápida, simples e eficaz de determinar as propriedades químicas e físico-químicas de superficie dos solos lateríticos.

LAUTRIN (1987) estudou 99 amostras de solos contendo proporções variadas de argilo-minerais e definiu um método para identificação do tipo de argilo-mineral a partir do ensaio de adsorção de azul de metileno pelo método da mancha.

Foi definido, por LAUTRIN (1987), um índice de nocividade (N), como sendo a razão entre a massa de azul de metileno necessária para recobrir com uma camada monomolecular as partículas contidas em $100 \mathrm{~g}$ de um solo e a porcentagem da fração do solo menor que \# $0,002 \mathrm{~mm}$, conforme mostra a expressão apresentada a seguir:

$$
\mathrm{N}=\frac{100 \times \mathrm{Vb}}{\mathrm{C}_{2}}
$$

onde:

$\mathrm{N}$ : índice de nocividade;

Vb: valor de azul adsorvido (g/100 g de solo);

$\mathrm{C}_{2}$ : porcentagem do solo que passa na \# $0,002 \mathrm{~mm}$.

LAUTRIN (1987) procurou associar o valor da adsorção de azul de metileno (Vb) com a mineralogia das argilas. Desta forma, estabeleceu a influência da mineralogia das argilas sobre a adsorção do azul de metileno.

O Quadro 2.8 apresenta as composições das amostras e a Figura 2.6 apresenta a influência da composição no $\mathrm{Vb}$. Nesta figura verifica-se que houve relação direta entre o aumento da porcentagem de argila e o aumento da adsorção de azul de metileno. Nota-se ainda que, com a variação da proporção de diferentes tipos de argila dentro da fração argilosa, ocorreram mudanças na quantidade adsorvida. 
Quadro 2.8 - Composições das frações argila utilizadas por LAUTRIN (1987).

\begin{tabular}{|c|c|c|c|}
\hline Amostra & Caulinita (\%) & Ilita (\%) & $\begin{array}{c}\text { Montmorilonita } \\
\text { (\%) }\end{array}$ \\
\hline A & 100 & 0 & 0 \\
\hline B & 95 & 5 & 0 \\
\hline C & 95 & 0 & 5 \\
\hline D & 0 & 100 & 0 \\
\hline E & 80 & 0 & 45 \\
\hline F & 10 & 45 & 2 \\
\hline G & 0 & 98 & 85 \\
\hline H & 15 & 0 & 90 \\
\hline I & 10 & 0 & \\
\hline
\end{tabular}

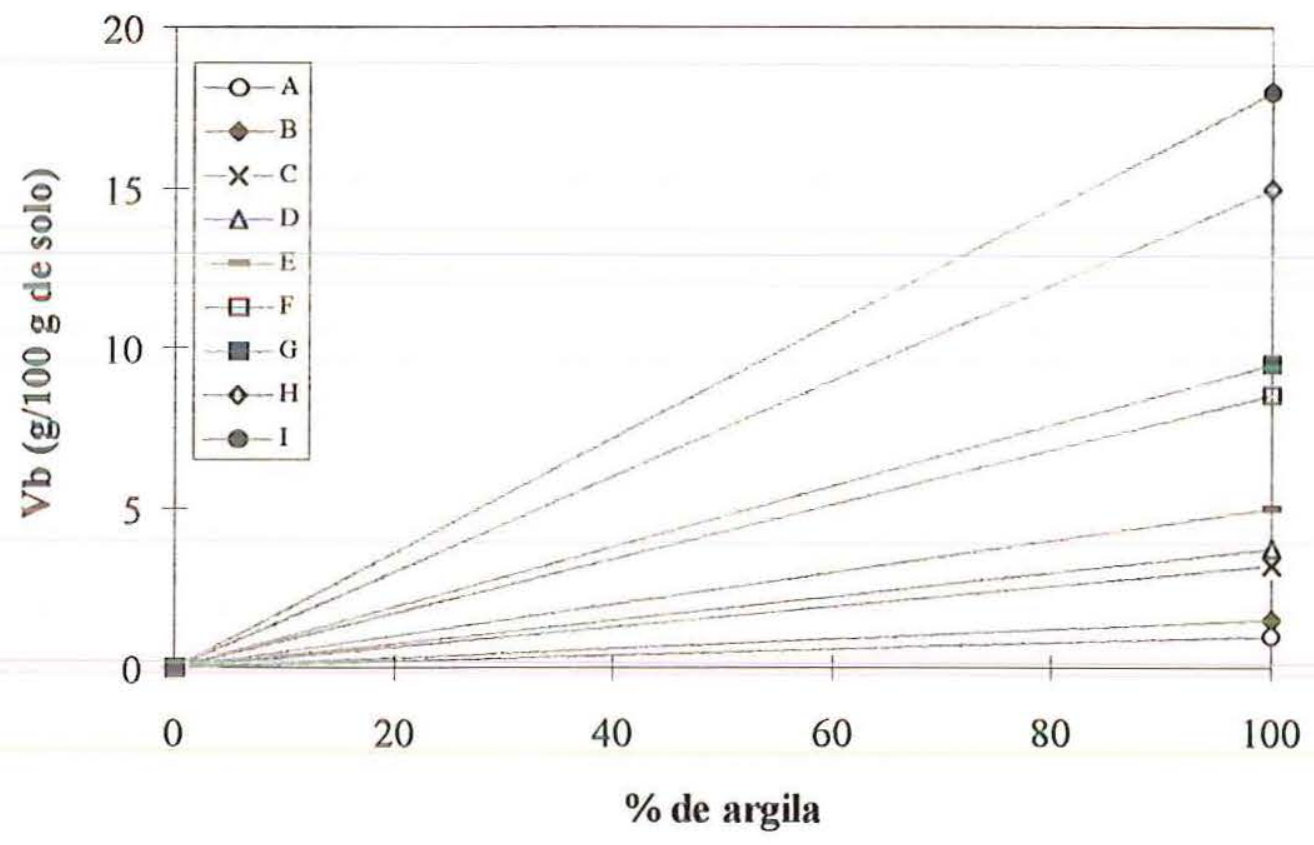

Figura 2.6 - Variação da adsorção de azul de metileno em função da composição das argilas, segundo LAUTRIN (1987). 
Segundo LAUTRIN (1987), para argilo-minerais puros, encontraram-se os seguintes valores do índice de nocividade: 1 a 2 para caulinitas, 4 e 5 para as ilitas e 18 a 20 para as montmorilonitas. Sua conclusão foi que o ensaio de adsorção de azul de metileno pelo método da mancha é um excelente ensaio para a caracterização de solos, fornecendo um meio de qualificar sua fração fina.

HIGGS (1988) utilizou o ensaio de adsorção de azul de metileno pelo método da mancha para verificar a presença de argilo-minerais (esmectitas) em rochas sedimentares e materiais provenientes de brechas. Utilizou amostras moídas e passadas na $\# 0,074 \mathrm{~mm}$, tratadas com uma solução de azul de metileno com concentração de $4,5 \mathrm{~g} / \mathrm{l}$.

SAMESHIMA (1980) et alii, segundo HIGGS (1988), relataram alguns valores básicos de adsorção de azul de metileno, conforme apresentado no Quadro 2.9.

Quadro 2.9 - Valores de adsorção de azul de metileno relatados por SAMESHIMA et alii (1980) segundo HIGGS (1988).

\begin{tabular}{|c|c|c|c|c|c|c|}
\hline $\begin{array}{c}\text { argilo- } \\
\text { minerais }\end{array}$ & $\begin{array}{c}\text { esmectita- } \\
\text { sódica }\end{array}$ & $\begin{array}{c}\text { esmectita- } \\
\text { cálcica }\end{array}$ & ilita pura & $\begin{array}{c}\text { caulinita e } \\
\text { halosita }\end{array}$ & clorita & nontronita \\
\hline $\mathrm{MBA}(\mathrm{ml} / 2 \mathrm{~g})$ & 148,0 & 49,0 & 14,6 & 7,0 & 4,8 & 39,0 \\
\hline
\end{tabular}

Segundo HIGGS (1988), o limite de adsorção de azul de metileno para as argilas do grupo das esmectitas é de $15 \mathrm{ml}$ para $1 \mathrm{~g}$ de amostra. Portanto, se amostra tem uma adsorção maior que 15, conterá, necessariamente, esmectita em sua constituição.

TOURENQ \& LAN (1989) descreveram o princípio do ensaio de azul de metileno pelo método da mancha e sua aplicação na caracterização de rochas, no controle de misturas estabilizadas granulometricamente, na avaliação da argilosiodade de solos e no controle de qualidade de agregados para construção. 
HUET (1989) utilizou o ensaio de azul de metileno pelo método da mancha para a qualificação de "filler" para misturas asfálticas e estabeleceu que, para garantir um produto de boa qualidade, o agregado utilizado deve possuir um equivalente de areia superior a $60 \%$ ou um valor de azul $(\mathrm{Vb})$ inferior a 1 .

FABBRI \& SÓRIA (1991) utilizaram o ensaio de adsorção de azul de metileno pelo método da mancha para fins de classificação de solos, tendo sido ensaiadas quarenta e cinco amostras de solos provenientes de diversos locais do estado de São Paulo, com a finalidade de verificar a variação do consumo de corante em função da classe dos solos obtida da classificação $\mathrm{MCT}^{4}$.

Para a avaliação da "atividade" dos argilo-minerais presentes nos solos, estes autores definiram um coeficiente de atividade (CA), semelhante ao índice de nocividade de LAUTRIN (1987), conforme a expressão apresentada a seguir:

$$
\mathrm{CA}=100 \frac{\mathrm{VT}}{\mathrm{P}_{\mathrm{F}}}
$$

onde:

CA: coeficiente de atividade $\left(10^{-3} \mathrm{~g} / \mathrm{g} \%\right)$;

$\mathrm{P}_{\mathrm{F}}$ : porcentagem, em peso, que o solo contém da fração que se quer avaliar a atividade;

VT: volume total de solução de azul de metileno consumido por $1 \mathrm{~g}$ de amostra de solo integral seco $(\mathrm{ml})$ (com concentração de $1,0 \mathrm{~g}$ de sal anidro por litro de solução).

Como o ensaio foi executado com $1 \mathrm{~g}$ da fração do solo que passa na \#0,074 mm, para o cálculo do volume total (VT) tornou-se necessário levar em consideração a

\footnotetext{
${ }^{4}$ A classificação MCT é um sistema de classificação de solos proposto por NOGAMI \& VILLIBOR (1981), que, entre outras características, permite agrupar os solos em duas classes, conforme seu comportamento quando compactado, a saber: laterítico (L) e não laterítico (N). Esta nova metodologia foi designada de MCT (Miniatura, Compactado, Tropical) devido ao fato de usar corpos de prova de dimensões reduzidas.
} 
porcentagem que o solo teve nesta peneira e o teor de umidade que possui no momento do ensaio. Este cálculo foi realizado segundo a seguinte expressão:

$$
\mathrm{VT}=\mathrm{V} \times \frac{\mathrm{P}_{200}}{100} \times\left(1+\frac{\mathrm{w}}{100}\right)
$$

onde:

VT: volume total de azul de metileno consumido por $1 \mathrm{~g}$ de amostra de solo integral (ml);

$\mathrm{V}$ : volume de azul de metileno adicionado à suspensão durante o ensaio $(\mathrm{ml})$; $\mathrm{P}_{200}$ : porcentagem de solo que passa na $\# 0,074 \mathrm{~mm}$;

w: teor de umidade do solo (\%).

Esses autores verificaram que existe uma boa concordância entre o índice e' da classificação MCT (índice que caracteriza o "caráter" laterítico do solo) e o coeficiente de atividade proposto (CA), tanto para ensaios com variação de $\mathrm{pH}$ como para os diferentes diâmetros que definem a fração ativa.

PEJON (1992) utilizou o ensaio de adsorção de azul de metileno pelo método da mancha para caracterizar solos para fins de mapeamento geotécnico. Foi realizado o ensaio com a fração granulométrica passada na $\# 2,00 \mathrm{~mm}$ e com uma concentração da solução de azul de metileno de $1,5 \mathrm{~g} / \mathrm{l}$, devido à baixa adsorção do corante pelos solos tropicais.

Com os resultados dos ensaios, foram calculados a capacidade de troca catiônica (CTC), a superficie específica (SE), o valor de azul do solo (Vb) e o valor de azul da fração argila (Acb). A CTC obtida do ensaio de azul de metileno pelo método da mancha foi comparada, para cinqüenta e três amostras, com a obtida pelo método utilizado no Instituto Agronômico de Campinas, sendo conseguida uma boa correlação entre os dois resultados, conforme mostrado na Figura 2.7. Obteve-se um coeficiente de correlação igual a 0,90 . 
PEJON (1992) avaliou ainda o comportamento laterítico ou não dos solos utilizando o $\mathrm{Vb}$ (quantidade de azul de metileno, em peso, consumida por $100 \mathrm{~g}$ de solo) juntamente com os resultados da classificação MCT. Concluiu que, para as cento e oito amostras analisadas, o $\mathrm{Vb}$ distinguiu, com uma probabilidade de $85 \%$ de acerto, os solos de comportamento laterítico dos de comportamento não laterítico. Este autor utilizou ainda o valor de azul da fração argila do solo - Acb (quantidade de azul de metileno, em peso, consumida por $100 \mathrm{~g}$ da fração argilosa do solo) para avaliar a atividade do argilo-mineral presente.

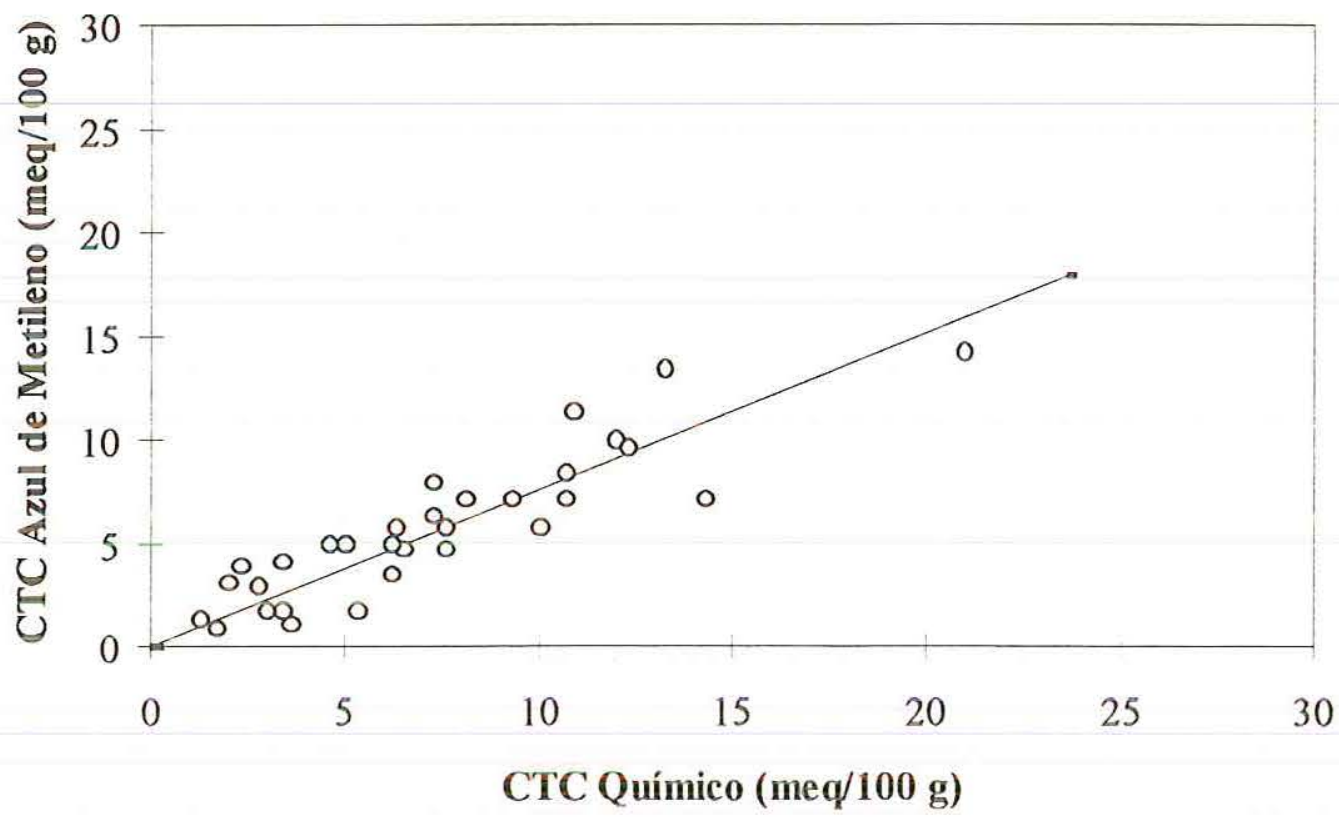

Figura 2.7 - Comparação da capacidade de troca catiônica obtida pelo método do Instituto Agronômico de Campinas e pelo ensaio de adsorção de azul de metileno pelo método da mancha, segundo PEJON (1992).

FABBRI (1994) apresentou uma proposta para caracterização da fração fina de solos tropicais, baseada na superficie específica dos argilo-minerais nela presentes, medida pelo ensaio de adsorção de azul de metileno pelo método da mancha. A partir da superfície específica, determinada pela adsorção do corante azul de metileno, foram 
estabelecidos graus de atividade para os solos analisados. Esta atividade foi então comparada com a previsão de comportamento dos solos, obtida da classificação MCT. Este autor concluiu que a utilização da adsorção de azul de metileno é promissora para a caracterização da fração fina de solos tropicais, permitindo estabelecer, com razoável segurança, a atividade dos argilo-minerais presentes e ainda que existe uma boa concordância entre os resultados da adsorção de azul de metileno e os fornecidos pela classificação MCT para solos tropicais. 


\section{CAPÍTULO 3: AMOSTRAS ESTUDADAS}

\subsection{INTRODUÇÃO}

Foram estudadas nove amostras de rochas basálticas provenientes de afloramentos da Bacia Sedimentar do Paraná. Estas amostras foram coletadas aos pares em cinco pedreiras do interior do estado de São Paulo, ou seja, uma amostra considerada "comercializada" e outra "alterada" para cada pedreira, com exceção da Pedreira de Dois Córregos, onde coletou-se somente uma amostra considerada "alterada", por esta pedreira estar desativada.

As amostras que foram denominadas "alteradas" são aquelas que apresentavam indícios visuais de alteração (cor e textura) e foram coletadas em forma de blocos de rocha, que estavam armazenados em pilha de rejeitos das pedreiras.

As amostras denominadas "comercializadas" são as que apresentavam melhores indicadores de qualidade em relação ao seu par "alterada" para a mesma pedreira e foram coletadas já britadas, diretamente nas saídas das correias transportadoras dos britadores das pedreiras.

Cabe ressaltar que a única amostra coletada da Pedreira de Dois Córregos, denominada como "alterada", apresenta características macroscópicas próprias como a presença de vidro vulcânico ${ }^{1}$ e um menor grau de alteração em relação as amostras denominadas "alteradas" das outras pedreiras.

\footnotetext{
${ }^{1}$ Material não cristalino presente em rochas resultantes do magmatismo extrusivo decorrente de um resfriamento extremamente rápido.
} 


\subsection{LOCALIZAÇÃO E CARACTERÍSTICAS GEOLÓGICAS DAS AMOSTRAS}

Todos os afloramentos em que as amostras foram retiradas pertencem a municípios do interior do Estado de São Paulo (Araraquara, Dois Córregos e São Carlos), conforme apresentado no Quadro 3.1.

Quadro 3.1 - Procedência e localização das amostras coletadas.

\begin{tabular}{|c|c|}
\hline Procedência & Localização \\
\hline Pedreira Bandeirantes & Município de São Carlos (SP), no Jardim Beatriz \\
\hline $\begin{array}{c}\text { Pedreira Dois } \\
\text { Córregos }\end{array}$ & $\begin{array}{c}\text { Rodovia Eng. Paulo Nilo Romano (SP-225), quilômetro } \\
\text { 156, situada no município de Dois Córregos (SP) }\end{array}$ \\
\hline Pedreira Multipedras & $\begin{array}{r}\text { Estrada vicinal ARA-466, a cinco quilômetros da Rodovia } \\
\text { Washington Luís (SP 310), situada no município de }\end{array}$ \\
\hline Pedreira Ouro Fino & $\begin{array}{r}\text { Auraquara (SP) } \\
\text { quilômetros da Rodovia Washington Luís (SP 310), situada } \\
\text { ne município de Araraquara (SP) }\end{array}$ \\
\hline Antonio & $\begin{array}{r}\text { Estrada vicinal Abílio A. Corrêa (ARA-050), a quatro A. Corrêa (ARA-050), a cinco } \\
\text { quilômetros da Rodovia Washington Luís (SP 310), situada } \\
\text { no município de Araraquara (SP) }\end{array}$ \\
\hline
\end{tabular}

As amostras estudadas pertencem a Formação Serra Geral que se encontra no Grupo São Bento, caracterizando-se por rochas vulcânicas toleíticas dispostas em derrames basálticos, com coloração cinza a negra e textura afanítica, segundo o Mapa Geológico do Estado de São Paulo (IPT-1981). 


\subsection{COLETA E PREPARAÇÃO DAS AMOSTRAS}

As amostras foram coletadas manualmente, em uma quantidade aproximada de 200 quilogramas cada, e transportadas até o Laboratório de Estradas do Departamento de Transportes da EESC.

As amostras "alteradas" foram coletadas em forma de blocos de rocha, que estavam armazenados na pilha de rejeitos das pedreiras. Os blocos de rocha foram quebrados, no laboratório, em pedaços menores com o auxílio de uma marreta, resultando numa amostragem média do grau de alteração dos blocos, para que fossem posteriormente submetidos à fragmentação, por meio de um britador de mandíbula Briterpa 1020 com abertura de saída regulada $(3 / 4$ " e $1 / 2 ")$, no Laboratório de Geologia do Departamento de Geotecnia da EESC.

As amostras "comercializadas" foram coletadas já britadas, diretamente nas saídas das correias transportadoras dos britadores de mandíbulas das pedreiras, para brita 0 (diâmetro 9,5-1,2 mm), brita 1 (diâmetro 19,0-4,8 mm), brita 2 (diâmetro 25,0-9,5 $\mathrm{mm}$ ) e brita 3 (diâmetro $50,0-25,0 \mathrm{~mm}$ ), que são destinadas pelas pedreiras à pavimentação.

O Anexo II apresenta as figuras ${ }^{2}$ que ilustram os locais de coleta (pedreiras) das amostras "comercializadas" e "alteradas" utilizadas neste estudo.

Após a etapa de coleta, os materiais foram separados em diferentes faixas granulométricas e quantidades, conforme Quadro 3.2, de acordo com as especificações de cada ensaio a realizar. Esta separação efetuou-se através do peneiramento manual, em seguida os materiais foram embalados em sacos plásticos e numerados para facilitar a identificação durante o estudo experimental.

\footnotetext{
${ }^{2}$ Todas as figuras são fotos originais e coloridas.
} 
Quadro 3.2 - Relação das faixas granulométricas e quantidades de material utilizadas na fase experimental.

\begin{tabular}{|c|c|c|c|}
\hline Ensaios & $\begin{array}{c}\text { Passa na } \\
\text { peneira }(\mathrm{mm})\end{array}$ & $\begin{array}{c}\text { Retido na } \\
\text { peneira }(\mathbf{m m})\end{array}$ & $\begin{array}{l}\text { Amostras } \\
\text { (g) }\end{array}$ \\
\hline Densidade real do agregado miúdo & 4,76 & 2,0 & 500 \\
\hline $\begin{array}{c}\text { Análise granulométrica por } \\
\text { sedimentação }\end{array}$ & 0,074 & - & 60 \\
\hline $\begin{array}{l}\text { Desgaste de agregado por abrasão } \\
\text { "Los Angeles" (Graduação B) }\end{array}$ & $\begin{array}{l}19,1 \\
12,7\end{array}$ & $\begin{array}{l}12,7 \\
9,52\end{array}$ & $\begin{array}{l}2500 \pm 50 \\
2500 \pm 50\end{array}$ \\
\hline $\begin{array}{c}\text { Determinação do índice de } \\
\text { tenacidade de agregados pelo } \\
\text { aparelho Treton }\end{array}$ & 19,1 & 15,9 & $\begin{array}{l}15 \text { a } 20 \\
\text { fragmentos }\end{array}$ \\
\hline Esmagamento & 12,7 & 9,52 & 3000 \\
\hline $\begin{array}{c}\text { Avaliação da resistência mecânica } \\
\text { de agregado pelo método dos } 10 \\
\% \text { de finos }\end{array}$ & 12,7 & 9,52 & 3000 \\
\hline $\begin{array}{l}\text { Adesividade de agregado graúdo a } \\
\text { ligante betuminoso }\end{array}$ & 19,1 & 12,7 & 500 \\
\hline $\begin{array}{l}\text { Adesividade de agregado miúdo a } \\
\text { ligante betuminoso }\end{array}$ & 4,76 & 2,38 & 50 \\
\hline \multirow{2}{*}{$\begin{array}{l}\text { Lixiviação contínua com extrator } \\
\text { "Soxhlet" }\end{array}$} & 19,1 & 12,7 & 4000 \\
\hline & 12,7 & 9,52 & 4000 \\
\hline $\begin{array}{l}\text { Avaliação da durabil. de agreg. } \\
\text { pelo empr. de soluções de sulfato } \\
\text { de sódio ou de magnésio }\end{array}$ & 12,7 & 9,52 & 1000 \\
\hline $\begin{array}{l}\text { Adsorção de azul de metileno pelo } \\
\text { método da mancha }\end{array}$ & 0,074 & - & 100 \\
\hline
\end{tabular}

As amostras foram numeradas, no laboratório, em função de seu local de origem. Para os locais onde foram coletados pares de amostras, identificou-se as amostras "comercializadas" por números ímpares e as "alteradas" por números pares, sendo 
que as amostras provenientes de uma mesma pedreira receberam números consecutivos, como mostra o Quadro 3.3.

Quadro 3.3 - Identificação das amostras ensaiadas.

\begin{tabular}{|c|c|c|c|}
\hline Local & Identificação & Local & Identificação \\
\hline $\begin{array}{c}\text { Pedreira Santo Antonio } \\
\text { Rocha Comercializada }\end{array}$ & 1 & $\begin{array}{r}\text { Pedreira Santo Antonio } \\
\text { Rocha Alterada }\end{array}$ & 2 \\
\hline Pedreira Multipedras & 3 & Pedreira Multipedras & 4 \\
Rocha Comercializada & Rocha Alterada & 6 \\
\hline Pedreira Ouro Fino & 5 & Pedreira Ouro Fino & \\
Rocha Comercializada & 7 & $\begin{array}{r}\text { Pedreira Bandeirantes } \\
\text { Rocha Alterada }\end{array}$ & 8 \\
\hline $\begin{array}{l}\text { Pedreira Bandeirantes } \\
\text { Rocha Comercializada }\end{array}$ & - & $\begin{array}{c}\text { Pedreira Dois Córregos } \\
\text { Rocha Alterada }\end{array}$ & 10 \\
\hline
\end{tabular}




\section{CAPÍTULO 4: PROGRAMA DE ENSAIOS}

\subsection{INTRODUÇÃO}

A utilização de agregados rochosos em engenharia civil exige certas características mínimas de qualidade, notadamente para uso em pavimentação. Para isso devem ser conhecidas algumas propriedades que influem no comportamento da rocha, tais como: composição mineralógica, textura, estrutura, índices físicos, presença de substâncias deletérias (argilo-minerais), resistência ao desgaste, resistência ao impacto (tenacidade), resistência ao esmagamento e alterabilidade. Para tal fim, existem inúmeros ensaios de laboratório que procuram estabelecer a qualidade dos agregados em função da sua utilização.

Neste capítulo são descritos os ensaios realizados durante a pesquisa e que foram divididos em seis grupos:

a) Determinações analíticas: Difratometria de raios $\mathrm{X}$, Análise petrográfica macroscópica e Análise petrográfica microscópica;

b) Determinações complementares: Densidade real de agregado miúdo (método do picnômetro) e Análise granulométrica por Sedimentação (método do densímetro);

c) Ensaios físico-mecânicos: Desgaste de agregado por abrasão "Los Angeles", Determinação do índice de tenacidade de agregados pelo aparelho Treton, Esmagamento e Avaliação da resistência mecânica de agregados pelo método dos $10 \%$ de finos;

d) Ensaios de adesividade: Adesividade de agregado graúdo a ligante betuminoso e Adesividade de agregado miúdo a ligante betuminoso; 
e) Ensaios de alteração: Lixiviação contínua com extrator "Soxhlet" e Avaliação da durabilidade de agregados pelo emprego de soluções de sulfato de sódio $\left(\mathrm{Na}_{2} \mathrm{SO}_{4}\right)$ ou de magnésio $\left(\mathrm{MgSO}_{4}\right)$;

f) Ensaio de adsorção de azul de metileno pelo método da mancha.

Descrevem-se, a seguir, todas as etapas e os procedimentos realizados no laboratório para a caracterização das amostras "comercializadas" e "alteradas" coletadas nas pedreiras.

\subsection{DETERMINAÇÕES ANALÍTICAS}

\subsubsection{DIFRATOMETRIA DE RAIOS X}

Os ensaios de difratometria de Raios $\mathrm{X}$ têm a finalidade de identificar os minerais cristalinos presentes na rocha. $\mathrm{O}$ fato dos cristais funcionarem como redes de difração para os raios $\mathrm{X}$ faz com que possam ser identificados pela mencionada radiação.

As amostras submetidas a este ensaio, obtidas através de peneiramento de finos produzidos no ensaio de Desgaste de agregado por abrasão "Los Angeles", foram passadas na peneira $\# 0,074 \mathrm{~mm}$ e submetidas à difratometria de raios $\mathrm{X}$ pelo Método do Pó, no Laboratório de Cristalografia do Departamento de Química e Física Molecular do Instituto de Química de São Carlos da USP. Utilizou-se tubo de raios X de cobre, corrente de $20 \mathrm{~mA}$, diferença de potencial de $40 \mathrm{kV}$.

No Anexo II apresenta-se a interpretação dos difratogramas de raios X, para detectar a presença de minerais, que foi realizada com o auxílio de informações contidas em BRINDLEY \& BROWN (1980). 


\subsubsection{ANÁLISE PETROGRÁFICA MACROSCÓPICA}

As análises petrográficas macroscópicas foram realizadas seguindo-se o roteiro adotado no IPT, segundo FRAZÃO \& AUGUSTO (1994), conforme apresentado no Quadro 4.1.

Neste quadro foram reunidas as principais características macroscópicas das rochas e suas relações com o seu estado de alteração e coerência. Estes critérios podem ser adotados em caráter preliminar para caracterização rotineira de rochas para uso na construção civil.

SCHNEIDER \& PIRES (1968) citaram como indicadores de boa qualidade as seguintes características macroscópicas dos basaltos: cor preta, fratura uniforme, arestas e cantos vivos, ausência de vazios e de fissuras. Ao contrário, as características indicadoras de má qualidade seriam: cores claras (cinza-claro, cinzaesverdeado, etc), abundância de vazios, fraturas irregulares, arestas e cantos arredondados e alta produção de pó na britagem.

A estas características pode-se acrescentar o teste de impacto com martelo que, para basaltos sãos, haverá emissão de sons agudos, enquanto que para basaltos alterados resultará sons abafados (sons graves).

Pode-se, também, submeter a amostra a umedecimento com água, que, para basaltos alterados, resultará em escurecimento, com demora na recuperação da cor original.

As características macroscópicas não são, entretanto, suficientes para avaliar a qualidade da rocha, havendo necessidade de efetuar-se a uma análise petrográfica microscópica, que fornecerá informações para uma melhor interpretação dos ensaios realizados. 
Quadro 4.1 - Roteiro para avaliação preliminar do estado de alteração e do grau de coerência de rochas, segundo FRAZÃO \& AUGUSTO (1994).

\begin{tabular}{|c|c|c|c|}
\hline Parâmetro & Rocha & Sigla & Característica \\
\hline \multirow{4}{*}{ ALTERAÇÃO } & Sã & Al & $\begin{array}{l}\text { - Macroscopicamente não há indícios } \\
\text { de alterações fisicas e/ou químicas } \\
\text { dos minerais. } \\
\text { - Minerais apresentam brilho. }\end{array}$ \\
\hline & $\begin{array}{l}\text { Pouco } \\
\text { Alterada }\end{array}$ & A2 & $\begin{array}{l}\text { - Alteração incipiente dos minerais. } \\
\text { - Em geral a rocha exibe pouca } \\
\text { descoloração. }\end{array}$ \\
\hline & $\begin{array}{l}\text { Medianamente } \\
\text { Alterada }\end{array}$ & A3 & $\begin{array}{l}\text { - Minerais medianamente alterados, } \\
\text { geralmente não apresentam brilho. } \\
\text { - Rocha bastante descolorida. }\end{array}$ \\
\hline & $\begin{array}{l}\text { Muito } \\
\text { Alterada }\end{array}$ & A4 & $\begin{array}{l}\text { - Minerais muito alterados, por vezes } \\
\text { pulverulentos e friáveis, totalmente } \\
\text { sem brilho. }\end{array}$ \\
\hline \multirow{4}{*}{ COERÊNCIA } & Coerente & $\mathrm{C} 1$ & $\begin{array}{l}\text { - Quebra com dificuldade ao golpe do } \\
\text { martelo produzindo poucos } \\
\text { fragmentos e com bordas cortantes. } \\
\text { - Superficie dificilmente riscável por } \\
\text { lâmina de aço. }\end{array}$ \\
\hline & $\begin{array}{l}\text { Medianamente } \\
\text { Coerente }\end{array}$ & $\mathrm{C} 2$ & $\begin{array}{l}\text { - Quebra com relativa facilidade ao } \\
\text { golpe do martelo produzindo } \\
\text { fragmentos com bordas quebradiças } \\
\text { por pressão dos dedos. Superficie } \\
\text { riscável com lâmina de aço, deixando } \\
\text { sulcos leves. }\end{array}$ \\
\hline & $\begin{array}{c}\text { Pouco } \\
\text { Coerente }\end{array}$ & $\mathrm{C} 3$ & $\begin{array}{l}\text { - Quebra com muita facilidade ao } \\
\text { golpe do martelo (esfarela) } \\
\text { produzindo fragmentos que podem } \\
\text { ser partidos manualmente. Superfície } \\
\text { riscável com lâmina de aço, deixando } \\
\text { sulcos profundos. } \\
\end{array}$ \\
\hline & Incoerente & $\mathrm{C} 4$ & $\begin{array}{l}\text { - Quebra facilmente com pressão dos } \\
\text { dedos, desagregando-se. Pode ser } \\
\text { cortada com lâmina de aço. }\end{array}$ \\
\hline
\end{tabular}




\subsubsection{ANÁLISE PETROGRÁFICA MICROSCÓPICA}

A análise petrográfica microscópica foi executada através de exame de lâminas delgadas em microscópio óptico. Através destas análises microscópicas pode-se qualificar os minerais sãos e alterados existentes em uma rocha a partir da análise da interferência sofrida pela luz polarizada ao atravessar lâminas delgadas de rocha. Para isto, as lâminas foram preparadas, através de corte e desgaste com materiais abrasivos e posteriormente analisadas no Laboratório de Geologia do Departamento de Geotecnia da EESC.

\subsection{DETERMINAÇÕES COMPLEMENTARES}

\subsubsection{DENSIDADE REAL DE AGREGADO MIÚDO - MÉTODO DO PICNÔMETRO}

Os ensaios de densidade real de agregado miúdo pelo método do picnômetro foram realizados conforme o método ME 84-64 do Departamento Nacional de Estradas de Rodagem.

\subsubsection{ANÁliSE GRANULOMÉTRICA POR SEDIMENTAÇÃO MÉTODO DO DENSÍMETRO}

Foram realizados um ensaio de análise granulométrica por sedimentação pelo método do densímetro para cada amostra, segundo o método ME 51-64 do Departamento Nacional de Estradas de Rodagem. Os resultados são apresentados no Anexo III. 


\subsection{ENSAIOS FÍSICO-MECÂNICOS}

\subsubsection{DESGASTE DE AGREgAdO POR ABRASÃO "LOS ANGELES"}

É um ensaio onde a rocha é submetida tanto ao desgaste superficial, através do atrito entre os agregados e as cargas abrasivas e os agregados entre si, como também a impactos, devido à ação da queda que os agregados sofrem, em cada volta, com a parede interna da máquina de abrasão "Los Angeles".

Foram executados três ensaios de desgaste de agregado por abrasão "Los Angeles" para cada amostra, segundo o método ME 35-64 do Departamento Nacional de Estradas de Rodagem, na graduação B e determinou-se a média aritmética.

\subsubsection{DETERMINAÇÃO DO ÍNDICE DE TENACIDADE DE AGREGADOS PELO APARELHO TRETON}

O ensaio de determinação do índice de tenacidade de agregados pelo aparelho Treton, adaptado pelo Instituto de Pesquisas Tecnológicas do Estado de São Paulo (IPT $\mathrm{ME}$ - 52), foi desenvolvido para medir quantitativamente o comportamento de uma amostra de rocha ao impacto. O valor obtido é importante nos casos onde a rocha é submetida a impactos repetidos, seja como material solto, seja com ligante. Sua principal aplicação é na escolha de materiais rochosos para pavimentos, pistas de aeroportos e lastros para vias férreas.

Segundo YOSHIDA (1972), a resistência ao impacto é influenciada pelas características petrográficas, tais como: composição mineralógica e textura. Em 
rochas ígneas, os grãos cristalinos geralmente estão fortemente interligados constituindo uma textura densa e ocasionando elevadas resistências ao impacto.

\subsubsection{ENSAIO DE ESMAGAMENTO}

É um ensaio que procura mostrar o comportamento da rocha (agregado) quanto à sua fragmentação, quando submetida a esforços de compressão. Este tipo de solicitação é bastante comum em lastro ferroviário e pavimentação rodoviária, onde o fenômeno ocorre desde a fase de construção e continua por toda a vida útil. Assim como as demais propriedades mecânicas, a resistência ao esmagamento da rocha está intimamente ligada às suas características petrográficas.

Os ensaios de esmagamento foram realizados, um para cada amostra, segundo o método do Instituto de Pesquisas Tecnológicas do Estado de São Paulo (IPT - ME 53). Neste ensaio, foram utilizadas $3000 \mathrm{~g}$ de amostra que passam na peneira de $\# 12,7 \mathrm{~mm}$ e ficam retidas na de $\# 9,52 \mathrm{~mm}$.

Com este material encheu-se um recipiente cilindrico, de dimensões padronizadas, com três camadas sucessivas de mesma altura, aplicando-se, em cada camada, 25 golpes com o auxílio de uma haste de socamento. O excesso de material foi removido rasando-se a amostra no recipiente cilíndrico com a própria haste de socamento. Determinou-se a massa do agregado contido no recipiente cilíndrico $\left(\mathrm{P}_{\mathrm{a}}\right)$.

Colocou-se esta quantidade de amostra $\left(\mathrm{P}_{\mathrm{a}}\right)$ no cilindro da prensa e inseriu-se o êmbolo para compressão no cilindro. Este conjunto foi, em seguida, colocado no prato da prensa e cuidadosamente centrado. Aplicou-se então a carga de compressão estática de 40 toneladas. A velocidade de carregamento foi de 4 ton/min. Aplicada a carga total, o conjunto foi retirado da prensa, removendo-se todo o material contido no cilindro de ensaio. Após o ensaio, o material é passado na peneira de \#2,38 $\mathrm{mm}$. 
A perda do agregado ao esmagamento é calculada pela relação porcentual entre a diferença entre as massas inicial e final e a massa inicial.

$$
P=100 \times \frac{P_{i}-P_{f}}{P_{i}}
$$

onde:

P: perda do agregado ao esmagamento (\%);

$\mathrm{P}_{\mathrm{i}}$ : massa total da amostra seca, antes do ensaio $(\mathrm{g})$;

$\mathrm{P}_{\mathrm{f}}$. massa do material retido na peneira de \#2,38 mm, após o ensaio (g).

\subsubsection{AVALIAÇÃO DA RESISTÊNCIA MECÂNICA DE AGREGADOS PELO MÉTODO DOS $10 \%$ DE FINOS}

Este ensaio consiste na determinação da carga necessária para que se produzam, em uma amostra de agregado graúdo submetido a esmagamento, $10 \%$ de finos, mantendo-se análogas a amostragem e aparelhagem utilizadas para o ensaio de esmagamento citado anteriormente.

Os ensaios foram executados segundo o método ME 096-94 do Departamento Nacional de Estradas de Rodagem. Realizou-se um ensaio para cada amostra.

\subsection{ADESIVIDADE DE AGREGADO A LIGANTE BETUMINOSO}

Na pavimentação, o material betuminoso age como um aglutinante para os agregados, que recebem e transmitem às camadas inferiores os esforços oriundos do tráfego. $\mathrm{O}$ material betuminoso deve envolver completamente o agregado, formando uma massa coesa que resista às solicitações provenientes do tráfego, às intempéries e dê 
flexibilidade ao pavimento. Para que não ocorra desagregação prematura do pavimento, deve sempre haver uma perfeita adesividade entre o agregado e o ligante betuminoso. A adesividade de agregado a ligante betuminoso depende dos tipos, das características das rochas e dos materiais betuminosos empregados.

Segundo PICCOLO \& ADISSY (1970), algumas características dos agregados podem influir na adesividade, a saber:

a) Textura: A área de contato agregado-ligante betuminoso depende do tamanho e da disposição dos minerais que constituem as rochas. Quanto mais irregular for a superficie do agregado maior será a área de contato, favorecendo a adesividade;

b) Porosidade: A absorção física em relação ao ligante betuminoso, devida a forças capilares ocasionadas pela presença de poros, beneficia a adesividade;

c) Minerais: A adsorção química, devida à estrutura cristalina e à composição química dos minerais, influi na adesividade;

d) Limpeza: os agregados devem estar isentos de substâncias nocivas tais como matéria orgânica, argila, pó de pedra etc. A presença de finos ou água, na superfície ou nos poros, dificulta a aderência entre os materiais, prejudicando a adesividade.

Os ensaios de adesividade a ligante betuminoso utilizados no Brasil são os do "Road Research Laboratory" modificado e o de "Riedel-Weber", adaptados pelo DNER e DER-SP, respectivamente. Estes métodos de ensaio, segundo DEGANI et alii (1979), foram baseados nas normas norte-americanas, onde os estudos de desenvolvimento de rodovias envolvem a fixação de parâmetros empíricos, válidos para as condições climáticas representativas daquele país. O clima temperado, predominante na maior parte da América do Norte, apresenta características climáticas rígidas como temperaturas baixas e congelamento. No Brasil, de clima tropical, as circunstâncias são severas, mas inversas, ou seja, temperaturas altas. Sendo assim, há uma 
discrepância entre as condições em que foram desenvolvidos os métodos de ensaio e as existentes onde são aplicados.

Os métodos de ensaio de adesividade utilizados nesta pesquisa são descritos a seguir.

\subsubsection{ADESIVIDADE DE AGREGADO GRAÚDO A LIGANTE BETUMINOSO}

Realizou-se um ensaio de adesividade de agregado graúdo a ligante betuminoso para cada amostra, segundo o método ME 78 -63 do Departamento Nacional de Estradas de Rodagem.

\subsubsection{ADESIDADE DE AGREGADO MIÚDO A LIGANTE BETUMINOSO}

Foram realizados um ensaio de adesividade de agregado miúdo para cada amostra segundo o método M 149-61 do Departamento de Estradas de Rodagem do Estado de São Paulo.

Este ensaio consiste da avaliação do deslocamento da película de asfalto quando a mistura agregado-ligante é submetida à ação de água destilada em ebulição e à ação da soluções de carbonato de sódio $\left(\mathrm{Na}_{2} \mathrm{CO}_{3}\right)$ com diferentes concentrações, também em ebulição. 


\subsection{ENSAIOS DE ALTERAÇÃO}

O objetivo dos ensaios de alteração é simular em laboratório a ação de agentes de alterações naturais através de solicitações físicas e físico-químicas. De um modo geral, estes ensaios procuram exagerar as condições ambientais e, através de agentes simuladores, solicitar eficientemente as propriedades que possam prever as alterações da rocha em estudo.

\subsubsection{ENSAIO DE ALTERAÇÃO POR LIXIVIAÇÃO CONTÍNUA COM EXTRATOR "SOXHLET" CONJUGADO COM DESGASTE DE AGREGADO POR ABRASÃO "LOS ANGELES"}

A alteração experimental de rochas em laboratório, manipulando extratores tipo "Soxhlet", foi descrita no trabalho de GEORGES PÉDRO (1964) segundo FARJALLAT (1971). Este autor preocupou-se com os aspectos mineralógicos e geoquímicos, isto é, com o comportamento dinâmico dos elementos químicos e neoformações de minerais. MELFI, segundo FARJALLAT (1972), introduziu o uso desta técnica para estudo geoquímico da evolução de rochas.

FARJALLAT (1971) implantou este ensaio no laboratório de alteração experimental de rochas montado no IPT, em São Paulo, estudando a mineralogia, geoquímica e os aspectos mecânicos do processo de alteração experimental, de maior interesse para a Engenharia Civil.

Segundo FRAZÃO \& AUGUSTO (1994), este ensaio solicita as rochas por remoção iônica (a diminuição de elementos alcalinos e alcalino-terrosos indica que a rocha encontra-se em processo de alteração), além de promover a hidratação de minerais secundários através da saturação em água aquecida. A alteração acelerada no extrator 
"Soxhlet" provoca uma lixiviação contínua, pelo fato da água percolar pela amostra a uma temperatura de 60 a $70^{\circ} \mathrm{C}$, possibilitando o arrastamento em solução de certos produtos de alteração. $\mathrm{O}$ ambiente climático no interior do extrator assemelha-se a um clima tropical úmido de alta temperatura e alta pluviosidade, simulando condições climáticas de vastas regiões brasileiras.

Para avaliação da alterabilidade dos agregados, utilizou-se o processo de lixiviação contínua com extrator "Soxhlet".

O extrator utilizado foi de grandes dimensões (8 $\mathrm{kg}$ de amostra), conforme apresentado na Figura 4.1. Foram realizados dez e quarenta ciclos de lixiviação para cada amostra, sendo que cada ciclo de enchimento - esvaziamento demorou aproximadamente cinco horas.

O extrator "Soxhlet", conforme ilustra a Figura 4.2, consiste essencialmente de um balão, um tubo extrator, uma unidade de condensação e um sifão. A água evaporada no balão é condensada graças a uma unidade de aquecimento controlável e se precipita sobre a amostra, infiltrando-se nos fragmentos. Quando a água atinge o nível do sifão, é sifonada de volta para o balão, iniciando um novo ciclo.

Neste equipamento, pode-se distinguir três regiões:

a) Zona Atmosférica: velocidade de percolação da água muito grande;

b) Zona de Flutuação do Nível Freático: amostras alternadamente imersas e emersas;

c) Zona de Saturação Permanente: amostras permanentemente imersas.

O extrator "Soxhlet" tenta simular no laboratório as condições naturais de alteração, mas em velocidade muito maior, graças a temperatura mais alta e velocidade de percolação de água também muito maior que a encontrada na natureza. 
Após o término do ensaio de lixiviação, optou-se por executar o ensaio de desgaste de agregado por abrasão "Los Angeles", como parâmetro auxiliar para quantificar a eventual queda de resistência mecânica originada pelo ensaio de alteração.

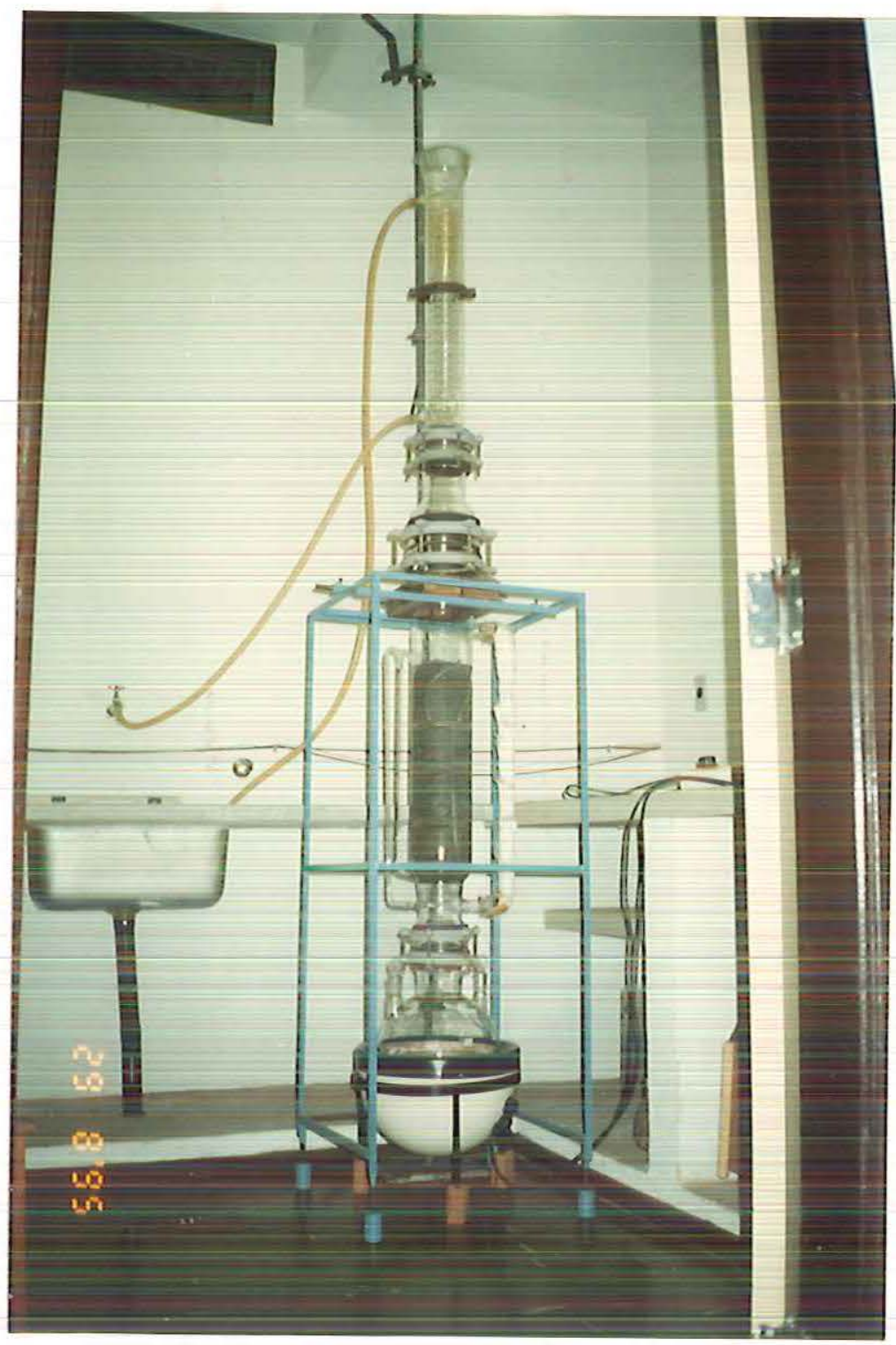

Figura 4.1 - Equipamento utilizado no ensaio de alteração por lixiviação contínua com o extrator "Soxhlet". 


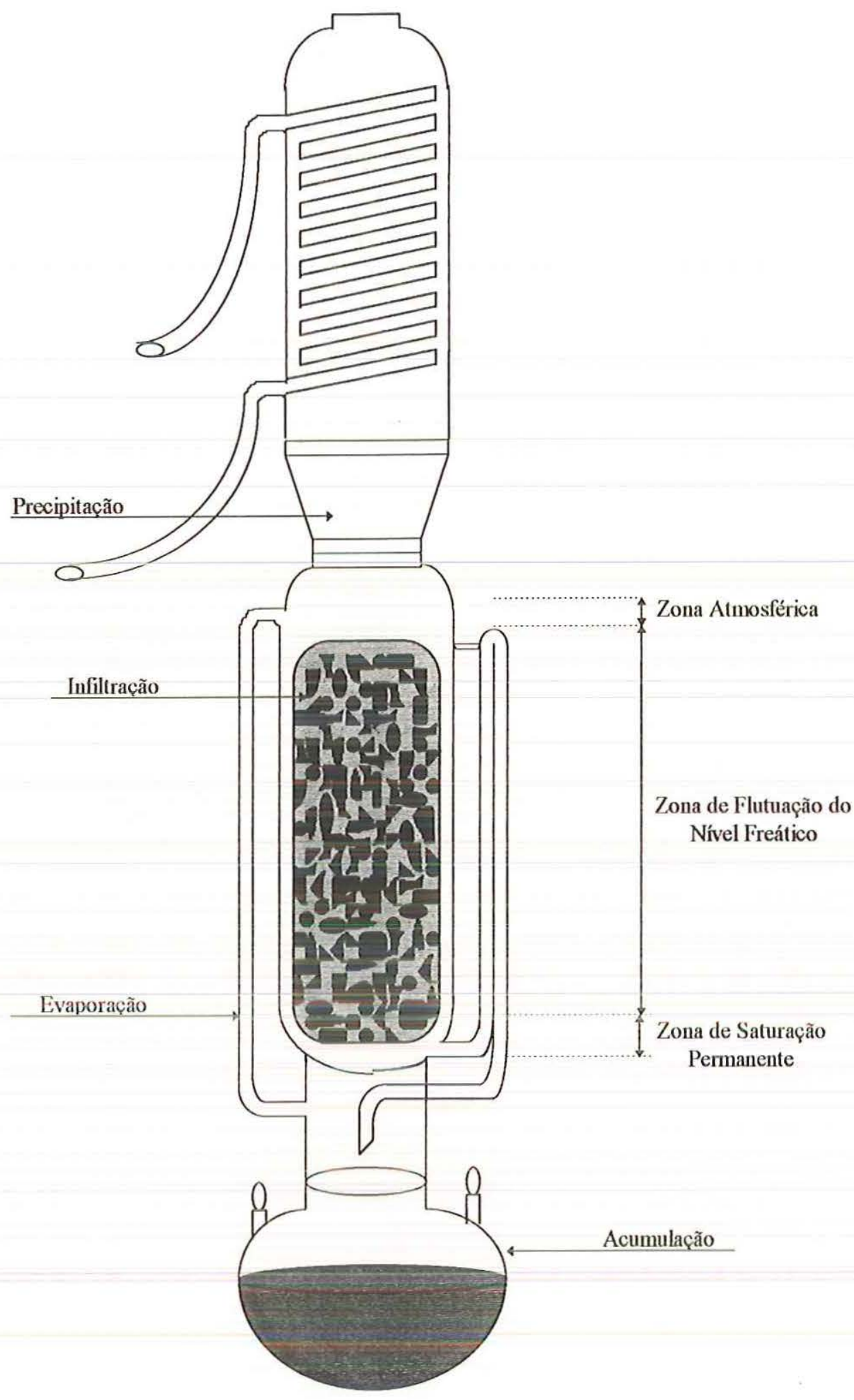

Figura 4.2 - Esquema do equipamento para o ensaio de alteração por lixiviação contínua com extrator "Soxhlet" (Figura sem dimensões). 
O ensaio de desgaste de agregado por abrasão "Los Angeles" foi selecionado dentre os outros ensaios mecânicos pelos seguintes fatores:

- ensaio relativamente simples de executar e amplamente conhecido;

- o valor de desgaste a abrasão "Los Angeles" é muito utilizado em especificações para pré-avaliação da qualidade de agregados rochosos para pavimento e concreto;

- facilidade na preparação das amostras para o ensaio;

- a resistência a abrasão "Los Angeles" depende da tenacidade e do desgaste por abrasão das rochas, propriedades ligadas à alteração.

As amostras utilizadas no ensaio para avaliação da alterabilidade de rochas e posteriormente no ensaio de desgaste de agregado por abrasão "Los Angeles", tiveram o seguinte procedimento:

Preparou-se dezesseis quilogramas de cada amostra, sendo divididas em oito quilogramas para o ensaio de lixiviação contínua de 10 ciclos e oito quilogramas para o de quarenta ciclos.

Estas amostras foram preparadas na graduação B, escolhida para a execução do ensaio de desgaste de agregado por abrasão "Los Angeles". Após os dez e quarenta ciclos, as amostras foram secas em estufa a $100^{\circ} \mathrm{C}$, esfriadas à temperatura ambiente $\mathrm{e}$ peneiradas para a realização do ensaio de desgaste de agregado por abrasão "Los Angeles".

Após o término dos números de ciclos programados (10 e 40) de lixiviação contínua para cada amostra, foram coletadas, no balão, as soluções aquosas destes ensaios, para obter-se informações sobre o estado de alteração da rocha, pois o processo intempérico provoca a remoção de íons (lixiviação), modificando a composição química original da água, como citado anteriormente. 
A dosagem de cada elemento, para todas as amostras, foi determinada por espectrofotometria de absorção atômica, no Laboratório de Saneamento do Departamento de Hidraúlica e Saneamento da EESC. As influências das contaminações devidas aos recipientes utilizados foram determinadas pelo uso sistemático de "brancos". As análises químicas foram realizadas para os seguintes constituintes: $\mathrm{Ca}^{+2}, \mathrm{Mg}^{+2}, \mathrm{~K}^{+} \mathrm{e} \mathrm{Na}^{+}$.

Para estes elementos, PARKER (1970) definiu o índice de proporções de metais alcalinos e alcalino-terrosos (I) presentes na amostra:

$$
I=\left(\frac{(\mathrm{Na})_{a}}{(\mathrm{Na}-\mathrm{O})_{b}}+\frac{(\mathrm{Mg})_{\mathrm{a}}}{(\mathrm{Mg}-\mathrm{O})_{\mathrm{b}}}+\frac{(\mathrm{K})_{\mathrm{a}}}{(\mathrm{K}-\mathrm{O})_{\mathrm{b}}}+\frac{(\mathrm{Ca})_{\mathrm{a}}}{(\mathrm{Ca}-\mathrm{O})_{\mathrm{b}}}\right) \times 100
$$

onde:

$(\mathrm{X})_{\mathrm{a}}$ : proporção atômica do elemento " $\mathrm{X}$ ", definida como a porcentagem atômica dividida pelo peso atômico;

(X-O): força da ligą̧ão do elemento " $\mathrm{X}$ " com o oxigênio. Usando os valores de NICHOLL'S (1963), segundo PARKER (1970), obteve-se:

$$
I=\left(\frac{(\mathrm{Na})_{\mathrm{s}}}{0,35}+\frac{(\mathrm{Mg})_{\mathrm{s}}}{0,90}+\frac{(\mathrm{K})_{\mathrm{a}}}{0,25}+\frac{(\mathrm{Ca})_{\mathrm{a}}}{0,70}\right) \times 100
$$

Segundo PARKER (1970), através deste índice pode-se medir o grau de alteração alcançado em relação à rocha original. Este índice é aplicável a rochas ígneas e é válido em todas as situações onde a hidrólise é a principal reação no processo de decomposição. Os valores deste índice diminuem com o aumento do grau de alteração, quando não ocorre um enriquecimento temporário dos elementos. 


\subsubsection{AVALIAÇÃO DA DURABILIDADE DE AGREGADOS PELO EMPREGO DE SOLUÇÕES DE SULFATO DE SÓDIO OU DE MAGNÉSIO}

As alterações devidas à cristalização de sais são freqüentes em ambientes desérticos, mediterrâneos e tropicais. A resistência de rochas à desagregação por cristalização de sais, segundo YOSHIDA (1972), é mais relacionada à sua estrutura petrográfica que à sua composição química e é função de sua densidade.

Conforme YOSHIDA (1972), o que ocorre com a rocha é uma ação superficial marcante, seja por uma regularização das rugosidades superficiais, seja por descalçamento de minerais no caso de rochas granulares.

Isto é possível pois as tensões geradas por certos sais quando se cristalizam ou se hidratam nos vazios de uma rocha, devido ao estado de confinamento, tendem a fragmentar as partículas do agregado, degradando sua granulometria. Este ensaio tem como objetivo indicar as condições de intemperismo pela cristalização dos sais nos poros e microfissuras dos agregados, simulando a alterabilidade dos materiais quando sujeitos a agentes climáticos (em especial baixas temperaturas).

Foi realizado um ensaio por amostra, utilizando-se o método ME 89-64, do Departamento Nacional de Estradas de Rodagem, com sulfato de sódio $\left(\mathrm{Na}_{2} \mathrm{SO}_{4}\right)$ e cinco ciclos de alteração.

Pode-se determinar a resistência à desagregação dos agregados sujeitos à ação do tempo pelo ataque de soluções saturadas de sulfato de sódio $\left(\mathrm{Na}_{2} \mathrm{SO}_{4}\right)$ ou de sulfato de magnésio $\left(\mathrm{MgSO}_{4}\right)$.

As soluções de sulfato de sódio foram preparadas dissolvendo-se aproximadamente 10 quilogramas de sal em 15 litros de água destilada, a uma temperatura entre $25^{\circ} \mathrm{e}$ $30^{\circ} \mathrm{C}$, assegurando a saturação e a presença de excesso de cristais nas soluções após a 
preparação. Durante a adição do sal, as soluções foram vigorosamente agitadas a intervalos freqüentes. Depois deste processo, as soluções foram resfriadas à temperatura de $21^{\circ} \mathrm{C}$ e mantidas nesta temperatura por 48 horas.

As amostras foram preparadas, colocadas em redes de arame e imersas num recipiente com a solução de sulfato de sódio por um período de 16 horas, de modo que o nível da solução ficasse $1 \mathrm{~cm}$ acima da amostra, a uma temperatura de $21^{\circ} \mathrm{C}$ para manter a concentração da solução constante. Após este período, a amostra foi retirada da solução, drenada durante 15 minutos e colocada em estufa a $100^{\circ} \mathrm{C}$ para secar. $\mathrm{O}$ processo de imersão e secagem alternadas constitui um ciclo e, como citado anteriormente, foram realizados cinco ciclos para cada amostra.

Após completar o ciclo final e depois do resfriamento, das amostras, foram lavadas em solução de cloreto de bário a $10 \%$, para a retirada do excesso de sulfato de sódio.

O valor de durabilidade resulta da porcentagem da amostra que, após o ensaio, passa através da peneira na qual a fração inicial foi originariamente retida.

\subsection{ENSAIOO DE ADSORÇÃO DE AZUL DE METILENO PELO MÉTODO DA MANCHA}

Foram executados dois ensaios de adsorção de azul de metileno pelo método da mancha para cada amostra, segundo o método desenvolvido por FABBRI (1994), e determinou-se a média aritmética dos resultados dos ensaios.

\subsubsection{APARELHAGEM E MATERIAIS}

Para a execução do ensaio de adsorção de azul de metileno pelo método da mancha, são necessários os seguintes materiais: 
- peneira de malha quadrada de $\# 0,074 \mathrm{~mm}$;

- agitador magnético para soluções aquosas com possibilidade de regulagem do número de rotações;

- cronômetro, com resolução de segundos;

- baguete cilíndrica de vidro, com aproximadamente $8 \mathrm{~mm}$ de diâmetro e 250 mm de comprimento;

- bureta de vidro de $25 \mathrm{ml}$ de capacidade e graduada de $0,1 \mathrm{em} 0,1 \mathrm{ml}$;

- suporte para bureta;

- béquer de vidro com capacidade para $250 \mathrm{ml}$;

- provetas de vidro com capacidade 100 e $1000 \mathrm{ml}$;

- papel de filtro circular, com diâmetro entre 120 e 150 mm, para microcristais, com teor de cinzas inferior a $0,01 \%$, do tipo Reagen R-42, Whatman 42 ou similar;

- solução aquosa padrão de azul de metileno, com concentração de 1,0 g de sal anidro por litro de solução;

- água destilada.

\subsubsection{PREPARAÇÃO DA AMOSTRA}

A amostra de pó de rocha a ser ensaiada foi obtida dos finos produzidos no ensaio de desgaste de agregado por abrasão "Los Angeles" e passada na peneira de \#0,074 mm, pois o ensaio é realizado nesta fração granulométrica. Após o peneiramento, determina-se o teor de umidade (w) desta fração.

\subsubsection{EXECUÇÃO DO ENSAIO}

A execução do ensaio de adsorção de azul de metileno pelo método da mancha segue os seguintes procedimentos: 
a) pesar $1,00 \mathrm{~g}$ da fração de pó da rocha passado na \#0,074 $\mathrm{mm}$ e colocá-lo no bequer de $250 \mathrm{ml}$;

b) adicionar $100 \mathrm{ml}$ de água destilada ao bequer;

c) colocar o bequer contendo a suspensão pó de rocha + água destilada no agitador magnético;

d) através da bureta graduada, colocar no bequer 1,0 $\mathrm{ml}$ de solução padrão de azul de metileno e acionar o cronômetro, aguardando cerca de 1 minuto;

e) introduzir a baguete de vidro na suspensão, sem desligar o agitador magnético, capturar uma gota de suspensão e pingá-la em uma folha de papel de filtro;

f) observar a difusão da gota no papel de filtro. Deverá aparecer uma mancha circular, composta de um núcleo escuro que contém as partículas sólidas da suspensão (pó de rocha), circundada por uma borda de cor mais clara, correspondente à fase líquida da suspensão filtrada pelo papel de filtro (ver Figura 4.3.a);

- se houver, após a difusão da água, o aparecimento de uma aura azulada ou esverdeada em torno da borda que circunda o núcleo escuro da mancha (ver Figura 4.3.b), esperar por mais 3 minutos e repetir os itens e) e f). Se a aura persistir, após passados os 3 minutos (ver Figura 4.3.c), significa que há excesso de corante na solução e o ponto de viragem foi atingido;

- se não houver o aparecimento da aura, ou esta desaparecer após os 3 minutos de espera, repetir a operação a partir do item d), até que o teste da mancha persista por 3 minutos ou mais, conforme descrito acima;

g) anotar a quantidade de solução padrão de azul de metileno (V) correspondente ao ponto de viragem do teste de mancha, expressa $\mathrm{em} \mathrm{ml}$.

\subsubsection{RESULTADOS}

Sabendo-se a quantidade de solução padrão de azul de metileno adicionada à suspensão (V) e o teor de umidade da fração do pó de rocha ensaiada (w), calcula-se o valor de azul, conforme segue-se: 


$$
V_{\mathrm{a}}=\mathrm{V} \times\left(1+\frac{\mathrm{w}}{100}\right)
$$

onde:

$\mathrm{V}_{\mathrm{a}}$ : valor de azul, em mg de azul de metileno por g de amostra;

$\mathrm{V}$ : quantidade de solução padrão de azul de metileno $(\mathrm{ml})$, com concentração de 1,0 g por litro de solução;

w: teor de umidade da amostra (\%). 


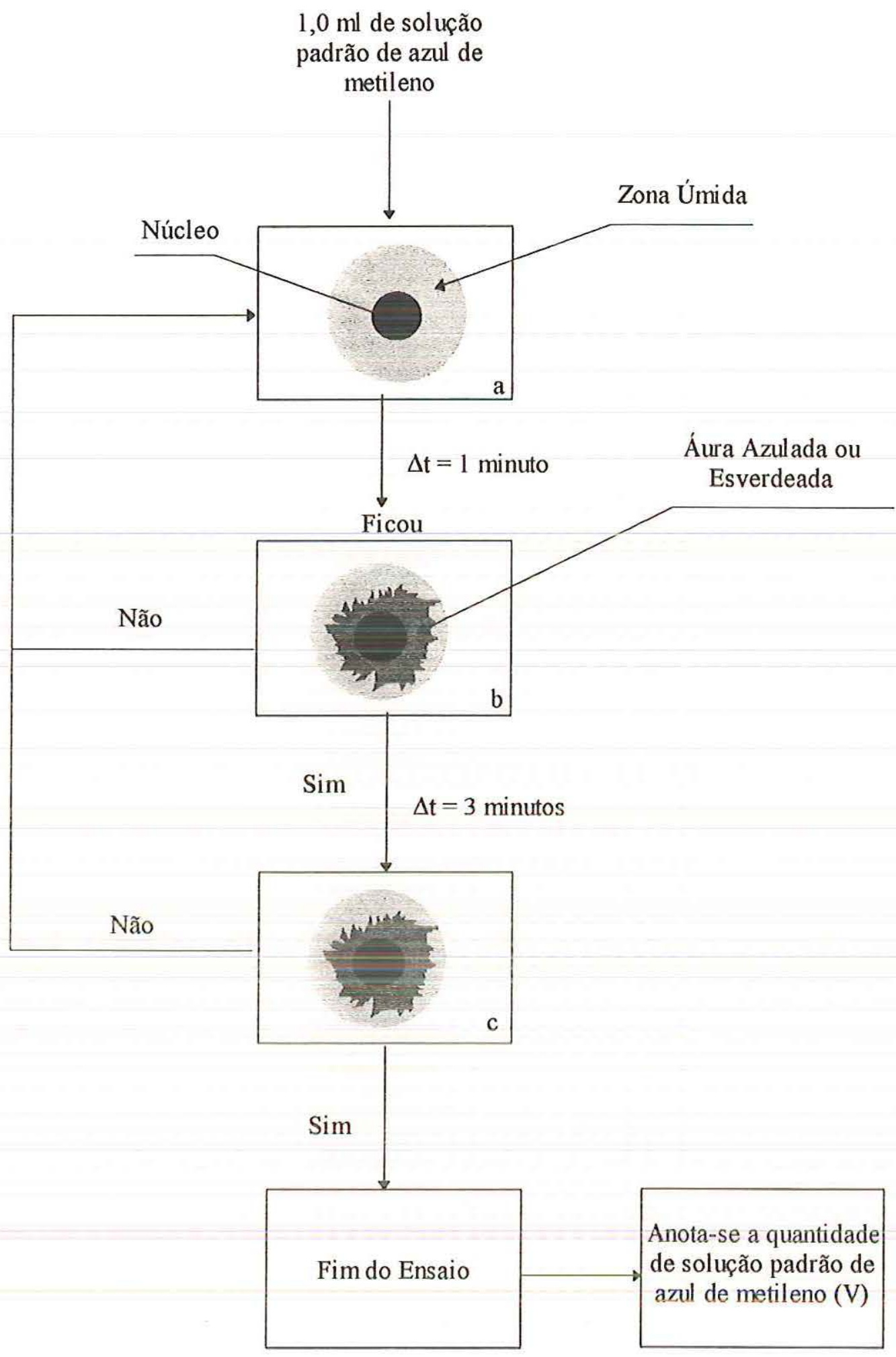

Figura 4.3 - Fluxograma do ensaio de adsorção de azul de metileno pelo método da mancha. 


\section{CAPÍTULO 5: APRESENTAÇÃO E DISCUSSÃO DOS RESULTADOS DA PESQUISA}

\subsection{INTRODUÇÃO}

Neste Capítulo são apresentados os resultados e as discussões dos ensaios analíticos, físico-mecânicos, de adesividade, de alteração e de adsorção de azul de metileno pelo método da mancha.

Inicialmente analisam-se os resultados obtidos para cada ensaio individualmente, comparando-os com os valores recomendados pela literatura. Dessa forma, avalia-se a aplicabilidade e a validade dos índices fornecidos para a previsão do comportamento dos materiais quando em serviço.

Em seguida, relaciona-se os resultados dos ensaios de adsorção de azul de metileno com os resultados dos ensaios físico-mecânicos e de alteração. Posteriormente, faz-se o confronto entre os resultados dos ensaios físico-mecânicos e de alteração entre si. Pretende-se, com isto, verificar a existência de relações entre os resultados dos ensaios físico-mecânicos, de alteração e de adsorção de azul de metileno pelo método da mancha. 


\subsection{DETERMINAÇÕES ANALÍTICAS}

\subsubsection{DIFRATOMETRIA DE RAIOS X}

Nas análises de raios $\mathrm{X}$ foi detectada a presença de piroxênio e feldspato em todas as nove amostras; nas amostras $1,2,3,4$ e 5 a presença de quartzo, nas amostras 6,8 e 10 a presença de magnetita e na amostra 4 a presença de esmectita, conforme apresentado no Anexo II.

As análises de difratometria de raios $\mathrm{X}$ indicaram a presença de argilo-minerais apenas na amostra 4. Este fato não significa que as demais amostras não contenham argilominerais pois, durante a interpretação dos difratogramas, leva-se em consideração somente os picos mais acentuados e é possível que se os argilo-minerais estiverem presentes em pequena quantidade, seus picos se apresentem pouco acentuados, não aparentando sua presença.

\subsubsection{ANÁLISES PETROGRÁFICAS MACROSCÓPICAS}

Todas as amostras analisadas macroscopicamente revelaram-se basaltos compactos com textura afanítica ${ }^{1}$.

\footnotetext{
${ }^{1}$ Rocha de granulação muito fina cujos constituintes minerais não podem ser distinguidos a olho nu.
} 
Os resultados da avaliação do estado de alteração e do grau de coerência das amostras obtidos através das análises petrográficas macroscópicas das amostras, são apresentados no Quadro 5.1.

Observando-se os resultados apresentados no Quadro 5.1 verifica-se que todas as amostras que apresentaram descoloração acentuada (amostras 2, 4 e 6) foram classificadas, segundo o IPT (1990), como medianamente alterada/medianamente coerente e muito alterada/incoerente. 
Quadro 5.1 - Descrição das características macroscópica e avaliação preliminar do estado de alteração e do grau de coerência de rochas.

\begin{tabular}{|c|c|c|}
\hline & Análise Macroscópica & \\
\hline Amostras - Local & Cor & IPT(1990) \\
\hline 1 - Santo Antonio $\left(C^{*}\right)$ & melanocrática (preta) & pouco alterada $\left(A_{2}\right)$ e coerente $\left(C_{1}\right)$ \\
\hline 2 - Santo Antonio $\left(A^{*}\right)$ & leucocrática (castanho-amarelada) & medianamente alterada $\left(A_{3}\right)$ e medianamente coerente $\left(C_{2}\right)$ \\
\hline 3 - Multipedras $\left(\mathbb{C}^{*}\right)$ & melanocrática (preto-esverdeada) & pouco alterada $\left(A_{2}\right)$ e coerente $\left(C_{1}\right)$ \\
\hline 4- Multipedras $\left(\mathbb{A}^{*}\right)$ & leucocrática (castanho-amarelada) & muito alterada $\left(\mathrm{A}_{4}\right)$ e incoerente $\left(\mathrm{C}_{4}\right)$ \\
\hline 5 - Ouro Fino $\left(C^{*}\right)$ & melanocrática (preta) & medianamente alterada $\left(A_{3}\right)$ e medianamente coerente $\left(C_{2}\right)$ \\
\hline 6 - Ouro Fino $\left(\mathbb{A}^{*}\right)$ & leucocrática (castanho-amarelada) & muito alterada $\left(\mathrm{A}_{4}\right)$ e incoerente $\left(\mathrm{C}_{4}\right)$ \\
\hline 7 - Bandeirantes $\left(C^{*}\right)$ & melanocrática (preto-acinzentada) & sã $\left(A_{1}\right)$ e coerente $\left(C_{1}\right)$ \\
\hline 8 - Bandeirantes $\left(A^{*}\right)$ & melanocrática (preta) & medianamente alterada $\left(A_{3}\right)$ e medianamente coerente $\left(C_{2}\right)$ \\
\hline 10 - Dois Córregos $\left(\mathrm{A}^{*}\right)$ & melanocrática (preta) & medianamente alterada $\left(A_{3}\right)$ e coerente $\left(C_{1}\right)$ \\
\hline
\end{tabular}

$\mathrm{C}^{*}=$ amostra de rocha comercializada; $\mathrm{A}^{*}=$ amostra de rocha alterada. 


\subsubsection{ANÁLISES PETROGRÁFICAS MICROSCÓPICAS}

De maneira geral, os basaltos da Formação Serra Geral apresentam minerais hidrotermais expansivos, que poderão segundo o estado microfissural da rocha sofrerem expansões por hidratação pelo acesso da água.

Durante a análise petrográfica microscópica das amostras observou-se a presença dos minerais que se encontram na constituição dos basaltos, como piroxênio e plagioclásio.

\subsection{ENSAIOS FÍSICO-MECÂNICOS E DENSIDADE REAL DE AGREGADO MIÚDO}

No Quadro 5.2 estão apresentados os resultados de Densidade real de agregado miúdo (método do picnômetro) e dos ensaios físico-mecânicos, tais como: Desgaste de agregado por abrasão "Los Angeles", Determinação do índice de tenacidade de agregados pelo aparelho Treton, Esmagamento e Avaliação da resistência mecânica de agregados pelo método dos $10 \%$ de finos . Analisa-se, a seguir, os resultados obtidos em cada ensaio. 
Quadro 5.2 - Resultados de densidade real de agregado miúdo (método do picnômetro) e dos ensaios físico-mecânicos.

\begin{tabular}{|c|c|c|c|c|c|}
\hline Ensaios & $\begin{array}{c}\text { Densidade Real } \\
\text { de Agregado } \\
\left(\mathrm{g} / \mathrm{cm}^{3}\right)\end{array}$ & $\begin{array}{l}\text { Desgaste de } \\
\text { Agregado por } \\
\text { Abrasão "Los } \\
\text { Angeles" } \\
(\%)\end{array}$ & $\begin{array}{c}\text { Determinação do } \\
\text { indice de tenacidade } \\
\text { de agregados pelo } \\
\text { aparellho Treton (\%) }\end{array}$ & $\begin{array}{c}\text { Esmagamento } \\
(\%)\end{array}$ & $\begin{array}{l}\text { Avaliação da Resistência } \\
\text { Mecânica de Agregados } \\
\text { pelo Método dos } 10 \% \text { de } \\
\text { Finos } \\
(\mathrm{kN})\end{array}$ \\
\hline 1 - Santo Antonio $\left(C^{*}\right)$ & 2,901 & 14,84 & 10,86 & 19,5 & 257,85 \\
\hline 2 - Santo Antonio $\left(\mathrm{A}^{*}\right)$ & 2,908 & 16,65 & 11,78 & 21,7 & 311,22 \\
\hline 3 - Multipedras $\left(C^{*}\right)$ & 2,911 & 16,17 & 12,38 & 22,95 & 207,95 \\
\hline 4 - Multipedras $\left(\mathbb{A}^{*}\right)$ & 2,839 & 13,76 & 11,52 & 25,86 & 256,46 \\
\hline 5 - Ouro Fino $\left(C^{*}\right)$ & 2,865 & 13,64 & 11,88 & 18,0 & 265,09 \\
\hline 6- Ouro Fino $\left(\mathrm{A}^{*}\right)$ & 2,879 & 17,65 & 15,70 & 20,44 & 235,54 \\
\hline 7 - Bandeirantes $\left(C^{*}\right)$ & 2,971 & 13,09 & 11,21 & 16,79 & 342,87 \\
\hline 8- Bandeirantes $\left(\mathbb{A}^{*}\right)$ & 2,924 & 18,25 & 12,72 & 16,10 & 249,60 \\
\hline 10 - Dois Córregos $\left(\mathbb{A}^{*}\right)$ & 2,913 & 21,34 & 15,08 & 19,65 & 211,01 \\
\hline
\end{tabular}

C* = amostra de rocha comercializada; $\mathrm{A}^{*}=$ amostra de rocha alterada. 


\subsubsection{DENSIDADE REAL DE AGREGADO MIÚdO - MÉTODO DO PICNÔMETRO}

Os valores de densidade real de agregado graúdo variaram entre $2,839 \mathrm{~g} / \mathrm{cm}^{3}$ e $2,971 \mathrm{~g} / \mathrm{cm}^{3}$, como pode-se observar na Figura 5.1 .

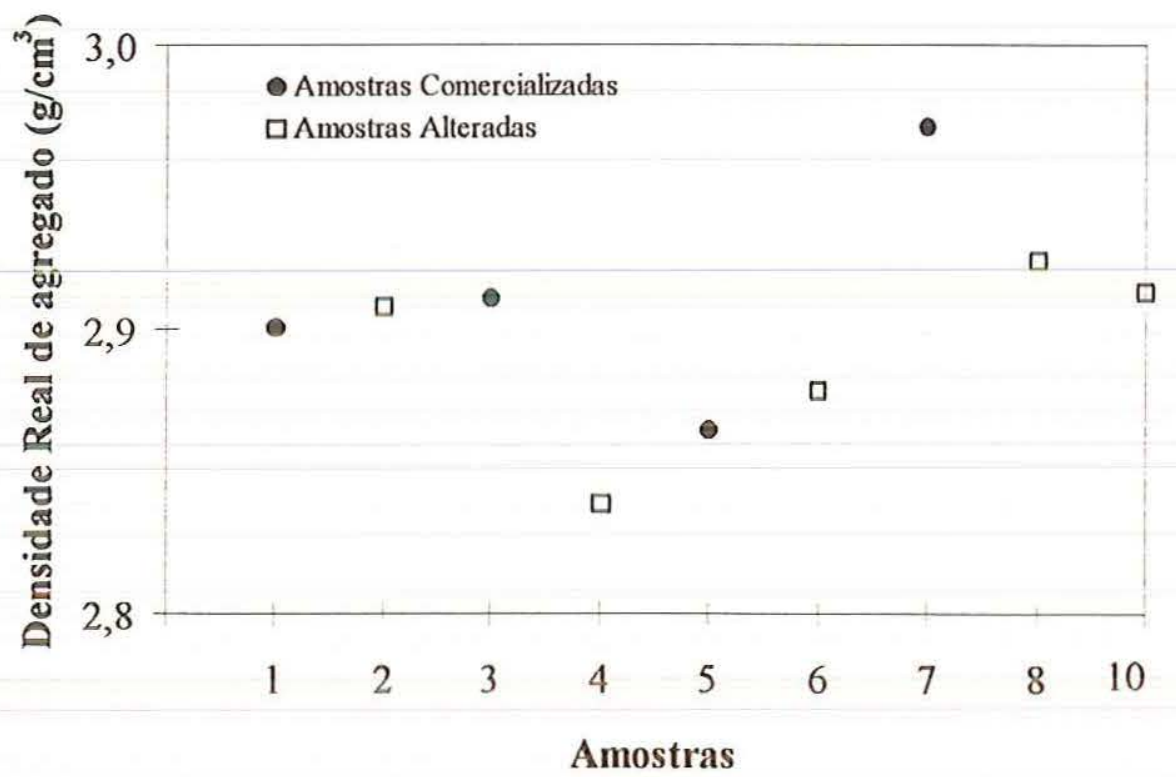

Figura 5.1 - Valores da densidade real de agregado miúdo.

\subsubsection{DESGAS̃TE DE AGREGADO POR ABRASÃO "LOS ANGELES"}

Os valores de desgaste de agregado por abrasão "Los Angeles", determinados pela média de três ensaios para cada amostra, variaram de $13,1 \%$ a $21,2 \%$. Observa-se que todas as amostras são utilizáveis para pavimentação, segundo este ensaio (valores $\leq$ 40\%, DER-SP (1991)), conforme mostrado na Figura 5.2. 
Entretanto, as amostras 2, 4, 6 e 8 são considerados materiais não aceitáveis. Isto indica que esse ensaio não deve ser utilizado sozinho na qualificação de agregados, pois é incapaz de identificar materiais com elevado grau de alteração e impróprios para utilização em pavimentação.

De acordo com os resultados, as amostras "comercializadas" apresentaram um desgaste por abrasão "Los Angeles" menor que as amostras "alteradas" para o mesmo local de origem, com exceção do par de amostras 3 e 4 .

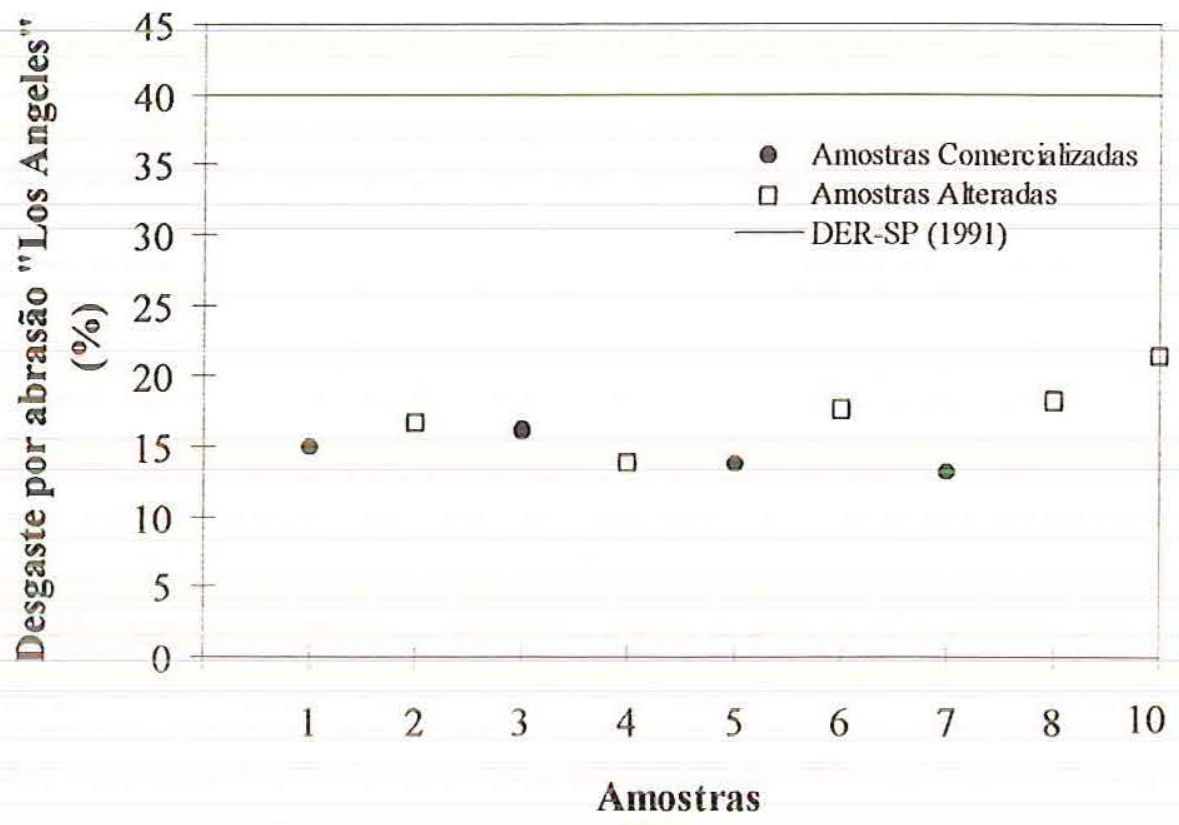

Figura 5.2 - Valores de Desgaste de agregado por abrasão "Los Angeles" e o valor máximo recomendado, segundo DER-SP (1991). 


\subsubsection{DETERMINAÇÃO DO ÍNDICE DE TENACIDADE DE AGREGADOS PELO APARELHO TRETON}

Os valores das perdas ao impacto Treton são apresentados na Figura 5.3. Analisandose esta figura pode-se perceber que as amostras "comercializadas" (1, 5 e 7) apresentaram "perdas" menores que seus respectivos pares "alteradas" (2, 6 e 8).

Comparando os resultados com o valor máximo recomendado para a perda de resistência ao impacto Treton (perdas $\leq 20 \%$, segundo FRAZÃO (1987)), verifica-se que todas as amostras seriam aceitáveis, indicando, também, que este ensaio não distingue materiais com maior ou menor grau de aiteração.

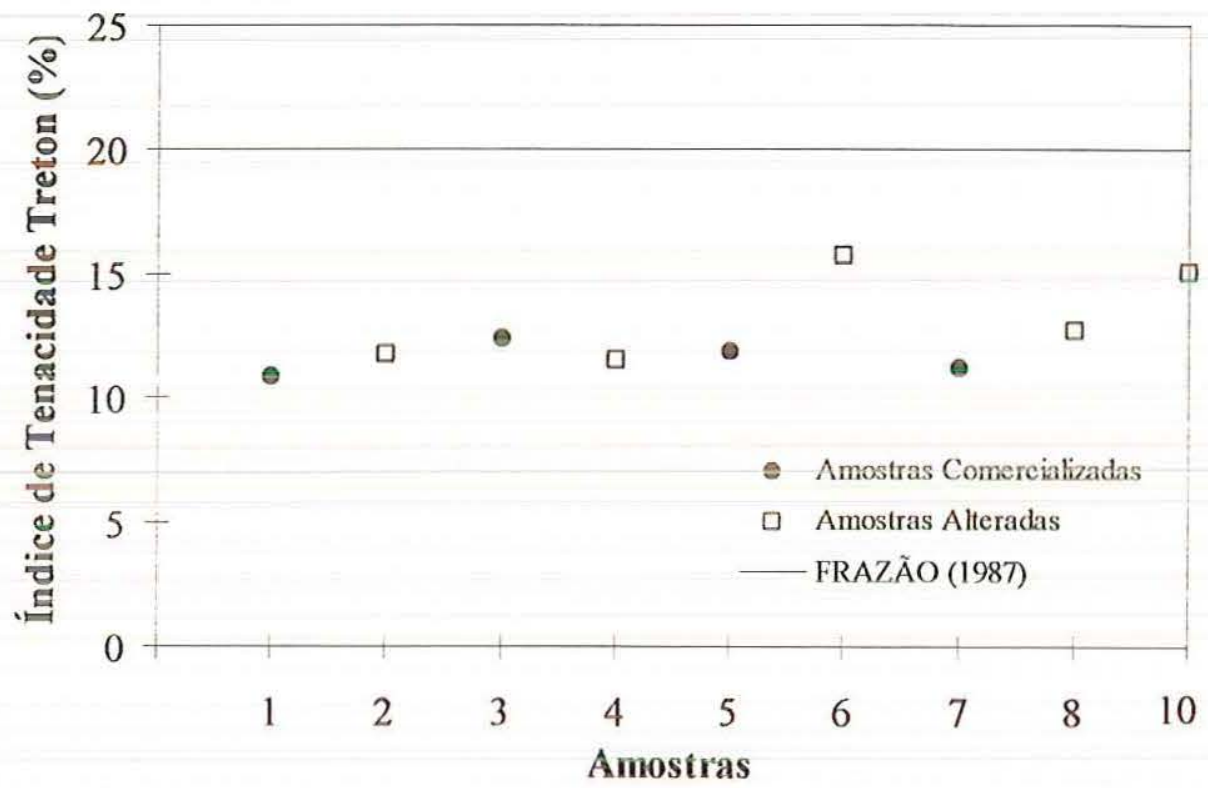

Figura 5.3 - Valores do índice de tenacidade Treton e o valor máximo recomendado, segundo FRAZÃO (1987). 


\subsubsection{ENSAIO DE ESMAGAMENTO}

Os valores das perdas de agregado ao esmagamento variaram de $16,1 \%$ a $25,9 \%$, abaixo, portanto, do limite recomendado segundo MACEDO et alii (1988) (valores $\leq$ $30 \%$ ), conforme mostrado na Figura 5.4 .

Comparando-se os valores obtidos para os agregados "comercializados" com os dos "alterados" de mesmo local de origem, verifica-se que a resistência ao esmagamento dos "comercializados" é superior à dos "alterados", com exceção das amostras 7 e 8, onde a amostra 7 ("comercializada") apresenta um valor ligeiramente maior do que o seu par "alterado".

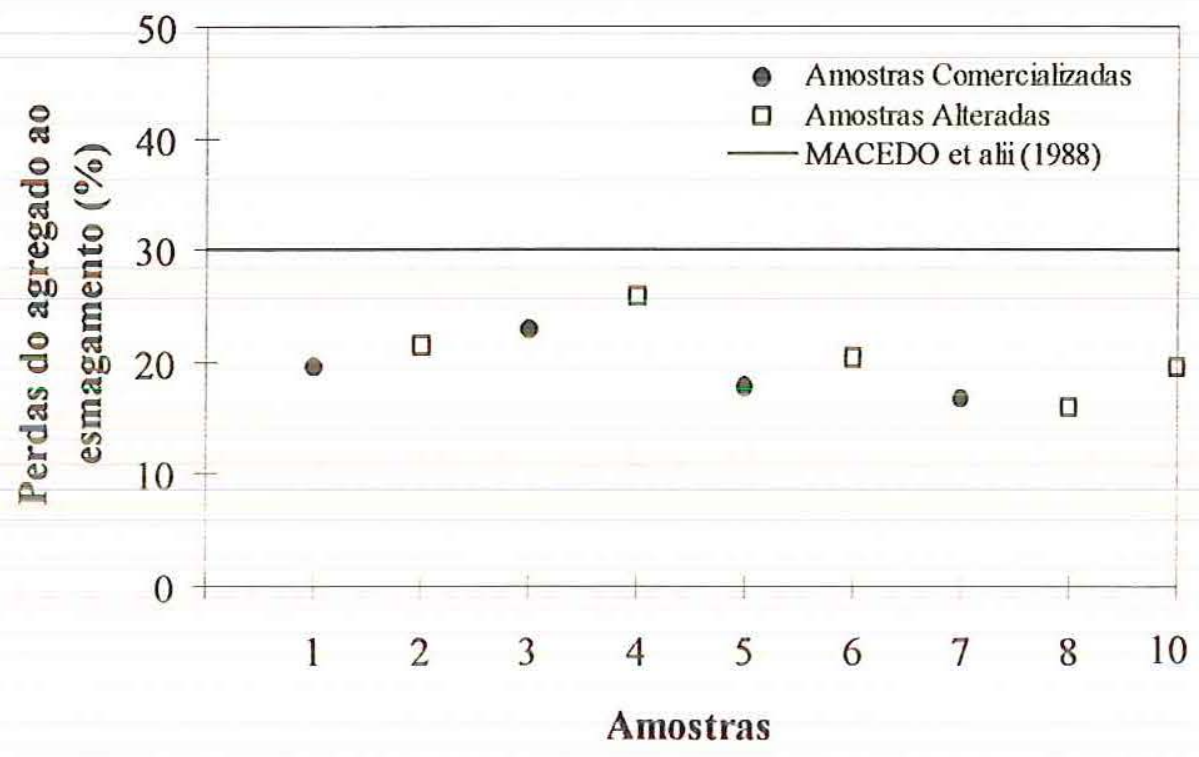

Figura 5.4 - Valores das perdas do agregado ao esmagamento e o valor máximo recomendado, segundo MACEDO et alii (1988). 


\subsubsection{AVALIAÇÃO DA RESISTÊNCIA MECÂNICA DE AGREGADOS PELO MÉTODO DOS $10 \%$ DE FINOS}

Os valores de resistência mecânica de agregado pelo método dos $10 \%$ de Finos variaram de $207,95 \mathrm{kN}$ a $342,87 \mathrm{kN}$, acima do mínimo exigido que, segundo MACEDO et alii (1988), deve ser $100 \mathrm{kN}$ para agregados quando utilizados em concretos sujeitos a desgastes superficiais e $50 \mathrm{kN}$ para outros concretos.

Observando-se a Figura 5.5, pode-se perceber que não há um comportamento homogêneo das amostras "comercializadas" em relação às "alteradas" para a resistência mecânica de agregado pelo método dos $10 \%$ de Finos. Nos pares (5 e 6$)$ e (7 e 8) as "comercializadas" apresentaram resistência mecânica superior às alteradas, enquanto que, para os pares ( 1 e 2) e (3 e 4) ocorreu o inverso, contrariando o previsto.

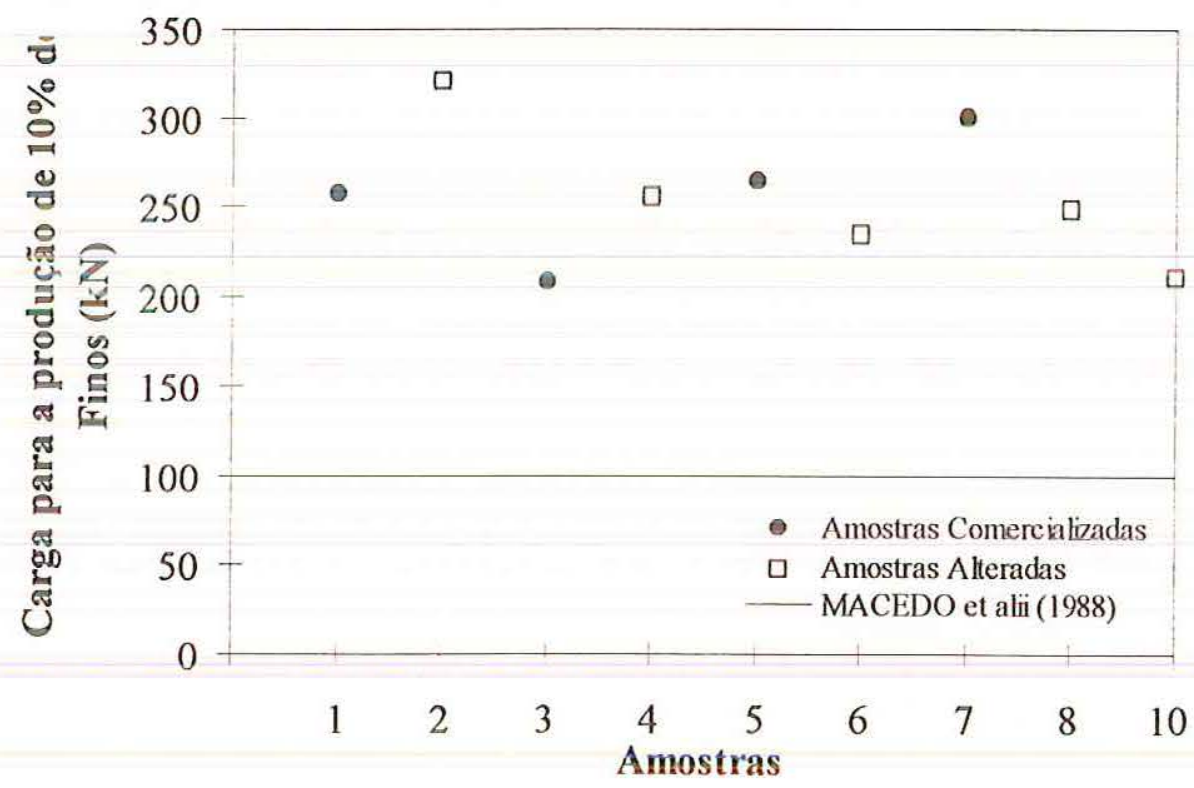

Figura 5.5 - Valores de resistência mecânica de agregado pelo método dos $10 \%$ de Finos e o valor máximo recomendado, segundo MACEDO et alii (1988). 


\subsection{ENSAIOS DE ADESIVIDADE DE AGREGADO A LIGANTE BETUMINOSO}

\subsubsection{ENSAIO DE ADESIVIDADE DE AGREGADO GRAÚDO A LIGANTE BETUMINOSO}

$\mathrm{Na}$ avaliação do ensaio de adesividade de agregado graúdo a ligante betuminoso, somente as amostras 3 e 7 apresentaram um comportamento satisfatório, conforme mostrado no Quadro 5.3. Durante a inspeção visual das amostras, segundo DNER ME 149-61, foi realizada uma estimativa do grau de descolamento da película betuminosa nas amostras e os resultados são apresentados também no Quadro 5.3.

Os resultados do ensaio de adesividade de agregado graúdo são apresentados no Anexo IV, por meio de fotos originais e coloridas do ensaio.

As amostras 3 e 7, como já foi dito, foram classificadas como satisfatórias pelo ensaio de adesividade de agregado graúdo, ou seja, não houve descolamento da película betuminosa.

As amostras restantes foram classificadas como insatisfatórias pelo ensaio de adesividade de agregado graúdo, onde foram observadas as presenças de bolhas de ar e de betume aderido às bordas dos béqueres, fatores que sugerem o descolamento da película betuminosa do agregado. Estes problemas podem ser observados, também, nas amostras 1 e 6, quando vistas pela parte superior (ver Anexo IV).

Nas fotografias apresentadas no Anexo IV pode-se observar também a aparência do par de amostras 7 e 8 (Figura IV.12), de um mesmo local de origem, submetidas ao ensaio de adesividade. Nesta fotografia percebe-se a diferença de aspecto quanto a adesividade da amostra "comercializada" para a "alterada". 
Quadro 5.3 - Resultados dos ensaios de adesividade de agregado graúdo a ligante betuminoso e estimativa do grau de descolamento da película betuminosa.

\begin{tabular}{|c|c|c|c|c|}
\hline Amostras & Procedência & $\begin{array}{c}\text { Denominação } \\
\text { na coleta }\end{array}$ & Classificação & $\begin{array}{c}\text { Grau de } \\
\text { descolamento }\end{array}$ \\
\hline 7 & Bandeirantes & \multirow[t]{2}{*}{ Comercializada } & \multirow[t]{2}{*}{ satisfatória } & \multirow{2}{*}{$\begin{array}{c}\text { menor } \\
\text { descolamento }\end{array}$} \\
\hline 3 & Multipedras & & & \\
\hline 10 & Dois Córregos & Alterada & & \\
\hline 1 & Santo Antonio & Comercializada & & \\
\hline 8 & Bandeirantes & \multirow[t]{2}{*}{ Alterada } & não & \\
\hline 4 & Multipedras & & \multirow[t]{4}{*}{ satisfatória } & \multirow{4}{*}{$\begin{array}{c}\text { maior } \\
\text { descolamento }\end{array}$} \\
\hline 5 & Ouro Fino & Comercializada & & \\
\hline 2 & Santo Antonio & \multirow[t]{2}{*}{ Alterada } & & \\
\hline 6 & Ouro Fino & & & \\
\hline
\end{tabular}

\subsubsection{ENSAIO DE ADESIVIDADE DE AGREGADO MUUDO A LIGANTE BETUMINOSO}

As amostras "comercializadas" (1, 3 e 5) foram classificadas como aceitáveis e todas as amostras "alteradas" apresentaram má adesividade, ocorrendo o deslocamento da película betuminosa na solução de água destilada, como mostra o Quadro 5.4.

Comparando-se os resultados dos dois ensaios de adesividade de agregado a ligante betuminoso, observa-se que: 
- a amostra 3 foi a única considerada satisfatória pelos dois métodos de adesividade de agregado;

- a amostra 7 apresentou um comportamento satisfatório pelo ensaio de adesividade de agregado graúdo a ligante betuminoso e não aceitável pelo ensaio de adesividade de agregado miúdo a ligante betuminoso.

Quadro 5.4-Resultados do ensaio de adesividade de agregado miúdo a ligante betuminoso.

\begin{tabular}{|c|c|c|c|c|}
\hline Amostras & Procedência & $\begin{array}{c}\text { Denominação } \\
\text { na coleta }\end{array}$ & Adesividade & Classificação \\
\hline 1 & Santo Antonio & Comercializada & $1-2$ & aceitável \\
\hline 2 & Santo Antonio & Alterada & 0 & má \\
\hline 3 & Multipedras & Comercializada & $3-4$ & aceitável-boa \\
\hline 4 & Multipedras & Alterada & 0 & má \\
\hline 5 & Ouro Fino & Comercializada & $2-3$ & aceitável \\
\hline 6 & Ouro Fino & Alterada & $0-1$ & má-aceitável \\
\hline 7 & Bandeirantes & Comercializada & $0-1$ & má-aceitável \\
\hline 10 & Bandeirantes & Alterada & 0 & má \\
\hline
\end{tabular}

As diferenças ocorridas nos resultados dos dois métodos de adesividade deve-se, possivelmente, ao fato de que no ensaio de adesividade de agregado graúdo os materiais são ensaiados com água destilada à temperatura de $40^{\circ} \mathrm{C}$ e no ensaio de adesividade de agregado miúdo, além da água destilada, os agregados ficam sujeitos 
ao ataque de soluções de carbonato de sódio $\left(\mathrm{Na}_{2} \mathrm{CO}_{4}\right)$ à temperatura de aproximada de $110^{\circ} \mathrm{C}$. Logo, o segundo ensaio produz efeitos mais severos em relação ao primeiro ensaio.

Entretanto, este fato não explica o que aconteceu com as amostras 1 e 5, que foram aceitas pelo ensaio de adesividade de agregado miúdo e não aceitas pelo de adesividade de agregado graúdo.

\subsection{ENSAIOS DE ALTERAÇÃO}

\subsubsection{ALTERAÇÃO POR LIXIVIAÇÃO CONTÍNUA COM EXTRATOR "SOXHLET" CONJUGADO COM DESGASTE DE AGREGADO POR ABRASÃO "LOS ANGELES"}

A alteração por lixiviação foi "medida" através da evolução do desgaste de agregado por abrasão "Los Angeles".

No Quadro 5.5 estão apresentados os resultados dos ensaios de alteração por lixiviação contínua com extrator "Soxhlet" para 10 e 40 ciclos conjugado com o ensaio de desgaste de agregado por abrasão "Los Angeles".

Os resultados revelaram que os desgastes aumentaram para as amostras 4, 6 e 8 à medida que o número de ciclos cresceu ( 0,10 e 40 ciclos), como mostra a Figura 5.6. Isto pode acontecer devido à expansão de argilo-minerais presentes na rocha quando em contato com a água. Desta forma, as pressões causam uma desestruturação da rocha e uma conseqüente diminuição da resistência mecânica. Já para as amostras 2 e 
10 aconteceu o inverso, ou seja, os desgastes diminuíram com o aumento do número de ciclos.

Quadro 5.5 - Resultados dos ensaios de alteração por lixiviação contínua com extrator "Soxhlet" para 10 e 40 ciclos conjugado com desgaste de agregado por abrasão "Los Angeles".

\begin{tabular}{|c|c|c|c|c|}
\hline Amostras & Procedência & $\begin{array}{c}\text { Abrasão "Los } \\
\text { na coleta }\end{array}$ & $\begin{array}{c}\text { Abrasão "Los } \\
\text { Angeles" após } \\
\text { lixiviação } \\
\text { Angeles" após } \\
\text { lixiviação }\end{array}$ \\
\hline 1 & Santo Antonio & (\%) & (40 ciclos) (\%) \\
\hline 2 & Santo Antonio & Alterada & 16,20 & 14,64 \\
\hline 3 & Multipedras & Comercializada & 15,76 & 13,04 \\
\hline 4 & Multipedras & Alterada & 24,86 & 28,86 \\
\hline 5 & Ouro Fino & Comercializada & 16,44 & 15,60 \\
\hline 6 & Ouro Fino & Alterada & 22,04 & 25,06 \\
\hline 7 & Bandeirantes & Comercializada & 13,94 & 11,28 \\
\hline 8 & Bandeirantes & Alterada & 20,26 & 24,92 \\
\hline 10 & Dois Córregos & Alterada & 19,48 & 18,58 \\
\hline
\end{tabular}

Analisando-se, ainda, a Figura 5.6 verifica-se que as amostras "comercializadas" (1, 5 e 7) apresentaram um aumento do desgaste por abrasão com o crescimento de 0 para 10 ciclos e posteriormente uma diminuição do desgaste de 10 para 40 ciclos. Já para a amostra 3, os desgaste diminuíram com o aumento do número de ciclos. 


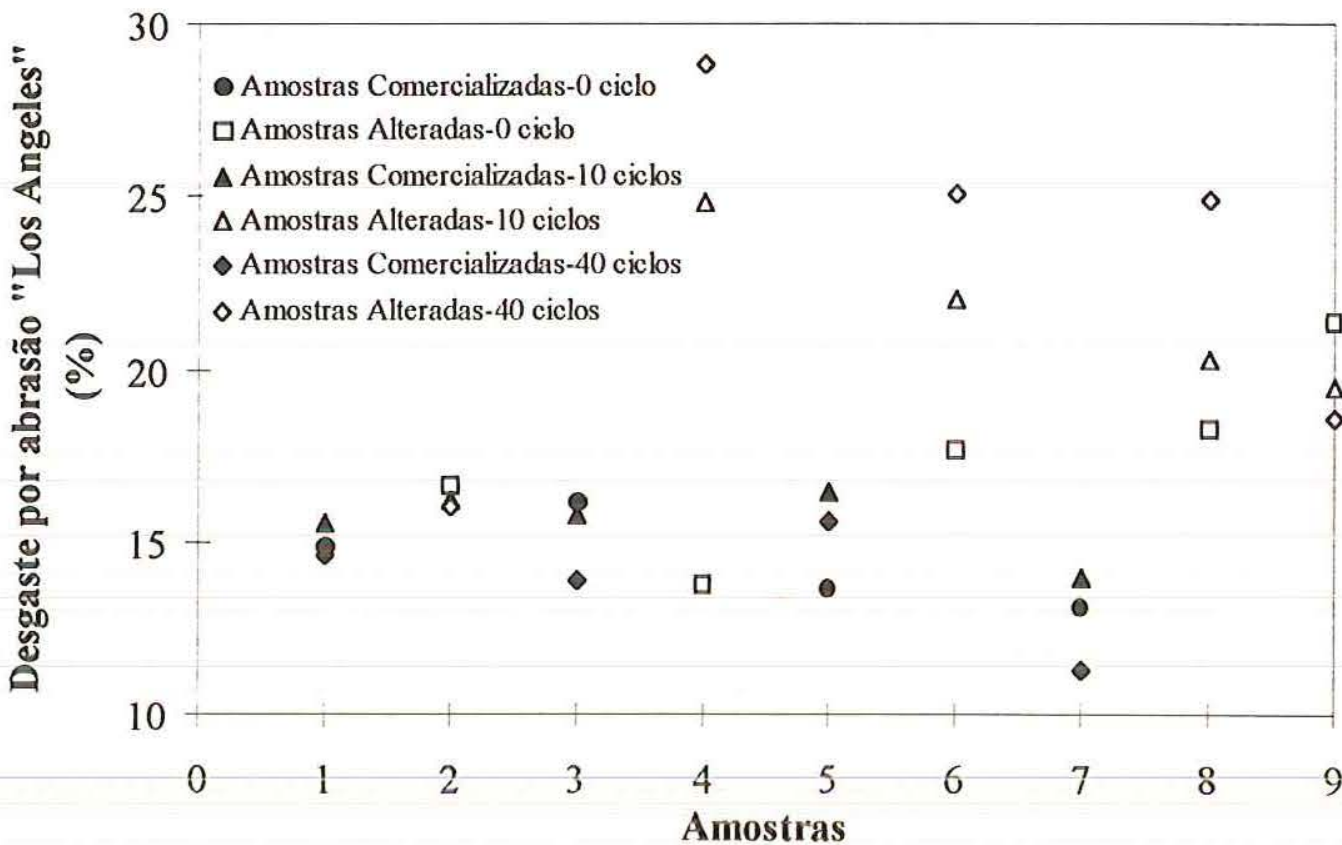

Figura 5.6 - Valores de desgaste de agregado por abrasão "Los Angeles" após o ensaio de alteração por lixiviação contínua para 0, 10 e 40 ciclos.

No Quadro 5.6 são apresentadas as análises químicas realizadas nas soluções resultantes do ensaio de lixiviação contínua dos agregados, para dosagens dos elementos $\mathrm{Ca}^{+2}, \mathrm{Mg}^{+2}, \mathrm{~K}^{+}$e $\mathrm{Na}^{+}$.

Observa-se, analisando-se o Quadro 5.6, que na maioria das amostras houve um crescimento do número de íons alcalinos e alcalino-terrosos $\left(\mathrm{Ca}^{+2}, \mathrm{Mg}^{+2}, \mathrm{~K}^{+}\right.$e $\left.\mathrm{Na}^{+}\right)$ lixiviados, modificando a composição química da água original para os 10 e 40 ciclos. Estes resultados indicam, possivelmente, que as rochas não se encontram num processo de alteração para este número de ciclos. 
Quadro 5.6 - Análise química da água utilizada no ensaio de lixiviação contínua com extrator "Soxhlet".

\begin{tabular}{|c|c|c|c|c|c|}
\hline Ciclos & Amostras & $\begin{array}{l}\text { Cálcio } \\
(\mathrm{mg} / \mathrm{l})\end{array}$ & $\begin{array}{c}\text { Magnésio } \\
(\mathrm{mg} / \mathrm{l})\end{array}$ & $\begin{array}{l}\text { Sódio } \\
(\mathrm{mg} / \mathrm{l})\end{array}$ & $\begin{array}{c}\text { Potássio } \\
\text { (mg/l) }\end{array}$ \\
\hline & Água destilada & 0,07 & 0,04 & N.D." & N.D." \\
\hline \multirow{9}{*}{10} & 1 & 0,14 & 0,16 & 8,50 & 2,00 \\
\hline & 2 & 0,22 & 0,27 & 4,80 & 3,30 \\
\hline & 3 & 0,11 & 0,09 & 5,60 & 3,80 \\
\hline & 4 & 0,11 & 0,33 & 12,00 & 8,30 \\
\hline & 5 & 0,18 & 0,29 & 6,40 & 4,50 \\
\hline & 6 & 0,10 & 0,16 & 3,50 & 2,30 \\
\hline & 7 & 0,59 & 0,23 & 7,40 & 5,30 \\
\hline & 8 & 0,24 & 0,16 & 9,60 & 6,50 \\
\hline & 10 & 1,24 & 0,26 & 9,30 & 6,30 \\
\hline \multirow{9}{*}{40} & 1 & 0,39 & 0,07 & 24,00 & 6,50 \\
\hline & 2 & 0,23 & 0,15 & 10,50 & 3,50 \\
\hline & 3 & 0,22 & 0,18 & 21,00 & 4,50 \\
\hline & 4 & 0,10 & 0,24 & 20,00 & 13,50 \\
\hline & 5 & 0,14 & 0,15 & 20,50 & 11,80 \\
\hline & 6 & 0,13 & 0,17 & 6,00 & 2,30 \\
\hline & 7 & 1,51 & 0,06 & 12,50 & 10,00 \\
\hline & 8 & 0,87 & 0,07 & 20,50 & 23,50 \\
\hline & 10 & 1,12 & 0,11 & 20,50 & 8,00 \\
\hline
\end{tabular}

*N.D.: não detectado

Através da dosagem dos elementos $\mathrm{Ca}^{+2}, \mathrm{Mg}^{+2}, \mathrm{~K}^{+}$e $\mathrm{Na}^{+}$, calculou-se o índice de proporções de metais alcalinos e alcalino-terrosos presentes em cada amostra, conforme apresentado no Quadro 5.7. 
Quadro 5.7 - Índice de proporções de metais alcalinos e alcalino-terrosos (I).

\begin{tabular}{|c|c|c|c|c|c|}
\hline Ciclos & Amostras & I* & Ciclos & Amostras & $I^{*}$ \\
\hline \multirow{9}{*}{10} & 1 & 0,127 & \multirow{9}{*}{40} & 1 & 0,366 \\
\hline & 2 & 0,087 & & 2 & 0,167 \\
\hline & 3 & 0,108 & & 3 & 0,308 \\
\hline & 4 & 0,236 & & 4 & 0,388 \\
\hline & 5 & 0,127 & & 5 & 0,376 \\
\hline & 6 & 0,068 & & 6 & 0,989 \\
\hline & 7 & 0,149 & & 7 & 0,263 \\
\hline & 8 & 0,187 & & 8 & 0,498 \\
\hline & 10 & 0,185 & & 10 & 0,341 \\
\hline
\end{tabular}

*I = Índice de Proporções de Metais Alcalinos e Alcalino-terrosos.

Os índices de proporções de metais alcalinos e alcalino-terrosos, apresentados no Quadro 5.7, progrediram com o aumento do número de ciclos, ou seja, para as condições que foram realizados os ensaios, o índice apenas indicou o enriquecimento temporário destes elementos.

Para melhor visualização, os índices de proporções de metais alcalinos e alcalinoterrosos estão apresentados, em forma de gráfico, na Figura 5.7. Observando-se esta figura nota-se que, para 10 ciclos, as amostras "comercializadas" ( 1 e 5 ) apresentaram indices maiores que seus respectivos pares "alterados" (2 e 6), enquanto que para os outros dois pares (( 3 e 4) e (7 e 8)) o comportamento foi o inverso, ou seja, os índices das "comercializadas" foi inferior ao das "alteradas".

Analisando-se esta mesma figura para 40 ciclos, percebe-se que a maioria das amostras "comercializadas" apresentaram índices menores que os dos seus respectivos 
pares. Deve-se notar ainda que a amostra 5, que apresentava índice maior que seu par para 10 ciclos, passou a apresentá-lo menor para 40 ciclos, indicando, possivelmente, início do processo de intemperismo químico (simulado).

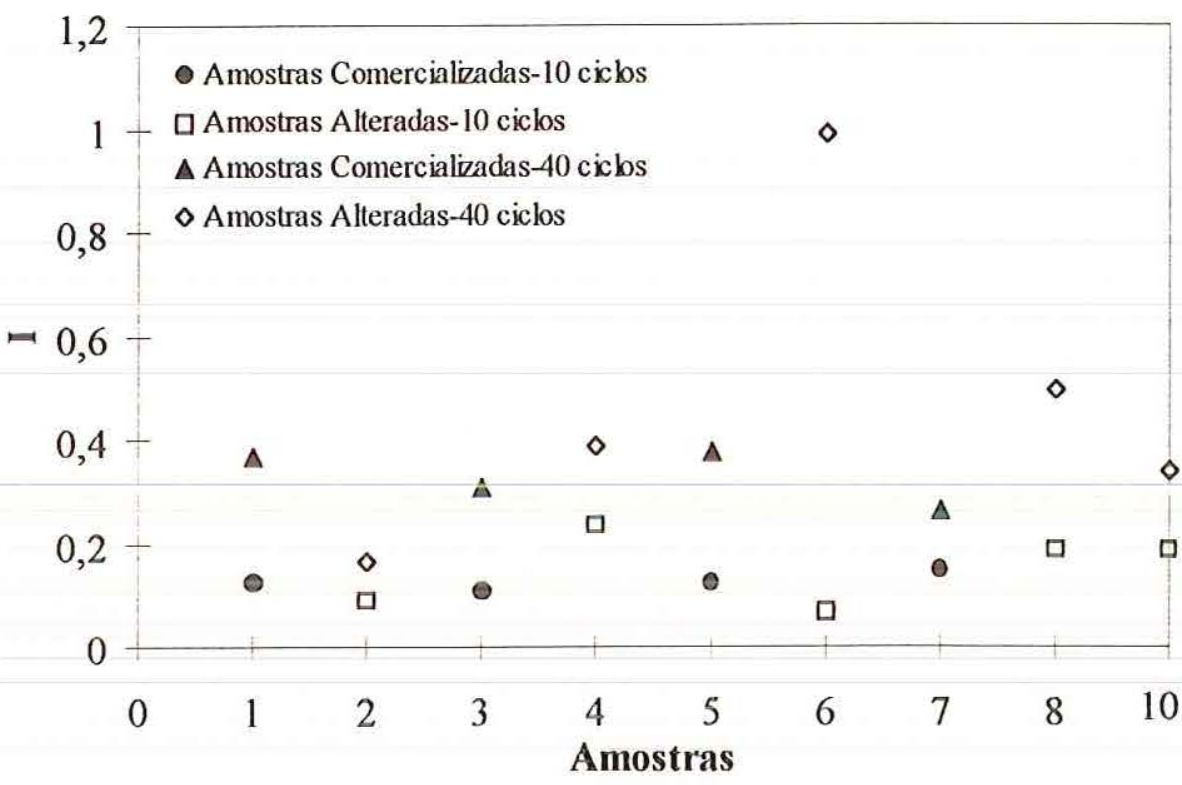

Figura 5.7 - Valores dos índices de proporções de metais alcalinos e alcalino-terrosos (I), para 10 e 40 ciclos.

\subsubsection{AVALIAÇÃO DA DURABILIDADE DE AGREGADOS PELO EMPREGO DE SOLUÇÕES DE SULFATO DE SÓDIO}

Os resultados do ensaio de avaliação da durabilidade de agregados pelo emprego de soluções de sulfato de sódio são apresentados no Quadro 5.8 e na Figura 5.8. 
Quadro 5.8 - Resultados do ensaio de avaliação da durabilidade de agregados pelo emprego de soluções de sulfato de sódio.

\begin{tabular}{|c|c|c|c|}
\hline Amostras & Procedência & $\begin{array}{c}\text { Denominação na } \\
\text { coleta }\end{array}$ & $\begin{array}{c}\text { Avaliação da Durabilidade } \\
\text { ao Sulfato de Sódio } \\
\text { (\%) }\end{array}$ \\
\hline 1 & Santo Antonio & Comercializada & 11,20 \\
\hline 2 & Santo Antonio & Alterada & 13,00 \\
\hline 3 & Multipedras & Comercializada & 17,20 \\
\hline 4 & Multipedras & Alterada & 41,40 \\
\hline 5 & Ouro Fino & Comercializada & 14,00 \\
\hline 6 & Ouro Fino & Alterada & 27,90 \\
\hline 7 & Bandeirantes & Comercializada & 11,10 \\
\hline 8 & Bandeirantes & Alterada & 26,90 \\
\hline 10 & Dois Córregos & Alterada & 9,40 \\
\hline
\end{tabular}

Observa-se que cerca de $67 \%$ das amostras apresentaram perdas inferiores ao especificado pela norma (valores $\leq 20 \%$, DER-SP(1991)), conforme mostrado na Figura 5.8. Destas, apenas duas, as amostras 2 e 10, são consideradas "alteradas". As demais amostras "alteradas" apresentaram perdas superiores a $20 \%$ (entre $26,9 \%$ e $41,4 \%$ ), indicando um maior grau de intemperismo sofrido.

Neste ensaio é interessante notar que a amostra 10 apresentou uma tendência para menores perdas em relação as outras amostras "alteradas" e também apresenta menores características visuais de alteração, conforme já comentado no Capítulo 3. 


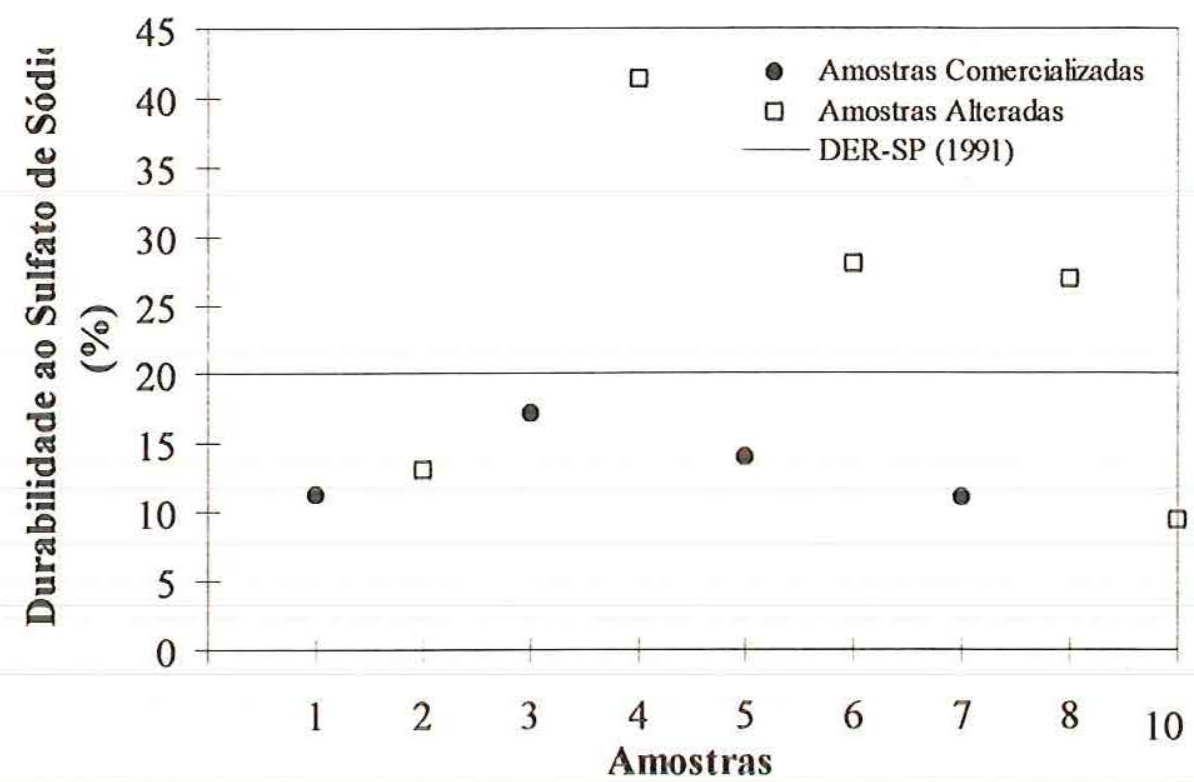

Figura 5.8 - Valores de Avaliação da durabilidade de agregados pelo emprego de soluções de sulfato de sódio e valor máximo recomendado, segundo DER-SP (1991).

\subsection{ENSAIO DE ADSORÇ̃O DE AZUL DE METLLENO PELO MÉTODO DA MANCHA}

Os resultados dos ensaios de adsorção de azul de metileno pelo método da mancha, expressos em termos dos valores de azul (Va, Fórmula 4.4), são apresentados no Quadro 5.9 e na Figura 5.9. Observando-se estes resultados pode-se verificar que, para amostras de mesma origem, as "comercializadas" apresentaram consumo de corante ou superficie específica inferior às "alteradas".

Este fato revela que o valor de azul dever estar indicando a presença de argilominerais nas amostras "alteradas", ou a presença de microfissuramento mais 
acentuado ou a diferença de distribuição granulométrica ou ainda o conjunto destes fatores.

Considerando que os ensaios de raios $\mathrm{X}$ não indicaram a presença significativa de argilo-minerais nas amostras e que a hipótese de haver microfissuramento nas frações utilizadas no ensaio de adsorção de azul de metileno é improvável, resolveu-se investigar possíveis diferenças granulométricas das frações utilizadas nos ensaios de adsorção.

Para tanto, foram executados ensaios de sedimentação nas frações das amostras utilizadas para a adsorção de azul de metileno e resultantes dos ensaios de desgaste de agregado por abrasão "Los Angeles".

A partir das curvas de distribuição granulométrica, obtidas dos ensaios de sedimentação, e admitindo-se que as partículas são aproximadamente esféricas, calculou-se a "área" aproximada de cada uma das amostras (ver Anexo III).

De posse dos valores das "áreas" aproximadas das amostras construiu-se o gráfico apresentado na Figura 5.10. Nela as "área" aproximadas são lançadas contra os valores de azul para cada amostra.

Observando-se a Figura 5.10 pode-se notar que a amostra 10 , que teve um consumo baixo de corante apresenta uma área, conforme calculado, também baixa, portanto de acordo com o esperado, uma vez que seu aspecto é de rocha de boa qualidade, a menos da presença de "vidro" em sua constituição.

Por outro lado pode-se observar também o seguinte comportamento: quanto maior a área da amostra (calculada) maior o valor de azul, ou seja, maior o consumo de corante. Nos casos onde as áreas calculadas são similares (amostras "comercializadas" e "alteradas"), as diferenças de consumo podem realmente estar associadas à presença de materiais deletérios. 
Assim sendo, parece que o consumo de corante, ou seja, o valor de azul, para as amostras estudadas, está intimamente ligado à distribuição granulométrica e à presença de argilo-minerais. Para quase todos os pares de amostras (exceção (5 e 6)), as amostras "alteradas" submetidas ao ensaio de desgaste por abrasão "Los Angeles", produziram uma maior quantidade de finos.

Analisando-se, ainda, a Figura 5.10, percebe-se que existe uma separação entre as amostras "comercializadas" e as "alteradas", para um valor de azul (Va) aproximado de $12,5 \mathrm{mg} / \mathrm{g}$.

Quadro 5.9 - Resultados do ensaio de adsorção de azul de metileno pelo método da mancha.

\begin{tabular}{|c|c|c|c|}
\hline Amostras & Procedência & Denominação na coleta & Va (mg/g) \\
\hline 1 & Santo Antonio & Comercializada & 9,43 \\
\hline 2 & Santo Antonio & Alterada & 17,71 \\
\hline 3 & Multipedras & Comercializada & 11,82 \\
\hline 4 & Multipedras & Alterada & 20,39 \\
\hline 5 & Ouro Fino & Comercializada & 11,01 \\
\hline 6 & Ouro Fino & Alterada & 13,78 \\
\hline 7 & Bandeirantes & Comercializada & 4,57 \\
\hline 8 & Bandeirantes & Alterada & 12,92 \\
\hline 10 & Dois Córregos & Alterada & 5,77 \\
\hline
\end{tabular}




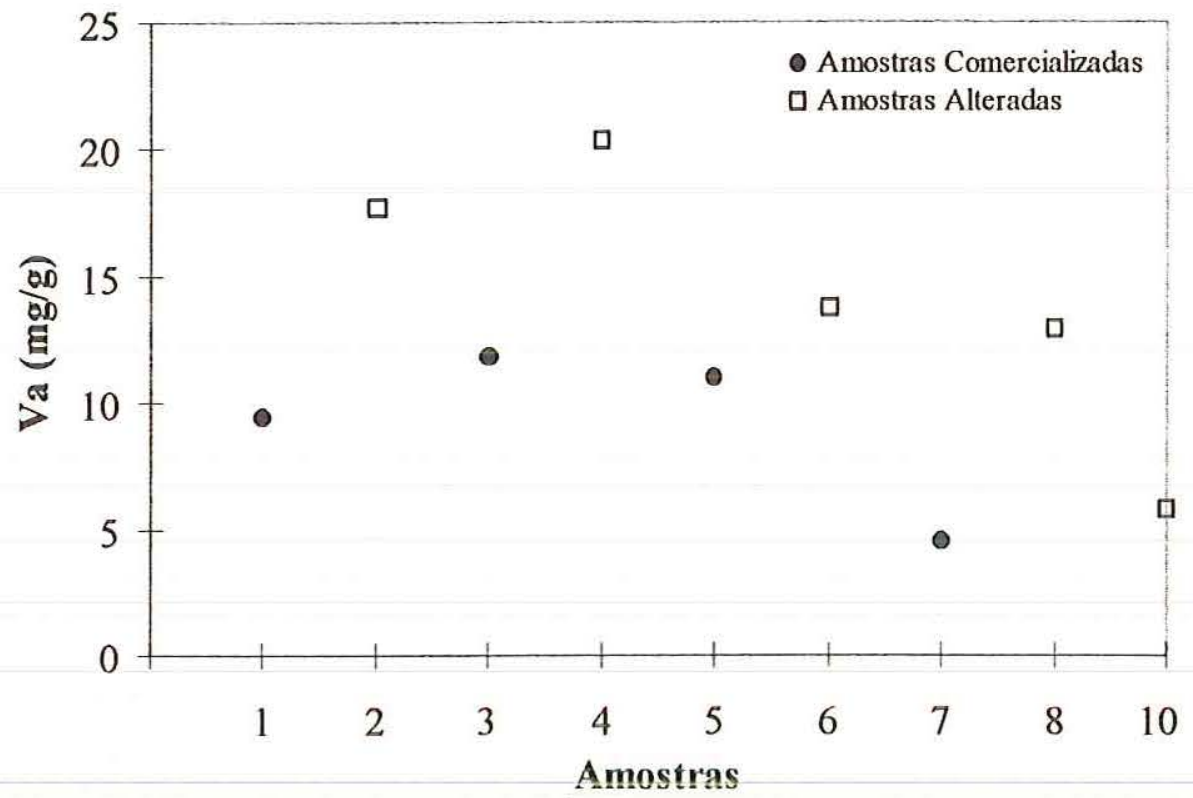

Figura 5.9 - Valores de azul de metileno (Va).

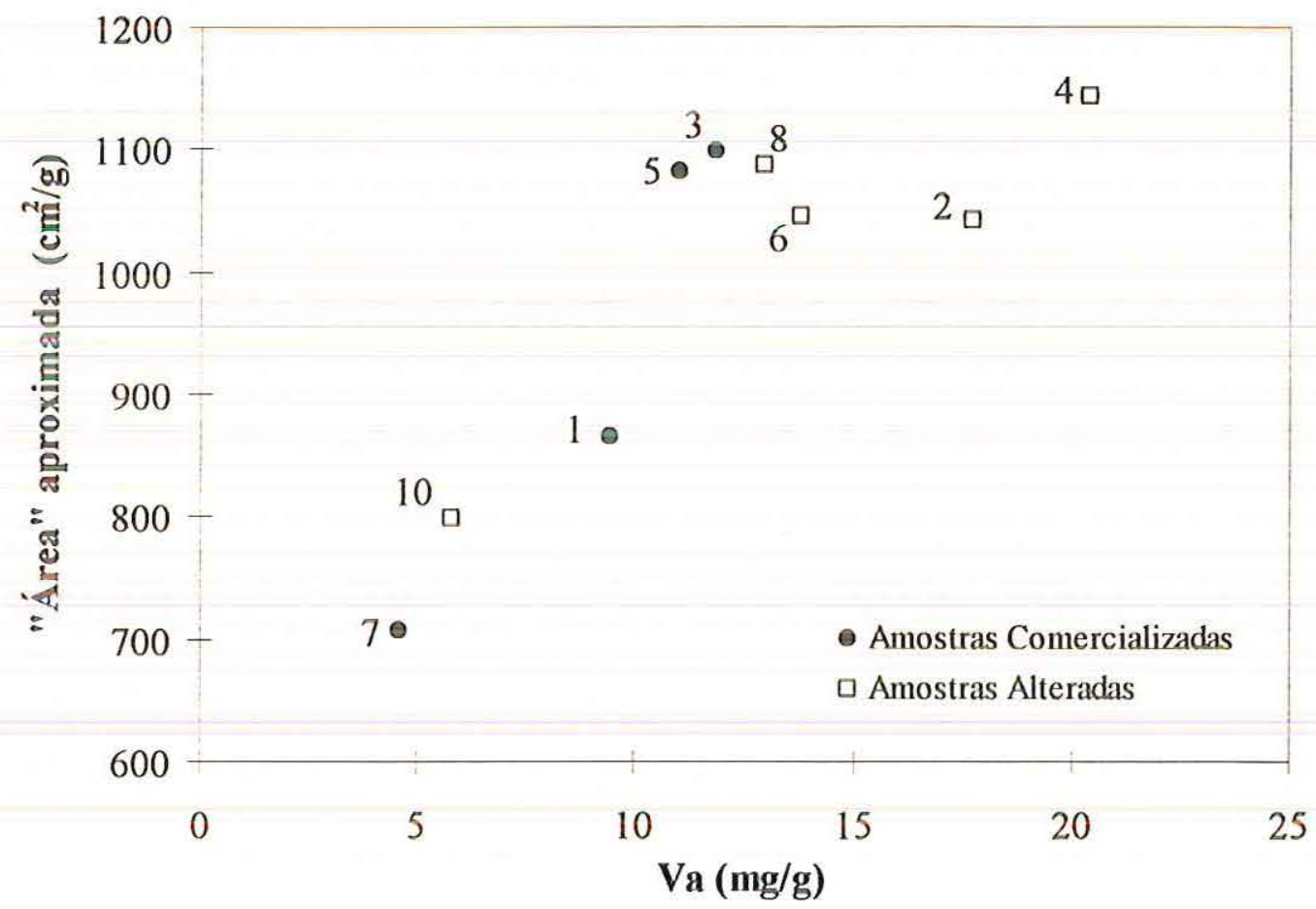

Figura 5.10 - Valor de azul (Va) versus "área" aproximada da "fração fina" da rocha. 


\subsection{DISCUSSÃO DOS RESULTADOS DO ENSAIO DE ADSORÇÃO DE AZUL DE METILENO PELO MÉTODO DA MANCHA VERSUS OUTROS ENSAIOS}

Nos próximos itens os resultados do ensaio de adsorção de azul de metileno pelo método da mancha, expressos em termos dos valores de azul (Va, Expressão 4.4), são confrontados com os resultados obtidos dos ensaios físico-mecânicos e de alteração.

Para se tentar estabelecer relações coerentes, primeiramente comparam-se resultados da adsorção de azul de metileno para amostras "comercializadas" com resultados de outros ensaios, também obtidos para amostras "comercializa das", procedendo-se da mesma forma para as amostras "alteradas". Assim, trabalha-se com "universos" mais homogêneos do ponto de vista da caracterização macroscópica.

Posteriormente, os resultados são comparados para o conjunto de amostras estudados ("comercializadas" e "alteradas").

Foram efetuadas também análise de regressão linear para estas comparações realizadas entre os resultados das amostras e com a apresentação do valor do coeficiente de correlação $\left(R^{2}\right)$, quando mostrou-se satisfatório $\left(R^{2}>0,5\right)$.

\subsubsection{VALOR DE AZUL (VA) VERSUS RESULTADOS DOS ENSAIOS FÍSICO-MECÂNICOS}

Nas Figuras 5.11 a 5.14 são apresentados os valores de azul versus os valores dos ensaios físico-mecânicos. 
A Figuras 5.11 mostra a relação entre ensaio de adsorção de azul de metileno pelo método da mancha e o de desgaste de agregado por abrasão "Los Angeles".

Observando-se esta figura nota-se que as amostras "comercializadas" apresentam uma relação direta com um coeficiente de correlação de 0,50 . Nota-se também que existe uma concordância, ainda para as amostras "comercializadas", entre os resultados destes dois tipos de ensaios pois, para um aumento no valor de azul (Va), há um decréscimo correspondente na resistência à abrasão, ou seja, a perda no ensaio de desgaste de agregado por abrasão aumenta.

Já para as amostras "alteradas", a relação é inversa e o coeficiente de correlação é igual a 0,96 . Neste caso, não se verifica o esperado, isto é, para um aumento do Va não ocorre um aumento do desgaste à abrasão e sim uma diminuição da "perda".

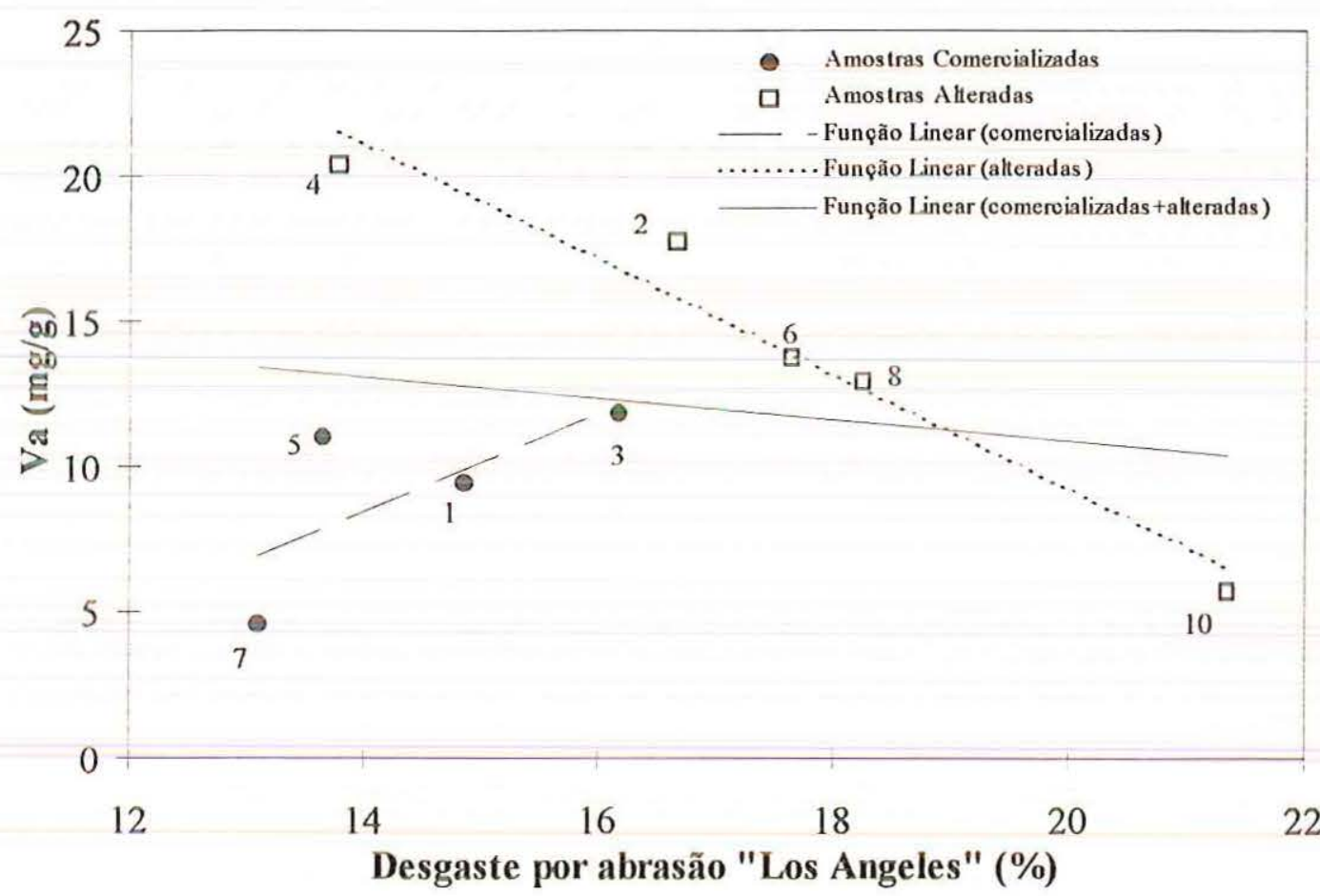

Figura 5.11 - Valores de azul versus valores de desgaste de agregado por abrasão "Los Angeles". 
Observando-se ainda a Figura 5.11 pode-se verificar também que não há relação clara entre o valor de azul (Va) e o desgaste a abrasão "Los Angeles" para o conjunto de amostras pois, como já foi dito, a relação obtida para as amostras "comercializadas" varia de forma contrária à obtida para as amostras "alteradas", o que impede que haja uma relação coerente para o conjunto das amostras.

A Figura 5.12 apresenta a relação entre o ensaio de adsorção de azul de metileno pelo método da mancha e o de determinação do índice de tenacidade de agregados pelo aparelho Treton.

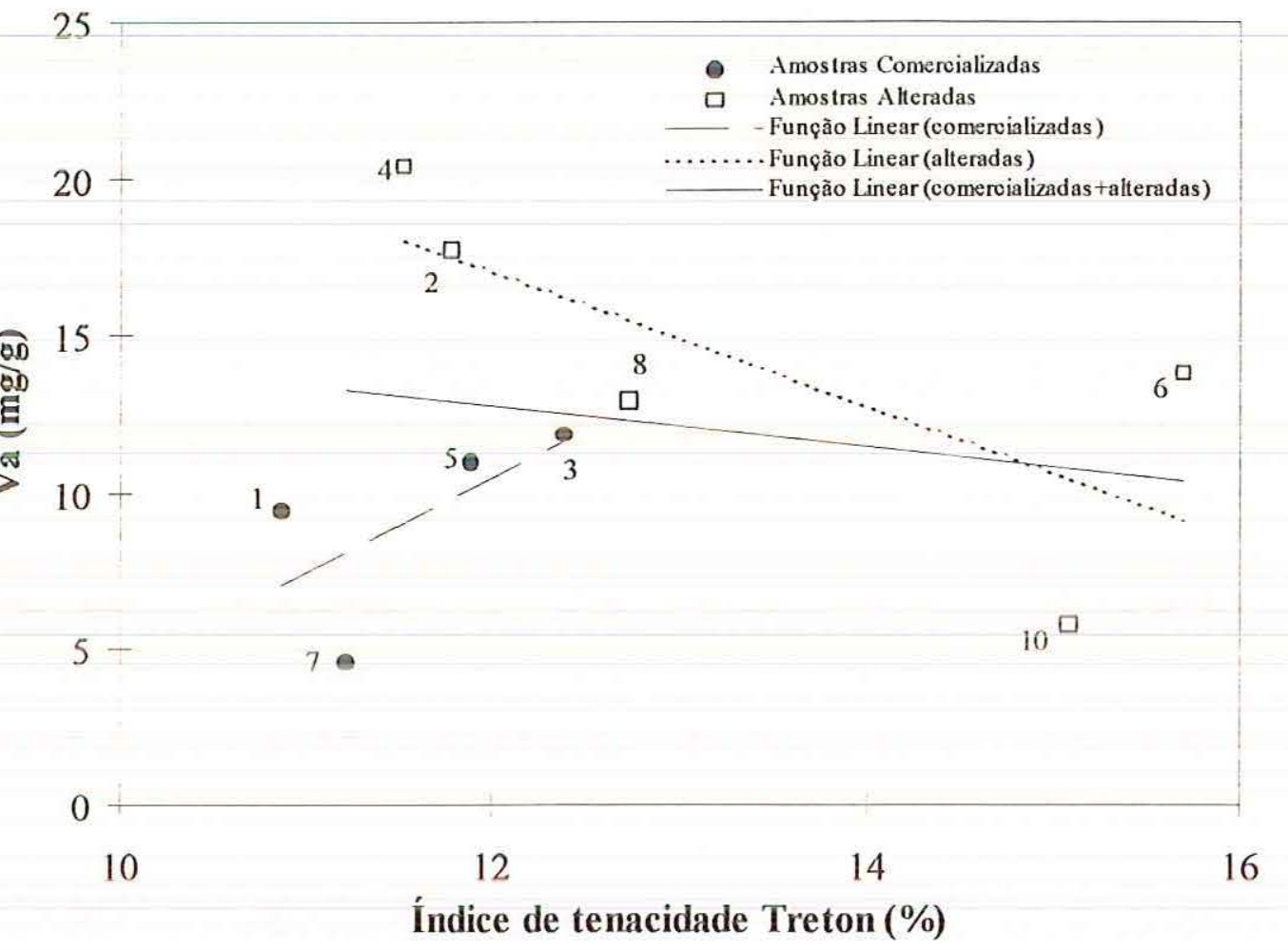

Figura 5.12 - Valores de azul versus valores do índice de tenacidade Treton.

Para amostras "comercializadas" a relação apresenta-se direta com um coeficiente de correlação sofrível, entretanto, mostra uma relação coerente, resultando num aumento do valor de azul (Va) quando aumenta a perda no ensaio de impacto Treton. Já as 
amostras "alteradas" possuem uma relação inversa com um coeficiente de correlação igual a 0,55 .

Observando-se estes resultados pode-se averiguar que ocorre a mesma tendência que houve no caso dos ensaios de desgaste à abrasão, ou seja, para as amostras "comercializadas" os resultados concordam com o previsto (para aumento do Va há aumento da perda), porém, para as amostras "alteradas" ocorre justamente o contrário. Este fato faz com que, considerando-se o conjunto das amostras (“comercializadas" e "alteradas"), a relação obtida seja muito pobre.

A Figura 5.13 mostra a relação entre o ensaio de adsorção de azul de metileno pelo método da mancha e o ensaio de esmagamento.

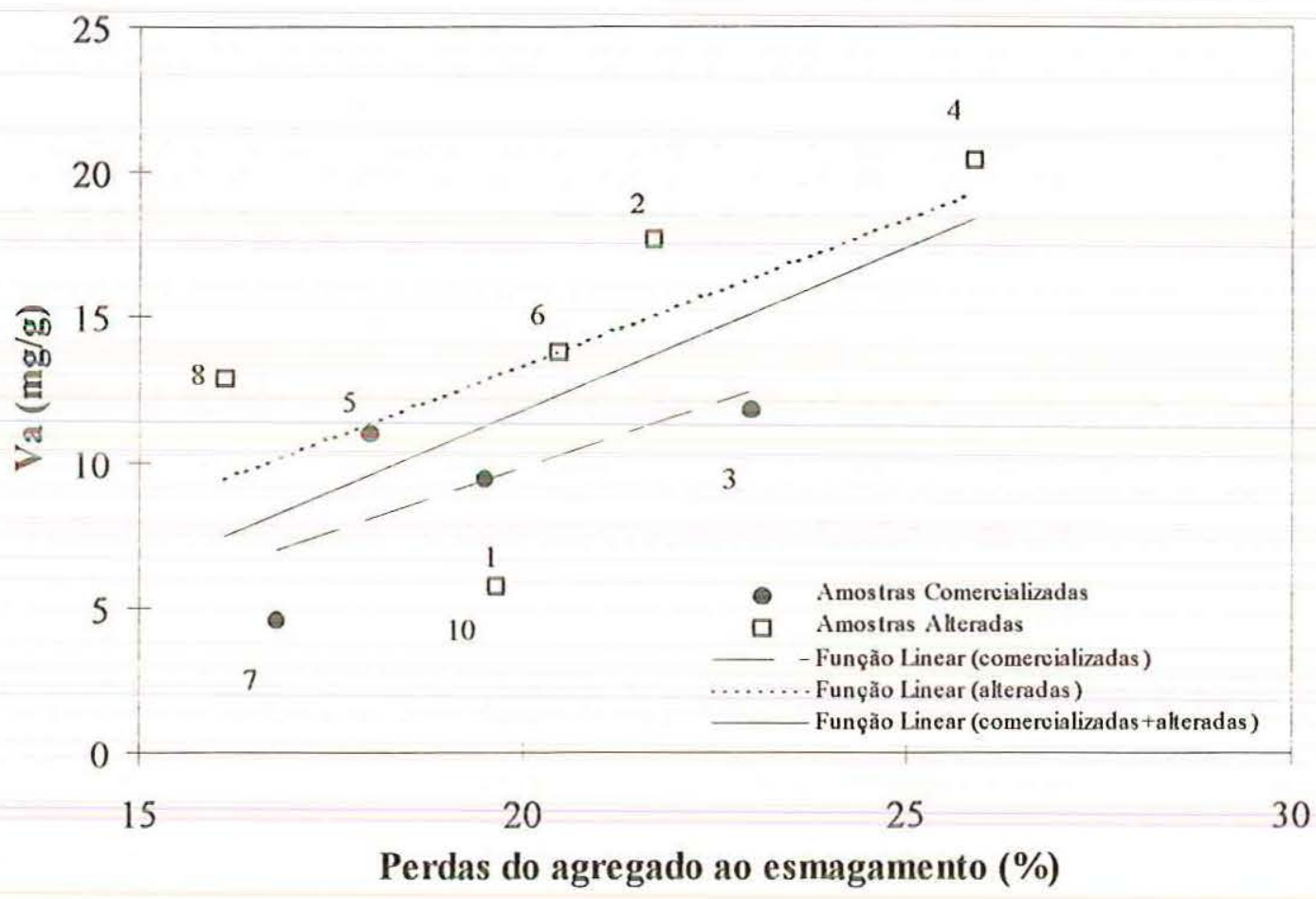

Figura 5.13 - Valores de azul versus valores de perdas do agregado ao esmagamento.

Analisando-se a Figura 5.13, nota-se que as amostras "comercializadas" apresentam relação direta com um coeficiente de correlação igual a 0,53. Já as amostras 
"alteradas" também apresentam relação direta e um coeficiente de correlação sofrível. Para o conjunto das amostras ("comercializadas" + "alteradas") a relação também é direta, com um coeficiente de correlação sofrível.

Observa-se ainda, nesta figura, um comportamento semelhante para as amostras "comercializadas" e "alteradas", pois à medida em que aumenta o valor de azul (Va) a perda no ensaio de esmagamento também aumenta.

A Figura 5.14 apresenta a relação entre os ensaios de adsorção de azul de metileno pelo método da mancha e o de avaliação da resistência mecânica de agregados pelo método dos $10 \%$ de finos.

Neste confronto, as amostras "comercializadas" apresentam uma relação inversa com um coeficiente de correlação igual a 0,72 , observando-se que o valor de azul (Va) decresce à medida que a carga necessária a produção de $10 \%$ de finos cresce. Este resultado era esperado, pois indica que quanto mais "sadia" a amostra, ou seja, com menor presença de microfissuramento e materiais deletérios, maior a carga necessária à produção dos $10 \%$ finos e menor a quantidade de corante adsorvido.

Por outro lado, tanto para as amostras "alteradas", como para o conjunto de amostras, as relações apresentaram-se diretas e com coeficientes de correlação sofriveis

Estes resultados, mais uma vez, são semelhantes aos esperados, ou seja, para as amostras "comercializadas" concordam com o esperado e, para as "alteradas", discordam. 


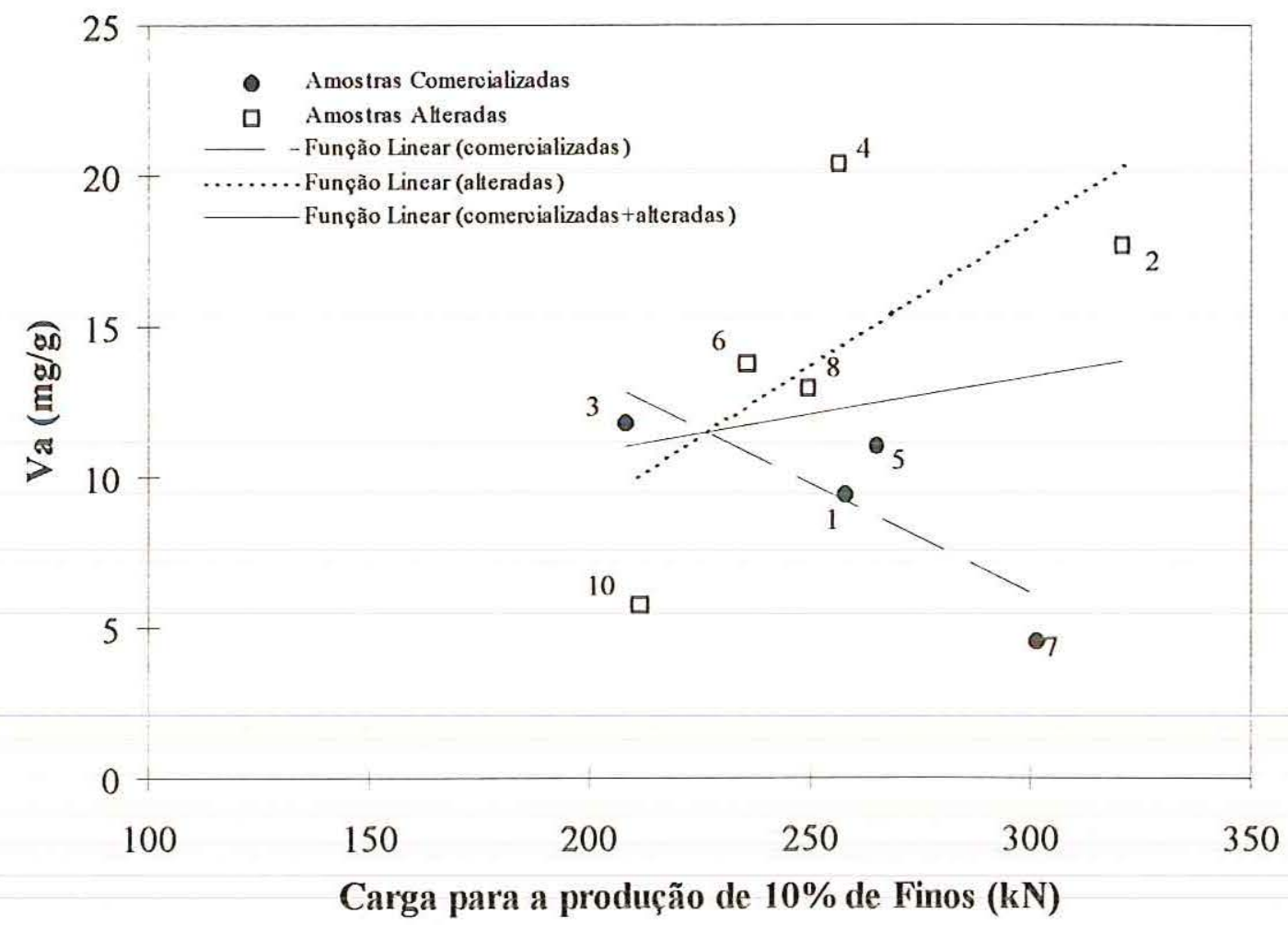

Figura 5.14 - Valores de azul versus valores da carga para a produção de $10 \%$ de finos.

Analisando-se os resultados apresentados nas Figuras 5.11 a 5.14 , percebe-se que, para as amostras "comercializadas", os resultados concordam com o que se poderia esperar, ou seja, para consumos maiores de corantes, têm-se resistência mecânica menor.

Por outro lado, para as amostras "alteradas", os resultados de três dos quatro ensaios aqui testados indicam comportamento não previsível e contrário ao encontrado para as amostras "comercializadas", ou seja, para consumos maiores de corante têm-se resistência mecânica maior também. 


\subsubsection{VALOR DE AZUL (VA) VERSUS RESULTADOS DO ENSAIO DE ALTERAÇÃO}

A Figura 5.15 apresenta a relação entre o ensaio de adsorção de azul de metileno pelo método da mancha e o ensaio de avaliação da durabilidade de agregados pelo emprego de soluções de sulfato de sódio.

Analisando-se a Figura 5.15, nota-se que as amostras "comercializadas" apresentam uma relação direta com coeficiente de correlação igual a 0,57. Já as amostras "alteradas" apresentaram uma relação direta com coeficiente de correlação sofrível. Para todas as amostras a relação é direta e com um cocficiente de correlação igual a 0,53 .

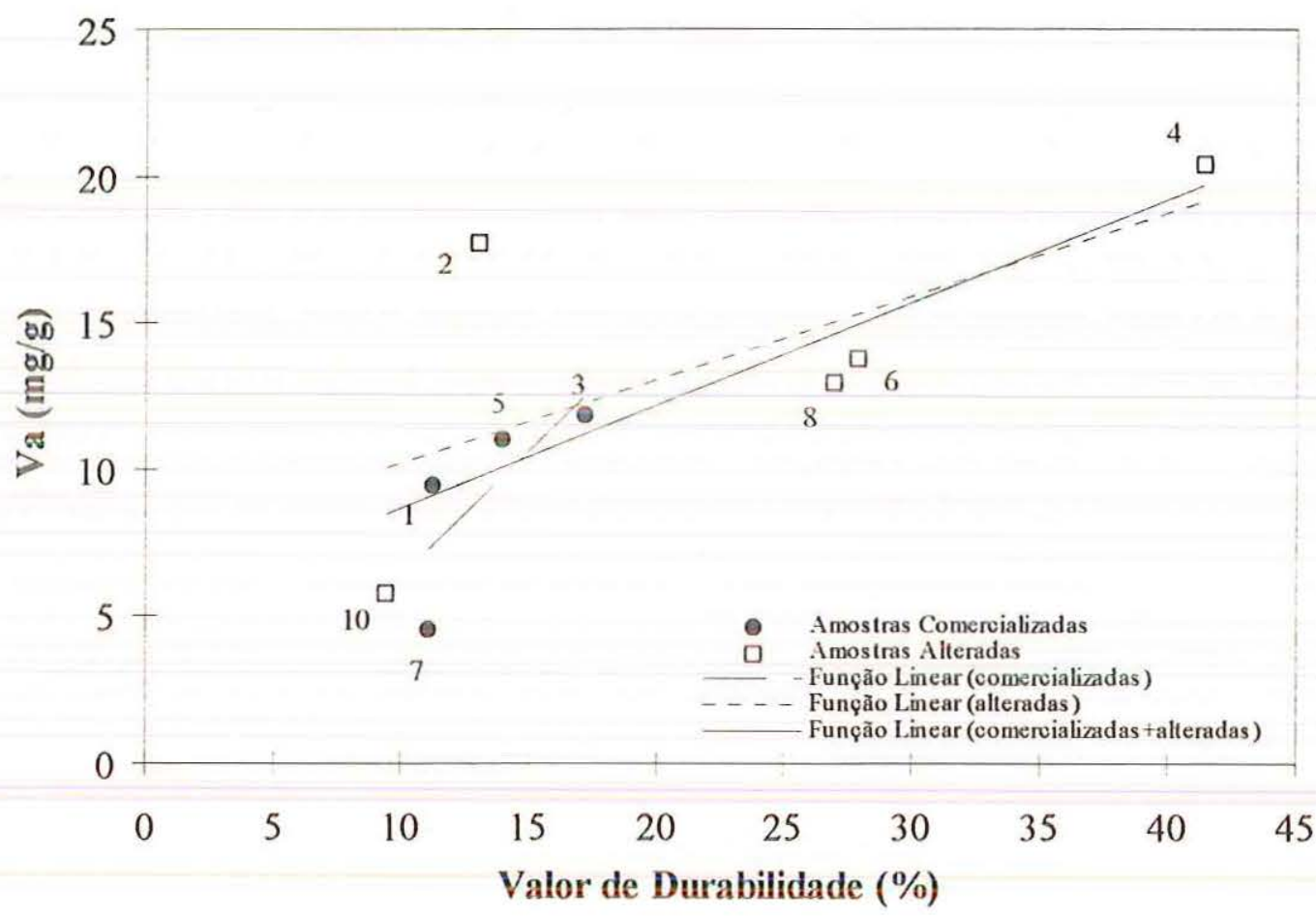

Figura 5.15-Valores de azul versus valores de avaliação da durabilidade de agregados pelo emprego de soluções de sulfato de sódio. 
Nesta figura, observa-se a concordância entre os dois ensaios, porque apresentam tanto para as amostras "comercializadas" como "alteradas" um comportamento previsto, ou seja, o valor de azul (Va) aumenta à medida que o valor de durabilidade ao sulfato de sódio aumenta.

\subsection{DISCUSSÃO DOS RESULTADOS DOS OUTROS ENSAIOS ENTRE SI}

Para fim de análise, os resultados dos ensaios físico-mecânicos e do ensaio de alteração são confrontados entre si. Deseja-se com isto, somente verificar a existência de relações entre os resultados de ensaios distintos.

\subsubsection{DESGASTE DE AGREGADO POR ABRASÃO "LOS ANGELES" VERSUS OUTROS ENSAIOS}

A Figura 5.16 mostra a relação entre o ensaio de desgaste de agregado por abrasão "Los Angeles" e o de determinação do índice de tenacidade de agregado pelo aparelho Treton.

Observando-se esta figura nota-se que as amostras "comercializadas" e "alteradas" apresentam uma relação direta, com coeficiente de correlação sofrível. Já para as nove amostras ("comercializadas" + "alteradas") a relação também é direta, com um coeficiente de correlação de 0,70 .

Analisando-se os resultados apresentados na Figura 5.16 pode-se constatar que, o valor de desgaste de agregado por abrasão "Los Angeles" aumenta juntamente com o valor do índice de tenacidade Treton, sendo que os dois métodos são físico-mecânicos 
e "medem", quantitativamente, o comportamento de uma amostra de rocha ao impacto.

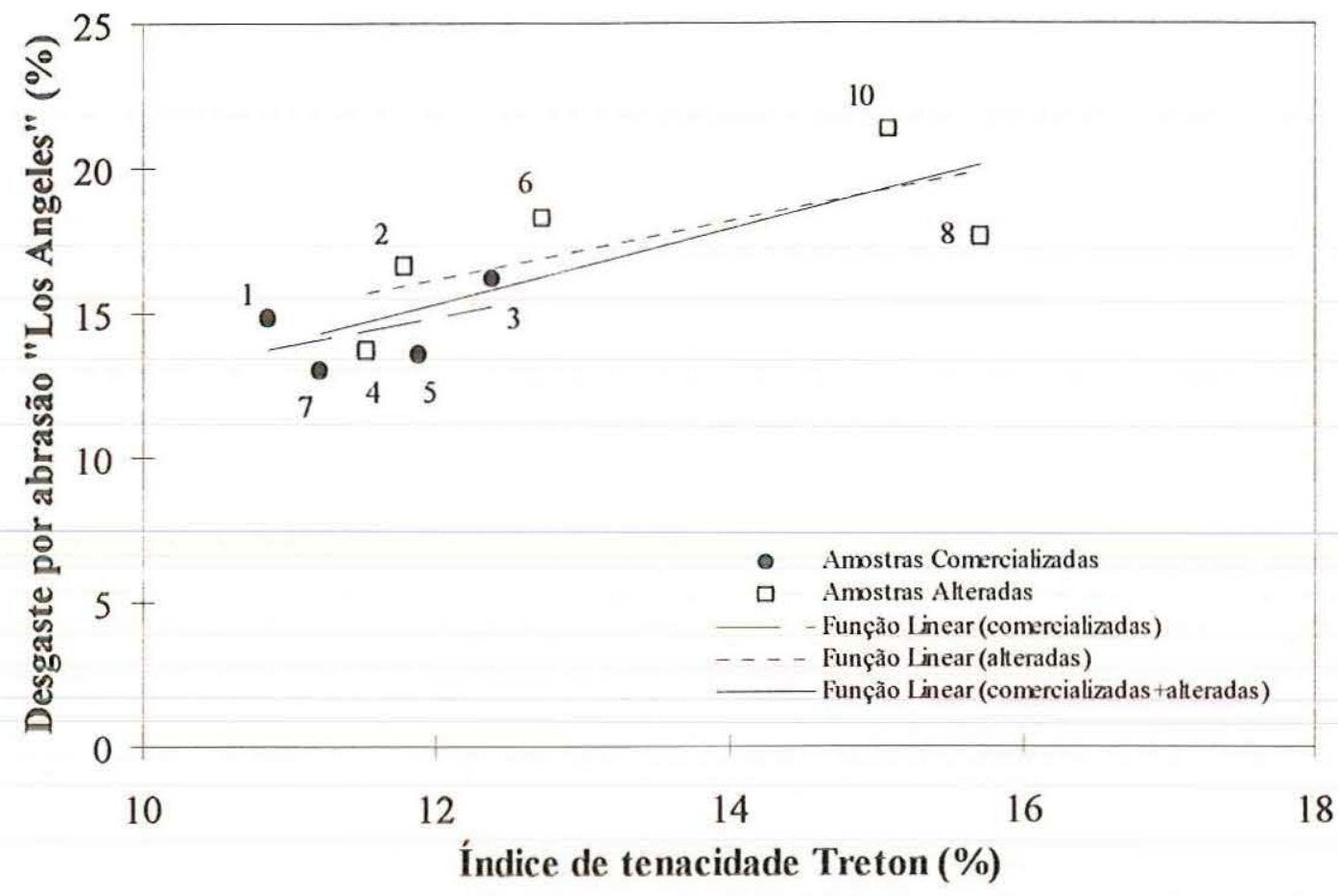

Figura 5.16 - Valores de desgaste de agregado por abrasão "Los Angeles" versus valores do índice de tenacidade Treton.

A Figura 5.17 apresenta a relação entre o ensaio de desgaste de agregado por abrasão "Los Angeles" e o de esmagamento.

Neste confronto, as amostras "comercializadas" apresentam uma relação direta, com um coeficiente de correlação igual a 0,98, observando-se um comportamento diferenciado para as amostras 1, 3, 5 e 7, pois ocorre um aumento do valor de desgaste a abrasão "Los Angeles" à medida que os valores de resistência do agregado ao esmagamento diminuem. 
Já para as amostras "alteradas" a relação é inversa com coeficiente de correlação igual a 0,51. Para todas as amostras, a relação também é inversa e com um coeficiente de correlação sofrível.

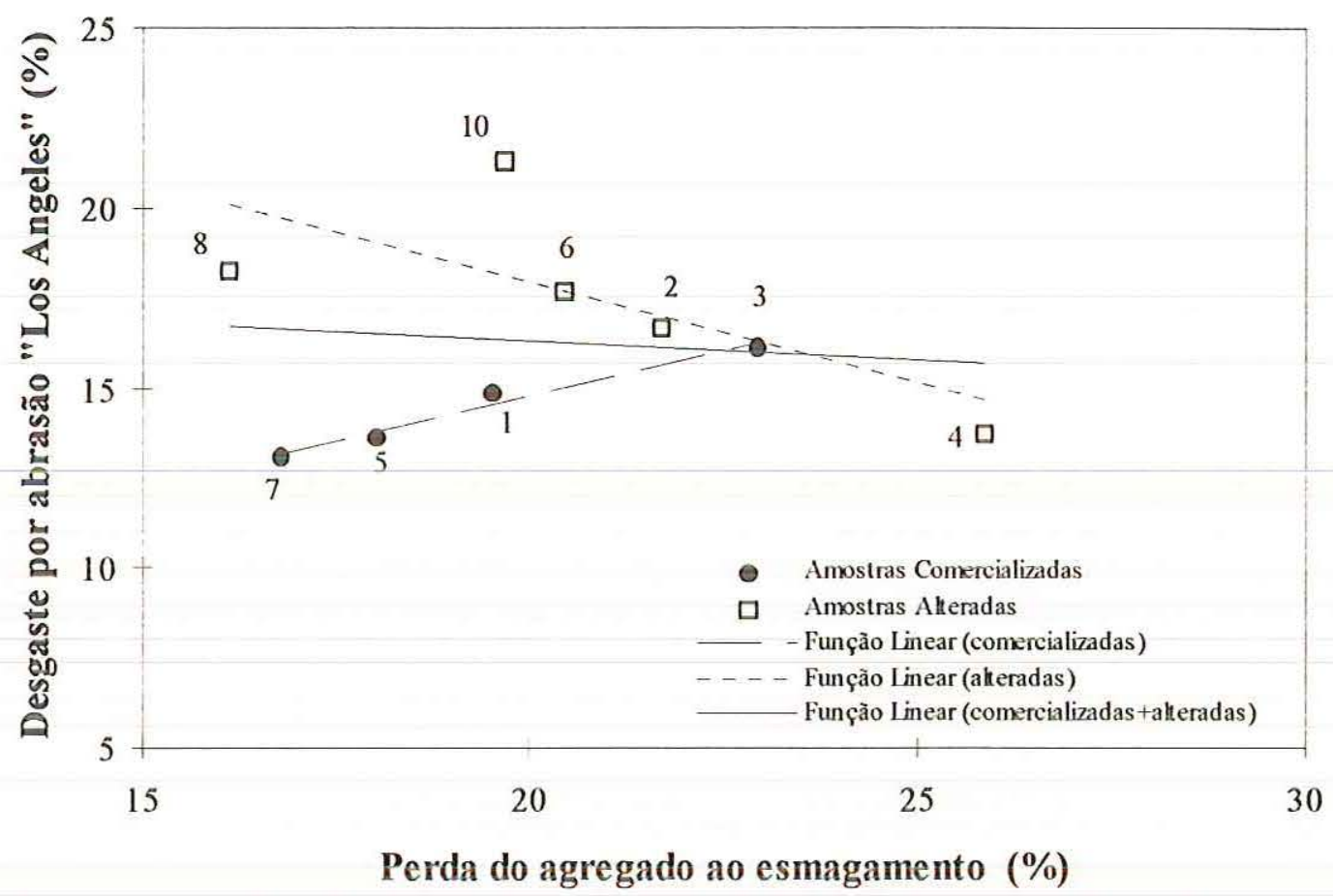

Figura 5.17 - Valores de desgaste de agregado por abrasão "Los Angeles" versus valores do ensaio de esmagamento.

A Figura 5.18 mostra a relação entre o ensaio de desgaste de agregado por abrasão "Los Angeles" e avaliação da resistência mecânica pelo métodos dos 10\% de Finos.

Observando-se esta figura nota-se que para as amostras "comercializadas" a relação é inversa e com coeficiente de correlação igual a 0,91 . Nota-se, novamente, um comportamento distinto para as amostras 1, 3, 5 e 7, pois ocorre uma tendência em diminuir o desgaste a abrasão "Los Angeles" com o aumento do valor da carga necessária para a produção de $10 \%$ de Finos. Os resultados são compatíveis, pois para um agregado que apresenta uma maior resistência mecânica é necessário uma carga de compressão mais elevada para a produção de finos. 
Já para as amostras "alteradas", como para o conjunto das amostras ("comercializadas" + "alteradas"), as relações se apresentaram inversas e com coeficientes de correlação sofríveis.

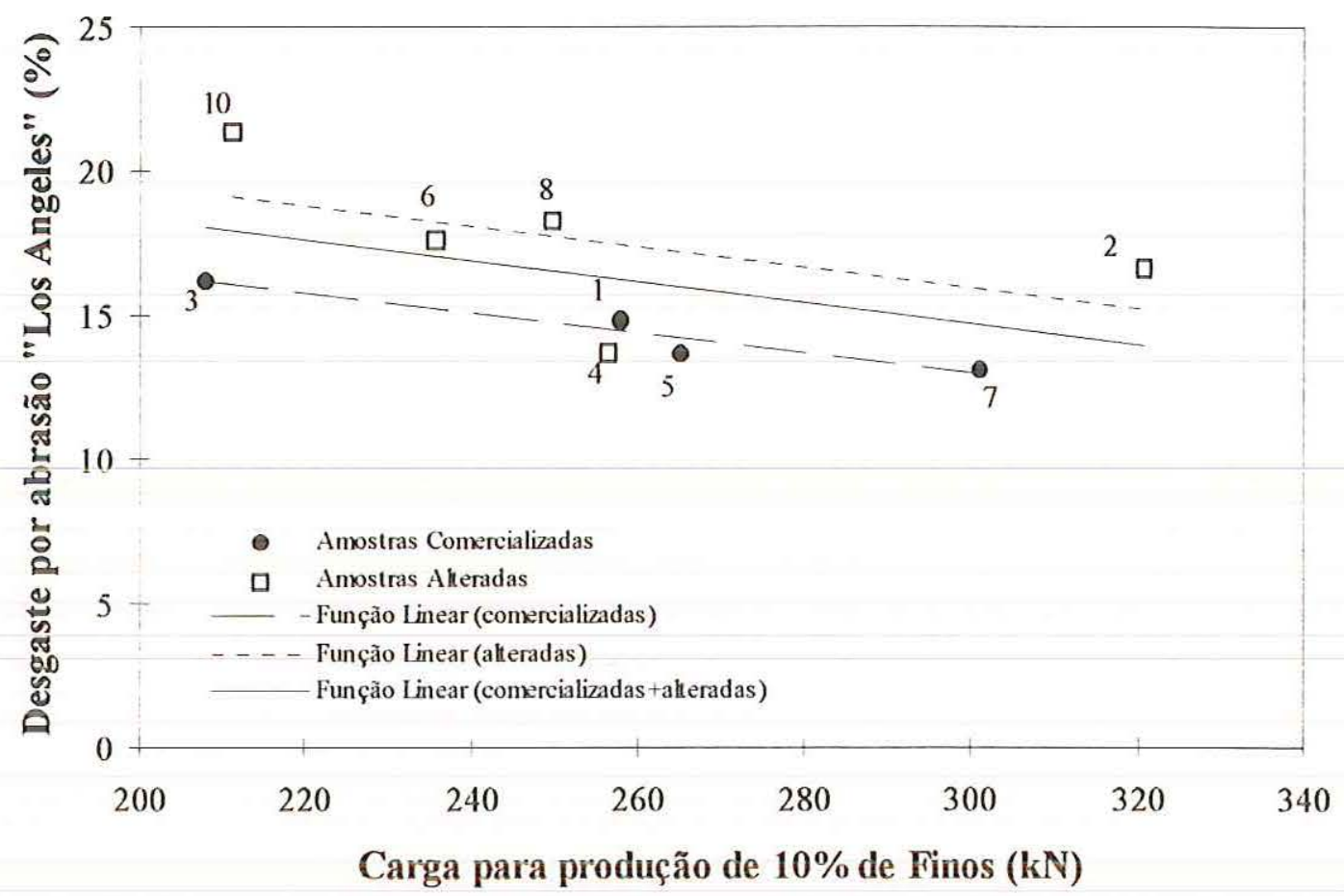

Figura 5.18 - Valores de desgaste de agregado por abrasão "Los Angeles" versus valores de avaliação da resistência mecânica de agregado pelo método dos $10 \%$ de Finos.

A Figura 5.19 apresenta a relação entre o ensaio de desgaste de agregado por abrasão "Los Angeles" e avaliação da durabilidade de agregados pelo emprego de soluções de sulfato de sódio.

Para as amostras "comercializadas", a relação é direta com coeficiente de correlação sofrível. Para as amostras 1, 3,5 e 7, a tendência apresenta-se satisfatória, pois para um aumento do desgaste à abrasão "Los Angeles" (menor resistência mecânica) ocorre um aumento do valor de durabilidade (maior susceptibilidade ao processo de intemperismo fisico). 
Por outro lado, as amostras "alteradas" apresentaram uma relação inversa com coeficiente de correlação igual a 0,60. Neste caso, não se verifica o previsto, ou seja, para uma diminuição do desgaste a abrasão não ocorre uma diminuição do valor de durabilidade.

Observando-se ainda a Figura 5.19 pode-se notar também que não há relação clara entre o desgaste à abrasão e o valor de durabilidade para o conjunto das amostras pois, como já foi dito a relação obtida para as amostras "comercializadas", variam de forma contrária à obtida para as amostras "alteradas", o que torna dificil que tenha uma relação coerente para o conjunto das amostras.

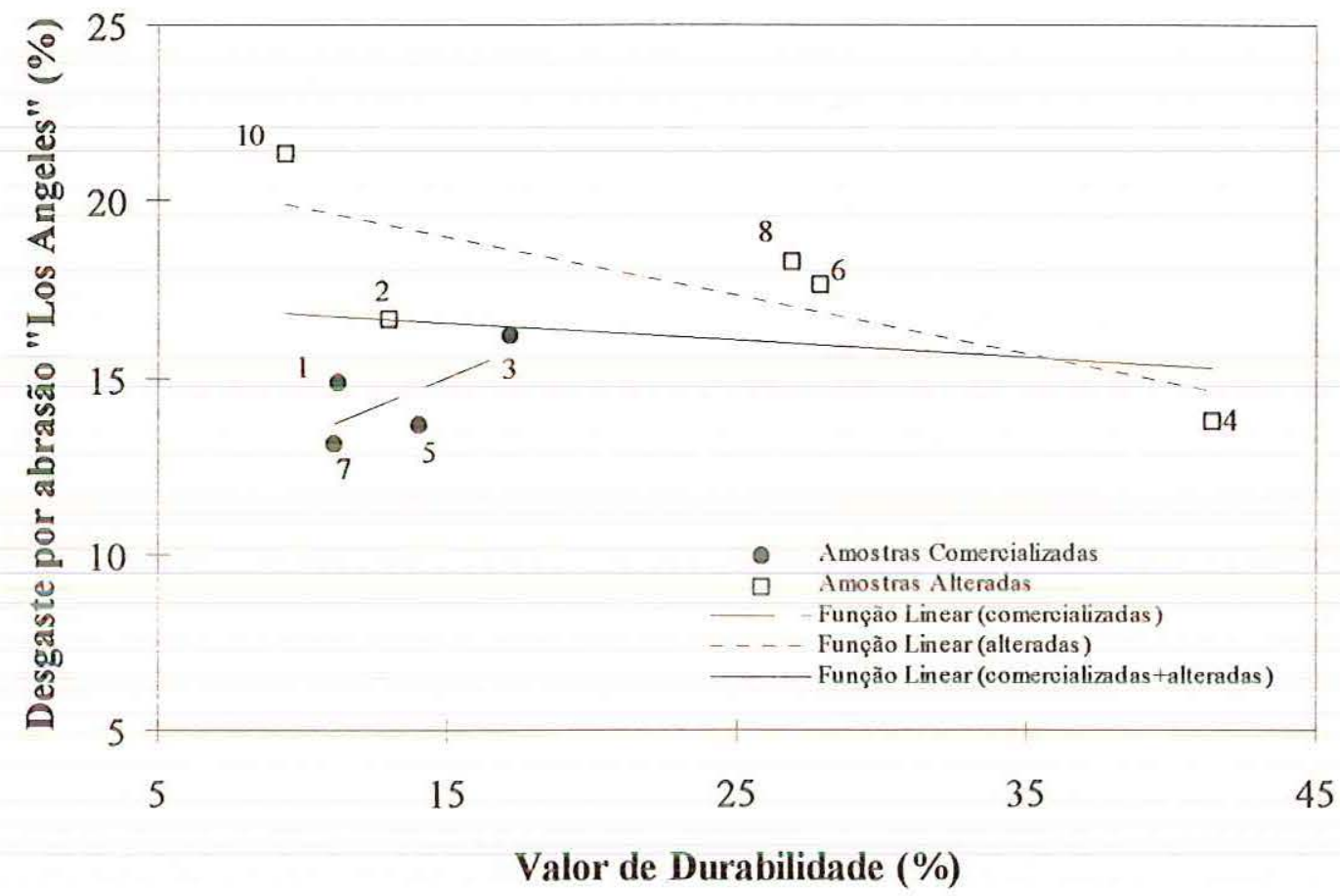

Figura 5.19 - Valores de desgaste de agregado por abrasão "Los Angeles" versus valores de avaliação da durabilidade de agregados pelo emprego de soluções de sulfato de sódio. 


\subsubsection{DETERMINAÇÃO DO ÍNDICE DE TENACIDADE DE AGREGADO PELO APARELHO TRETON VERSUS OUTROS ENSAIOS}

A Figura 5.20 mostra a relação entre o ensaio de determinação do índice de tenacidade de agregado pelo aparelho Treton e de esmagamento.

Para as amostras "comercializadas" a relação é direta com coeficiente de correlação sofrível. Já as amostras "alteradas" a relação é inversa e também um coeficiente de correlação sofrível.

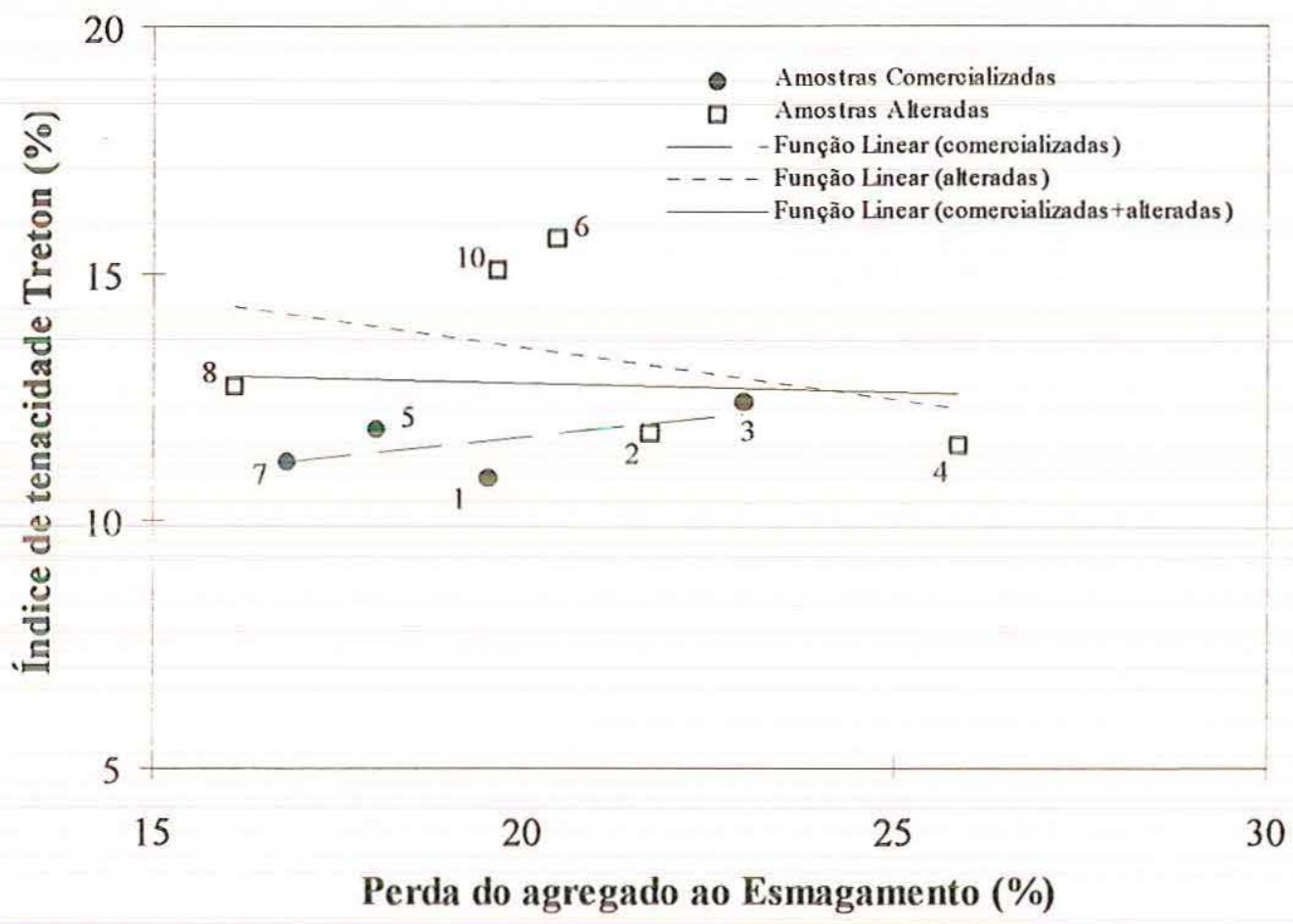

Figura 5.20 - Valores do índice de tenacidade Treton versus valores de perda do agregado ao esmagamento.

Observando-se estes resultados pode-se verificar que para as amostras "comercializadas" os resultados concordam com o previsto (para aumento da perda 
ao esmagamento há aumento da perda por impacto Treton), porém, para as amostras "alteradas" ocorre justamente o contrário. Este fato faz com que, considerando-se o conjunto das amostras ("comercializadas" e "alteradas"), a relação obtida seja fraca.

A Figura 5.21 apresenta a relação entre o ensaio de determinação do índice de tenacidade de agregado pelo aparelho Treton e avaliação da resistência mecânica de agregados pelo método dos $10 \%$ de Finos.

Para as amostras "comercializadas" e "alteradas" a relação é inversa e com coeficiente de correlação sofrível. No geral, para as nove amostras, a relação é inversa com coeficiente de correlação também sofrível.

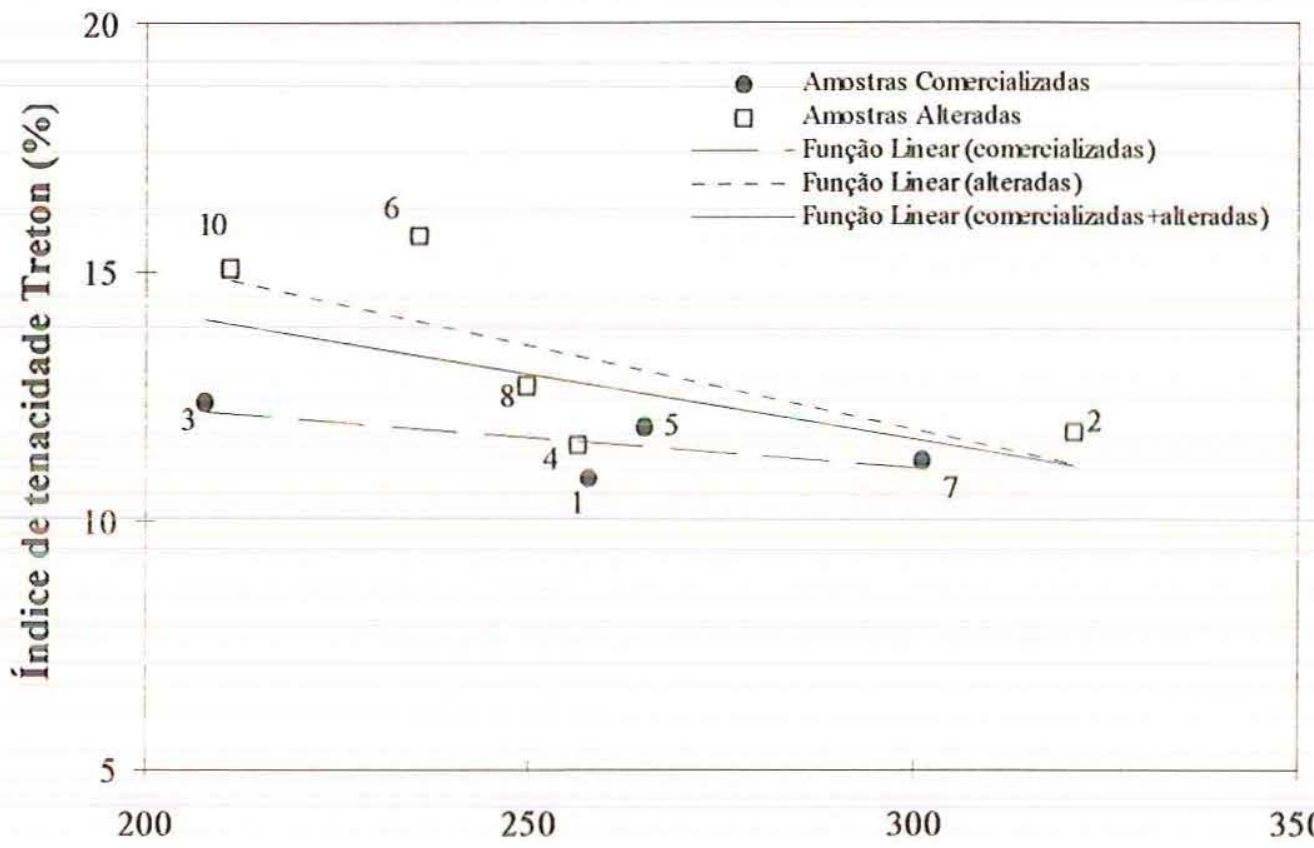

Carga para a produção de $10 \%$ de Finos $(k N)$

Figura 5.21 - Valores do índice de tenacidade Treton versus valores de avaliação da resistência mecânica de agregados pelo método dos 10\% de Finos. 
A Figura 5.22 mostra a relação entre o ensaio de determinação do índice de tenacidade de agregado pelo aparelho Treton e avaliação da durabilidade de agregados pelo emprego de soluções de sulfato de sódio.

Para as amostras "comercializadas" a relação é direta com coeficiente de correlação é igual a 0,93 . Verifica-se que para as amostras $1,3,5$ e 7 ocorre um aumento do valor do índice de tenacidade Treton com o aumento do valor de durabilidade. É interessante notar que são ensaios que avaliam propriedades diferentes da rocha tais como resistência ao impacto e resistência à desagregação por cristalização dos sais.

Para as amostras "alteradas" a relação é inversa com coeficiente de correlação sofrível. Já para o conjunto de amostras, a relação é direta e também com um coeficiente de correlação sofrível.

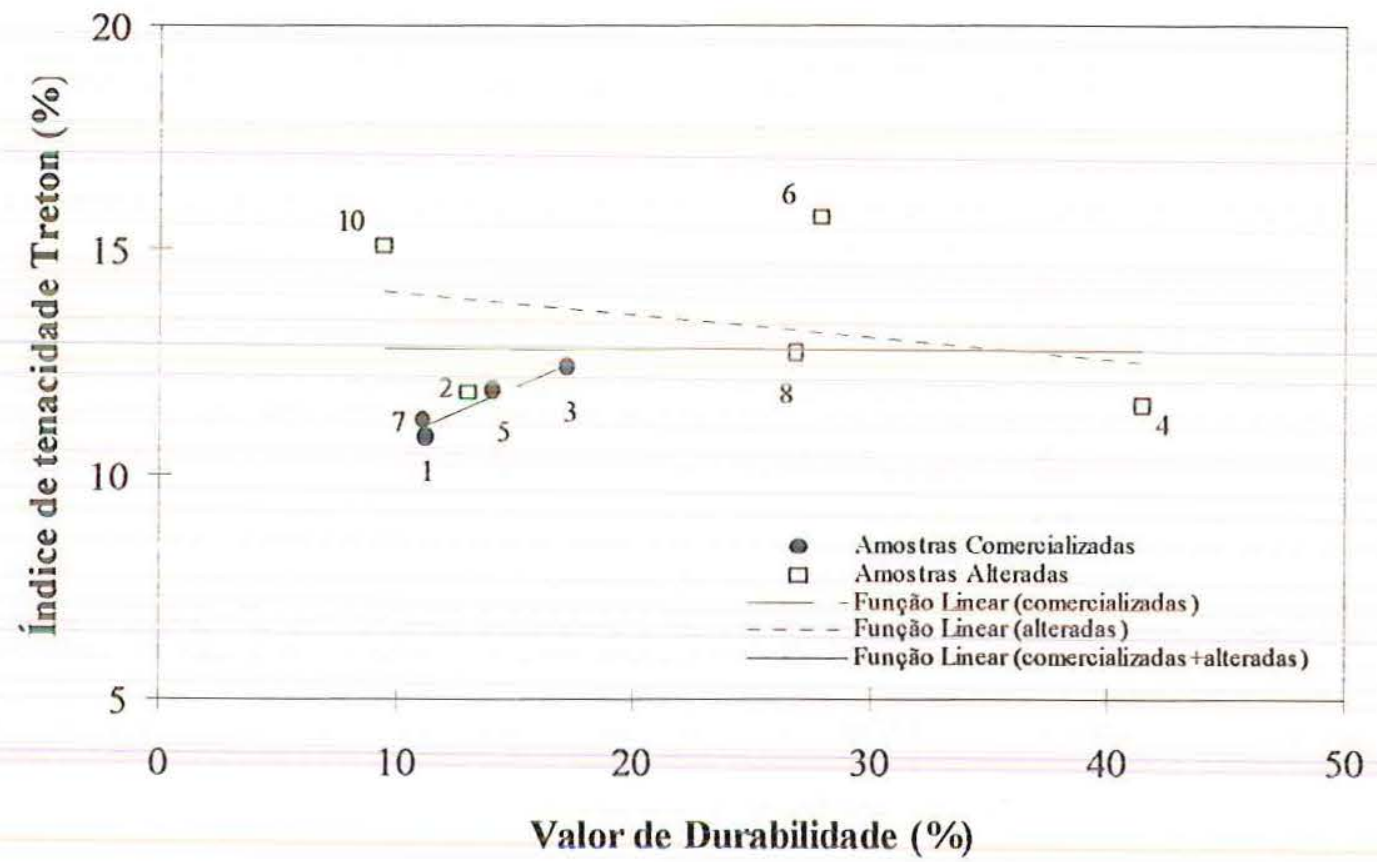

Figura 5.22 - Valores de índice de tenacidade Treton versus valores de avaliação da durabilidade de agregados pelo emprego de soluções de sulfato de sódio. 


\subsubsection{ENSAIO DE ESMAGAMENTO VERSUS OUTROS ENSAIOS}

Segundo MACEDO et alii (1988), existe uma boa correlação entre os ensaios de esmagamento e avaliação da resistência mecânica de agregados pelo método dos $10 \%$ de Finos, principalmente nos agregados mais resistentes. Este fato ocorreu para as amostras "comercializadas" (1, 3, 5 e 7), conforme mostra a Figura 5.23, que apresenta uma relação inversa com um coeficiente de correlação de 0,96.

Já as amostras "alteradas" apresentaram uma relação direta com um coeficiente de correlação sofrível e para o conjunto das amostras obteve-se uma relação inversa com coeficiente de correlação também sofrível.

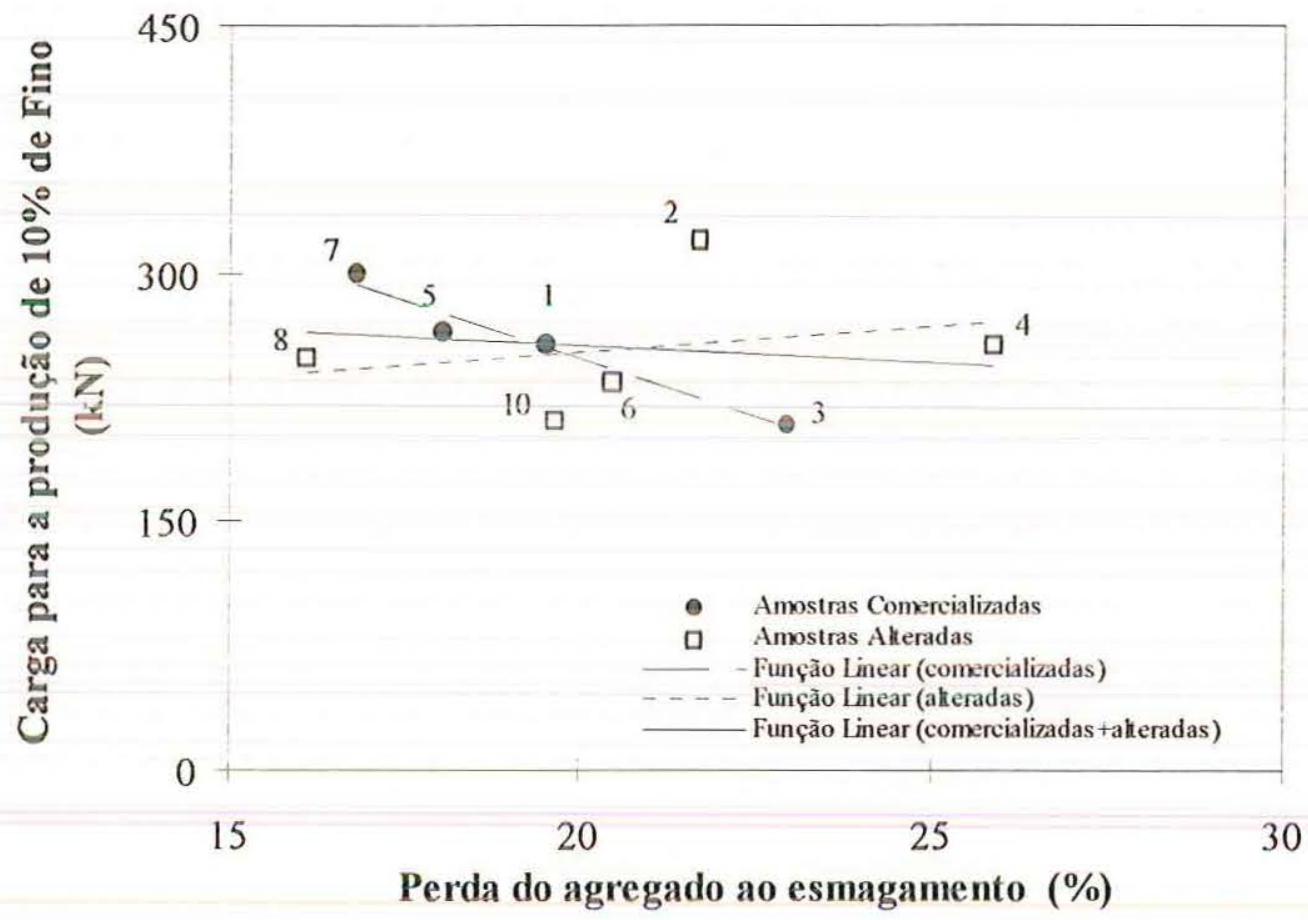

Figura 5.23 - Valores do ensaio de esmagamento versus valores de avaliação da resistência mecânica de agregados pelo método dos 10\% de Finos. 
A Figura 5.24 apresenta a relação entre o ensaio de esmagamento e avaliação da durabilidade de agregados pelo emprego de soluções de sulfato de sódio.

Para as amostras "comercializadas" a relação é direta com coeficiente de correlação igual a 0,64 e para as amostras "alteradas" a relação é direta com coeficiente de correlação sofrível. Já para o conjunto de amostras, a relação é direta com coeficiente de correlação sofrível.

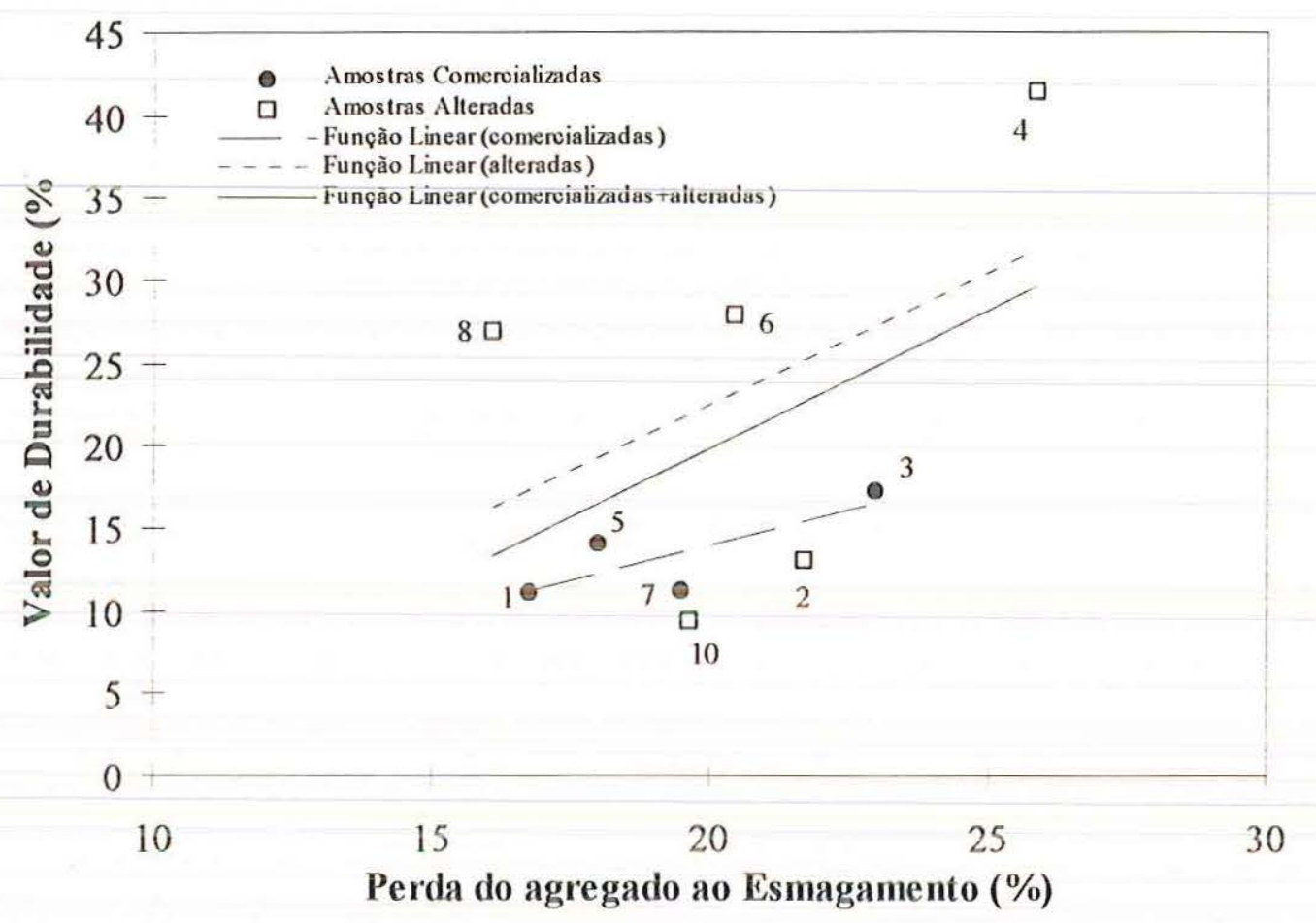

Figura 5.24 - Valores do ensaio de esmagamento versus valores de avaliação da durabilidade de agregados pelo emprego de soluções de sulfato de sódio.

A Figura 5.25 mostra a relação entre o ensaio de avaliação da resistência mecânica de agregados pelo método dos $10 \%$ de finos e do ensaio de avaliação da durabilidade de agregados pelo emprego de soluções de sulfato de sódio. 
Para as amostras "comercializadas" a relação é inversa com coeficiente de correlação igual a 0,74. Verifica-se que para um aumento do valor da carga necessária a produção de $10 \%$ de finos ocorre uma diminuição do valor de durabilidade, sendo uma relação satisfatória, mesmo os ensaios avaliando propriedades diferentes da rocha (agregado). Isto é possivel porque dependendo do grau de alteração de uma rocha há a necessidade de um maior ou menor esforço de compressão para a produção de finos.

Por outro lado, tanto para as amostras "alteradas", como para o conjunto de amostras, as relações se apresentaram inversas e com coeficientes de correlação sofríveis.

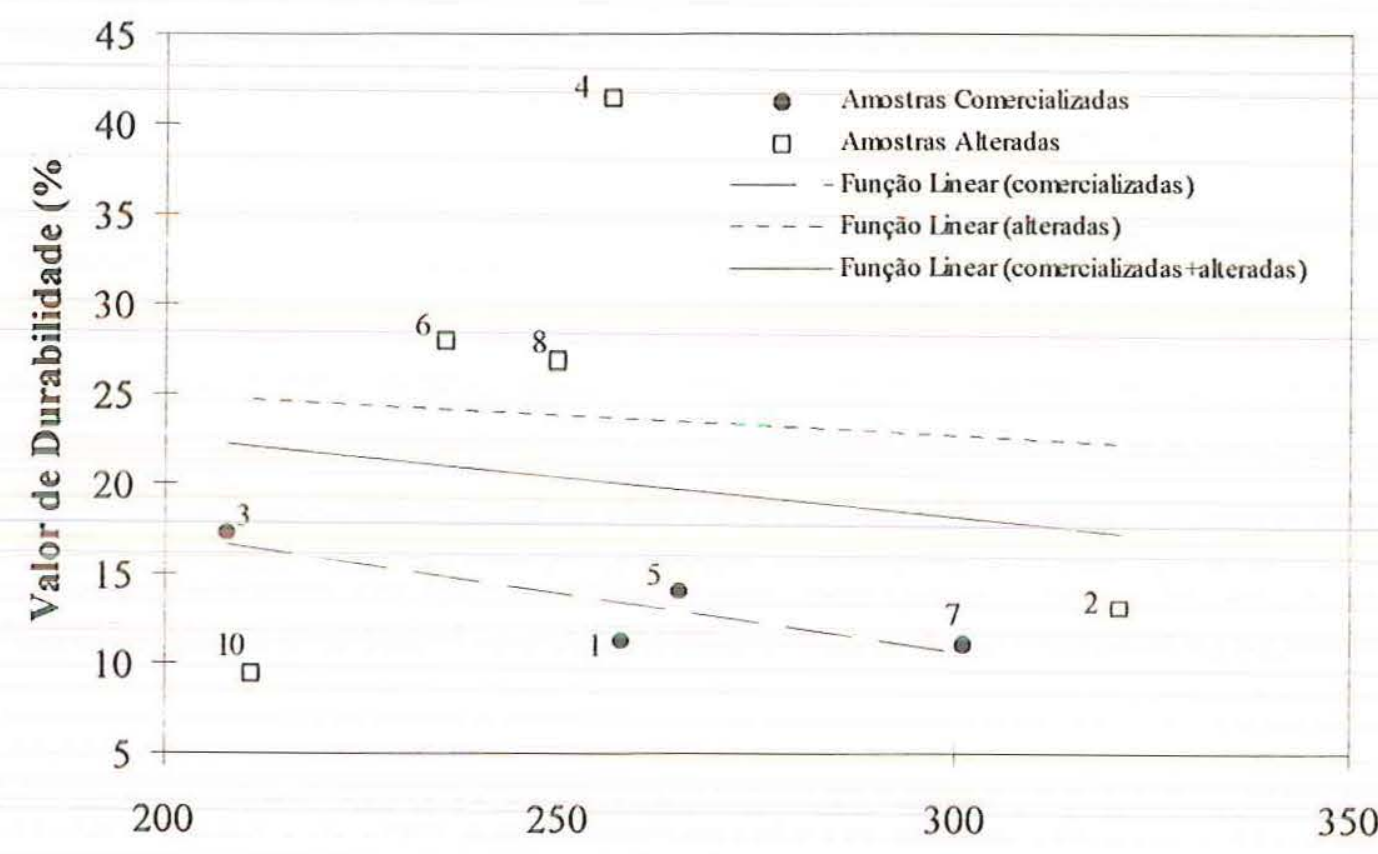

Carga para a produção de $10 \%$ de Finos $(k N)$

Figura 5.25 - Valores da avaliação da resistência mecânica de agregados pelo método dos $10 \%$ de finos versus valores da avaliação da durabilidade de agregados pelo emprego de soluções de sulfato de sódio. 
Analisando-se os resultados apresentados nas Figuras 5.16 a 5.25, observa-se que os confrontos obtidos entre o ensaio de desgaste de agregado por abrasão "Los Angeles" e os ensaios (determinação do índice de tenacidade de agregado pelo aparelho Treton, avaliação da resistência mecânica de agregados pelo método dos $10 \%$ de finos), entre avaliação da durabilidade de agregados pelo emprego de soluções de sulfato de sódio e ensaio de esmagamento e entre determinação do índice de tenacidade de agregado pelo aparelho Treton e avaliação da resistência mecânica de agregados pelo método dos $10 \%$ de finos apresentaram relações coerentes para as amostras "comercializadas" e para as amostras "alteradas", os resultados estão de acordo com o previsto, ou seja, para aumento do desgaste à abrasão, têm-se resistência mecânica menor e também um aumento do valor de durabilidade.

Por outro lado, o confronto entre o ensaio de esmagamento e os ensaios (desgaste de agregado por abrasão "Los Angeles", avaliação da resistência mecânica de agregados pelo método dos $10 \%$ de finos e determinação do índice de tenacidade de agregado pelo aparelho Treton), entre avaliação da durabilidade de agregados pelo emprego de soluções de sulfato de sódio e os ensaios (desgaste de agregado por abrasão "Los Angeles", determinação do índice de tenacidade de agregado pelo aparelho Treton e avaliação da resistência mecânica de agregados pelo método dos $10 \%$ de finos) apresentaram tendências satisfatórias somente para as amostras consideradas "comercializadas", ou seja, para as amostras "alteradas" os resultados indicam comportamento contrário ao encontrado pelas amostras "comercializadas".

\subsection{CONSIDERAÇÕES FINAIS}

Para melhor visualização do comportamento das amostras em relação a cada ensaio, apresenta-se no Quadro 5.10 os resultados hierarquizados dos ensaios analíticos, físico-mecânicos, adesividade, alteração e o de adsorção de azul de metileno pelo 
método da mancha. Observando este quadro nota-se que as amostras apresentam trocas de posições entre elas para cada ensaio.

Analisando-se este mesmo quadro, percebe-se que dos resultados de oito dos doze ensaios aqui avaliados, a amostra 7 apresenta-se na primeira posição, portanto de acordo com o esperado, uma vez que seu aspecto é de rocha de boa qualidade.

Observando-se ainda o Quadro 5.10 pode-se verificar também o comportamento da amostra 10, que teve um resultado insatisfatório nos ensaios de adesividade, isto deve-se possivelmente a presença de "vidro" em sua constituição, o que pode dificultar a adesividade entre os materiais. Por outro lado, pode-se notar também que no ensaio de avaliação da durabilidade de agregados pelo emprego de soluções de sulfato de sódio a amostra 10 apresentou-se em primeira posição.

A partir dos resultados apresentados no Quadro 5.10, formulou-se uma seqüência de alteração decrescente, que permite discriminar o grau de alteração entre as amostras. Para determinação desta seqüência foi observado o maior número de vezes em que cada amostra apresentou em relação aos doze ensaios avaliados e está apresentada a seguir:

$\operatorname{amostra} 7>\operatorname{amostra} 3>\operatorname{amostra} 1>\operatorname{amostra} 2>\operatorname{amostra} 5>\operatorname{amostra} 8>\operatorname{amostra} 6$ $>$ amostra $10>$ amostra 4 
Quadro 5.10 - Posições das amostras em relação a cada ensaio.

\begin{tabular}{|c|c|c|c|c|c|c|c|c|c|c|c|}
\hline $\begin{array}{c}\text { Ordem } \\
\text { Crescente } \\
\text { de } \\
\text { Alteração }\end{array}$ & $\begin{array}{c}\text { Abrasão } \\
\text { "Los } \\
\text { Angeles" }\end{array}$ & $\begin{array}{l}\text { Abrasão } \\
\text { "Los } \\
\text { Angeles" } \\
\text { após } \\
\text { lixiviação } \\
\text { (10 ciclos) }\end{array}$ & $\begin{array}{c}\text { Abrasão } \\
\text { "Los } \\
\text { Angeles" } \\
\text { após } \\
\text { lixiviação } \\
\text { (40 ciclos) }\end{array}$ & $\begin{array}{c}\text { Índice de } \\
\text { tenacidade } \\
\text { Treton }\end{array}$ & Esmagam. & $\begin{array}{c}10 \% \\
\text { de } \\
\text { Finos }\end{array}$ & $\begin{array}{c}\text { Durab. } \\
\text { ao } \\
\text { Sulfato } \\
\text { de } \\
\text { Sódio }\end{array}$ & $\begin{array}{l}\text { Adsorção } \\
\text { de Azul de } \\
\text { Metileno } \\
\text { pelo } \\
\text { método da } \\
\text { mancha }\end{array}$ & $\begin{array}{l}\text { Ades. } \\
\text { graúda }\end{array}$ & $\begin{array}{l}\text { Ades. } \\
\text { miúda }\end{array}$ & $\begin{array}{l}\text { Análise } \\
\text { Macro. }\end{array}$ \\
\hline & 7 & 7 & 7 & 1 & 8 & 7 & 10 & 7 & 7 & 3 & 7 \\
\hline & 5 & 1 & 3 & 7 & 7 & 2 & 7 & 10 & 3 & 5 & 3 \\
\hline & 4 & 3 & 1 & 4 & 5 & 5 & 1 & 1 & 10 & 1 & 1 \\
\hline & 1 & 2 & 5 & 2 & 1 & 1 & 2 & 5 & 1 & 7 & 10 \\
\hline & 3 & 5 & 2 & 5 & 10 & 4 & 5 & 3 & 8 & 6 & 2 \\
\hline & 2 & 10 & 10 & 3 & 6 & 8 & 3 & 8 & 4 & 8 & 5 \\
\hline & 6 & 8 & 8 & 8 & 2 & 6 & 8 & 6 & 5 & 10 & 8 \\
\hline & 8 & 6 & 6 & 10 & 3 & 10 & 6 & 2 & 2 & 2 & 4 \\
\hline$\downarrow$ & 10 & 4 & 4 & 6 & 4 & 3 & 4 & 4 & 6 & 4 & 6 \\
\hline
\end{tabular}




\section{CAPÍTULO 6: CONCLUSÕES}

\subsection{INTRODUÇÃO}

Neste Capítulo são apresentadas as principais conclusões obtidas da avaliação do ensaio de adsorção de azul de metileno pelo método da mancha utilizados para a qualificação de agregados.

Deve-se ressaltar que as conclusões restringem-se ao universo de amostras efetivamente ensaiado. Para facilitar a apresentação, as conclusões foram agrupadas por tipo de ensaio e, quando possível, foram realizados comentários quanto aos resultados obtidos e aqueles que se espera obter.

\subsection{PRINCIPAIS CONCLUSÕES}

\subsubsection{QUANTO AO ENSAIO DE ADSORÇÃO DE AZUL DE METILENO PELO MÉTODO DA MANCHA}

a) o ensaio de adsorção de azul de metileno pelo método da mancha é promissor para a identificação de materiais alterados, indicando a possibilidade da sua utilização na caracterização de agregados basálticos para pavimentação.

b) há grande diferença no consumo de azul de metileno para as rochas "comercializadas" e "alteradas" de mesmo local de origem. As rochas "comercializadas" adsorvem, aproximadamente, metade da quantidade adsorvida

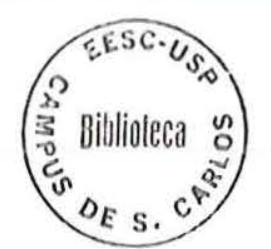


pelas rochas "alteradas", conforme apresentado no Quadro 6.1. Para rochas de origens diferentes, as "comercializadas" também adsorvem menor quantidade de corante em relação às "alteradas", com exceção da amostra 10, de Dois Córregos, que apresentou baixo consumo devido às razões explicitadas no capítulo anterior;

Quadro 6.1 - Relação entre o consumo de azul de metileno entre os pares de rochas de mesmo local de origem.

\begin{tabular}{|c|c|c|c|c|}
\hline Amostras & Procedência & $\begin{array}{c}\text { Denominação } \\
\text { na coleta }\end{array}$ & $\begin{array}{c}\mathrm{Va} \\
(\mathrm{mg} / \mathrm{g})\end{array}$ & $\frac{\mathbf{V a}_{\text {comercializada }}}{V \mathbf{a}_{\text {alterada }}}$ \\
\hline 1 & Santo Antonio & Comercializada & 9,43 & \multirow[t]{2}{*}{0,53} \\
\hline 2 & Santo Antonio & Alterada & 17,71 & \\
\hline 3 & Multipedras & Comercializada & 11,82 & \multirow[t]{2}{*}{0,58} \\
\hline 4 & Multipedras & Alterada & 20,39 & \\
\hline 5 & Ouro Fino & Comercializada & 11,01 & \multirow[t]{2}{*}{0,80} \\
\hline 6 & Ouro Fino & Alterada & 13,78 & \\
\hline 7 & Bandeirantes & Comercializada & 4,57 & \multirow[t]{2}{*}{0,35} \\
\hline 8 & Bandeirantes & Alterada & 12,92 & \\
\hline 10 & Dois Córregos & Alterada & 5,77 & - \\
\hline
\end{tabular}

c) pelo estudo, recomenda-se, como valor tentativo, a adoção de um valor de azul (Va) $\leq 12,5 \mathrm{mg} / \mathrm{g}$ para indicador de rochas basálticas "comercializadas", de acordo com a Figura 5.11 apresentada no Capítulo 5. 


\subsubsection{QUANTO AOS ENSAIOS FÍSICO-MECÂNICOS}

a) os ensaios de desgaste de agregado por abrasão "Los Angeles" mostraram-se incapazes de distinguir os materiais "alterados" dos "comercializados". Os resultados concordam com pesquisa realizada por PARAGUASSU et alii (1987), que indicaram a necessidade de outras técnicas para qualificar agregados para pavimentação;

b) considerando que o ensaio de desgaste de agregado por abrasão "Los Angeles" é largamente utilizado para pré-avaliação da qualidade de agregados, recomenda-se certos cuidados, pois nesta pesquisa todos os agregados ("comercializados" e "alterados") Apresentaram resultados inferiores ao limite especificado em norma (valores $\leq 40 \%$, DER-SP (1991)). A utilização na pavimentação de agregados aceitáveis segundo este ensaio, mas que na verdade não apresentam resistência mecânica satisfatória, podem causar a ruptura do pavimento e/ou sua degradação;

c) o índice de tenacidade Treton não foi capaz de distinguir agregados "comercializados" dos "alterados" e, para todas as amostras, apresentou-se sempre menor que o exigido em norma (valores $\leq 20 \%$, FRAZÃO (1987)), devendo, à semelhança do desgaste de agregado por abrasão "Los Angeles" ser utilizado com cautela;

d) os ensaios de esmagamento e avaliação da resistência mecânica de agregado pelo método dos $10 \%$ de finos são similares quanto a execução do ensaio e aos resultados. Ambos não conseguem diferenciar os materiais "alterados" dos "comercializados". 


\subsubsection{QUANTO AOS ENSAIOS DE ADESIVIDADE}

a) os resultados dos ensaios de adesividade a ligante betuminoso (graúda e miúda), apresentaram-se insatisfatórios para todas as amostras "alteradas";

b) o ensaio de adesividade de agregado miúdo a ligante betuminoso reflete exatamente com as denominações dos agregados das pedreiras, ou seja, exibindo resultados não-aceitáveis para as amostras "alteradas" e aceitáveis para as "comercializadas".

\subsubsection{QUANTO AOS ENSAIOS DE ALTERAÇÃO}

a) o ensaio de alteração por lixiviação contínua com extrator "Soxhlet" conjugado com desgaste de agregado por abrasão "Los Angeles" revelou uma tendência de aumento dos desgastes para as amostras "alteradas" à medida que o número de ciclos cresceu $(0,10$ e 40 ciclos);

b) no ensaio de alteração por lixiviação contínua com extrator "Soxhlet" conjugado com desgaste de agregado por Abrasão "Los Angeles" verificou-se uma tendência, para as amostras "comercializadas", de aumento do desgaste por abrasão com o crescimento de 0 para 10 ciclos e posteriormente uma diminuição do desgaste de 10 para 40 ciclos;

c) o índice de proporção de metais alcalinos e alcalino-terrosos (I) para uma diferença de 30 ciclos para cada amostra somente revelou um enriquecimento temporário dos elementos $\left(\mathrm{Ca}^{+2}, \mathrm{Mg}^{+2}, \mathrm{~K}^{+}\right.$e Na $\left.{ }^{+}\right)$, ou seja, para os números de ciclos utilizados não foi possivel simular alterações nas amostras estudadas;

d) o ensaio de avaliação da durabilidade de agregados pelo emprego de soluções de sulfato de sódio $\left(\mathrm{Na}_{2} \mathrm{SO}_{4}\right)$ mostrou-se eficaz para diferenciar materiais "alterados" 
dos "comercializados". Isto foi verificado pois as amostras "alteradas", com exceção da número 10 , apresentaram valores de durabilidade acima do valor máximo recomendado pela norma (valores $\leq 20 \%$, DER-SP(1991)) e as amostras "comercializadas", valores abaixo.

\subsubsection{OUTRAS CONCLUSÕES}

a) do confronto realizado entre o ensaio de adsorção de azul de metileno pelo método da mancha e os ensaios físico-mecânicos percebe-se que, para as amostras "comercializadas", os resultados concordam com o esperado, ou seja, para consumos maiores de corante, têm-se resistências mecânicas menores.

Por outro lado, para as amostras "alteradas", os resultados da maioria dos ensaios aqui testados indicam comportamento não previsível e contrário ao encontrado para as amostras "comercializadas", ou seja, para consumos maiores de corante têm-se resistência mecânica também maior;

b) observou-se a concordância entre os resultados de adsorção de azul de metileno pelo método da mancha e de alteração. Tanto para as amostras "comercializadas" como para as "alteradas", para valores de azul (Va) maiores têm-se também valores maiores de durabilidade, de acordo com o que se poderia esperar;

c) o confronto realizado entre os outros ensaios (físico-mecânicos e alteração) apresentou relação coerente para as amostras "comercializadas". Os resultados estão de acordo com o previsto, ou seja, por exemplo, para um aumento do desgaste à abrasão, têm-se resistência mecânica menor e também um aumento do valor de durabilidade. No caso das amostras "alteradas", os resultados deste confronto nem sempre foram os esperados, obtendo-se, às vezes, comportamento contrários ao das "comercializadas";

d) de um modo geral, as rochas de alta resistência mecânica inicial são pouco afetadas 
pelos processos de alteração, fato este comprovado pelos ensaios de avaliação da durabilidade de agregados pelo emprego de soluções de sulfato de sódio e alteração por lixiviação contínua com extrator "Soxhlet" conjugado com desgaste de agregado por abrasão "Los Angeles";

e) reconhece-se, por meio das análises individuais de cada ensaio, que existem falhas em alguns dos ensaios usualmente empregados em pavimentação, principalmente quanto à diferenciação entre rochas de comportamentos distintos (“comercializadas" e "alteradas") e quanto aos valores máximos recomendados pelas normas, que muitas vezes não são adequados, como foi mostrado nesta pesquisa.

\subsection{CONSIDERAÇÕES FINAIS}

A partir dos resultados obtidos nesta pesquisa constatou-se que alguns ensaios usualmente utilizados na qualificação de agregados para pavimentação não são capazes de distinguir materiais "comercializados" dos "alterados". Além disto, em certos casos, os valores máximos recomendados nas especificações de materiais são também inadequados para o conjunto de amostras aqui estudadas.

Verificou-se também que o ensaio de adsorção de azul de metileno pelo método da mancha mostrou-se promissor para a caracterização de agregados basálticos, revelando diferenças de consumo de corante significativas para as amostras "comercializadas" e "alteradas".

Recomenda-se, portanto, que sejam realizadas investigações futuras no sentido de avaliar o ensaio de adsorção de azul de metileno quando utilizado para outros tipos de rochas (granitos, gnaisses etc). Sugere-se, também, que os ensaios físico mecânicos (Desgaste de agregado por abrasão "Los Angeles", Determinação do índice de tenacidade de agregados pelo aparelho Treton, Esmagamento e Avaliação da 
resistência mecânica de agregados pelo método dos $10 \%$ de finos) sejam reestudados, ampliando-se o universo de amostras, a fim de se determinar suas adequações e de se estabelecerem limites de aceitação realísticos em função da utilização e dos tipos de agregados analisados. 


\section{REIFERÊNCIAS BIBLIOGRÁFICAS}

BRINDLEY, G. W.; BROWN, G. (1980) - Crystal Structures of Clays Minerals and their X-Ray Identification. Mineralogical Society Monograph $\mathrm{n}^{\circ} 5$ Chapter Five $\mathrm{p}$. 348-357 Inglaterra.

CASANOVA, F.J. (1986) - O Ensaio de Azul de Metileno na Caracterização de Solos Lateriticos: Anais da XXI Reunião Anual de Pavimentação, ABPv. Salvador, BA..

CHEN, T.J.; SANTOS, P. S.; FERREIRA, H. C.; CALIL, S.F.; ZANDONADI, A. R.; CAMPOS, L. V. (1974) - Determinação da Capacidade de Troca de Cátions e da Área Especifica de Algumas Argilas e Caulins Cerâmicos Brasileiros pelo Azul de Metileno e sua Correlação com Algumas Propriedades Tecnológicas. Cerâmica. Vol XX, N 79. São Paulo, SP.

DEGANI, A.; GONCALVES, A. C.; ROSSETTI, J. B. (1979) - Estudo sobre os Ensaios de Adesividade. Departamento de Transportes - STT - USP - São Carlos.

DENNIS, A.; TOURENQ, C.; LAN, T. N. (1980) - Capacite d'Adsorption d'Eau des Sols et des Roches. Bulletin de l' Association Internationale de Géologie de l' Ingenieur. $N^{\circ} 22$. Krefeld. França..

DEPARTAMENTO DE ESTRADAS DE RODAGEM DO ESTADO DE SÃO PAULO (1974) - Métodos de Ensaio. São Paulo.

DEPARTAMENTO DE ESTRADAS DE RODAGEM DO ESTADO DE SÃO PAULO (1991) - Mamual de Normas de Pavimentação. São Paulo. 
DEPARTAMENTO NACIONAL DE ESTRADAS DE RODAGEM (1968) Mamual de Ensaios. Rio de Janeiro.

FABBRI, G. T. P.; SÓRIA, M. H. A. (1991) - Aplicação do Ensaio de Azul de Metileno à Classificação de Solos - Uma Primeira Aproximação. Anais da XXV Reunião Anual de Pavimentação, ABPv. São Paulo, SP.

FABBRI, G. T. P. (1994) - Caracterização da Fração Fina de Solos Tropicais Através da Adsorção de Azul de Metileno. Tese de Doutorado. Escola de Engenharia de São Carlos - USP. São Carlos, SP.

FARJALLAT, J. E. S. (1971) - Critérios de Avaliação de Alterabilidade de Rochas. VII Simpósio de Pesquisas Rodoviárias, IPR. Rio de Janeiro, RJ.

FARJALLAT, J. E. S. (1972) - Desagregabilidade de Rochas e Problemas relativos à sua Aplicabilidade. IV Semana Paulista de Geologia Aplicada, APGA. São Paulo, SP.

FARUQI, F. A.; SUSUMU, O.; WILLIANSON, W. O. (1967) - Chemisorption of Methylene Blue by Kaolinite. Clay Minerals. Vol. 19, № 7.

FERNANDES, J. L. J. (1989) - Efeito da Defloculação no Ensaio de Gramulometria de alguns Solos utilizados em Obras Viárias no Estado de São Paulo. Dissertação. Escola de Engenharia de São Carlos - USP. São Carlos, SP.

FRAZÃO, E. B. (1987) - A Importância das Características Tecnológicas da Pedra para Lastro Ferroviário. Revista Solos e Rochas. № 3, Vol. 10.

FRAZÃO, E. B.; AUGUSTO, F. J. (1994) - Procedimentos para Avaliação da Alterabilidade de Rochas. Anais da XXVIII Reunião Anual de Pavimentação, ABPv. Belo Horizonte, MG. 
GANDOLFI, N.; PARAGUASSU, A. B.; RODRIGUES, J. E.; MARINO, L.; MATtiello, F. (1983) - Ensaios de Laboratórios em Geologia. Publicação 046/91 - USP.p.69 São Carlos, SP.

HANG, P.T.; BRINDLEY, G. W. (1970) - Methylene Blue Adsorption by Clay Minerals - determination of Surface Areas and Cation Exchange Capacities (Clay-Organic Studies XVIII). Clays and Clay Minerals. Vol.18 Inglaterra.

HIGGS, N. B. (1988) - Methylene Blue Adsorption as a Rapid and Economical Method of Detecting Smectite. Geotechinical Testing Journal, ASTM. N ${ }^{\circ}$, Vol.11 USA.

HUET, M. (1989) - Incidence de la Variation de la Valeur de Bleu sur Certaines Caractéistiques des Fines et des Enrobés. Bulletin de Liaison des Laboratoires des Ponts et Chaussées. $N^{\circ} 161$. França.

INSTITUTO DE PESQUISAS TECNOLÓGICAS (1980) - Caracteristicas Tecnológicas das Rochas Utilizadas como Material Natural de Construção Civil no Eslado de São Paulo. Relatório $N^{\circ} 14.710$.

INSTITUTO DE PESQUISAS TECNOLÓGICAS (1981) - Mapa Geológico do Estado de São Paulo - escala 1:500.000. Série Monografias (6), Vol. I.

JONES, F. O. (1964) - New Fast, Accurate Test Measures Bentonite in Drilling Mud. Oil Gas Journal. Vol. 62, p. 76-78.

KIPLING, J. J.; WILSON, R. B. (1960) - Adsorption of Methylene Blue in the Determination of Surface Areas. Journal of Applied Chemistry. № 10. 
LAN, T. N. (1977) - Un Nouvel Essai d'Identification des Sols - L' Essai au Bleu de Methylene. Bulletin de Liaison des Laboratoires des Ponts et Chaussées. № 88 . França.

LAN, T. N. (1980) - L'Essai au Bleu de Méthylène - Un Progrès dans la Mesure et le Contrôle de la Propreté des Gramulats. Bulletin de Liaison des Laboratoires des Ponts et Chaussées. $N^{\circ} 107$. França.

LAN, T. N. (1981) - Utilisation de l'Essai au Bleu de Methylene en Terrassement Routier: Bulletin de Liaison des Laboratoires des Ponts et Chaussées. $\mathrm{N}^{\circ} 111$. França.

LAUTRIN, D. (1987) - Une Procédure Rapide d'Identification des Argiles. Bulletin de Liaison des Laboratoires des Ponts et Chaussées. N 152 . França.

MACEDO, P. H. S.; CORREA, W. G.; ABREU, J. A. A. K. P. (1988) Caracterização Tecnológica dos Agregados destinados a Pavimentação com Concreto de Cimento Portland. Anais da XXIII Reunião Anual de Pavimentação, ABPv. Florianópolis, SC.

MITCHELL, G.; POOLE, P.; SEGROVE, H. D. (1955) - Adsorption of Methylene Bleu by High-Silica Sands. Nature. No 26. França.

NEVINS, M. J.; WEINTRITT, D.J. (1967) - Determination of Cation Exchange Capacity by Methylene Bleu Adsorption. Ceramic Bulletin. N 6, Vol. 46.

NOGAMI, J. S.; VILLIBOR, D. F. (1981) - Uma Nova Classificação de Solos para Finalidades Rodoviárias. Simpósio Brasileiro de Solos Tropicais em Engenharia. Rio de Janeiro, RJ. 
PARAGUASSU, A. B.; GANDOLFI, N.; FABBRI, G. T. P. (1987) - Influência das Partículas Finas no Ensaio de Abrasão Los Angeles. Anais do Congresso Brasileiro de Geologia de Engenharia. ABGE. Vol. 2, p. 367-370 São Paulo, SP.

PARKER, A. (1970) - An Index of Weathering for Silicate Rocks. Geological Magazine. Vol. 107, p. 501-504.

PEJON, O. J. (1992) - Mapeamento Geotécnico Regional da Folha de Piracicaba SP (escala 1:1000000): Estudo de Aspectos Metodológicos de Caracterização e de Apresentação de Atributos. Tese (Doutorado). Escola de Engenharia de São Carlos da USP.

PHELPS, G. W.; HARRIS, D. L. (1968) - Specific Surface and Dry Strenght Methylene Bleu Adsorption. Ceramic Bulletin. № 12, Vol. 47.

PICCOLO, J. R.; ADISSY, M. A. (1970) - Adesividade de Agregado a Ligante Betuminoso. Anais do Congresso da Segunda Semana Paulista de Geologia Aplicada. APGA. Vol. 2, p. 587-599 São Paulo, SP.

SCHNEIDER, A. M.; PIRES DA ROCHA, F. X. (1968) - Emprego de Basaltos em Pavimentação Rodoviária. IPR, N 433, p.43 Rio de Janeiro.

SHREVE, R. N.; BRINK, J. A. (1980) - Indústrias de Processos Quimicos. Guanabara Dois. Cap. 39, p. 638-675 Rio de Janeiro.

TOURENQ, C.; LAN, T. N. (1989) - Mise en Évidence des Argiles par l'Essai au Bleu de Methylene - Application aux Sols, Roches et Gramulats. Bulletin de Liaison des Laboratoires des Ponts et Chaussées. № 159. França. 
YOSHIDA, R. . (1972) - Contribuição ao Conhecimento de Caracteristícas Tecnológicas de Materiais. Tese de Doutorado. Instituto de Geociências, Universidade de São Paulo, SP. 


\section{ANEXO II}

FOTOS DOS LOCAIS DE COLETA DAS AMOSTRAS 


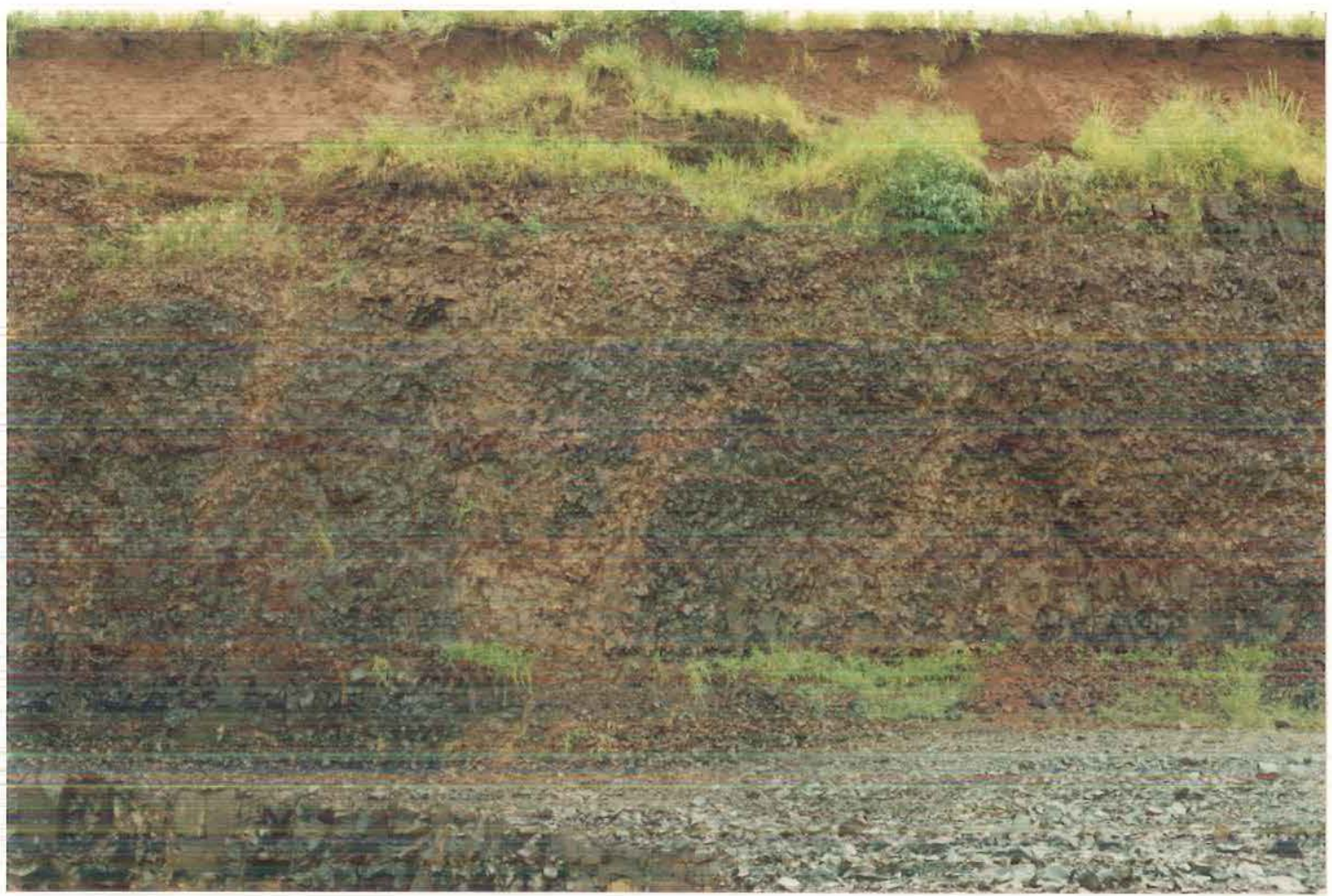

Figura I.1 - Detalhe da amostra "comercializada" pertencente a Pedreira Santo Antonio.

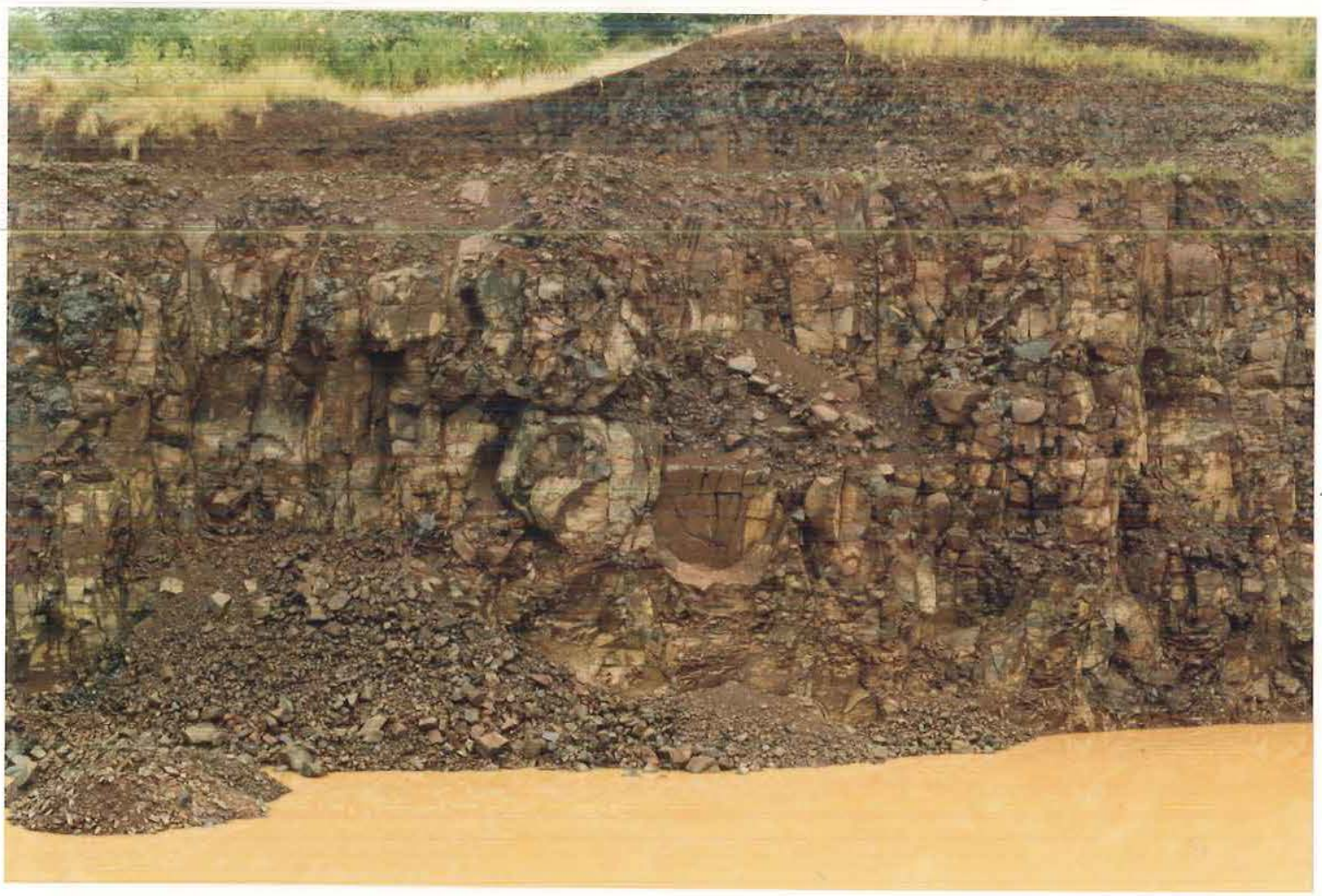

Figura I.2 - Detalhe da amostra "alterada" pertencente a Pedreira Santo Antonio. 


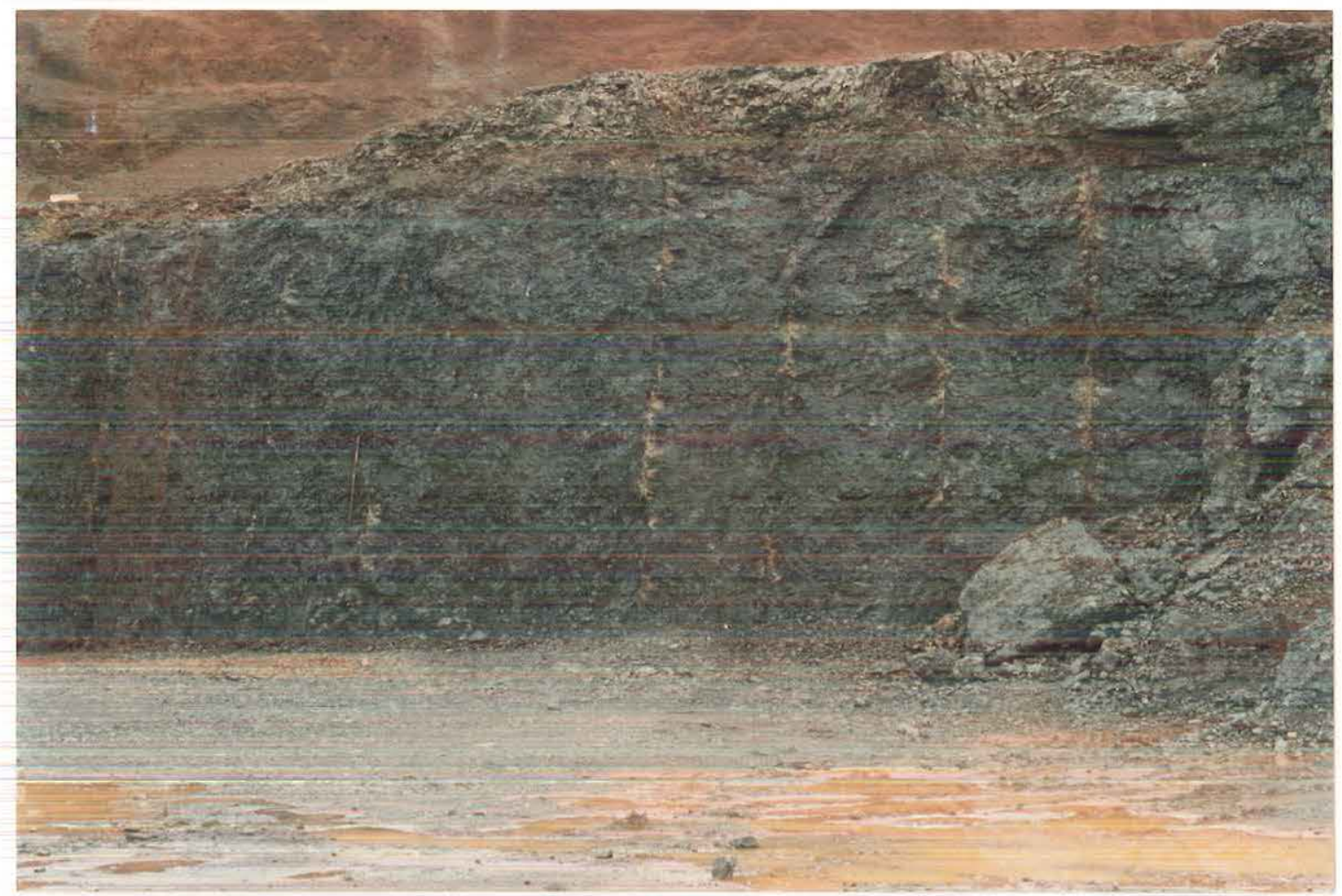

Figura I.3 - Detalhe da amostra "comercializada" pertencente a Pedreira Multipedras.

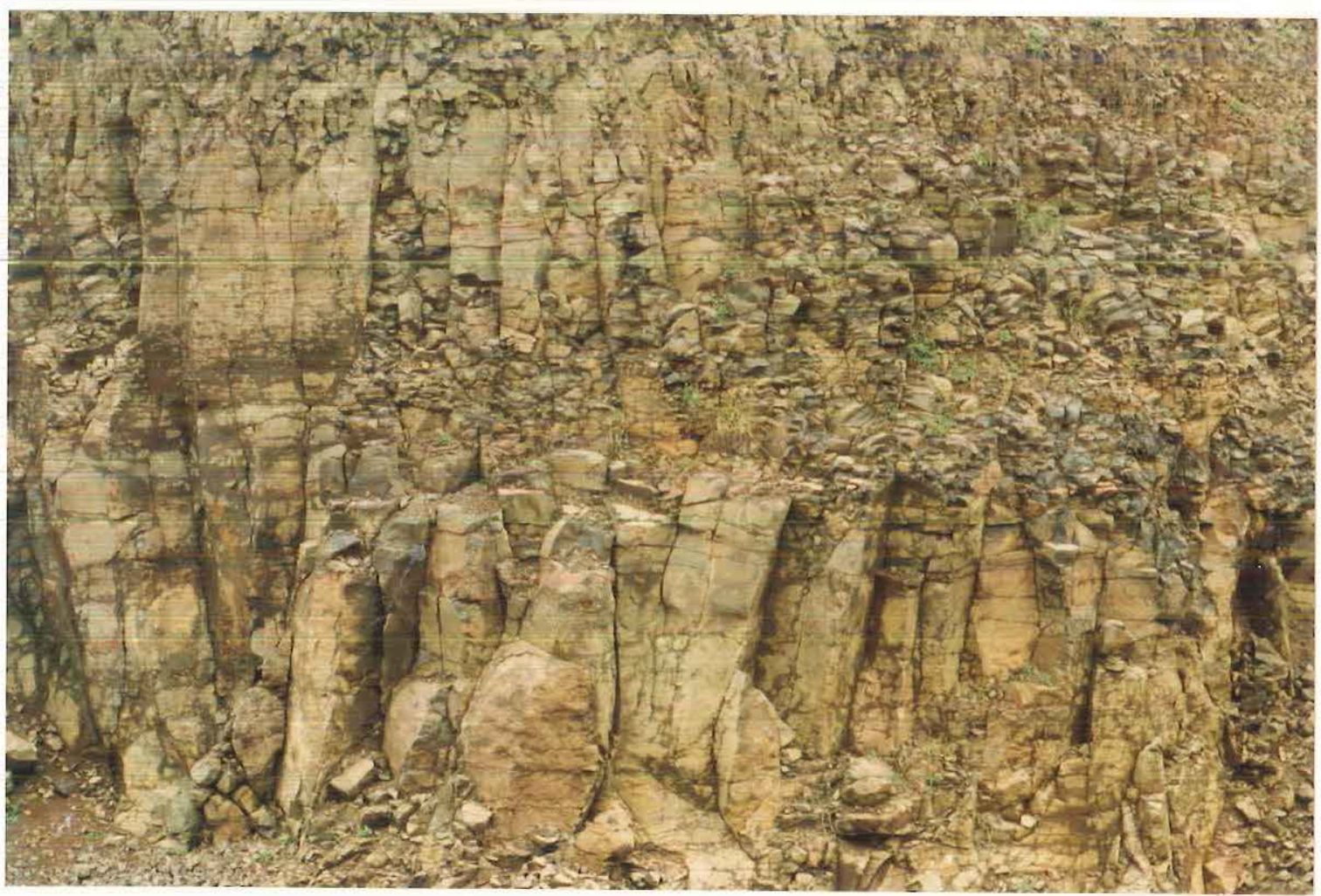

Figura I.4 - Detalhe da amostra "alterada" pertencente a Pedreira Multipedras. 


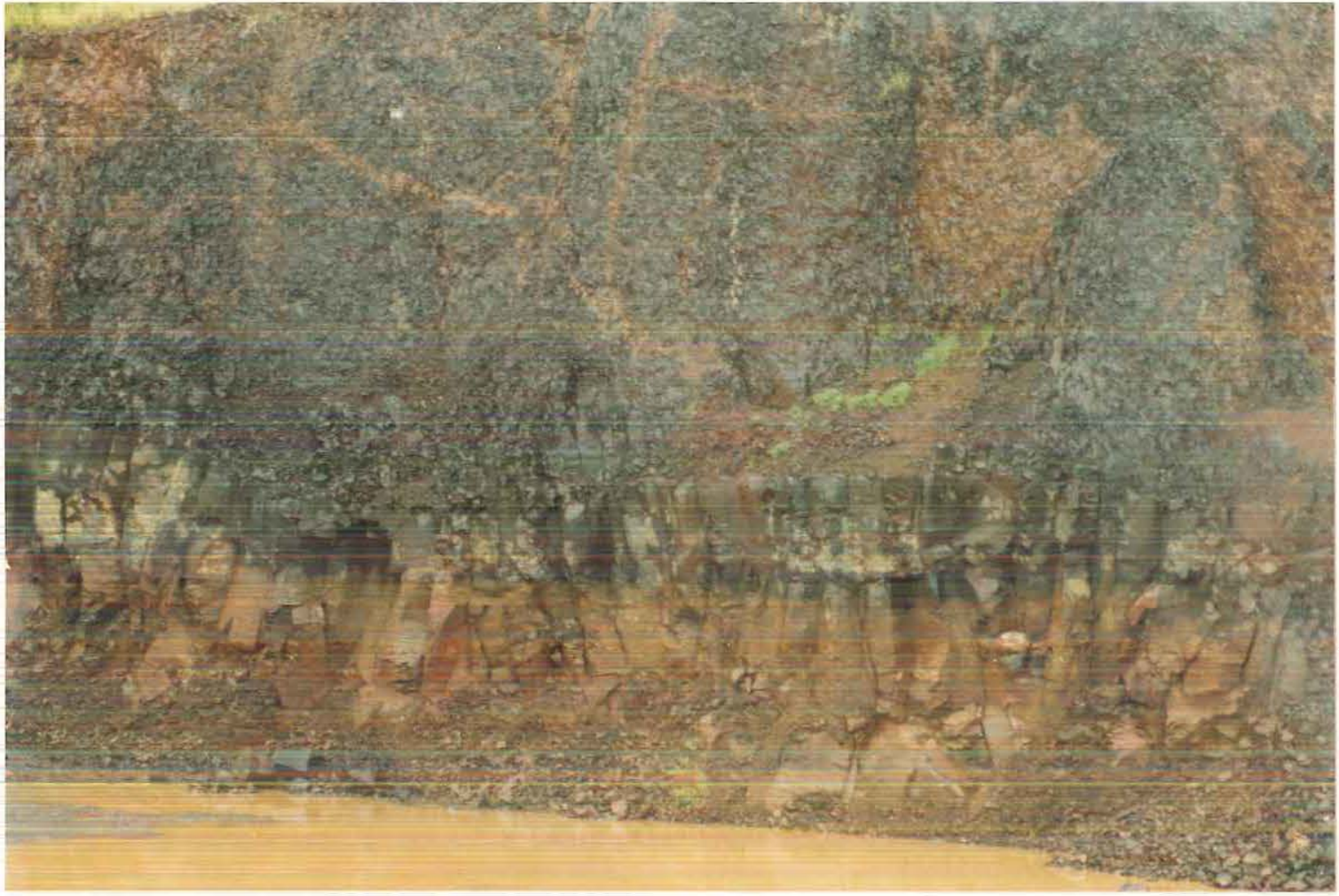

Figura I.5 - Detalhe da amostra "comercializada" pertencente a Pedreira Ouro Fino.

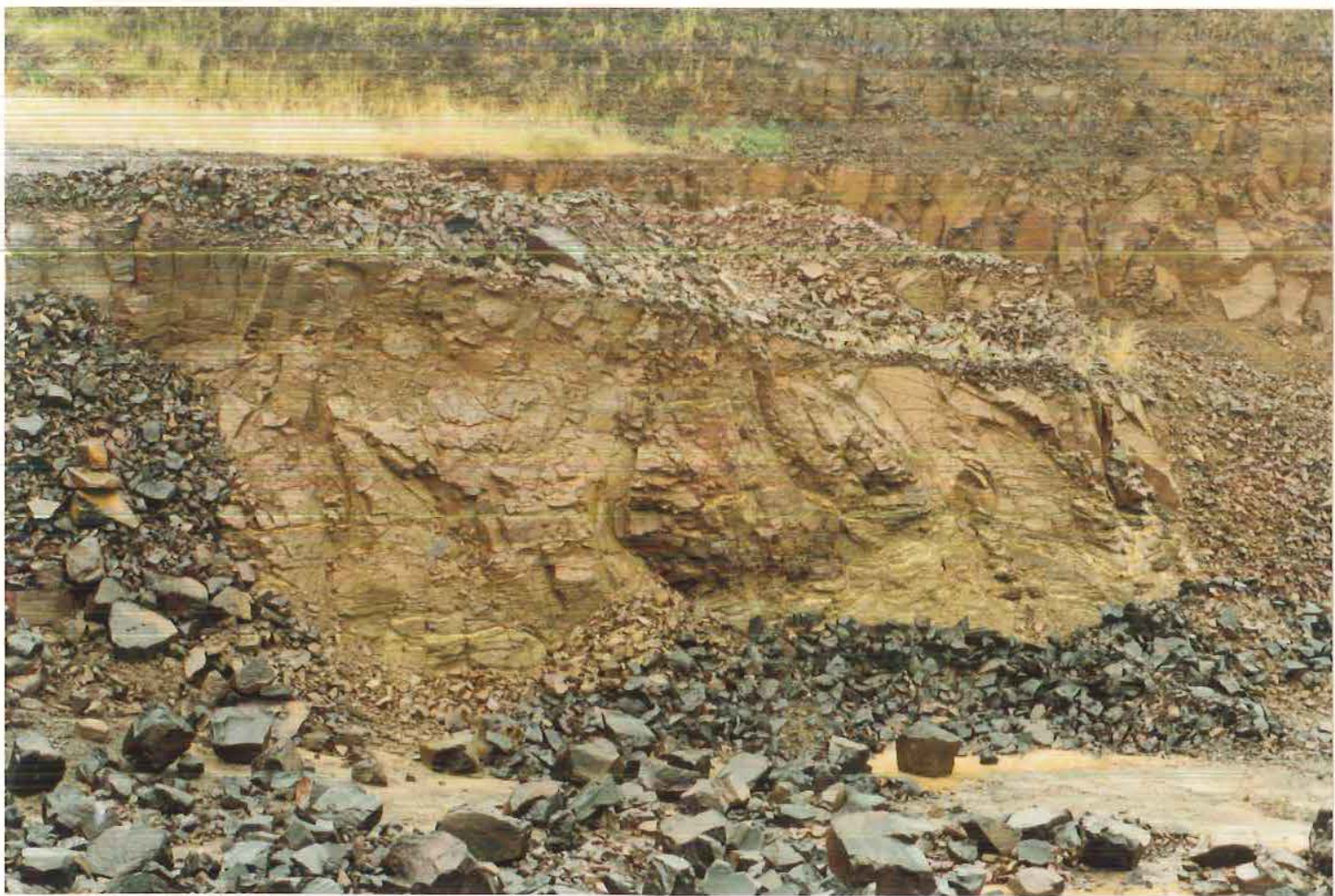

Figura I.6 - Detalhe da amostra "alterada" pertencente a Pedreira Ouro Fino. 


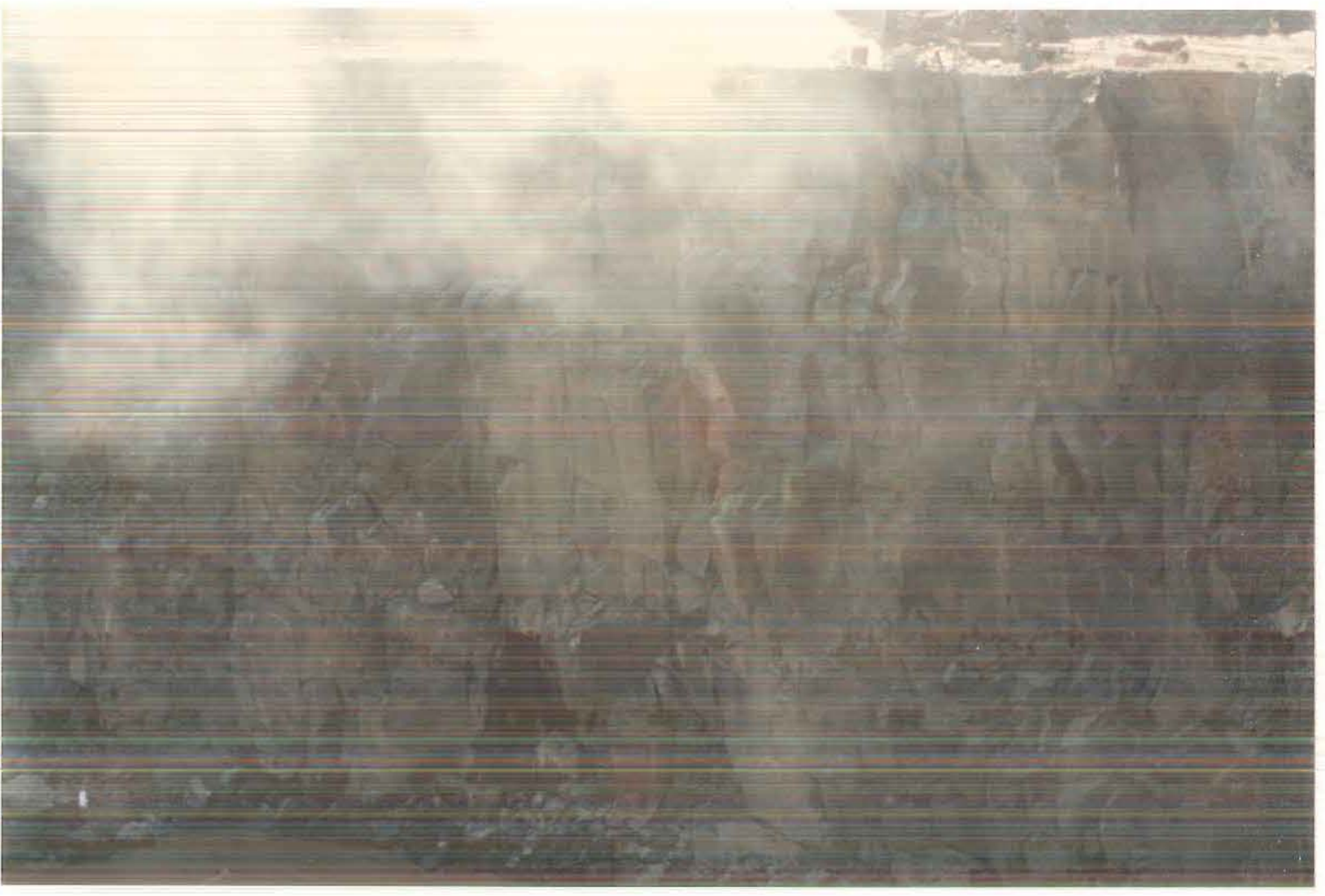

Figura I.7 - Detalhe da amostra "comercializada" pertencente a Pedreira Bandeirantes.

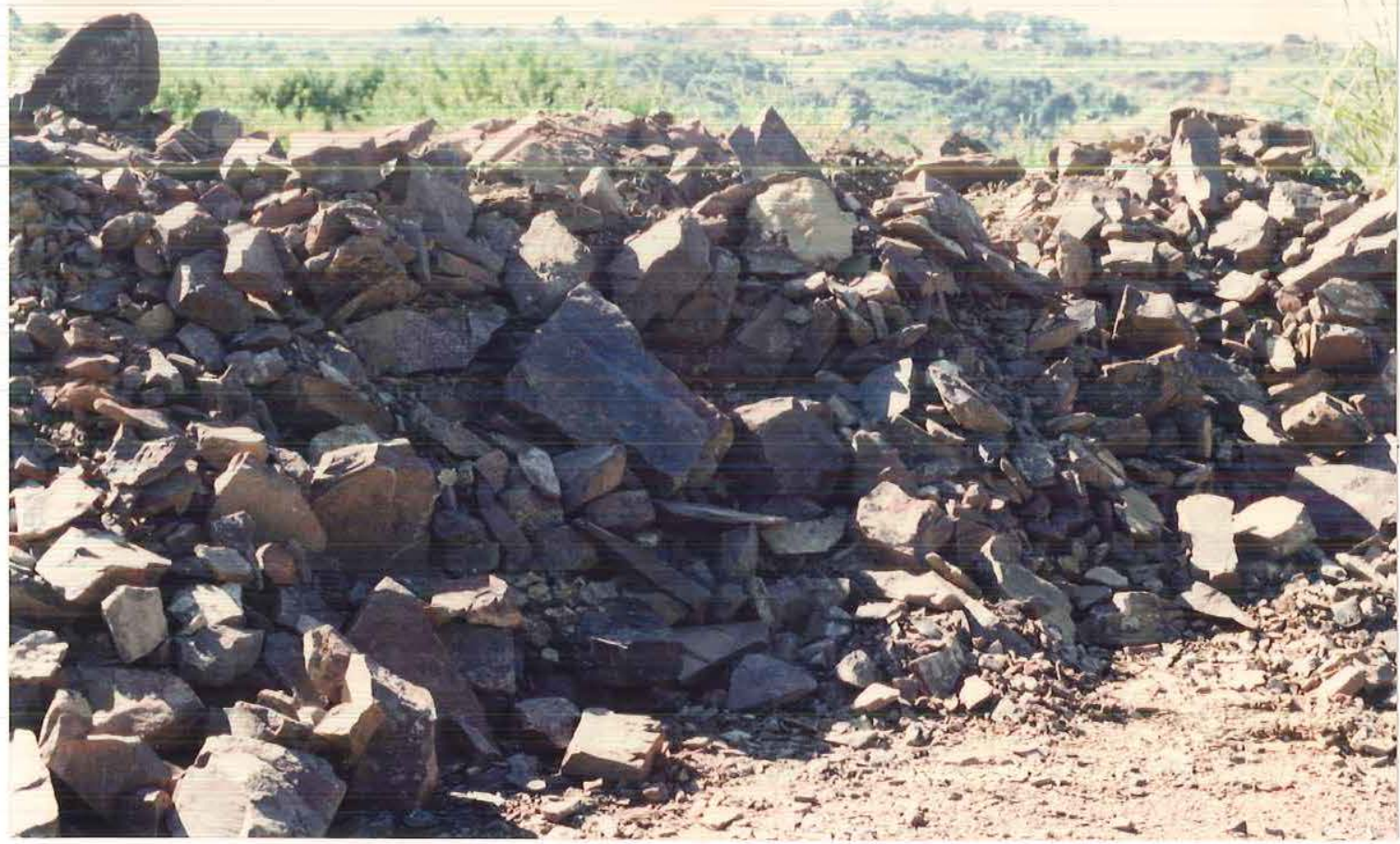

Figura I.8 - Detalhe da amostra "alterada" pertencente a Pedreira Bandeirantes. 


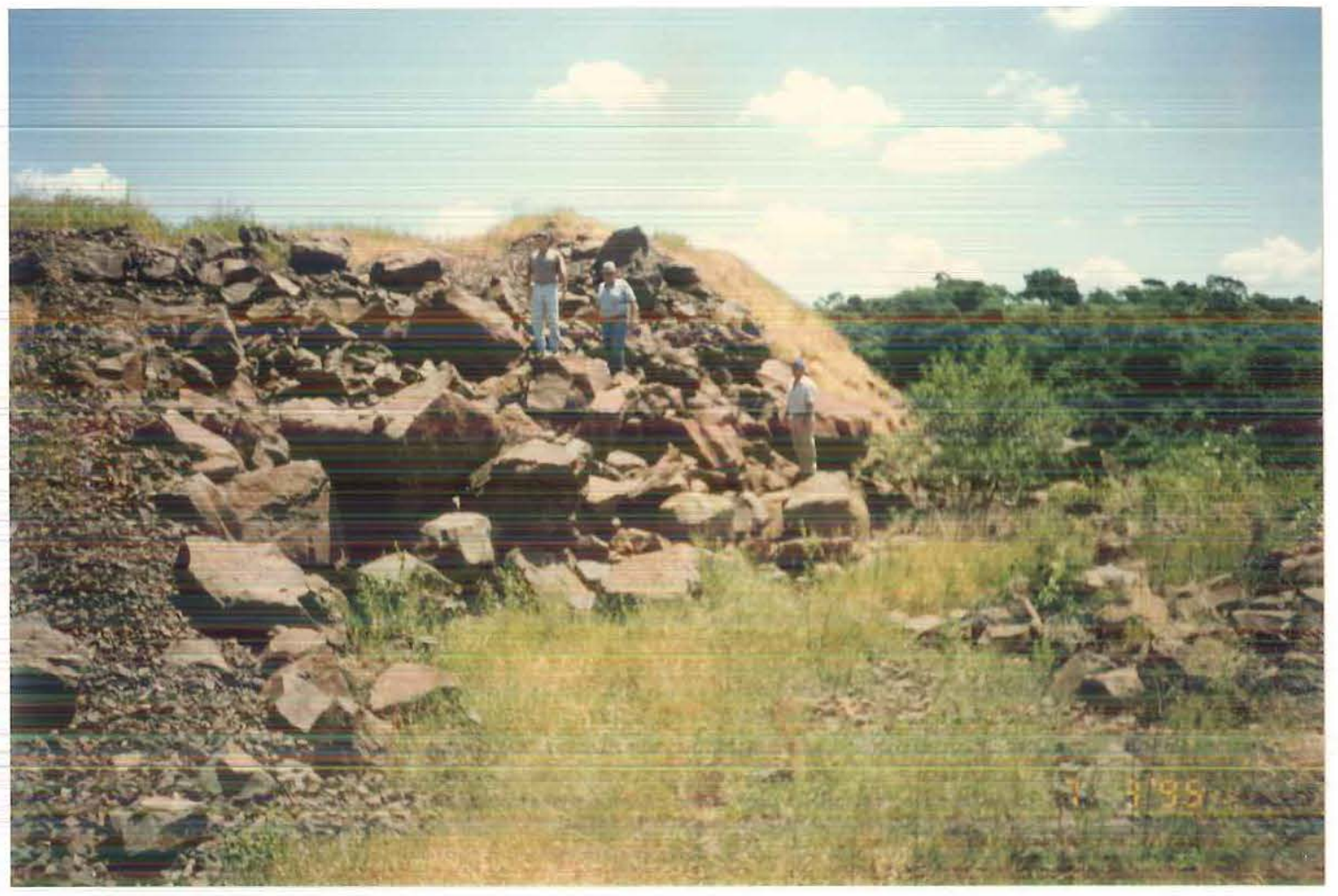

Figura I.9 - Detalhe da amostra "alterada" pertencente a Pedreira Dois Córregos. 


\section{ANEXO III}

RESULTADOS DOS ENSAIOS DE DIFRAÇ̃̃O DE RAIOS X 
Amostra 1 (rocha comercializada)

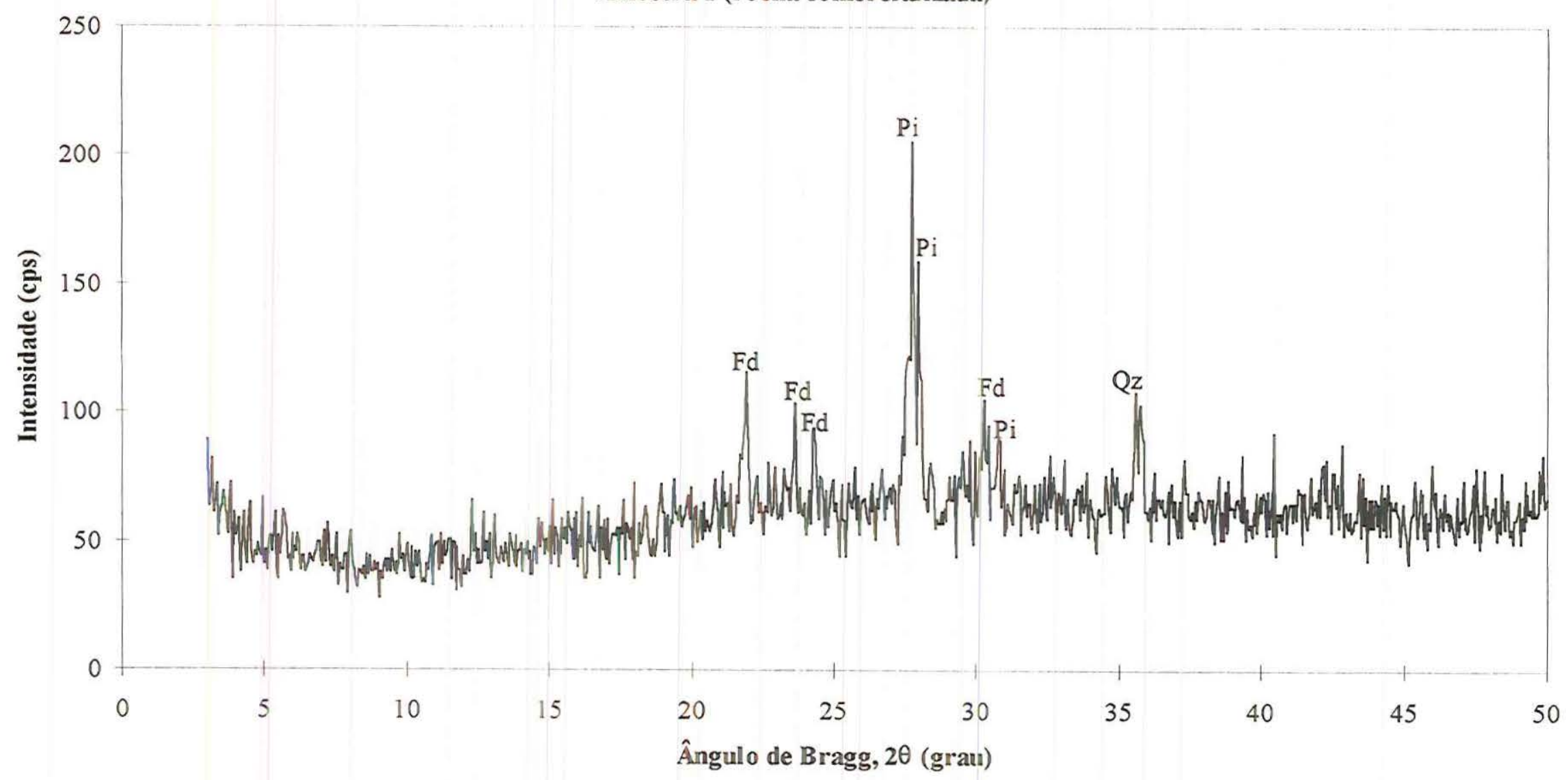

Fd: Feldspato

Pi: Piroxênio

Qz: Quartzo 


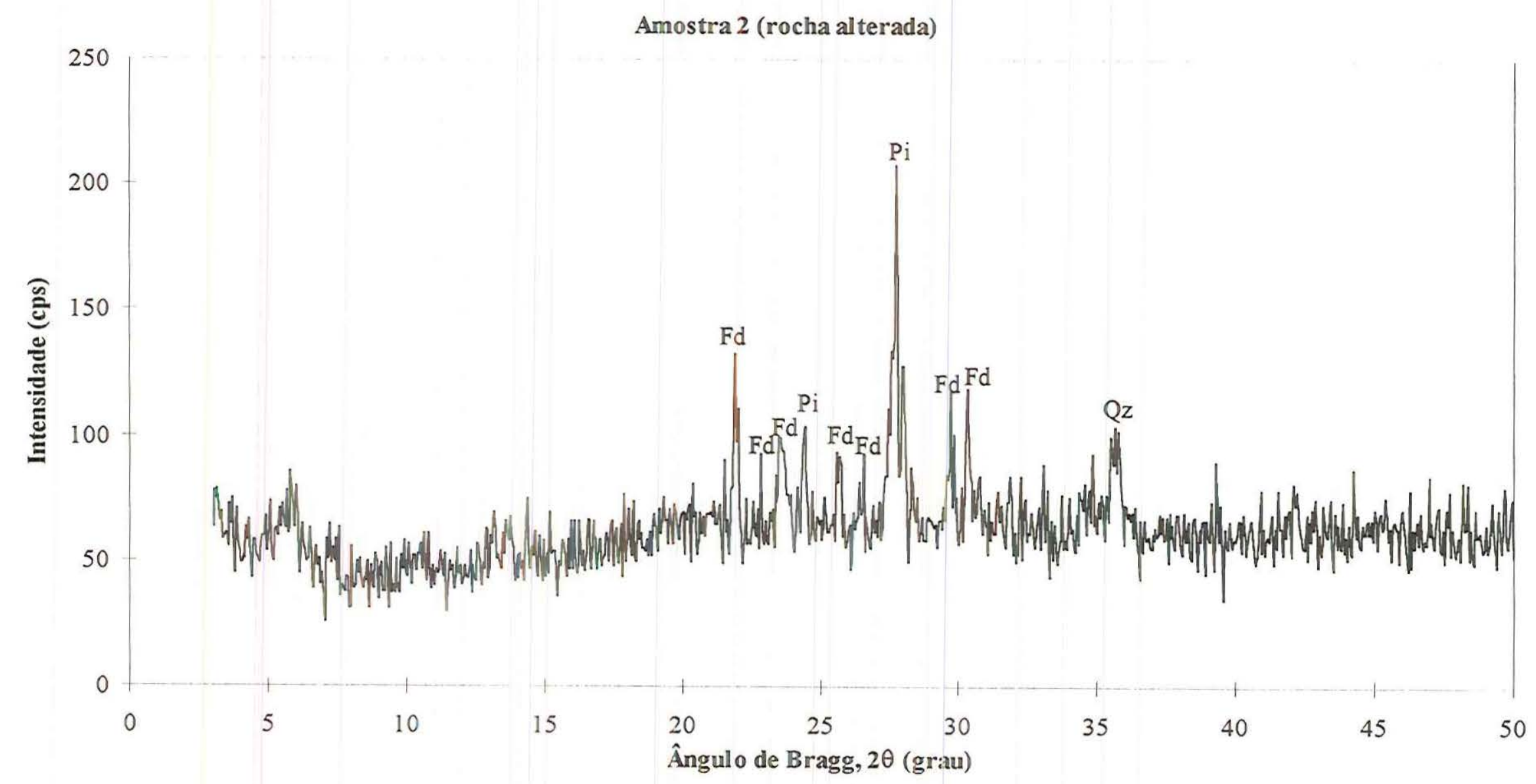

Fd: Feldspato

Pi: Piroxênio

Qz: Quartzo 
Amostra 3 (rocha comercial izada)

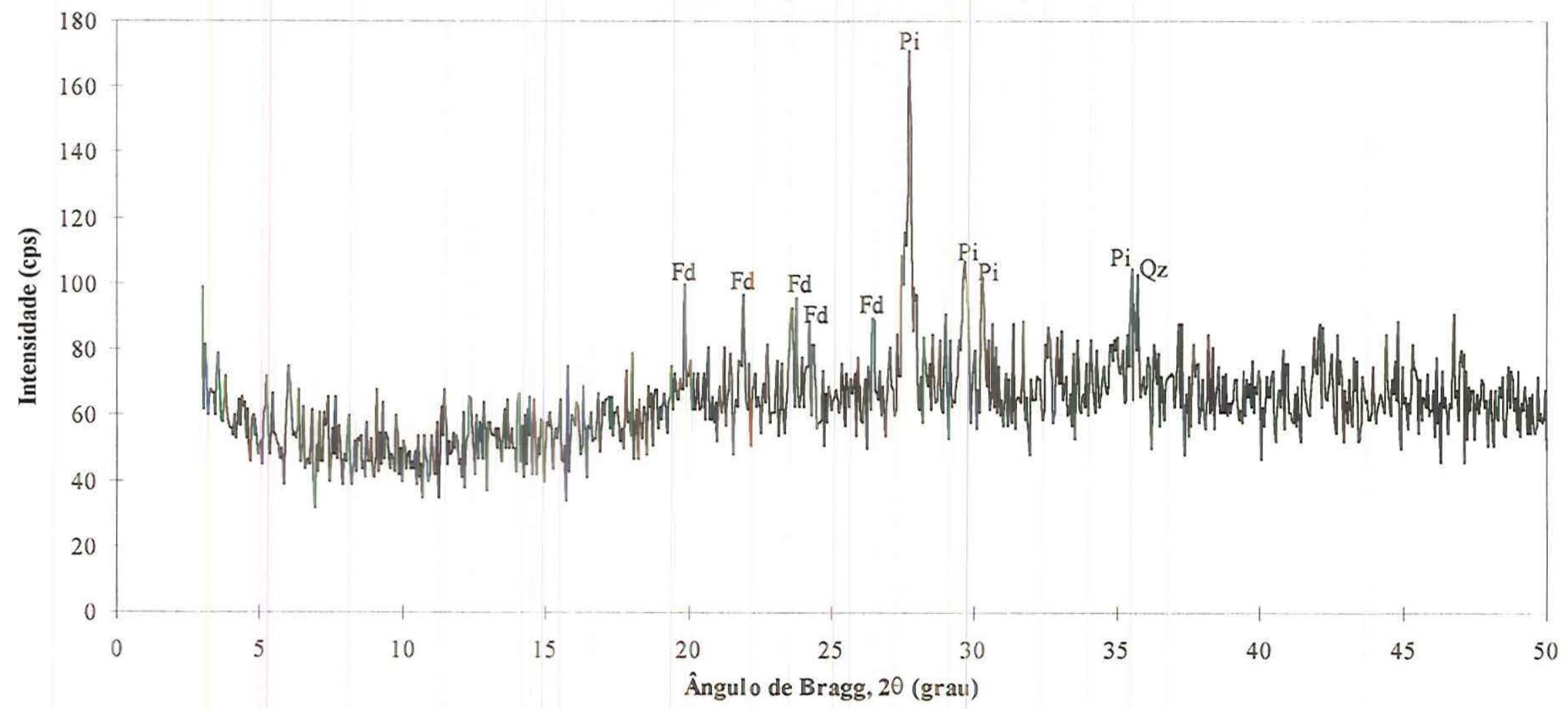

Fd: Feldspato

Pi: Piroxênio

Qz: Quartzo 


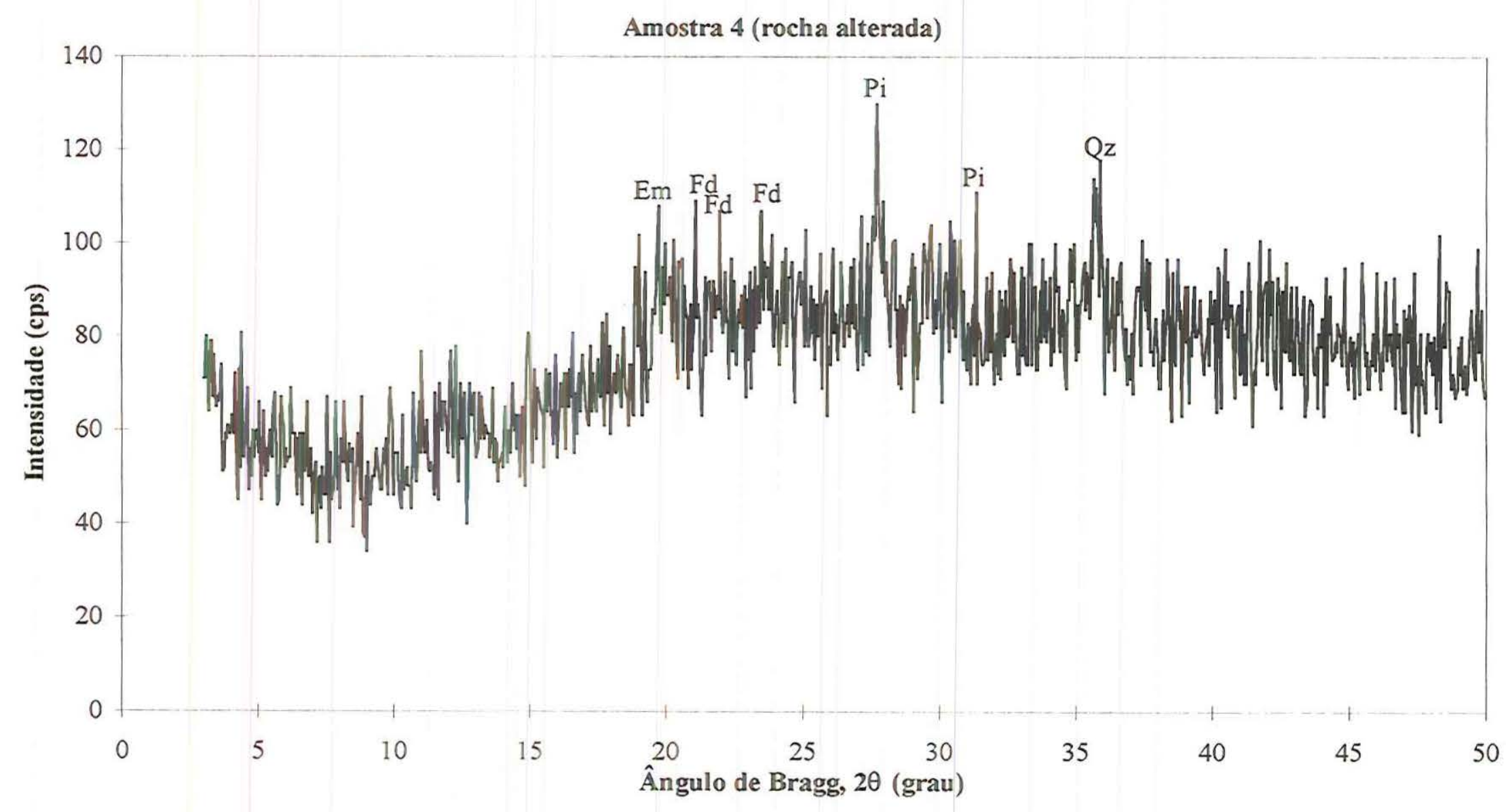

Em: Esmectita

Fd: Feldspato

Pi: Piroxênio

Qz: Quartzo 


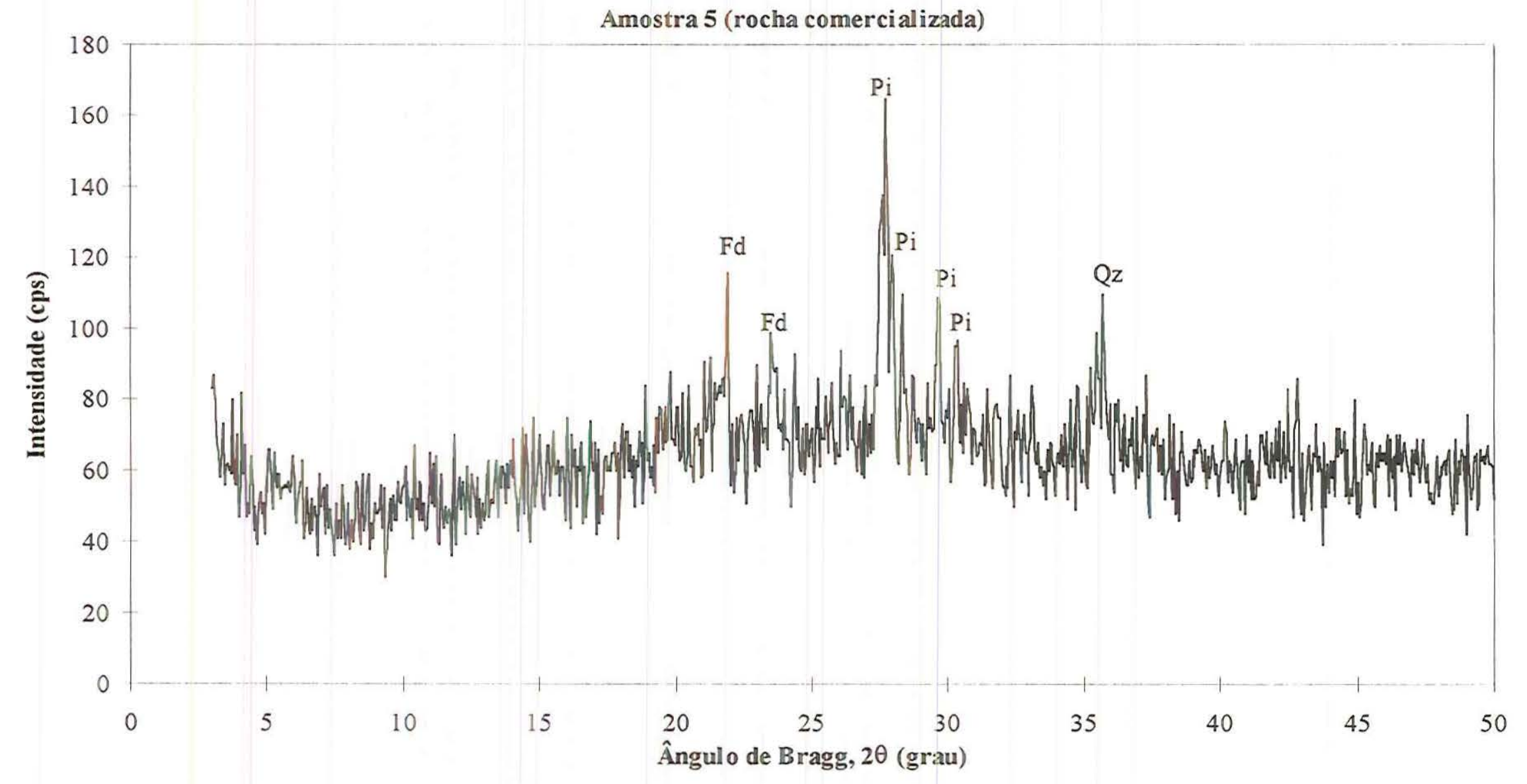

Fd: Feldspato

Pi: Piroxênio

Qz: Quartzo 
Amostra 6 (rocha alterada)

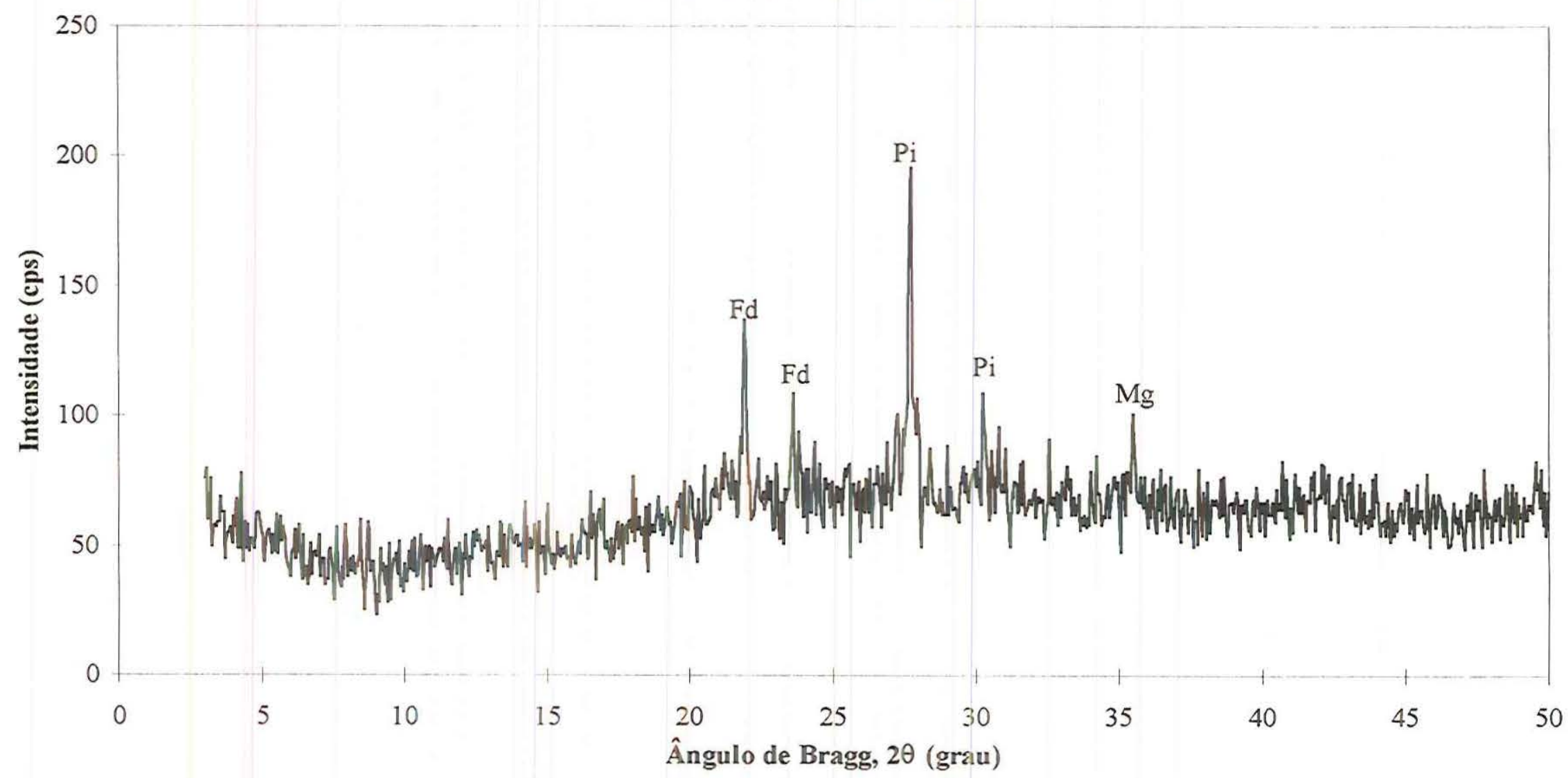

Fd: Feldspato

Mg: Magnetita

Pi: Piroxênio 
Amostra 7 (rocha comercial izada)

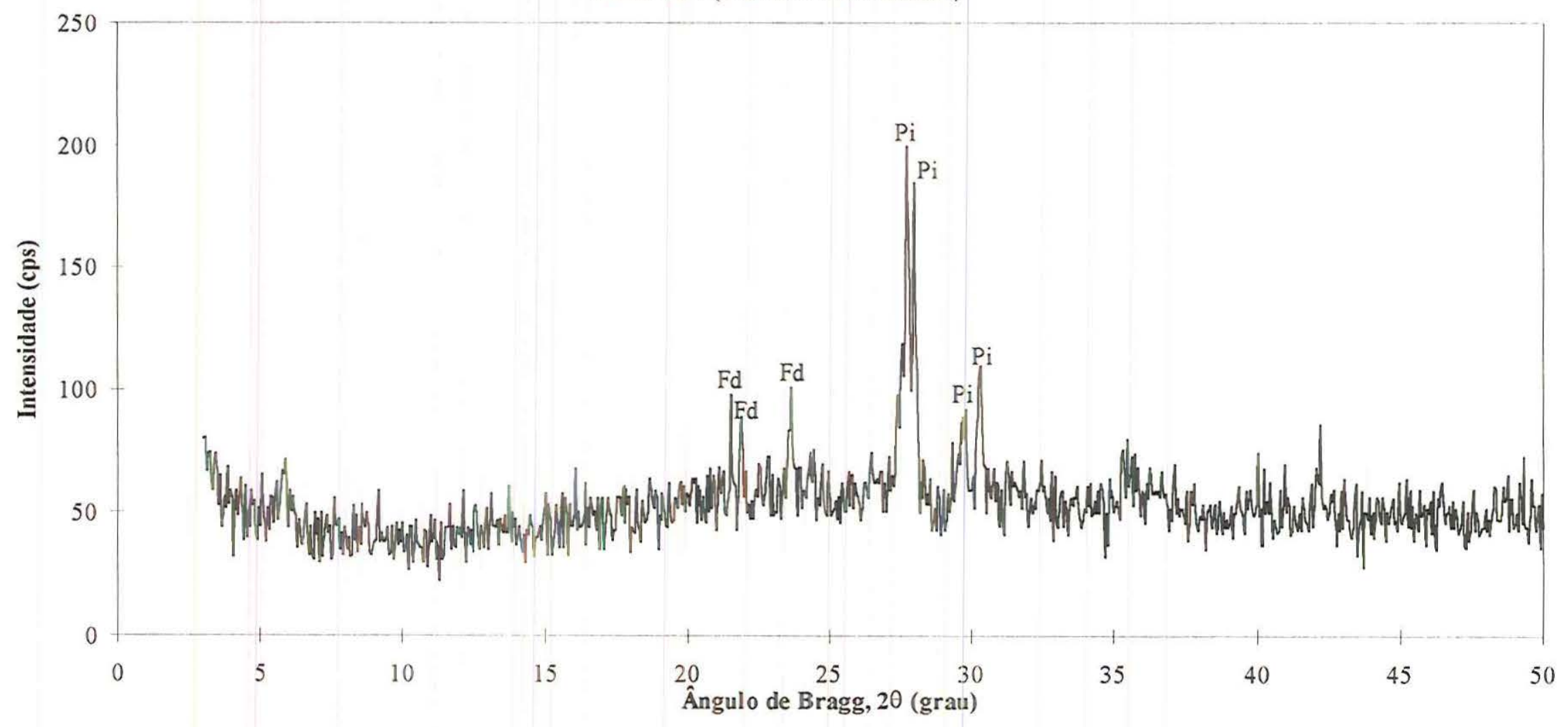

Fd: Feldspato

Pi: Piroxênio 


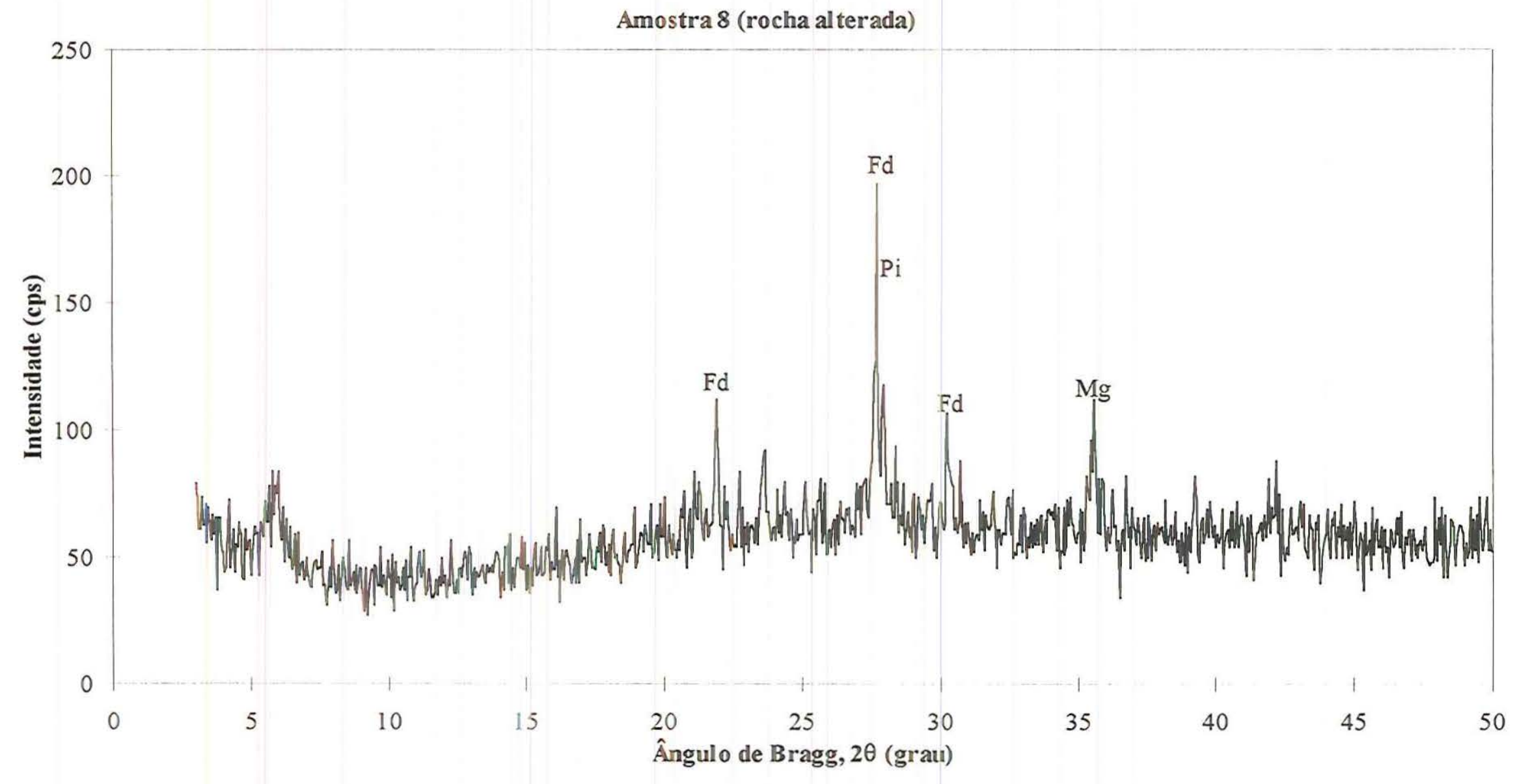

Fd: Feldspato

Mg: Magnetita

Pi: Piroxênio

Qz: Quartzo 
Amostra 10 (rocha al terada)

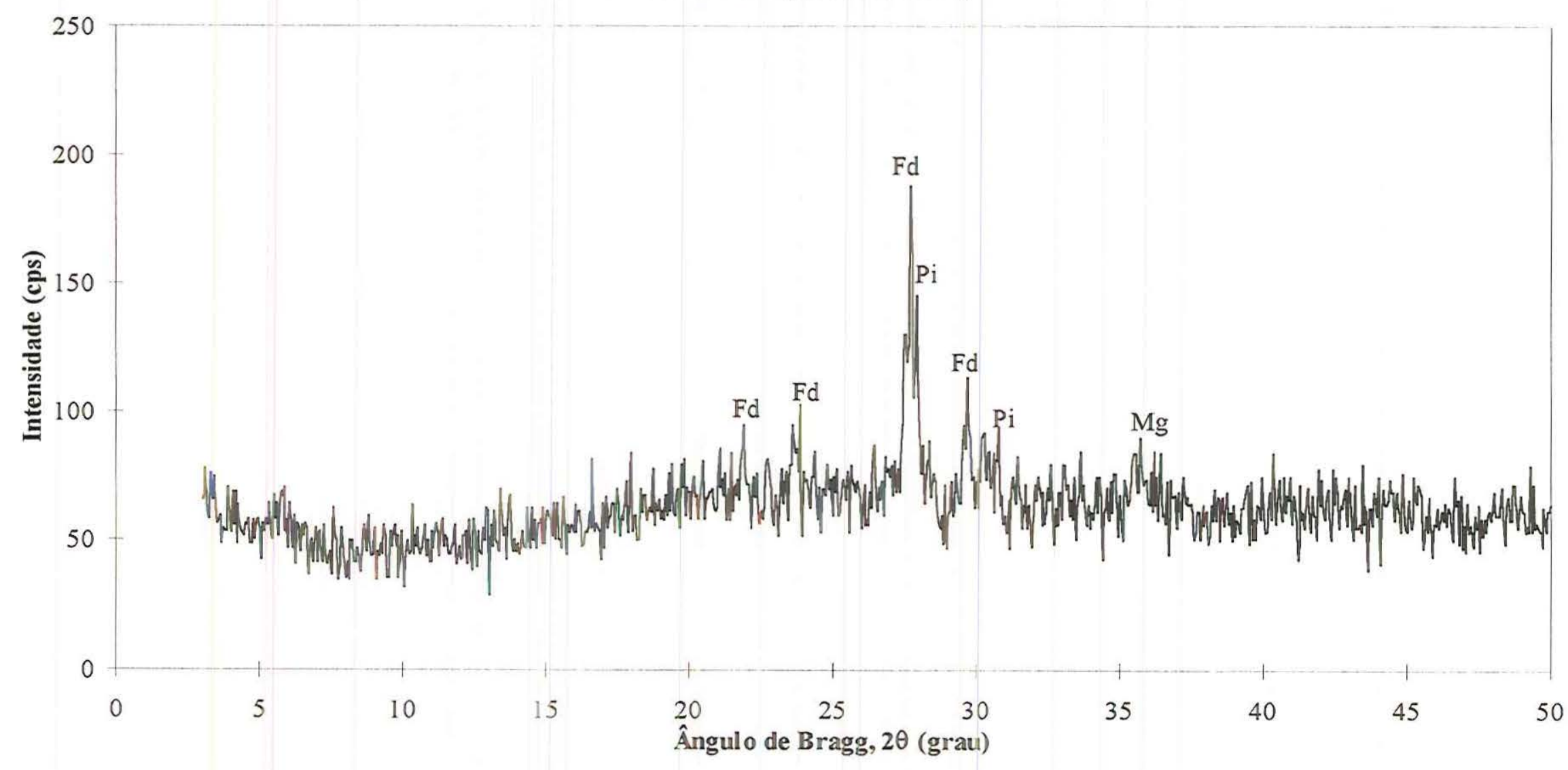

Fd: Feldspato

Mg: Magnetita

Pi: Piroxênio 


\section{ANEXO IIII}

MÉTODO DE CÁLCULO DA "ÁREA" APROXIMADA DAS AMOSTRAS E OS RESULTADOS DOS ENSAIOS DE ANÁLISE GRANULOMÉTRICA POR SEDIMENTAÇÃO 
III - Método de Cálculo da "Área" aproximada das amostras

A "área" aproximada de cada uma das amostra foi calculada a partir das curvas de distribuição granulométrica de $\phi_{1}(0,002 \mathrm{~mm})$ a $\phi_{10}(0,074 \mathrm{~mm})$, obtidas do ensaio de granulometria conjunta, de acordo com o procedimento descrito a seguir.

Divide-se o intervalo arbitrário $\left(\phi_{1}\right.$ a $\left.\phi_{10}\right)$ em 10 subintervalos como mostra a Figura III.1, onde têm-se, a título de exemplo, o seguinte:

$$
\Delta \phi=\frac{\phi_{5}+\phi_{6}}{2}
$$

$$
\Delta \mathrm{P}=\mathrm{P}_{5}-\mathrm{P}_{6}
$$

Admitindo-se que as partículas são esféricas, define-se a sua área, como:

$$
\mathrm{A}_{\text {patticuls }}=\frac{\mathrm{A}}{\mathrm{V} \times \rho}=\frac{3}{\Delta \phi \times \rho}
$$

onde:

A $_{\text {particula: }}$ área da partícula $\left(\mathrm{cm}^{2} / \mathrm{g}\right)$;

A: área da esfera $\left(\mathrm{cm}^{2}\right)$;

$\mathrm{V}$ : volume da esfera $\left(\mathrm{cm}^{3}\right)$;

$\Delta \phi:$ diâmetros médio das partículas $(\mathrm{cm})$;

$\rho$ : peso específico $\left(\mathrm{g} / \mathrm{cm}^{3}\right)$.

Então, define-se a "Área" aproximada total como sendo:

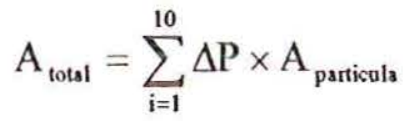




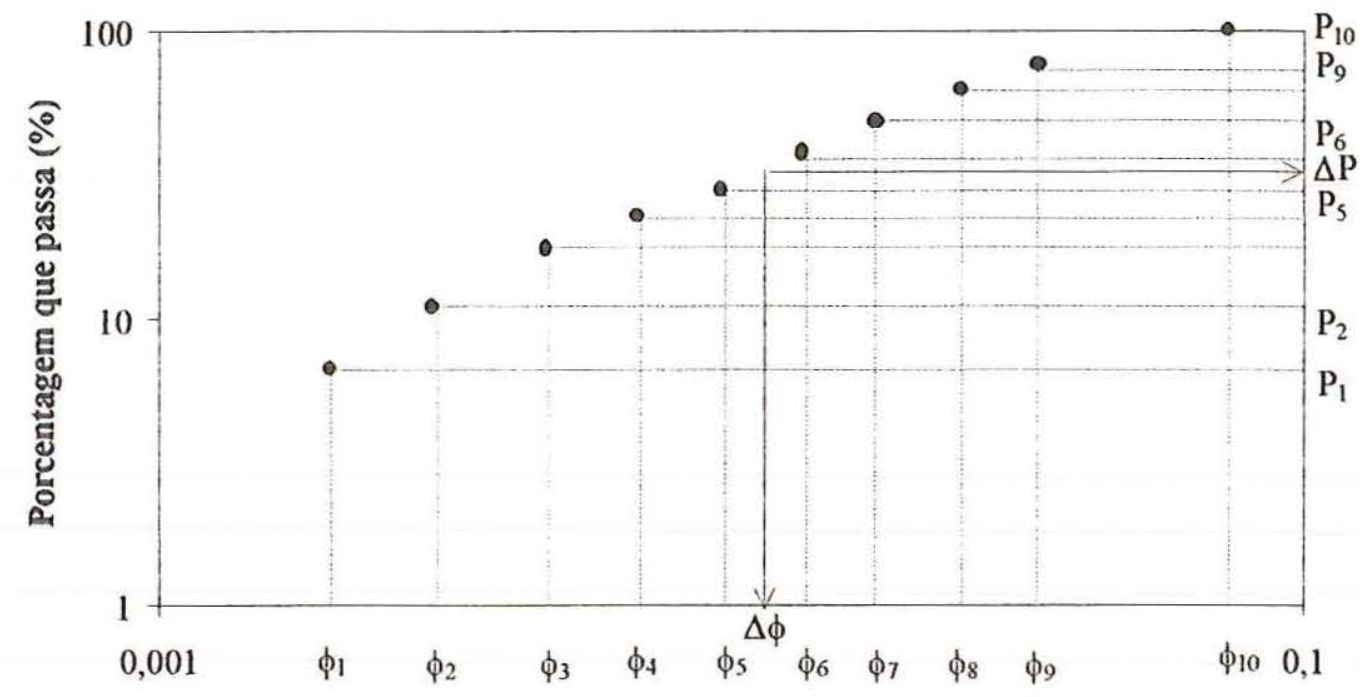

Diâmetro dos grãos (mmin)

Figura III.1 - Curva granulométrica utilizada e os seus respectivos pontos para o cálculo aproximado da "área”.

Este método de cálculo para a "área" não é preciso, pois nele são considerados apenas os diâmetros $\mathrm{e}$ as porcentagens efetivamente medidos no ensaio de granulometria. Assim sendo, neste processo não se consideram aquelas partículas cujos diâmetros são inferiores ao menor medido $(0,002 \mathrm{~mm})$ e que, na verdade, têm maior superficie especifica. 
Quadro III.1 - Análise granulométrica por Sedimentação e o valor de azul (Va) para o par de amostras 1 e 2 (Pedreira Santo Antonio).

\begin{tabular}{|c|c|c|}
\cline { 2 - 3 } \multicolumn{1}{c|}{} & \multicolumn{2}{c|}{ Porcentagem que passa (\%) } \\
\hline$\phi(\mathrm{mm})$ & Amostra 1 (comercializada) & Amostra 2 (alterada) \\
\hline 0,074 & 100,00 & 100,00 \\
\hline 0,034 & 57,29 & 63,39 \\
\hline 0,025 & 41,25 & 53,94 \\
\hline 0,017 & 32,05 & 41,64 \\
\hline 0,013 & 24,08 & 32,54 \\
\hline 0,009 & 19,56 & 25,58 \\
\hline 0,007 & 15,31 & 18,09 \\
\hline 0,005 & 12,03 & 16,67 \\
\hline 0,003 & 9,27 & 10,72 \\
\hline 0,002 & 5,78 & 9,05 \\
\hline $\mathrm{Va}(\mathrm{mg} / \mathrm{g})$ & 9,43 & 17,71 \\
\hline
\end{tabular}

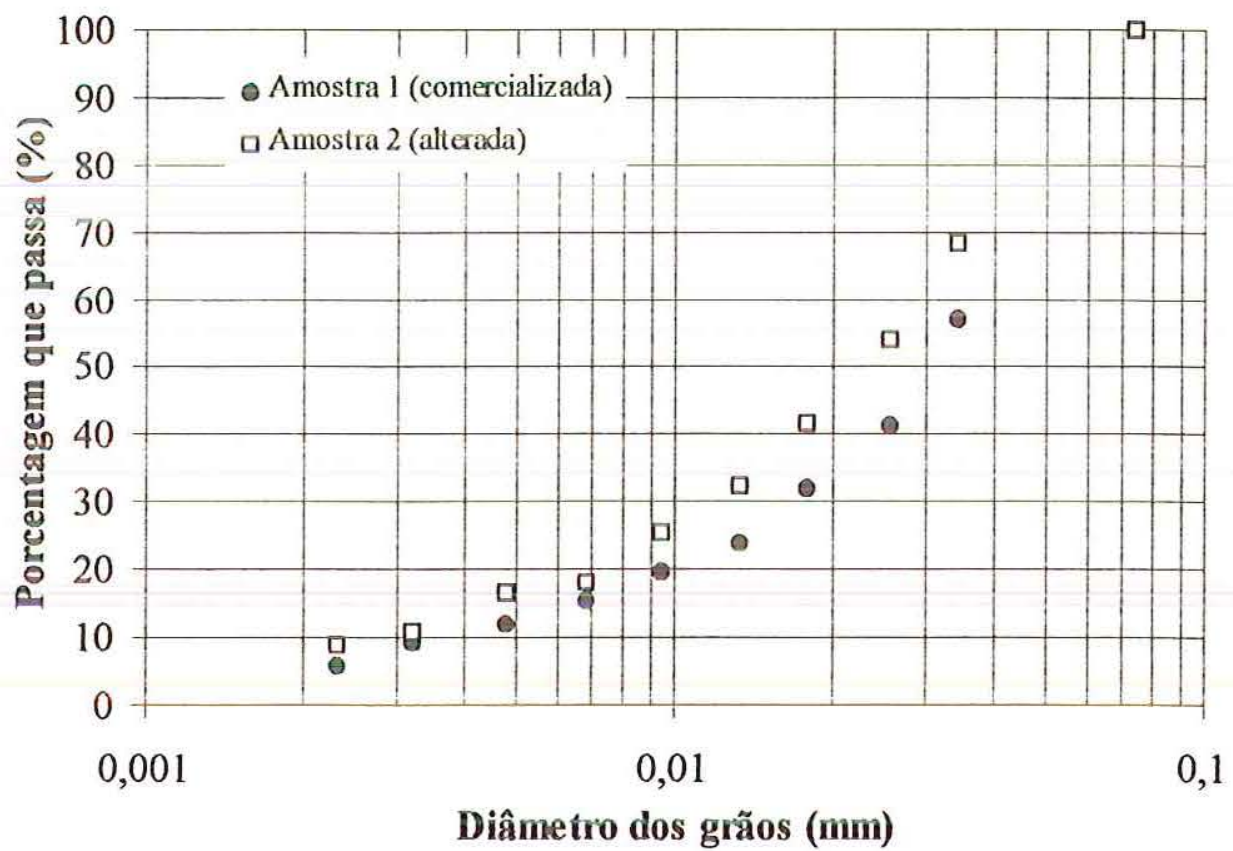

Figura III.2 - Curva granulométrica das amostras 1 (comercializada) e 2 (alterada). 
Quadro III.2 - Análise granulométrica por Sedimentação e o valor de azul (Va) para o par de amostras 3 e 4 (Pedreira Multipedras).

\begin{tabular}{|c|c|c|}
\cline { 2 - 3 } \multicolumn{1}{c|}{} & \multicolumn{2}{c|}{ Porcentagem que passa (\%) } \\
\hline$\phi(\mathrm{mm})$ & Amostra 3 (comercializada) & Amostra 4 (alterada) \\
\hline 0,074 & 100,00 & 100,00 \\
\hline 0,034 & 65,59 & 75,73 \\
\hline 0,025 & 55,20 & 62,32 \\
\hline 0,018 & 43,50 & 48,91 \\
\hline 0,013 & 34,41 & 38,19 \\
\hline 0,010 & 24,02 & 28,00 \\
\hline 0,007 & 16,74 & 22,64 \\
\hline 0,005 & 11,85 & 17,59 \\
\hline 0,003 & 8,03 & 10,96 \\
\hline 0,002 & 3,87 & 6,67 \\
\hline $\mathrm{Va}(\mathrm{mg} / \mathrm{g})$ & 11,82 & 20,39 \\
\hline & & \\
\hline
\end{tabular}

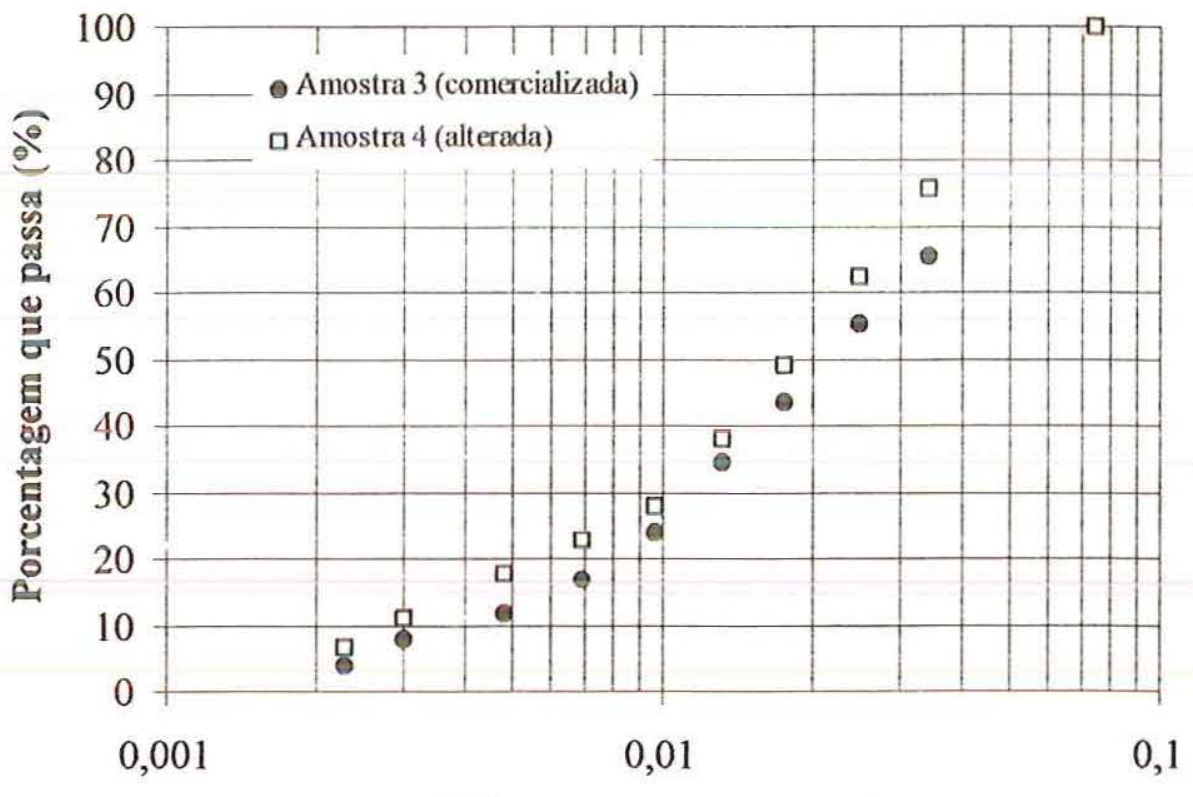

Diâmetro dos grãos (mm)

Figura III.3 - Curva granulométrica das amostras 3 (comercializada) e 4 (alterada). 
Quadro III.3 - Análise granulométrica por Sedimentação e o valor de azul (Va) para o par de amostras 5 e 6 (Pedreira Ouro Fino).

\begin{tabular}{|c|c|c|}
\cline { 2 - 3 } \multicolumn{1}{c|}{} & \multicolumn{2}{c|}{ Porcentagem que passa (\%) } \\
\hline$\phi(\mathrm{mm})$ & Amostra 5 (comercializada) & Amostra 6 (alterada) \\
\hline 0,074 & 100,00 & 100,00 \\
\hline 0,035 & 69,04 & 65,43 \\
\hline 0,025 & 58,31 & 51,93 \\
\hline 0,018 & 43,56 & 41,14 \\
\hline 0,013 & 35,51 & 33,04 \\
\hline 0,010 & 26,13 & 25,48 \\
\hline 0,007 & 19,96 & 20,89 \\
\hline 0,005 & 15,45 & 15,01 \\
\hline 0,003 & 11,50 & 11,03 \\
\hline 0,002 & 9,35 & 9,41 \\
\hline Va (mg/g) & 11,01 & 13,78 \\
\hline
\end{tabular}

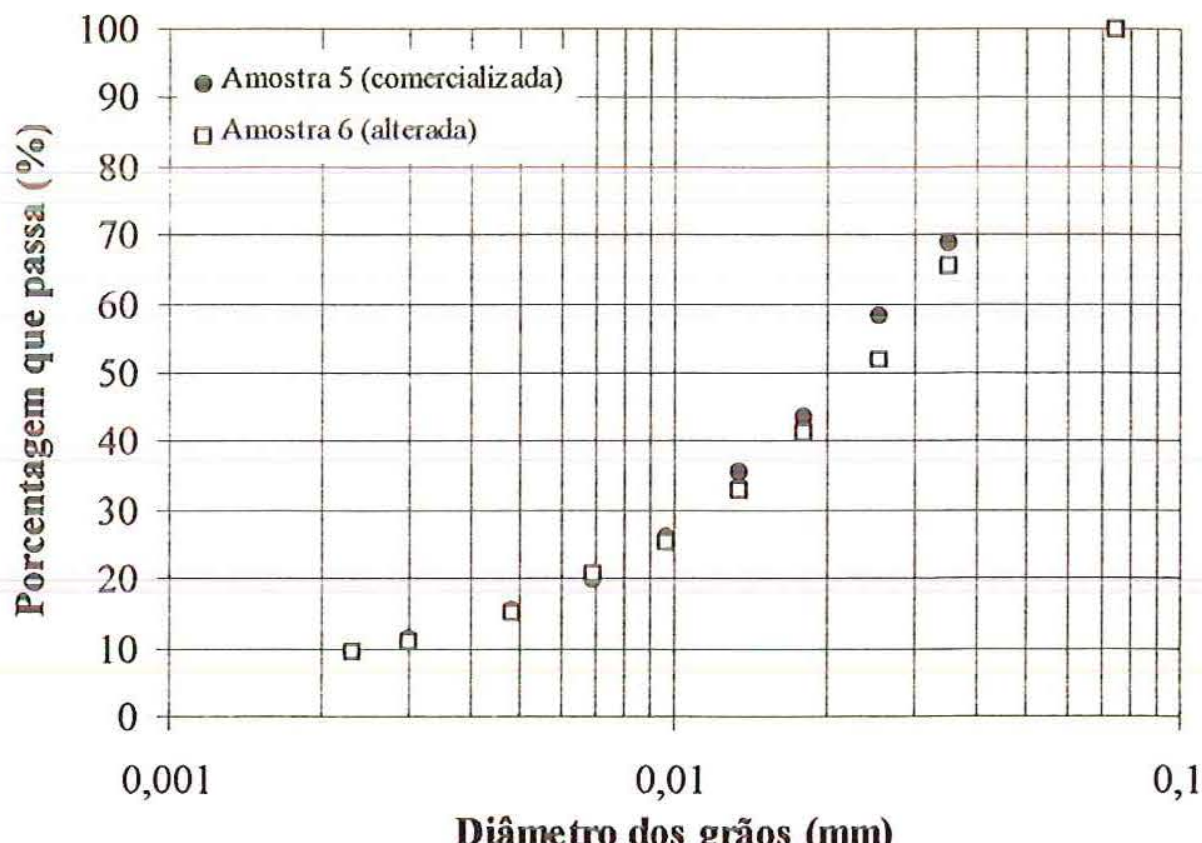

Figura III.4 - Curva granulométrica das amostras 5 (comercializada) e 6 (alterada). 
Quadro III.4 - Análise granulométrica por Sedimentação e o valor de azul (Va) para o par de amostras 7 e 8 (Pedreira Ouro Fino).

\begin{tabular}{|c|c|c|}
\cline { 2 - 3 } \multicolumn{1}{c|}{} & \multicolumn{2}{c|}{ Porcentagem que passa (\%) } \\
\hline$\phi(\mathrm{mm})$ & Amostra 7 (comercializada) & Amostra 8 (alterada) \\
\hline 0,074 & 100,00 & 100,00 \\
\hline 0,034 & 57,53 & 69,46 \\
\hline 0,024 & 44,78 & 59,00 \\
\hline 0,017 & 32,54 & 44,62 \\
\hline 0,013 & 24,38 & 34,94 \\
\hline 0,009 & 16,73 & 27,62 \\
\hline 0,007 & 12,14 & 21,08 \\
\hline 0,005 & 7,47 & 15,51 \\
\hline 0,003 & 3,80 & 11,21 \\
\hline 0,002 & 3,00 & 6,99 \\
\hline Va (mg/g) & 4,57 & 12,92 \\
\hline
\end{tabular}

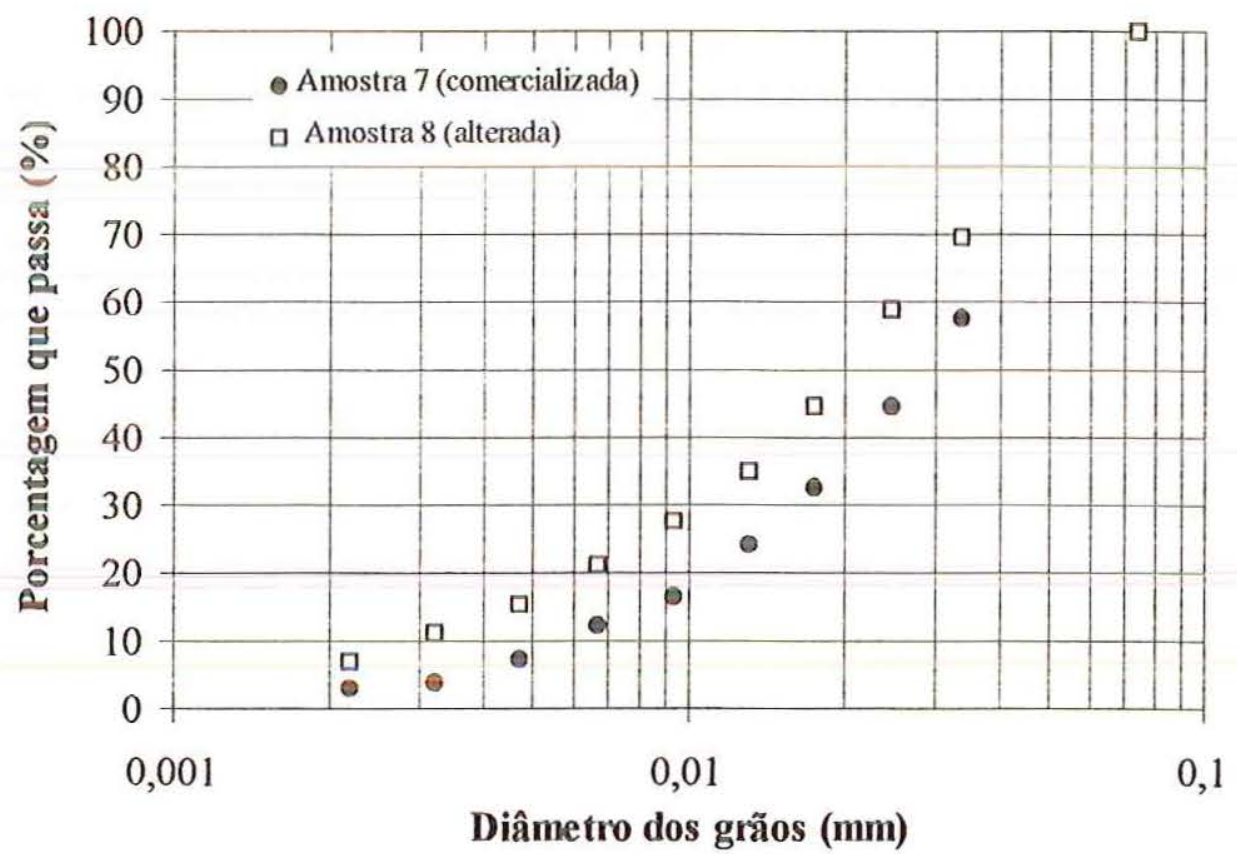

Figura III.5 - Curva granulométrica das amostras 7 (comercializada) e 8 (alterada). 
Quadro III.5 - Análise granulométrica por Sedimentação e o valor de azul (Va) para o a amostra 10 (Pedreira Dois Córregos).

\begin{tabular}{|c|c|}
\cline { 2 - 2 } \multicolumn{1}{c|}{} & Porcentagem que passa (\%) \\
\hline$\phi(\mathrm{mm})$ & Amostra 10 (alterada) \\
\hline 0,074 & 100,00 \\
\hline 0,034 & 67,46 \\
\hline 0,025 & 51,42 \\
\hline 0,018 & 36,72 \\
\hline 0,013 & 27,90 \\
\hline 0,010 & 19,35 \\
\hline 0,007 & 12,67 \\
\hline 0,005 & 10,85 \\
\hline 0,003 & 5,58 \\
\hline 0,002 & 1,31 \\
\hline Va (mg/g) & 5,77 \\
\hline
\end{tabular}

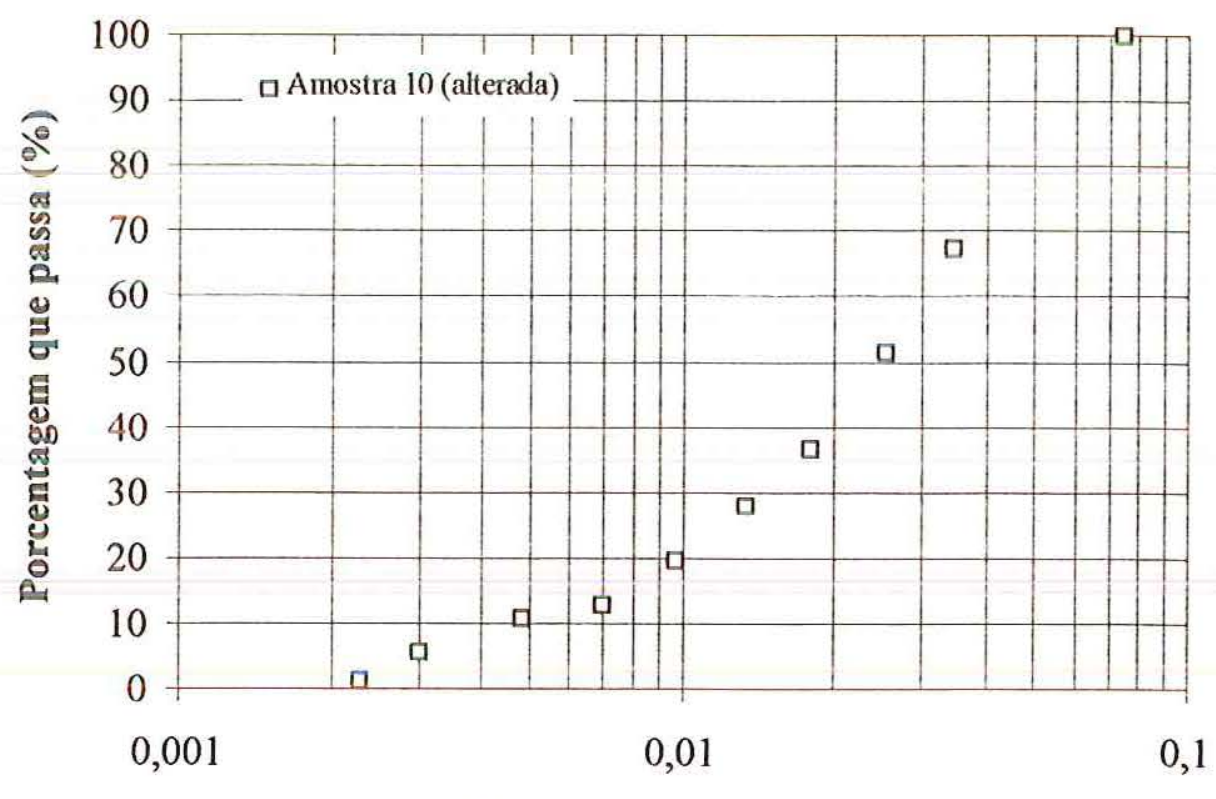

Diâmetro dos grãos (mm)

Figura III.6 - Curva granulométrica da amostra 10 (alterada). 


\begin{abstract}
ANEXO IV
FOTOS DOS RESULTADOS DO ENSAIO DE ADESIVIDADE DE AGREGADO GRAÚDO A LIGANTE BETUMINOSO
\end{abstract}




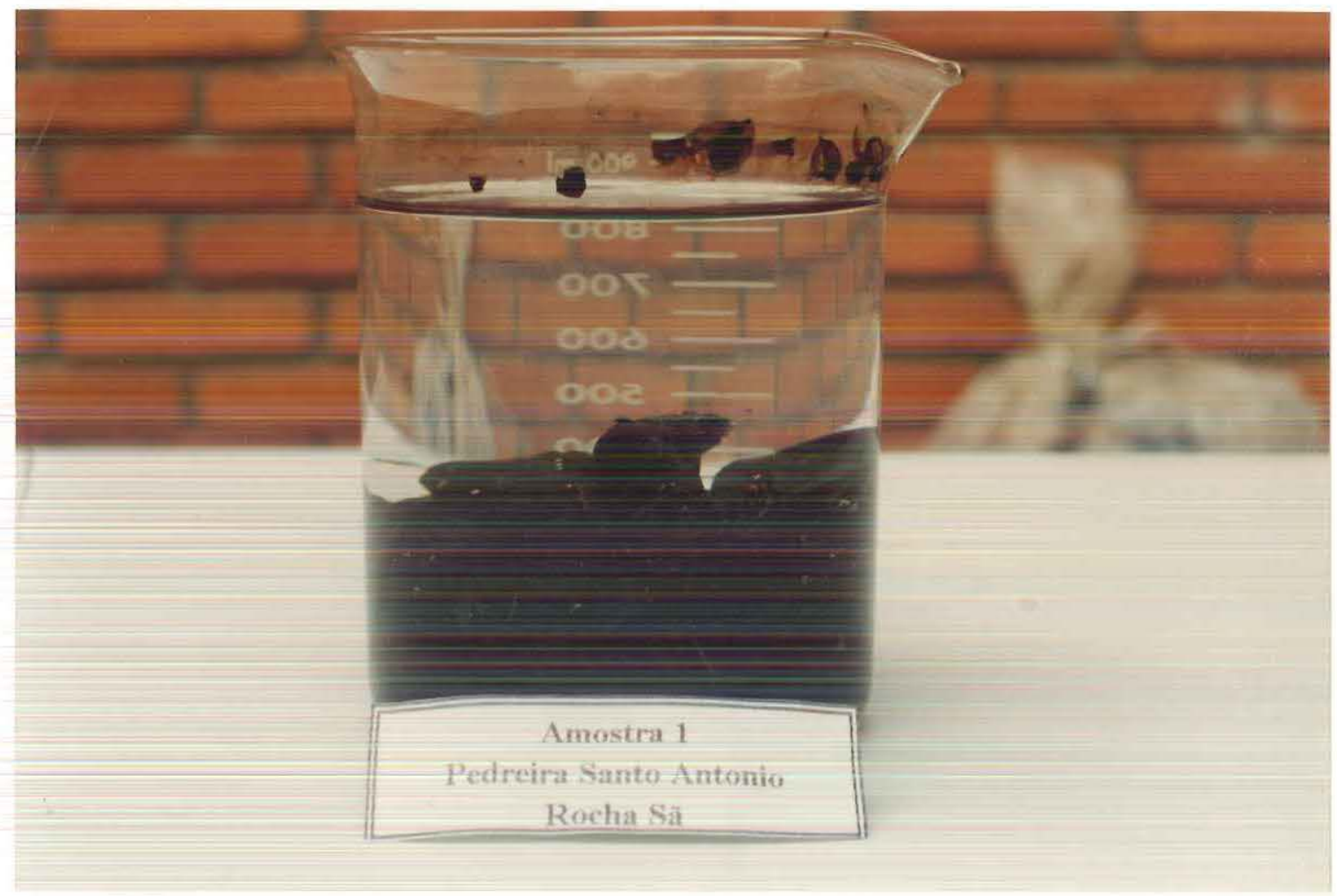

Figura IV.1 - Aspectos do ensaio de adesividade de agregado graúdo para a amostra 1 ("comercializada").

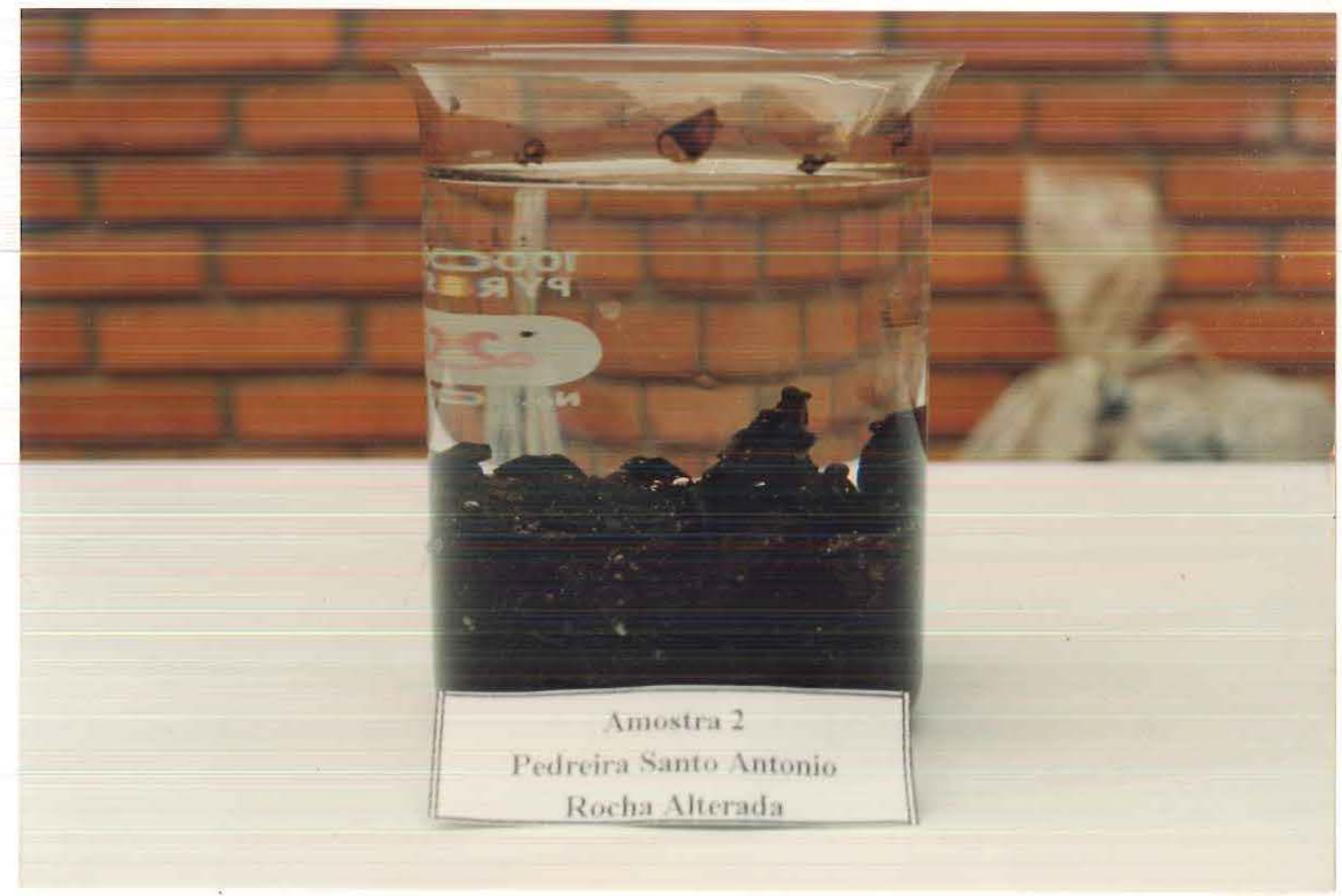

Figura IV.2 - Aspectos do ensaio de adesividade de agregado graúdo para a amostra 2 ("alterada"). 


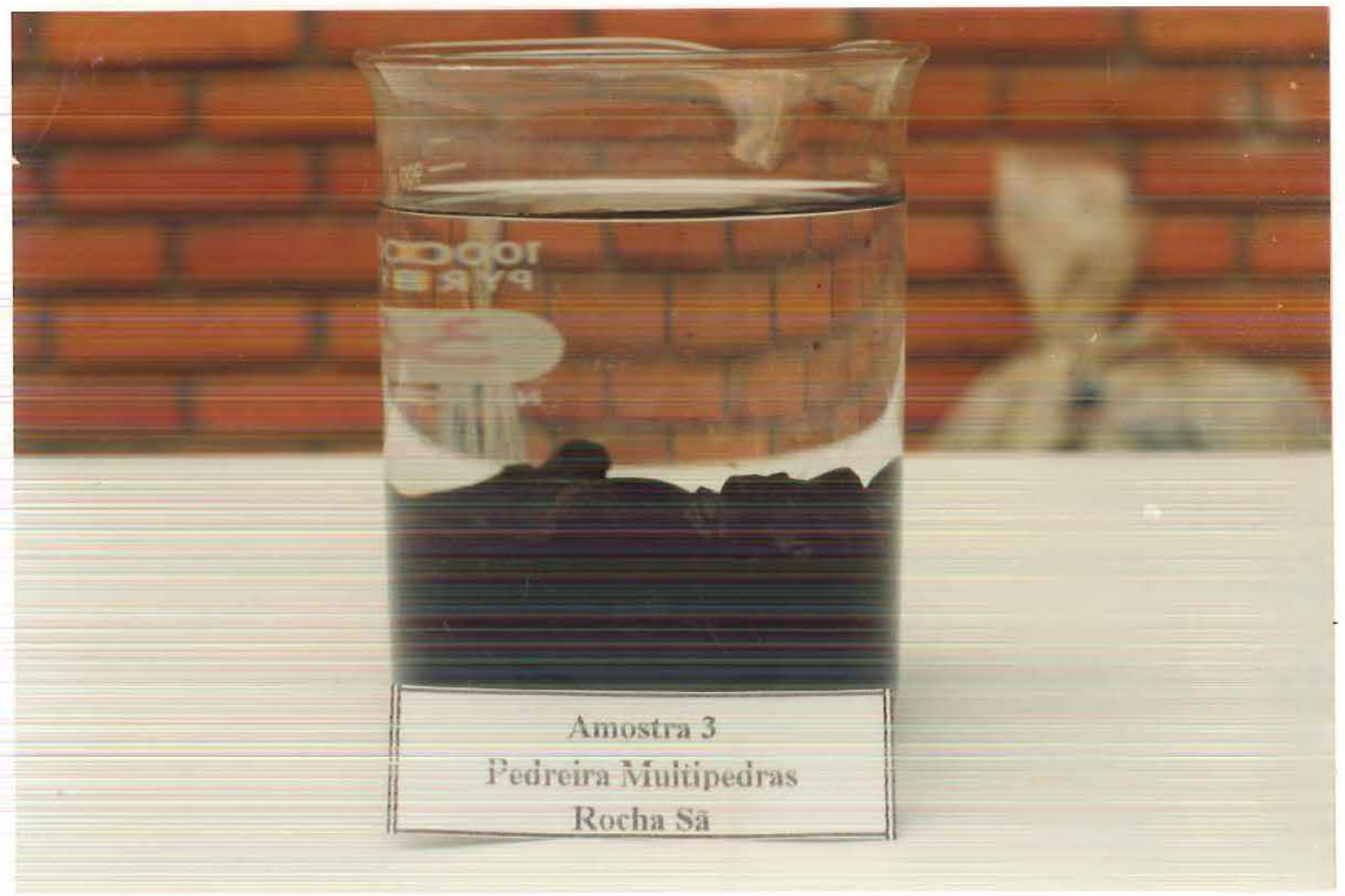

Figura IV.3 - Aspectos do ensaio de adesividade de agregado graúdo para a amostra 3 ("comercializada").

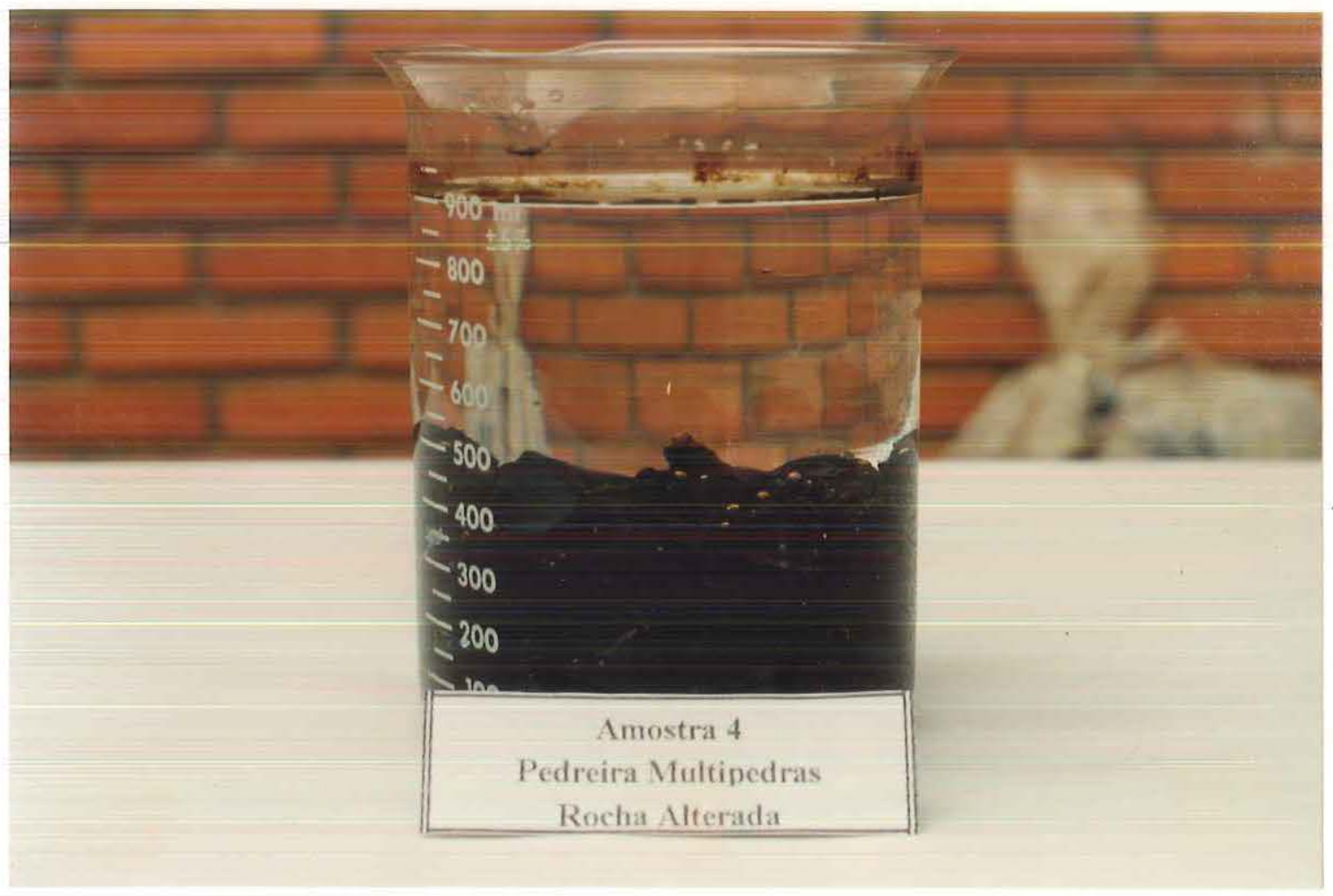

Figura IV.4 - Aspectos do ensaio de adesividade de agregado graúdo para a amostra 4 ("alterada"). 


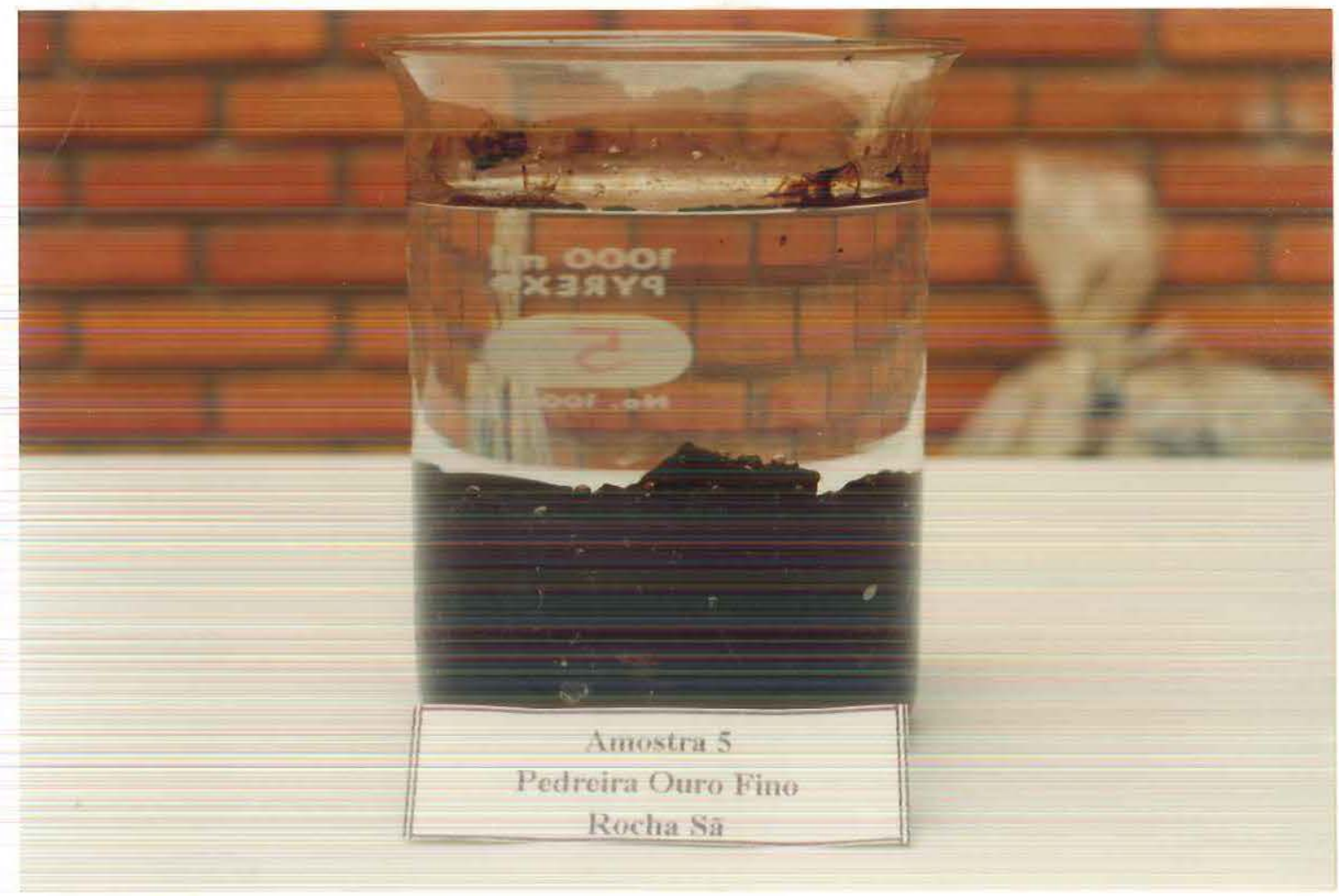

Figura IV.5 - Aspectos do ensaio de adesividade de agregado graúdo para a amostra 5 ("comercializada").

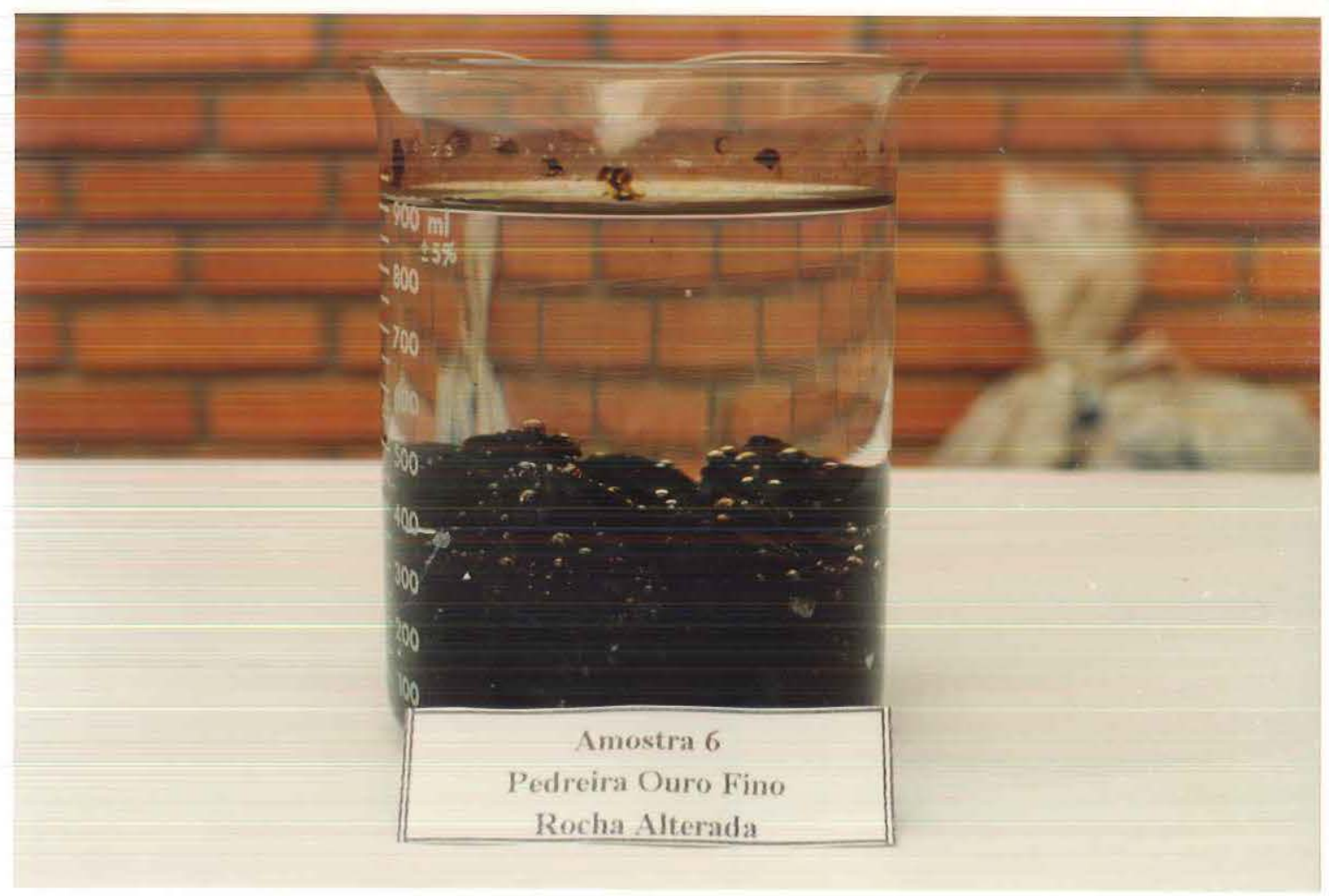

Figura IV.6 - Aspectos do ensaio de adesividade de agregado graúdo para a amostra 6 ("alterada"). 


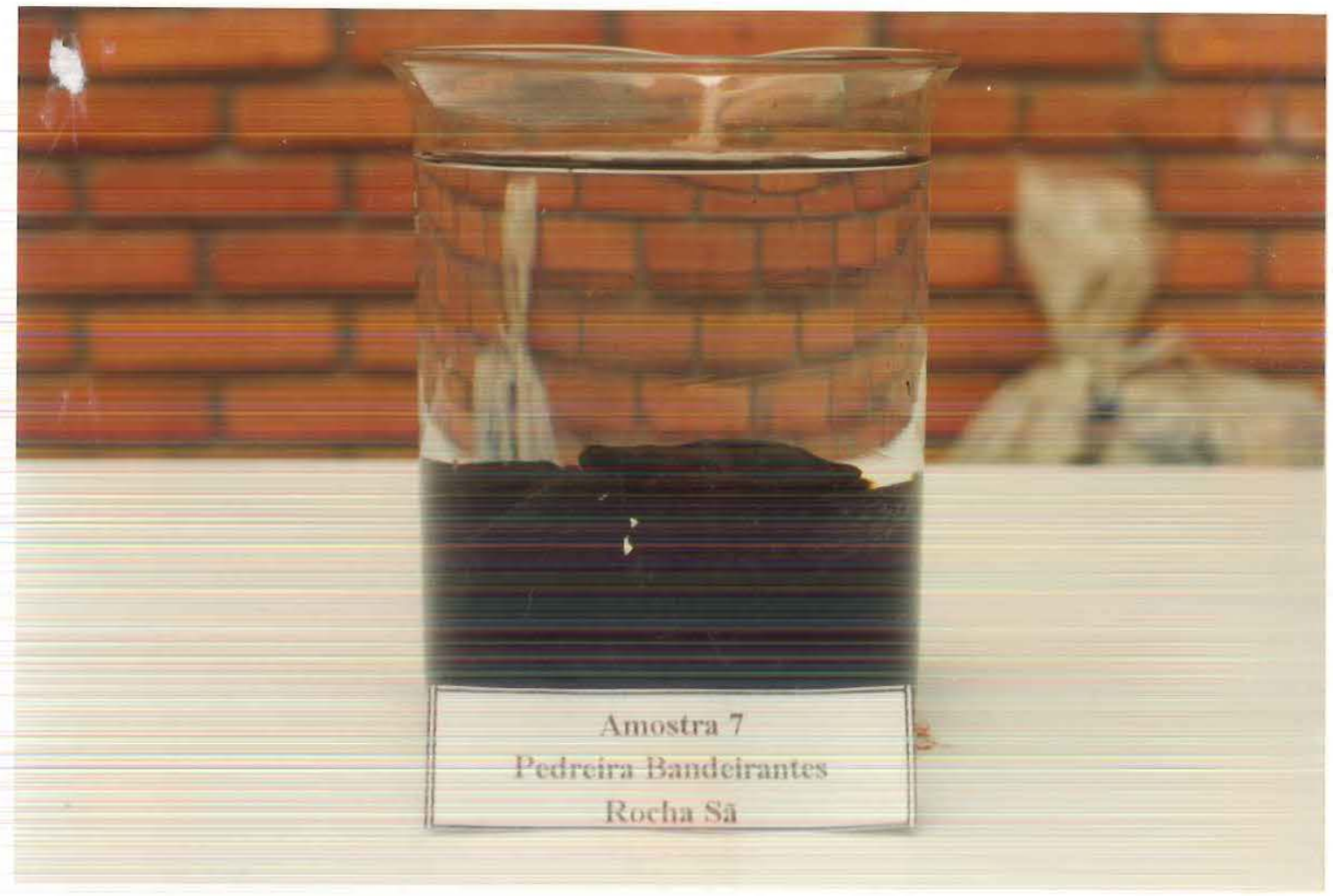

Figura IV.7 - Aspectos do ensaio de adesividade de agregado graúdo para a amostra 7 ("comercializada").

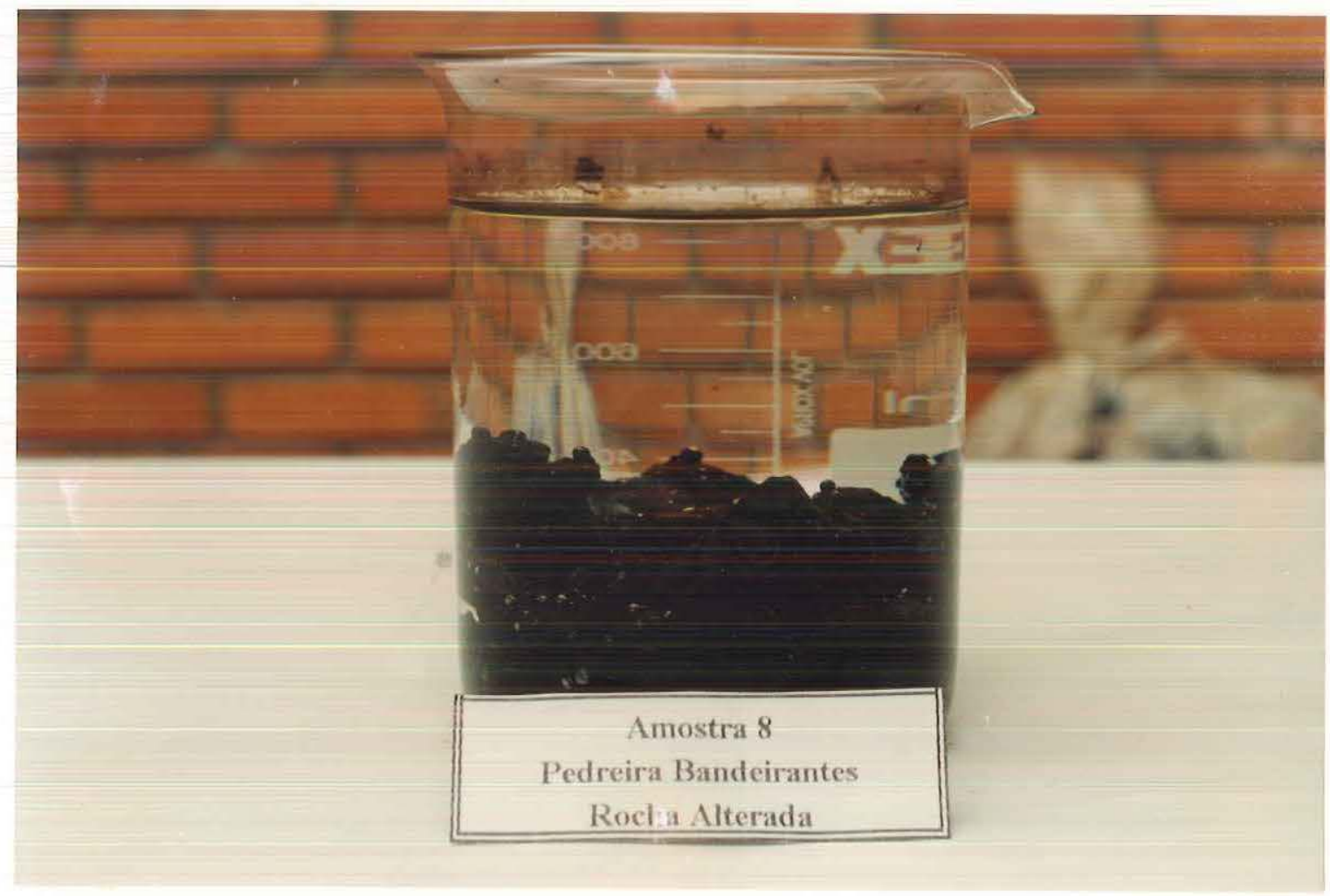

Figura IV.8 - Aspectos do ensaio de adesividade de agregado graúdo para a amostra 8 ("alterada"). 


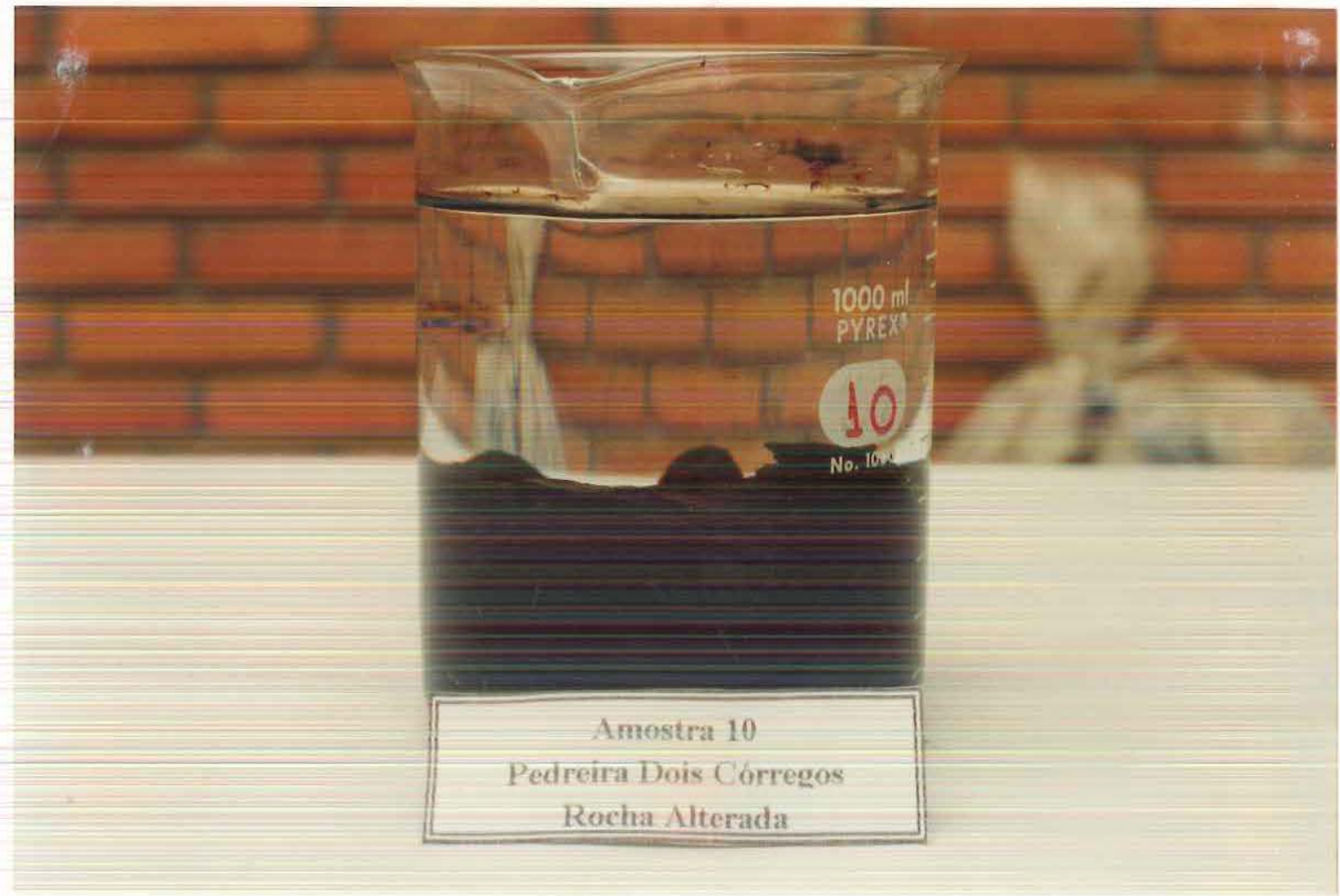

Figura IV.9 - Aspectos do ensaio de adesividade de agregado graúdo para a amostra 10 ("alterada").

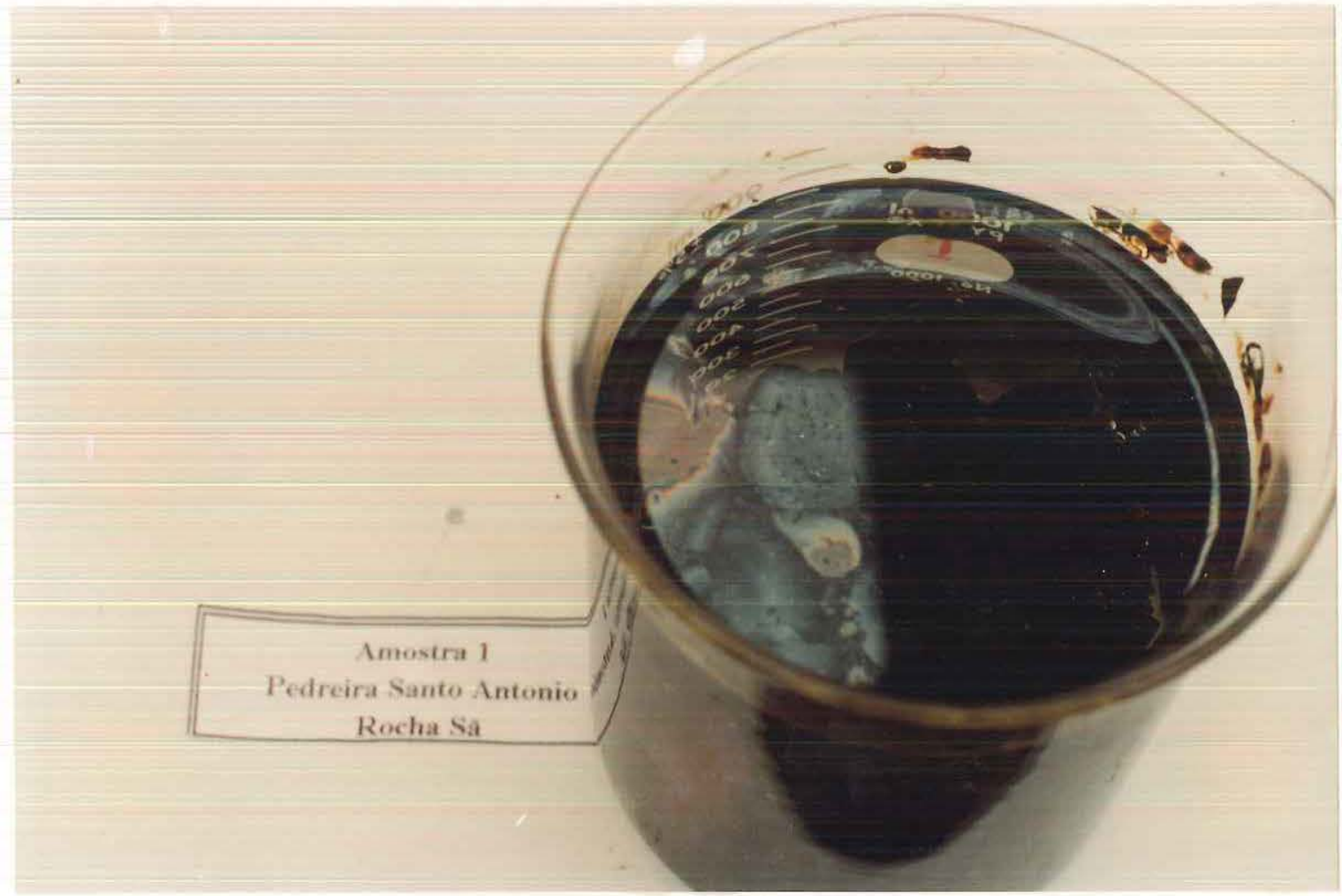

Figura IV.10 - Aspectos do ensaio de adesividade de agregado graúdo para a anostra 1 ("comercializada"), vista pela parte superior. 


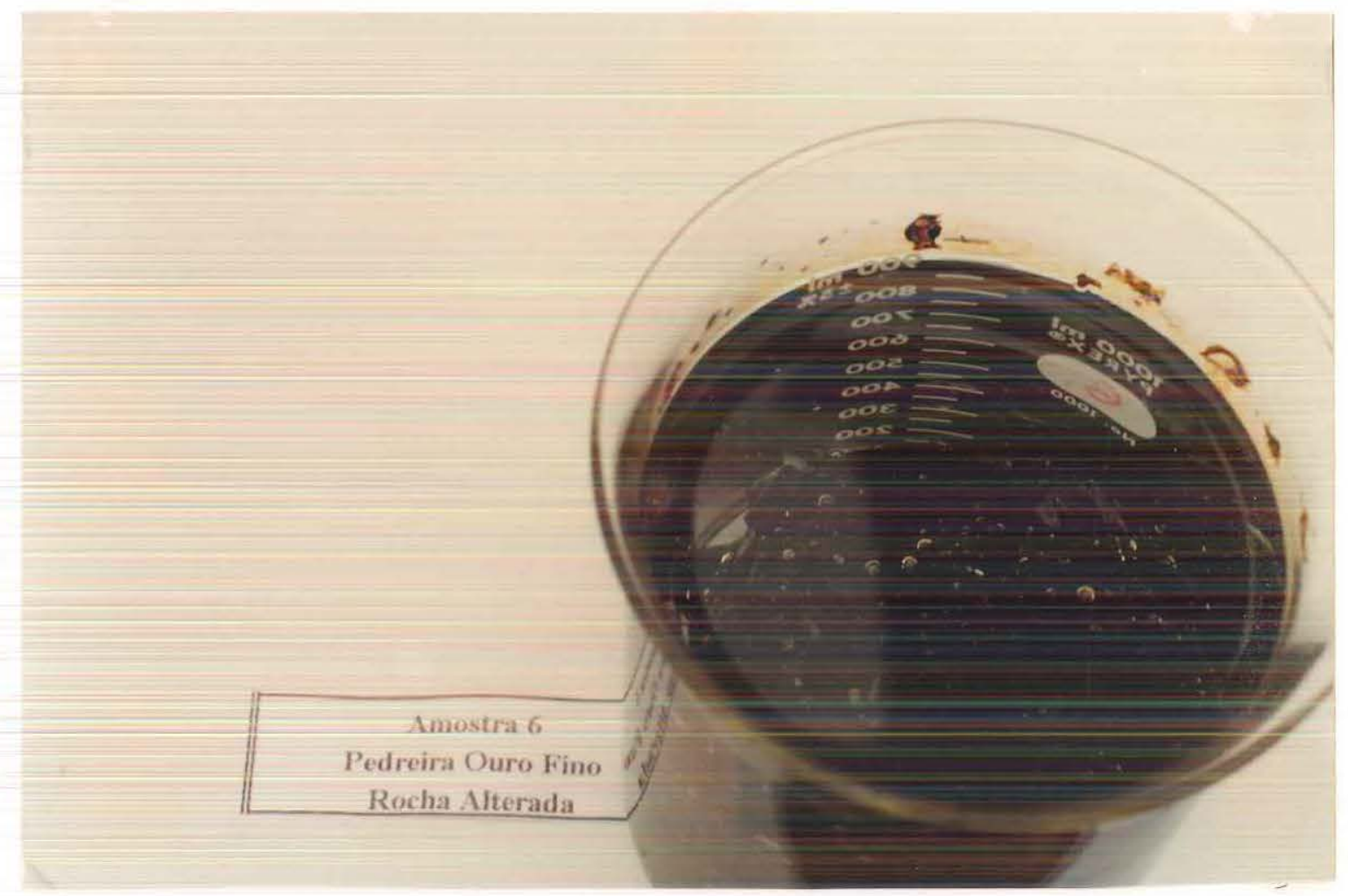

Figura IV.11 - Aspectos do ensaio de adesividade de agregado graúdo para a amostra 6 ("alterada"), vista pela parte superior.

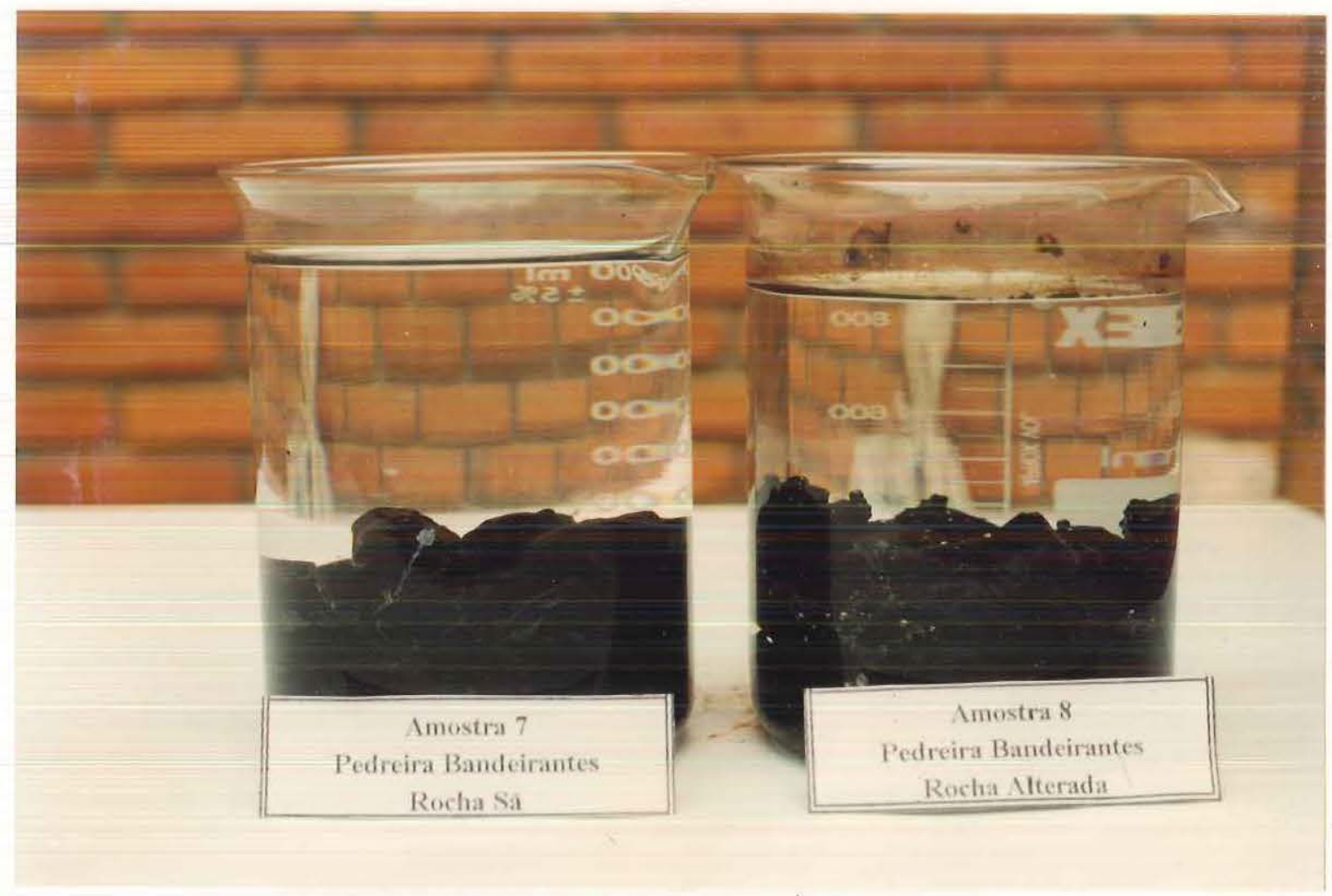

Figura IV.12 - Comparação entre a amostra 7 ("comercializada") e a amostra 8 ("alterada"), da mesma pedreira, no ensaio de adesividade de agregado graúdo. 